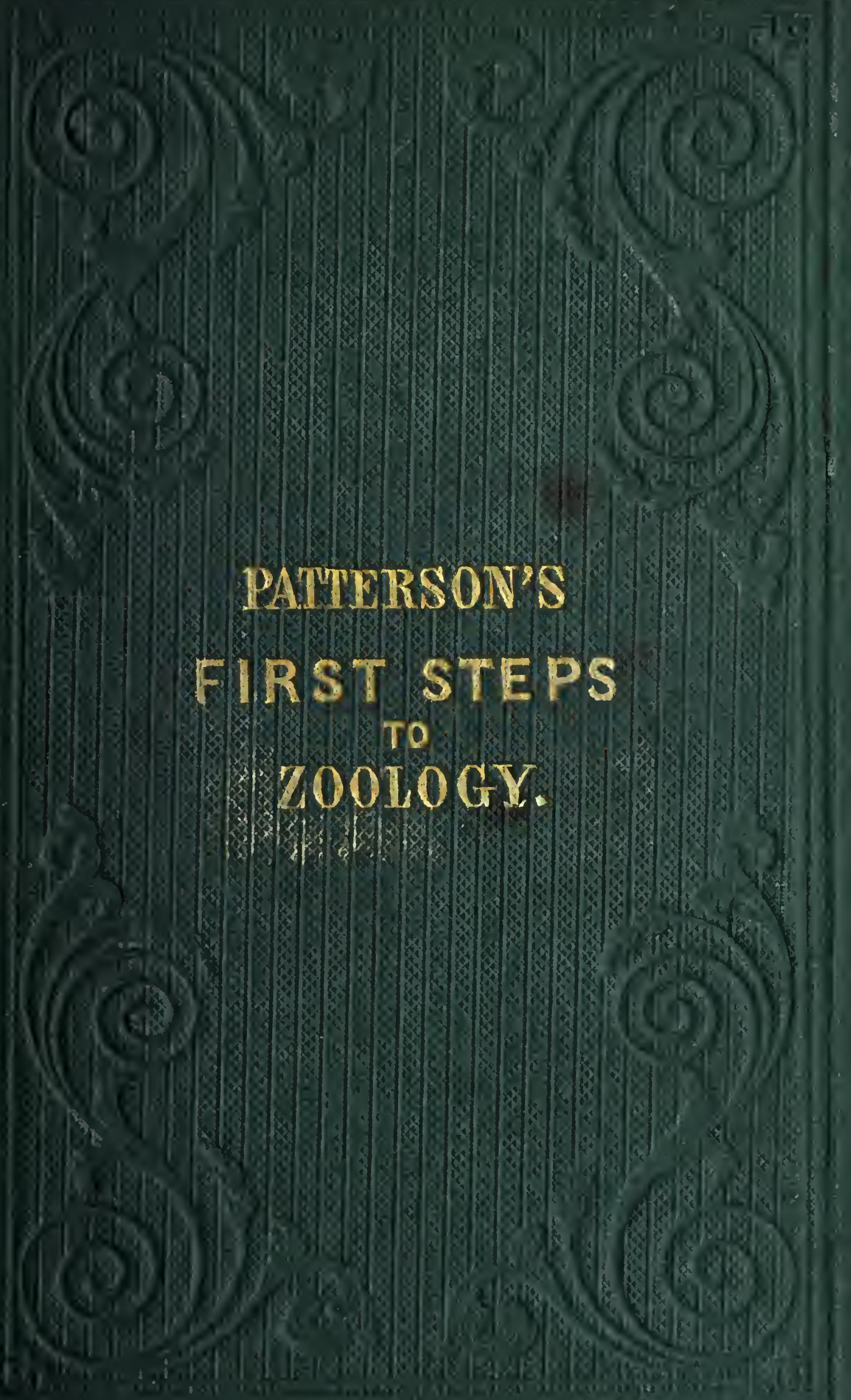




\section{STANDARD SCH0OL-B00KS,}

I'UBLISIED $\mathbf{B Y}$

\section{SIMMS\& M'INTYRE,}

\section{DONEGALI STREET, BELFAST.}

Hodges' (Dr. J. F.) Agricultural Chemistry, 14th Ed. 12mo, (c) :3 0 Jackson's Book-kecping, Sro, sheep _. . . . . . . 4 ()

Knowles's (J. Sheridan) Elocutionist, 22nd Edition, 1:2mo . : \&

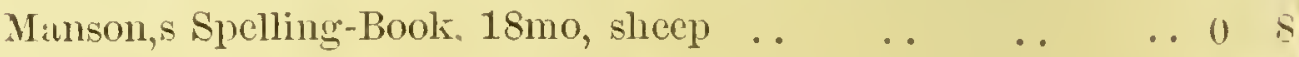

M'Crea's Pronouncing Spelling-Book, 12mo _. $\quad \ldots \quad \ldots 1$; Modem Geography Simplified, and Edition, 12mo cloth . : 0 Ilurray's Abridgnent of English Grammar, $18 m o$

First Grammar for Junior Classes, $18 \mathrm{mo}$

Patterson's (R.) Zoology for Schools, 2Sth Ed., Pt. 1, 12mo, cl. :; 0

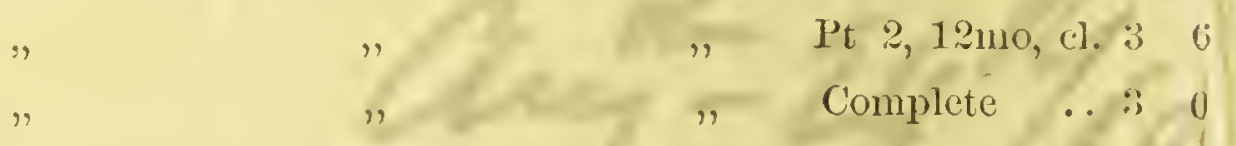

First Steps to Zoology, 3rd Ed, Pt. 1, 12mo, c.l. 1
,$\quad$ "
,$\quad$ Pt. 2, 12mo, cl. 1
$, \quad, \quad$ Complete .. (i

"Z Zoological Shects, Nos. 1 and 2 , cach _ .. 1

Huddiunan's Rudiments of Latin Grammar, 1:mo _. . 1

Thomson's (Dl• J.) Arithmetie, 45th Edition, 1:mo .. . . \& i;

Key to Arithmetic, $12 m 0$.. ‥ . . 5 !

Geography, 30th Edition, 12100 ... ... \&

Euclid, 16th Edition, Part 1, 12mo, cloth :

$"$

" " , $\quad$ Part 2, 121110, clotl :

" , $\quad$ " Complete .. .. 5

"Trigonometry, 6th Edition, sro, cloth . . 4

, Calculus, 3rd Edition, 12mo cloth _. 5 i

" Atlas, 27 maps, 4 to, half-bound .. _. \&

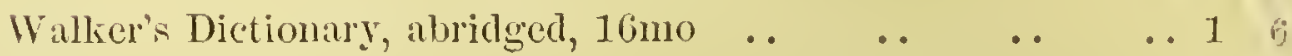






\section{F I R S S T EPS}

To

\section{$\begin{array}{llllllllllllll}Z & O & O & L & O & G & Y\end{array}$}

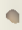

$\mathbf{B l}$

ROBER' PATIERSON, F.R.S.,

AUTHOR OF

"ZOOLOGY HOR SCHOOLS"

WITH 232 ILLUSTRATIONS.

fourty Edition.

BELFAST:

SIMMS AND M'INTYRE.

LONDON: LONGMAN \& CO, AND SIMPKIN \& CO. 1863. 
Digitized by the Internet Archive in 2018 with funding from University of Toronto 


\section{CONTEN'TS.}

Miganig of the Term Zoology, . . . . . . 1

Animats arranged in Five Primary Grouls, • . 2

PROTOZOA, OR LOWEST ANIMALS, . 3

Sux-animalcule, $\quad$ •

Microscopic Sheld-ibaring Animats, • • • . 5

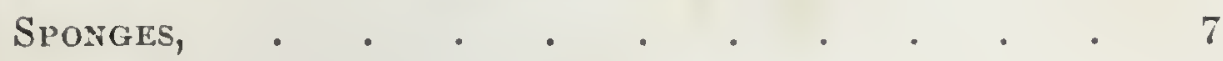

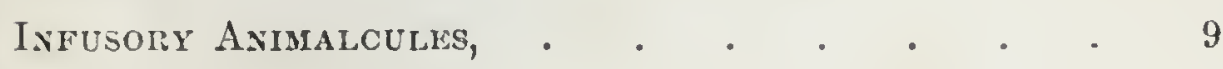

RADIATA, OR RADIATED ANIMAIS, • 13

Polypes, • . . . . . . . . . 15

SEA-JELLIES, . • • • . . . . . . . 23

STAR-Tishes, . . . . . . . . . . 30

ANNULOSA, OR RINGED ANIMALS, . 36

LeECHES and Worms, . • . . . . . 38

Ciliated Worms, . . . . . . . . 44

Ixtestinal, Worms, . . . . . . . . 45

Whiel Anmalcules, . • . . . . . . 47 
viii

CONTENTS.

PAGR

Crustacea, . . . . . . . . . . . 49

Centipedes, . . . . . . . . . . . 60

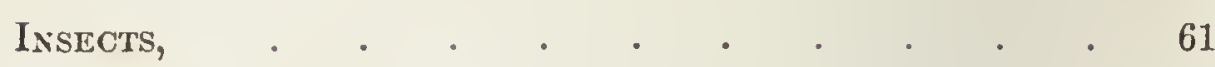

SPIDERS, . . . . . . . . . . . 94

MOLLUSCA, OR SOFT-BODIED ANIMALS, . 97

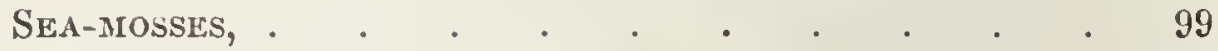

Tunicates, . . . . . . . . . . 100

LAMP-SHELLS, . . . . . . . . . . 102

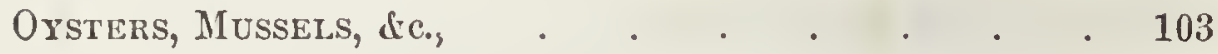

Wing-Footed Mullusis, . . . . . . . 107

Univalyes and Slugs, . . . . . . . 108

CUtTle-Fishes, . • . . . . . . 


\section{CONTENTS.}

\section{PART II.-VERTEBRATE ANIMALS.}

How Characterized-Division into Five Classes, • $\begin{array}{r}\text { Page } \\ 121\end{array}$

CLASS I.-FISHES, • • • 122

[Cartilaginous Fishes.]

Order I.-Lampreys, . . • • • . • • . 129

"II.-Sharks ANd RAYS, • • . . • . 130

"III.-Sturgeons, • • • • • • • . . 131

[Osseous Fishes.]

Order I-Globe-Fishes, . • • . • • . 132

$"$ II.-PIPE-Fishes, . • • . . . . . 132

" III.-EeLS, • • • • . . . • . 133

" IV.-Turbot, Cod, . . . . . . . 134

"V.-Herring, SAlmon, • • • . • • 136

"VI.-Red-Band Fish, John Dory, . . . . 139

CLASS II.-AMPHIBIA, • • . 142

Order I.-(Gills Permanent) Axolote, . • • • . 143

"II.-(Gills not Permanent) Frogs, Newts, . . . 143 
Order I.-Serpents, • . . . . . . . 146

$"$ II.-Lizards, . . . . . . • . 149

$" \quad$ III.-Tortoises, . . . . . . . . . 153

CLASS IV.-BIRDS, . $\quad . \quad . \quad 155$

Order I.-Birds of Prey, . . . . . . . 163

" II.-Perching Birds, • • . . . . . 171

" III.-SCRAPING Birds, . . . . . . . 184

"IV.-WAdING BIRDS, • . . . . . . 186

"V.-Swiming Birus, . • • • • • . 190

CLASS V.-QUADRUPEDS, WHALES, \&c., 195

Order I.-EChidNa, • • • . • • . . 198

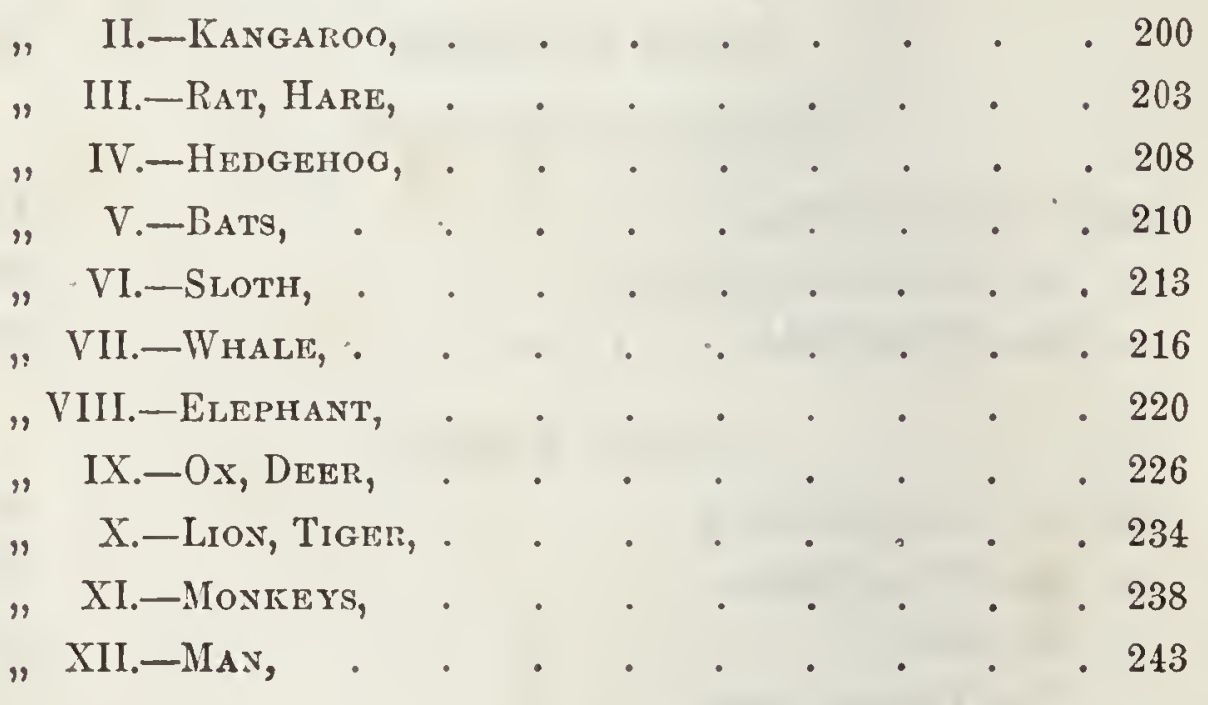




\title{
PREFACE
}

\author{
To \\ THE FOURTH EDITION.
}

The Preface to the Third Edition, published in May, 1860, contains the following paragraphs:-

"Somewhat more than eleven years have passed since the publication of the First Edition of this little book. The progress of Science during that period has been such as to demand now a revision of the text, and changes in the Classification.

"In the present Edition the size of type and shape of page differ from those of the previous impression. Much additional matter and many new woodcuts have been introduced; and the language throughout has been rendered more simple.

"To my friend, Professor J. Reay Greene, of Queen's College, Cork, I am indebted for many valuable suggestions, and for a revision which has added greatly to the accuracy of the little volume.

"R.P."

The present Edition is almost a re-print of the former, as it is not desirable to make frequent changes in the text of books intended for the use of Schools.

Belfast, 6 College Square, North, 1si Dec., 1862. 



\section{FIRST STEPS TO ZOOLOGY.}

"Look on the frame

Of this wyde universe, and therein read The endless kind of creatures, which by name Thou canst not count."-SPENCER.

Os the title-page of this little book is the word "Zoology." "What does it mean?"

It means a knowledge of animals. The science which teaches the structure, habits, and classification of animals is Zoology; the person possessed of such knowledge is a Zoologist.

When we use the word "animals" in this sense, we do not mean those only that are like the domestic quadrupeds of these countries, or the tiger and elephant of other lands, but also birds, fishes, snakes, and frogs. Nor do we stop with these; we apply the term to the snail and the oyster, to the crab and the worm, to the sea-urchin and the jelly-fish, and to those living atoms which the naked eye cannot perceive.

These creatures differ widely from each other in size, structure, and habits. Some of them are fitted to bear the cold of the Polar regions, and some to live under the scorching heat of the tropics. They people the air, 
the earth, and the waters, and in countless numbers are spread abroad over the entire surface of the globe.

All these animals it is the business of the zoologist to divide into groups, so that those may be placed together which are alike, and those may be separated, more or less remotely, which are different. The task is one that no single individual could accomplish by liis own efforts; but it has been done by the combined and successive labours of many. "In this way the entire animal kingdom has been divided into a number of great groups, distinguished from one another by peculiarities of structure.

The first of the groups contains those animals which have a skull, and a backbone composed of a number of joints or vertebrce, as in our own bodies. All such animals are termed "vertebrate," and all other animals, in which the skull and backbone are wanting, are called "invertebrate."

Four groups or sub-kingdoms were established by Baron Cuvier. To these a fifth is now added, containing the lowest forms of animal life (Protozoa). These creatures are very simple in structure, and the bodies of many of them consist chiefly of a jelly-like substance, to which the name Sarcode has been given. We have, therefore,-

I.-Vertebrated animals (Vertebrata).

II.-Soft-bodied animals (Mollusca).

III.-Annulose animals (Annulosa).

IV.-Radiated animals (Ractiata).

V.-Sarcode animals (Protozoa).

We shall begin with the most simple. 


\title{
PROTOZOA.
}

\section{SARCODE ANIMALS.}

\begin{abstract}
"Where the pool
Stands mantled o'er with green, invisible, Amid the floating verdure millions stray."-Thomson.
\end{abstract}

Such of my young readers as have ever pondered over the favourite nursery tale of Little Red RidingHood may remember the series of remarks made by the child to her supposed grandmother on her long arms, her great ears, her bright eyes, and her huge teeth; and the replies given just before the tragic ending of the tale, as to their various uses- "the better to fondle you with ;" "the better to hear with ;" "the better to gaze on you "" "the better to eat you up." From this we learn a great truth, namely, that in the higher animals the body is made up of different parts - that these parts, or, as we call them, "organs," have their several uses-each organ has one duty to perform, and does it well, whether it be hearing, seeing, grasping, biting, or digesting food when swallowed.

But in the lowly creatures among which we now find ourselves there is no such division of labour-one part or organ must do the work of several-nay, some of these creatures can seize their food without special organs for seizing, swallow it without having a mouth to put it into, and strangest of all, can digest it without a stomach! Any part of the body can at will be made to act in one or all of these ways. 
As an example, may be mentioned the Amœba, a minute creature, like a speck of jelly in appearance, found on plants growing in water. It can spread out its figure into shapes as varied as a boy could make out of a piece of soft clay or putty. Enlarged figures of two of its many forms are here shown (Fig. 1, $a, b$ ).

It slides along, wraps itself round any small animal or fragment of food it may meet with, digests it, and then casts off the remains.

Another of these animals is the Sun-animalcule. Its body (Fig. 1, c) is somewhat like a globe surrounded witlı rays or threads.
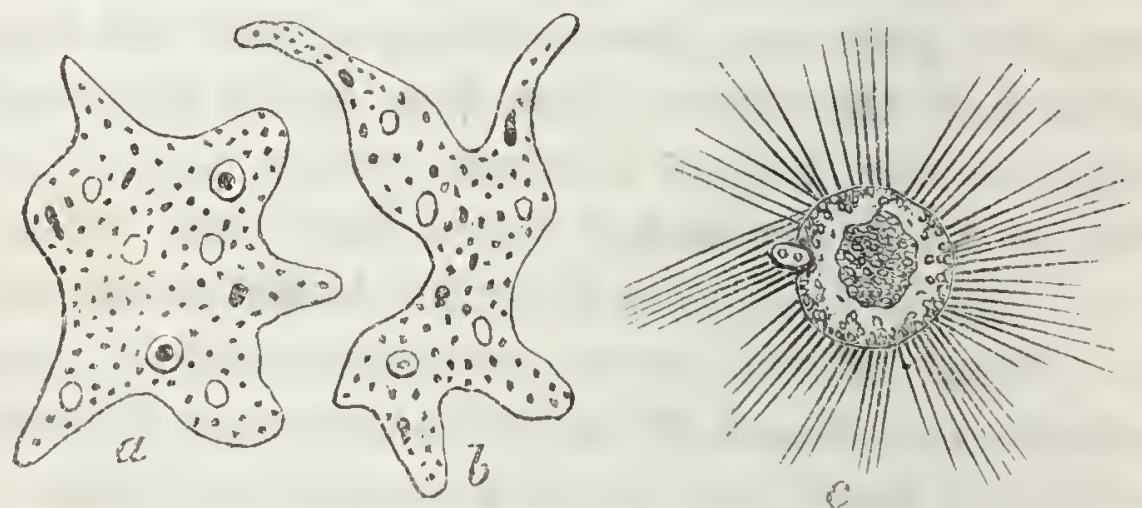

Fig. 1. - AMcebA and Sun-ANimalcule (Magnified).

If one of these rays happen to touch any of the small active animals which may come in its way, it begins to shorten, still clinging closely to the prey which it has seized. The other rays round it then bend their points together, so as to enclose the food, wlich is soon brought to the Sun-animalcule's body. Into this, by degrees, it is pushed farther and farther, and at length digested.

Both of the animals yet named are naked, that is to say, are without shells or other covering. They, and 
many other creatures belonging to the same group, have the power of pushing out from the substance of their bodies delicate gluey threads, by means of which they can move about. These threads have been compared to the fibres which we see at the roots of plants; and hence these jelly-like animals have had a term applied to them which means "root-footed" (Rhizopoda).

Many of those so named, instead of being naked, have shells formed of lime; and these, though minute, have great variety of shape, and are very beautiful. In most of them the shell has several chambers, and every one of these contains some of that jelly-like substance, which is in fact the body of the animal. These shells are pierced with very minute holes, through which the little threads are extended. This has suggested for them a scientific term which expresses the fact that the animals have shells with holes in them (Foraminifera). These shells are found in the sea only, not in fresh water. The annexed figures show

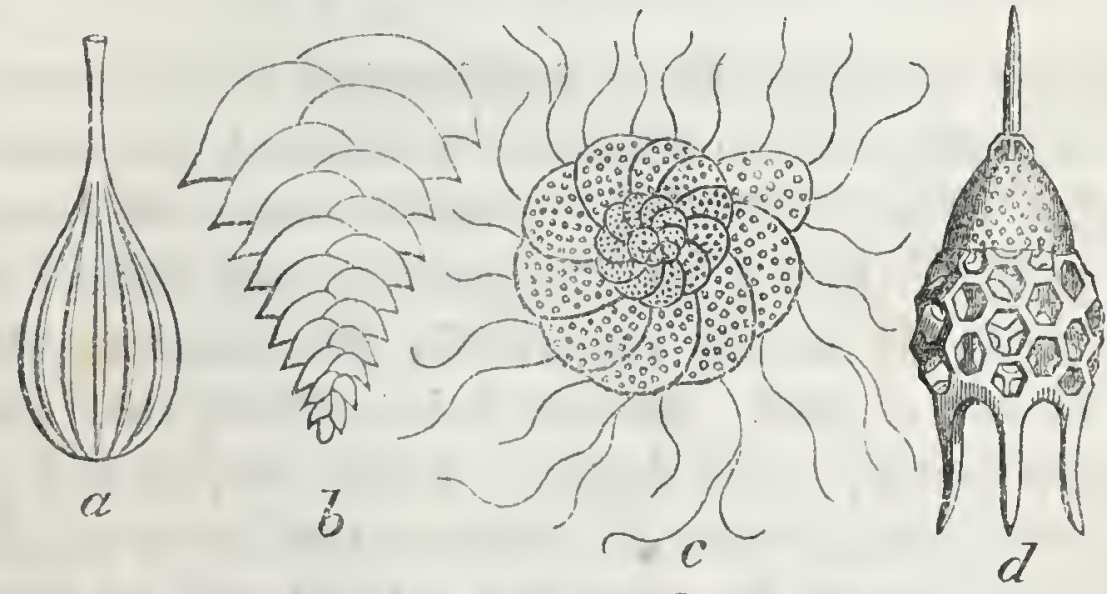

Fig 2.-Mircroscoric Suells.

some of the forms which are common round our own shores (Fig. 2, $a, b, c$ ). 
These tiny and delicate shells are widely spread throughout the ocean. Take a dried sponge, and no matter whether it has been brought from the Eastern or the Western Hemisphere, from the Bahama Isles or from Turkey, some forms of these shells will be found mixed with the sand which it contains. In the North Atlantic Ocean they cover a large part of the sea bottom. It was expected that they would have formed the quiet bed on which the Atlantic cable might have rested, and where, in course of time, it would have been covered up by the gentle but unceasing deposit of other shells of the same kind. In a fossil state these shells, though they are singly so very minute, form extensive strata in Europe, Asia, and Africa; in former years the rocks in which they occur were quarried for the building of the pyramids. We find, therefore, that these lowly beings have produced greater effects on the crust of the earth than the mightiest animals that have ever lived on its surface, whether on the land or in the water.

There are other little shell-bearing animals nearly allied in structure to those just mentioned, but smaller in size. Their shells are, if possible, even more beautiful in form (Fig. 2, d, Polycystina); and differ from the preceding in one remarkable circumstance-they are formed of flint. Strange it is to think, that those minute beings, living together in the sea, should yet be gifted with power's so different that from the seawater one draws the material to build up a house of flint, and the other, from the same sea-water, constructs its dwelling of lime. 
Spovges.-It is only of late that Sponges have been ranked as members of the animal kingdom. If we suppose a mass of naked jelly-like creatures, such as the Amobir or the Sun-animalcule (p. 4), and that this mass had the power of forming within itself harder" bodies of a certain and regular shape, we might then have some idea of the substance of a living Sponge.

If a nice soft piece of sponge had been given to a boy to be used in washing his face, he would be surprised to hear that he had been rubbing his skin with the skeleton of a dead animal; and yet nothing could be more true. The elastic fibrous substance which we call sponge is, in point of fact, the framework or skeleton. The jelly-like body, to which the name Sarcode has been given, was the flesh of the animal when living; it has all been washed away; the skeleton alone remains.

Some sponges are not suited for domestic use, because they contain a large quantity of lime or of flint. They all, lowever, do form, in clifferent parts of the living body, very small needle-shaped spikes, or, to use the more scientific term, spicula. These are not of one shape only, as the ter'm might imply; they are like spikes united at the base-or they are bent like a bowor shaped like an anchor-or remind us of a mushroom. Some idea of their variety may be formed from the annexed figures.

Seen under the microscope, they are very beautiful objects; and yet so great is the uniformity that exists amid all this variety, that most of these spicula can be referred to the kind of Sponge from which they came, and what is more remarkable, to the part where they 
were produced; for those of the flesh, the skeleton, and the surface, are different.

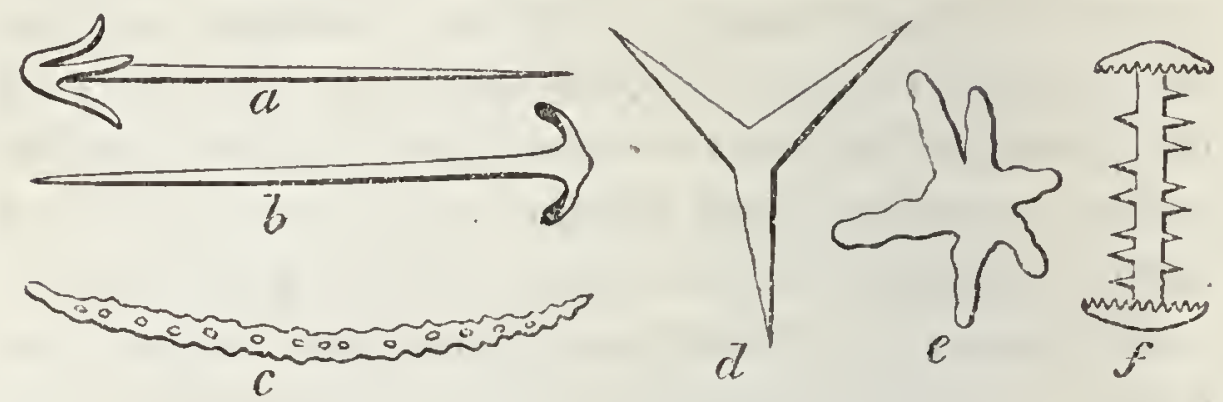

Fig. 3.-Spicula of Spoxges (Magnified).

If a very small piece of a living Sponge be put in water, and looked at under a microscope, currents are seen flowing briskly about it. The water enters into the Sponge by the small holes or pores that cover the surface; and it is driven out by the larger openings. This constant stream of water entering the body of the animal gives to it the change that is needful for health, and at the same time brings the food that is necessary for nourishment. The fluid is conveyed inwards by numerous little canals, and then collected into larger channels, which conduct to the several outlets. But never did an engineer construct canals so admirable. The circulation that he can give is poor and shuggish. It depends on his levels, his flood-gates, and the source whence he takes his supply. But the canals in the Sponge are endowerl with life, and by their untiring action urge forward the never-failing strearn.

They are not, however, at all times in full work; for the Sponge, like more exalted personages, seems occasionally to enjoy a season of quiet, more especially after a hearty meal. His command over all the canals 
is absolute; he can regulate their action, and even close them up, and open out new ones at his pleasure.

A wound given to a living Sponge is quickly healed; a part cut asunder will unite in a few hours, and that so completely that the line of union cannot be seen. If two of the same species be placed beside each other, they will unite and form one; but two of different species, even when pressed together, will not join; they continue to grow, but each will remain distinct.
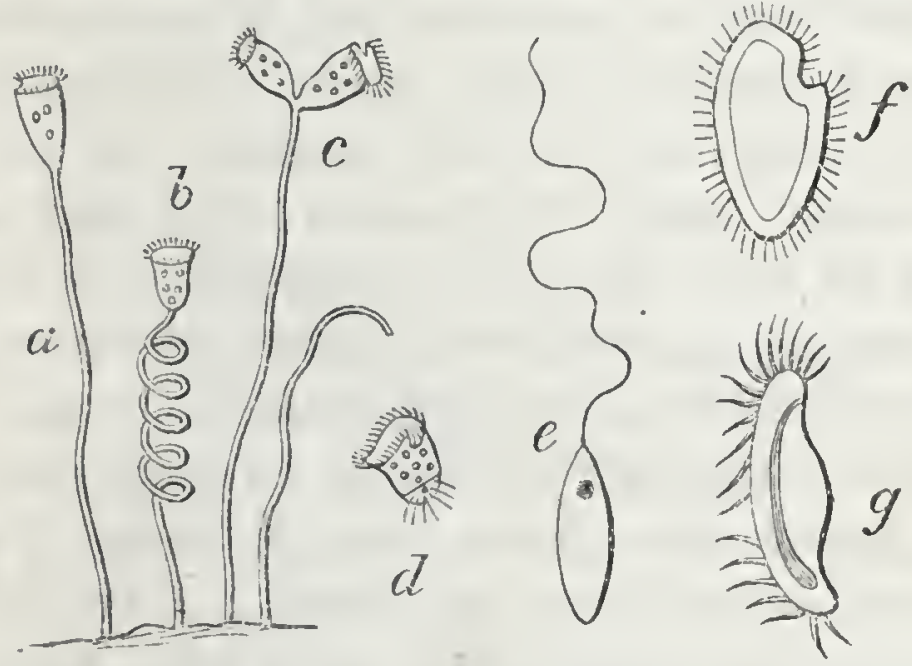

Fig. 4.-Infosorta (Magnified).

- Infusoria.-If any vegetable substance be allowed to remain for a few days in a glass of water, exposed in a window to the rays of the sun, the water will appear to the naked eye to have undergone little change. But if a drop be taken from the surface and placed under the microscope, it will exhibit such a multitude of living beings swimming about, that the spectacle cannot be looked upon for the first time without feelings of surprise. If a drop of the water containing them be placed between two pieces of glass, they will be seen swimming about with perfect ease in 
that little film of liquid, and passing and repassing without ever touching. Nor is the feeling of wonder lessened when we try to calculate their size, and form some idea of their numbers. It lias been estimated that a single drop of water may contain not only hundreds, but even many thousands of them. They differ greatly in size, but they all are possessed of one important organ, which shows an advance in the scale of animal life-a distinct mouth. The Sun-animalcule and the Sponge can take food, but have no mouths.

These animalcules (little animals) abound in infusions of animal or vegetable matters, and from this circumstance derive their name. But they are not limited to such situations: they are met with not only in stagnant pools, but in lakes and rivers, in the open sea, and even living within other animals.

It is now known that the spores or germs of some of the lowest water-plants have the power of motion, and have been mistaken for animals. It is also known that many organisms which have been described as animals belong more properly to the vegetable kingdom; as, for example, that one with a long tail (Fig. 4, e), which is common on the green surface of pools in the spring months, and under the microscope may be seen moving actively about. But after all such allowances have been made, the number of true animal Infusoria is immense. They are gifted with wonderful powers of increase, and hence they are present in every region of the earth, and almost in every drop of water on its surface.

Most of the Infusoria are active creatures, moving by means of the little hairs which arise from the 
outside of their bodies. These, though much smaller in size, are so like eye-lashes in appearance, that they have been given the name of cilia, from the Latin word cilium (an "eye-lash").

Sometimes these cilia are scattered all over the body; sometimes they are found on a part of it only. Very often a row of them is placed round the mouth.

The Infusoria vary very much in form; hence the names by which some of then are known, such as Trumpet-animalcule, Bell-animalcule, and others.

The bell-shaped Animalcule here figured (Fig. 4, $a, b, c, d)$ is a common species in pools and ditches, on the roots of water-plants. I once got a colony of them on the shell of one of the little fresh-water Snails; and I can wish my young readers no greater treat than I experienced when, for the first time, I saw one moving its graceful-looking head, stretching out its flexile stem, and then in an instant coiling it up, only to begin the whole performance over again. The fringed margirs, when in active movement, cause currents in the water, by means of which the creature is supplied with food. The one which is represented as separate from the rest (Fig. 4, d) has changed his figure, left his home circle, and is starting into the world to establish a fresh colony.

The beautiful flinty

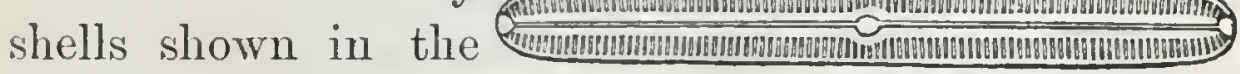
annexed figure (Fig. $5)$, and many others, were formerly believed to be produced

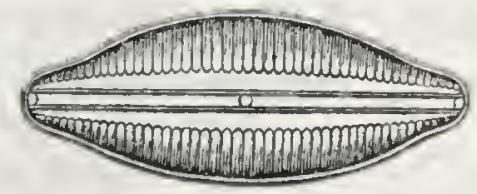

| Fig. 5.-SHells OH DIATOJIS. by Infusoria, and were therefore regarded as animal 
productions. It is now ascertained that they are truly vegetable, and as such are termed Diatoms or Diatomacece. Large deposits of them exist in many parts of the world, and are commonly, though not very correctly, spoken of as "fossil Infusoria."

Noctiluca.-There is a very minute creature, whose true place is somewhat doubtful, but which, from the simplicity of its structure, should probably be placed in this division. It is shaped like a peach, and has belonging to it what might be described as a stalk or

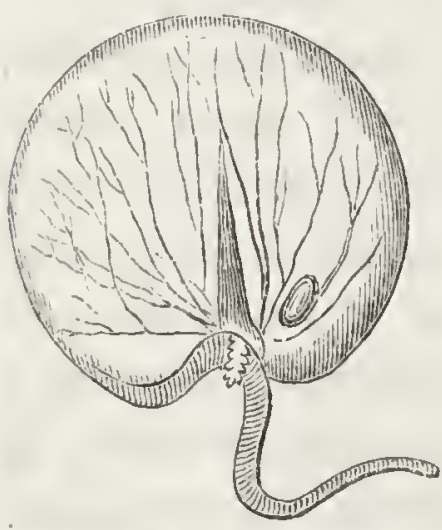

Fig. 6.-Noctiluca

(Mannified). tail (Fig. 6). It is of different sizes, but fiom 50 to 100 of them placed in a line would not measure more than an inch. It possesses a remarkable power, that of giving out light; and its name, Noctiluca, expresses this property. To this little creature we are mainly indebted for that beautiful appearance which the sea presents at night, when the prow of the passing vessel throws off a shower of sparks, and each rippling wave is bright with flashes of liquid fire. To this Sir Walter Scott has alluded in lis poem of the Lord of the Isles:

"Awaked before the rushing prow, The mimic fires of ocean glow,

Those lightnings of the wave; Wild sparkles crest the broken tides, And flashing round the vessel's sides,

With elfish lustre lave,

While, far belind, their livid light

To the dark billows of the night

A gloomy splendour gave." 


\section{RADIATA. \\ RADIATED ANIMALS.}

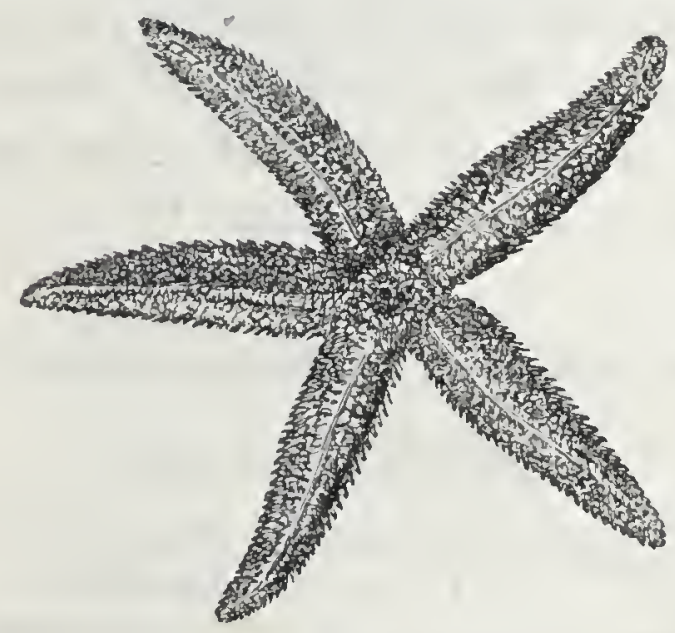

Fig. 7.-STAR-FISI.

The number of animals now arranged in this division is much less than formerly. A better knowledge of their structure and mode of increase has led to changes in their classification, some having been removed to a lower group, and some to a higher one. At present the Radiated animals consist of three classes only, namely, Polypes, Sea-jellies, and Starfishes. Each of these shows the radiated appearance in a different way. In the Polypes, or such as might be chosen as the best examples of that class, it is seen in the arrangement of the parts surrounding the mouth. 
In the Sea-jellies, which are most common on our shores, it is shown in the rays going from the centre of the upper surface to the margin or circumference. In the common Star-fishes of our coast the radiated structure appears in the general outline of the body (Fig. 7).

But it must not be supposed that each of these three classes is quite separate and apart from each of the others. A close and unexpected relationship has been discovered between some of those in the first class and some of those in the second. An'd hence these two are now very frequently included in one larger group, and spoken of by a common name.*

* The arrangement may be thus expressed:-

RADIATED ANIMALS.

Celenterata, ........ $\left\{\begin{array}{c}\text { Class I.-Polypes. } \\ n \text { II.-Sea-jellies. }\end{array}\right.$

Echinodermata, ......., , III.--Star-fishes and Sea-urchins. 


\section{Class I.-POLYPeS.}

POLYPT.

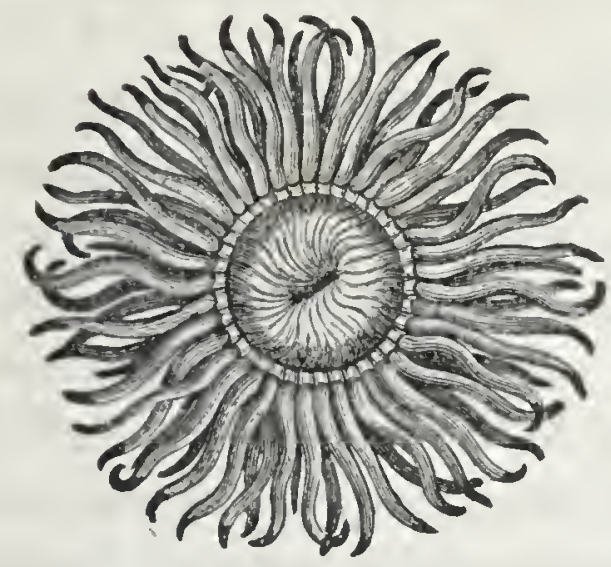

Fig. 8.-SEA-ANEMONe.

"Here, too, were living flowers,

Which, like a bud comparted,

Their purple cups contracted;

And now in open blossoms spread,

Stretched like green anthers many a seeking head."-Soutrer.

THE figure placed at the head of this chapter is that of a species of Sea-anemone when fully expanded. All animals that in structure and appearance are like the Sea-anemone may be called Polypes, as well as many others where the likeness exists, but is not noticed at first sight. In former times the Cuttle-fishes were called Polypi by the natives of Greece; and the same term was given to animals of the present class.

They differ greatly in appearance, and many Polypes, when seen for the first time, remind us of plants. Some years ago they were even mistaken for them. Afterwards they were supposed to be partly of an animal and partly of a vegetable nature. They were 
their called Zoophytes, a word derived from the Greek, and meaning "animal-plants." But there can be no doubt that all of them are true animals.

Of the Polypes to which the term Sea-anemone is applied there are several kinds; the most common has a smooth fleshy body, sometimes of a red colour, sometimes greenish, sometimes olive or brown. It may be seen on many parts of the sea-coast, fastened by one end of its body to the rock, feeling soft to the touch, and presenting when closed a very unattractive appearance. But let one of my young readers apply his fingers, and push it gently, so as not to tear the part by which it is fastened, and it can easily be taken from the rock, and placed in a vessel of sea-water. It will soon again fix itself, by what is termed the base, and the other end of the body will slowly open, and spread itself out like a beautiful flower. The appearance of the Sea-anemone in this state has suggested scientific terms which express its likeness to the Sun-flower, the Daisy, the Marigold, and other kindred blossoms. A good idea of the outline of the creature, both when closed $(a)$ and when open (b), may be formed from the annexed figures (Fig. 9).

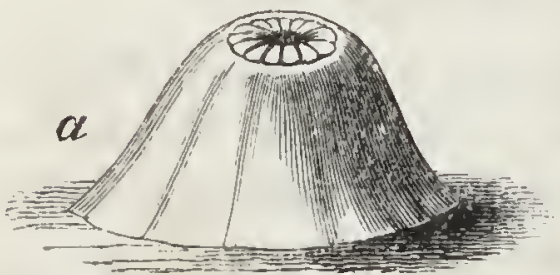

$a$, Closed.

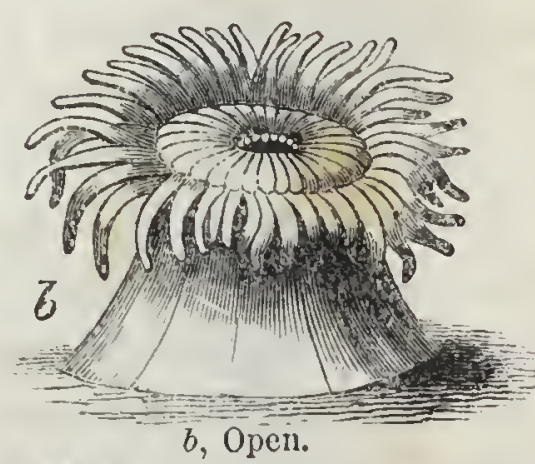

Fig. 9.-SEA-ANENONE. 
If, when the Anemone is spread out, a Periwinkle or a small piece of raw meat be dropped on what looks so like a flower, the leaf-like r"ays or "tentacles" will seize hold of the morsel, and push it into the mouth, which is in the central part. Thence it passes to the stomach, where it is speedily digested.

Though found attached to rocks, they are not fixed there for life, but can change their places at pleasure. They live upon small sea-animals of every lind, such as Crabs and Shell-fish, the hard parts being cast out by the mouth a few hours after being swallowed. Some species are used as food by man, and when boiled in sea-water, are said to have both the smell and taste of lobster.

Perhaps no fact connected with these animals is more remarkable than their power of bearing injury, and of replacing important parts when destroyed. Thus, if the tentacles be removed, others are soon formed. If the animal be cut across into two distinct portions, the upper part continues to take food as usual, though for a time unable to retain it; if diviaed in the opposite direction, two Sea-anemones are produced; and if only a part of the base be left, a perfect animal is soon raised up.

We know nothing of the usual length of life in these animals; but under favourable circumstances it would seem to be considerable. One lived in Edinburgh for the long period of thirty-one years; and twice during that period we had the good fortune to see it. In 1859 it was still healthy and vigorous, and was exhibited at the meeting of the British Association for Science held at Aberdeen in the autumn of that year. 
Its great age, and the fact that it had lived under the care of two eminent naturalists, made it be looked on with much interest.

There are many other kinds of Polypes. In one group of them, the tentacles, instead of being numerous, as in the Sea-anemone, are always eight in number, and delicately feathered along the sides, presenting, when expanded, a beautiful star-shaped figure (viz., Fig. 10).

To this group belong the Sea-pens and the Sea-fans. The surface of the Sea-fans, as usually seen in museums, consists of a hard calcareous material, that is to say, one partly composed of lime. This was originally covered with a rind or membrane, in which the Polypes lived. If the Sea-fan were formed throughout of a substance so hard and unyielding, it would be liable to be broken to pieces by the waves. The central part is, however, composed of a substance resembling horn, which bends under the force of streams and currents, and is, by this beautiful arrangement, preserved unbroken. In the Isis the stem is formed
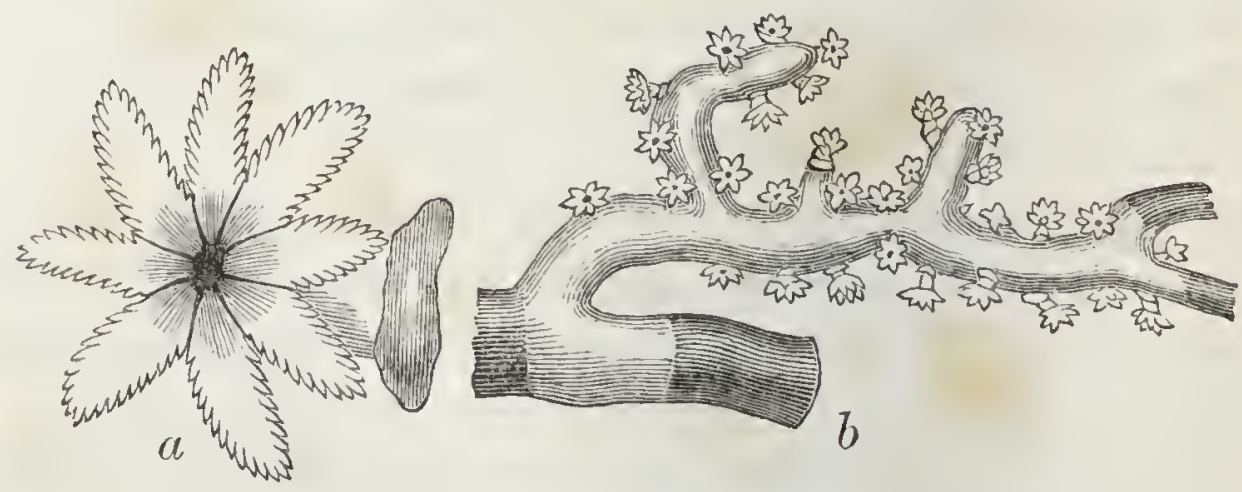

Fig. 10.-REd Coral: $a$, Polype enlarged; $b$, Branch with Polypes.

in part of a horny, and in part of a calcareous substance, arranged in alternate joints. Hence it is 
strong, and yet easily bent. When newly taken, the stem is covered with a living membrane, in which the Polypes dwell.

The common Red Coral resembles the Isis in having a living rind in which the Polypes find shelter. Inside of this is found the substance known as the Red Coral of the Mediterranean. Its growth is slow, and its short, stunted stems do not require for their protection the beautiful and effectual contrivances exhibited in the Sea-fan and the Isis. In former times, when its true nature was unknown, its branched appearance caused it, very naturally, to be regarded as a plant, and the Polypes were looked on as the blossoms. At a period still more remote Ovid gave expression in his poetry to what was then the common opinion, that the Coral was a plant, which was soft so long as it remained in the water, but hardened by being exposed to the air.

But none of these animals are perhaps so worthy of notice as the Coral-building Polypes of tropical seas (Fig. 11). The reefs formed by these little creatures are often met with of a size so vast as to excite the wonder. of all by whom they have been visited. It was formerly supposed that the reef-building Polypes worked at immense depths, and in the course of ages

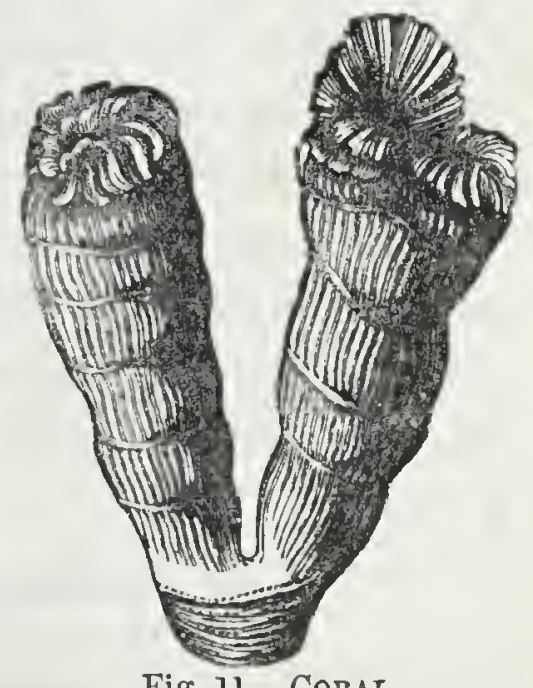

Fig. 11.-Coral. reared their pile to the surface of the water; but it has 
since been shown that this is not the case. The species most effective as builders work only at depths of not more than twenty or thirty fathoms. Yet their labours, taken in connection with geological changes, are sufficient to produce reefs in the Pacific Ocean of several hundred miles in length. These structures, it must be remembered, are not formed in an expanse of deep and tranquil waters, but in the midst of an ocean which is never at rest. The breakers, as $\mathrm{Mr}$. Darwin remarks, exceed in violence those of our temperate regions; and it is impossible to behold them without feeling a conviction that rocks of granite and quartz would ultimately yield and be demolished by such irresistible forces. Yet these coral islets stand uninjured; for here another power comes into operation. The particles of lime contained in the sea-water are separated from it by the Polypes, and united into a regular structure. Countless numbers of these busy architects are at work day and night, month after month, and we see their. soft and jellylike bodies overcoming by slow degrees the mighty power of an ocean which all the art of man would be unable to resist.

When we consider that these busy millions are silently laying the foundations of islands and continents, the future abodes of man, we must feel that the poet did not over-estimate their importance when he termed them-

"Unconscious, not unworthy instruments, By which a hand invisible was rearing A new creation in the secret deep." 
Hrdra. - The fable of the Hydra is well known: when one of its heads was cut off, two sprouted forth in its stead. Our fresh-water ponds contain a real animal which bears the same name, but surpasses the fabled monster; for every part of it is so full of life, that if cut into a dozen of pieces, each piece will become a perfect animal! Its history, as given by Trembley of Genera in 1744, is stranger than the strangest fairy tale. He found that if one Hydra were taken and pulled into the body of another they would unite and form one. If one were turned inside out, like the finger of a glove, it would live and thrive, though what had been the skin of the body was thus sucldenly clianged into the stomach, and the stomach had become the skin.

The Hydra is formd on the stem or on the lower side of the leaves of waterplants. One species has clasper's or tentacula, capable of being stretched to many times the length of its body (Fig. 12). In its contracted state it seems a little piece of jelly, not larger than the lialf of a pea; but when engaged in the capture of its food, with the tail at the surface of the water and the head underneath, it

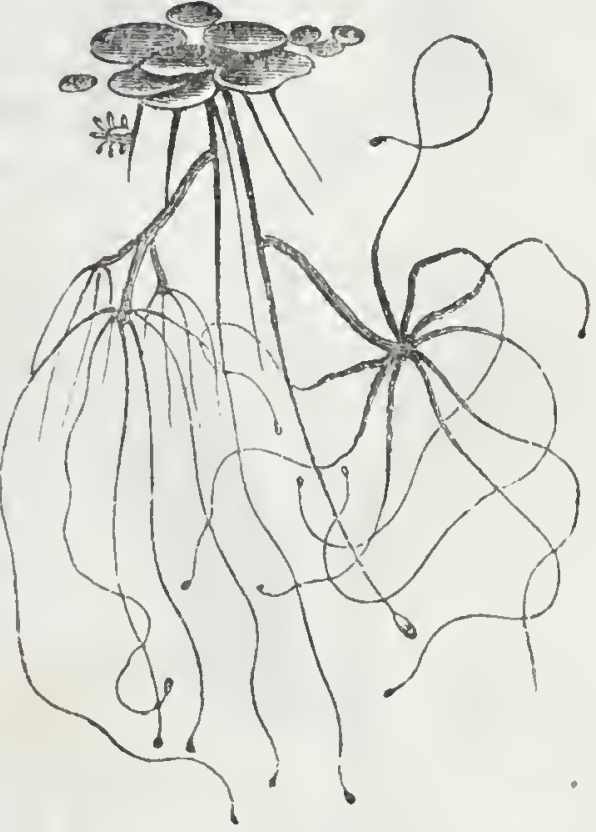

Fig. 12.-HrDras, on stems of Duck-weed. stretches its tentacula like so many fishing lines; aud there is reason to believe that it possesses the power 
of giving an electric shock, or otherwise stunning by its touch the minute inhabitants of the water.

The seas round our coasts have numerous Polypes, which in many important points are like the Hydra, and are therefore termed Hydroid Polypes. Some of these are not naked, as the Hydra is, but live in tubes, from which the Polypes project. Any one who has seen the dredge bring up from the deptl of many fathoms a number of these tubes, bent and twisted together, each surmounted by what presents the appearance of a head of scarlet flowers, will not forget the beauty of these living sea-bor'n blossoms.

Others have the power of altogether withdrawing into little cells (Fig. 13). Their common habitation

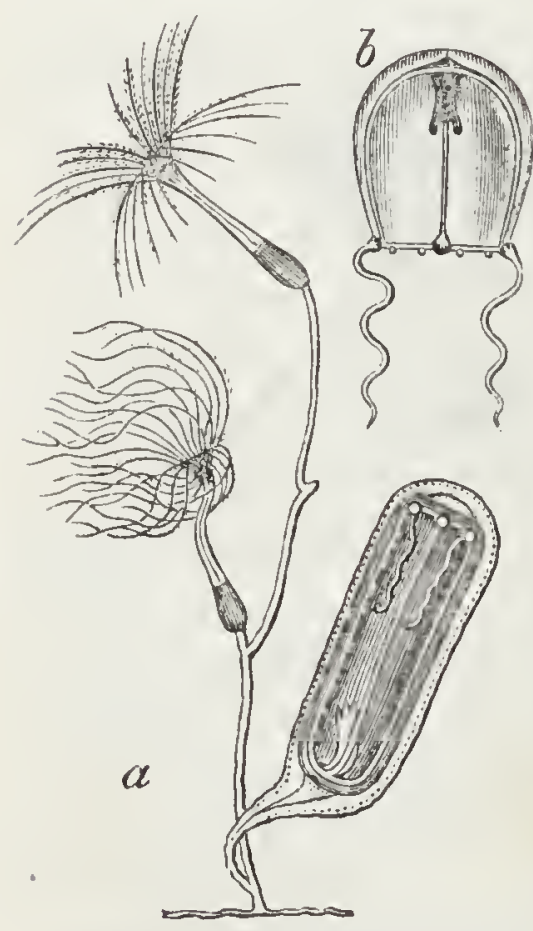

Fig. 13. - H y'drold PolyPE. presents a tree-like aspect. These are the Corallines, whose feathery tufts may be seen on the shell of the oyster or the mussel. Each cell is occupied by a Polype, and all are connected together in such a way that the food taken by one goes to the nourishment of all. So great are the number's of these Polypes that the plume-like tufts growing on a single sea-weed may bear a population greater than that of London or Pekin.

Many of these creatures have the power of giving out a beautiful light, resembling that of phosphorus. I have often taken a 
handful of them, fresh from the sea, into a dark room, and on shaking them have seen their little cells brilliantly lighted up, and shining like diamonds.*

* Explanation of Fig. 13: a shows two Polype buds and one Medusa bud; $b$ shows the Medusa bud in a free swimming condition.

Many zoologists are now disposed to regard the Hydroid Zoophytes as distinct from the Polypes properly so called, and more nearly related to the animals included in the next group (Acaléplue). To this affinity reference has been made in page 14.

\section{Class II. -SEA-JELLIES.}

ACALEPH正。

"Those living jellies which the flesh influme, Fierce as a nettle, and from that its name."-Crabre.

Those who have been in the habit of bathing in the sea, during the warm summer months, may probably have experienced the severe stinging pain caused by the touch of the long threads of the Sea-nettles or Jelly-fishes (Meduses); and if so, they will understand the reason why the old Greek naturalists gave to them a name meaning "nettles" (Acaléphce). They are found in all seas, and please the eye both by their glassy transparency and by their brilliant hues.

The Medusæe differ extremely in size. Some as large as a good-sized umbrella are occasionally thrown upon our coasts; others are about the size of peas; and 
many scarcely exceed in dimensions the head of a large pin.

Their movements are particularly easy and graceful, and are caused by the expansion and contraction of the onter margin of the umbrella-shaped surface-the animal striking the water in an opposite direction to that in which it is moving.

Some species are adorned with brilliant colours, and equal, in the richness of their hues, the brightest of our garden flowers. When from a small boat they are beheld rising and falling at pleasure, in a glassy and transparent sea, they are objects so very attractive as to excite the astonishment of the child, while they furnish matter for the thoughtful study of the naturalist.

Nor less pleasing are those of smaller size, when a dozen of them are swimming actively about in a glass of sea-water. As we gaze upon them we may natu-
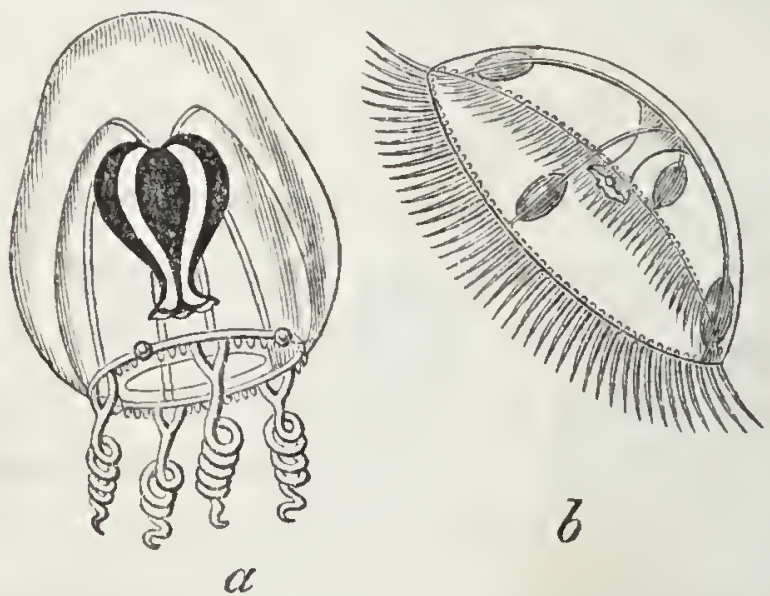

Fig. 14.-Various forms of MEDUS

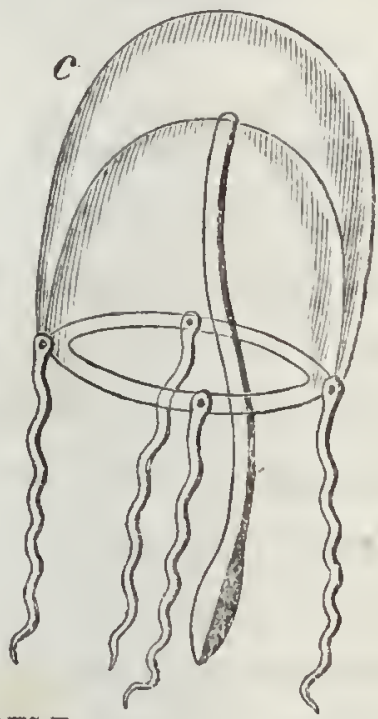

rally ask, Whence do they come? How are they produced? This is not the place to enter into such. 
questions; but we may state that in many cases they have been buds on one of the Zoophytes last mentioned. The plant-like structure rooted to the rock or the sea-weed (Fig. 13) has given origin to the freeswimming Medusa, whose movements rival in their grace those of the airy butterfly.

The group (Fig. 14) contains three figures of the smaller British Medusæ, all copied from the admirable work of Professor Edward Forbes. The species' represented in Fig. 14, c, is extremely active and graceful in its movements. The length of its body is from a quarter. to half an inch, and its long thread-like tentacula can be extended to six or eight times that measurement. That shown at $b$ is less than one quarter of an inch across, and is one of the most luminous of the tribe. The one represented at $a$ is a magnified sketch of one which has been so happily described by Forbes himself, that it would be cloing injustice to the subject not to quote his words.

"The largest objects are not always the most beautiful. Little diamonds may sparkle brighter than the monster gems of a regal crown. There is not a Medusa in all the ocean which can match for beauty with the minute creature now before us, though its smallness is such that a split pea would overtop it. Yet, small though it be, it has shape, colour, and substance so disposed, that as yet no explorer of the sea has met with another like it. It is gorgeous enough to be the diarlem of the smallest of sea-fairies, and sufficiently graceful to be the night-cap of the tiniest and prettiest of mermaidens."

The quantity of solid material contained in their 
bodies is much less than would generally be supposed. Professor Owen states that if the fluid parts of a Medusa, which may weigh two pounds, be drained away, there will remain only a thin film of membrane not exceeding thirty grains in weight.

A circumstance which shows in a striking light the large proportion of water in their bodies may here be mentioned:-A few years ago an eminent zoologist had been delivering some lectures in a seaport town in Scotland. In the course of these he noticed some of the most remarkable points in the structure and habits of the Sea-nettles. After the lecture, a farmer who had been present came forward, and inquired if he had understood him correctly as having stated that the Medusæ contained so little of solid material that they might be regarded as little else than a mass of animated sea-water? On being answered that such was the fact, he remarked that it would have saved him many a pound had he known that sooner; for he had been in the habit of employing his men and horses in carting away large quantities of Jelly-fish from the shore, and using them as manure on his farm, and he now believed they could have been of little more real use than an equal weight of sea-water. Assuming that so much as one ton weight of Medusæ, recently thrown on the beach, had been carted away in one load, it would be found that, according to the experiments of Professor Owen already mentioned, the entire quantity of solid material would be only about four pounds weight, an amount which, if compressed, the farmer might, with ease, have carried home in one of his coat pockets.

Among the animals belonging to the present class 
there are great differences, not only in size, but in general structure and appearance; and the variety that we witness around our own coasts is increased by species which are inhabitants of warmer latitudes being occasionally carried to our shores by the winds and currents of the ocean. As one example of these, the little Velella (Fig. 15) may be mentioned. Fixed

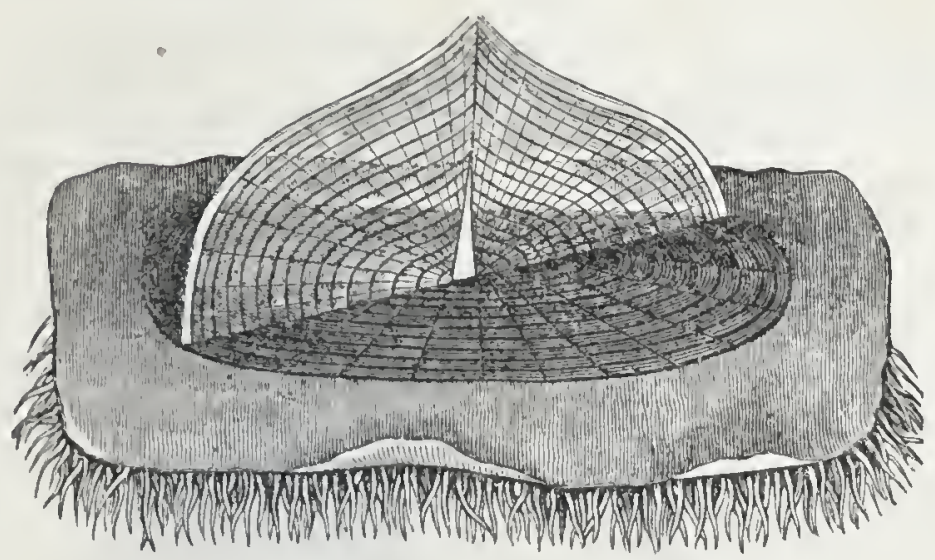

Fig. 15.-Velelia.

obliquely across a bluish oval dise, it shows a snowy crest, which has been compared to the lateen-sail of the Malay boatmen. Thus propelled, the living squadrons of this little mariner have been observed while passing the headlands of the Giant's Causeway, and the basaltic cliffs of other parts of the county Antrim. The engraving here given of one is copied from an original drawing made by Professor Allman, who remarks,"The individual who sat, or rather floated, for his likeness, was one of a fleet of countless multitudes which, in the autumn of 1836, was driven upon the coast of the county of Cork. On the subsidence of the gale, which had been blowing strongly from the southwest, the coast for miles round was strewn with the remains of the shipwrecked fleet." 
Other animals of the same group present an appearance altogether different. Their graceful forms, often not less than a yard in length, their delicate transparent bodies and brilliant colours, assume so singular and attractive an aspect that the zoologist has compared them to garlands of flowers floating near the surface of the water.

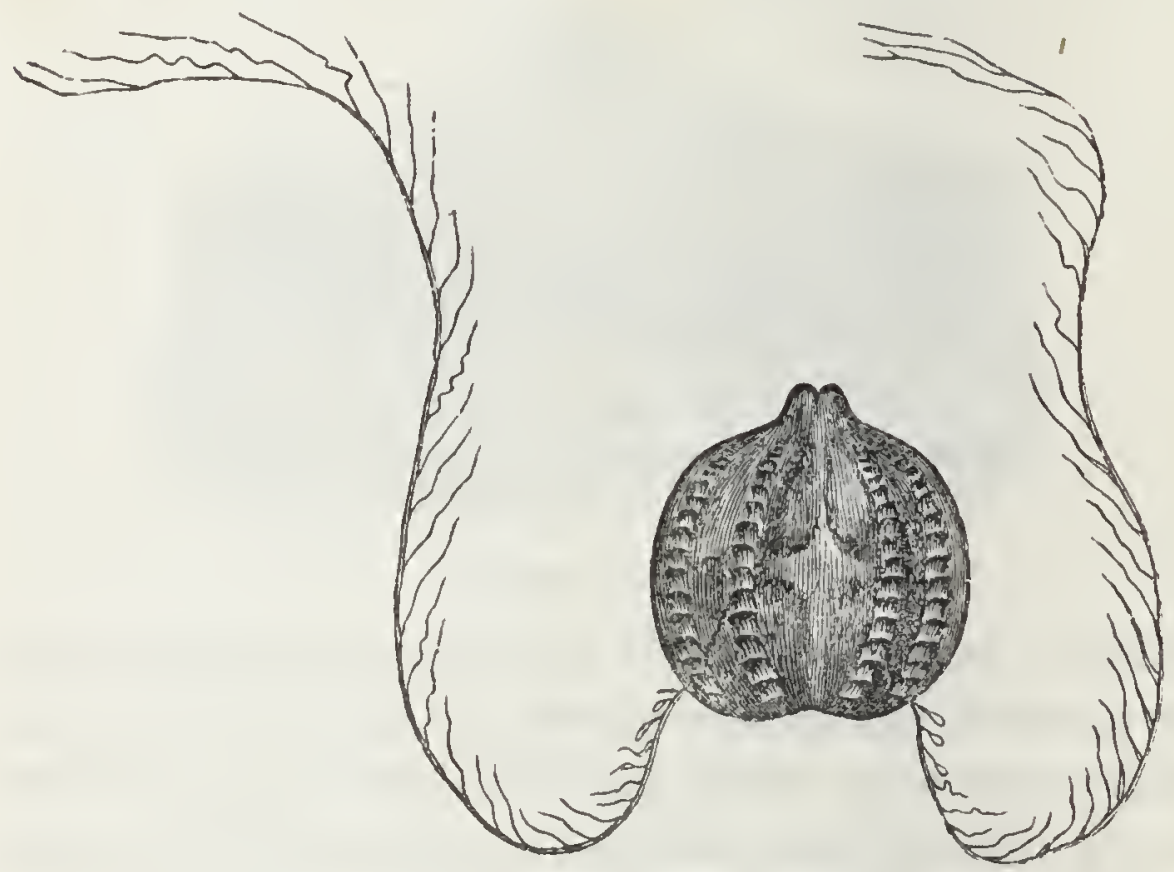

Fig. 16.-BетüE.

Belonging to a different group is a species scarcely less attractive (Fig. 16.) It is a native of our own seas, and may very easily be obtained during the fine weather of summer or autumn. If a gauze towing-net be fastened to a boat, which is rowed gently along, it is probable that, if the net be examined after a short time, there will be found among its contents some transparent bodies, differing in size, but in general about as large as a boy's marble. These are members of a family known by the name of Beröe, from one of 
the sea-nymphs of classic fable. Externally they exhibit ridges like those of a melon, and are in form not unlike an orange or an apple. If gently lifted from the net, and placed in a glass of sea-water, the animals will begin to move by means of eight bands of little paddles (cilia), which extend from the upper to the lower end of the body.

Their movements are ceaseless and ever varying. The action of the paddles on the water produces the most beautiful rainbow tints; and the variety of aspect which the little creatures present is increased by the two remarkable thread-like appendages shown in the figure, "which can in a moment be extended and displayed to their full extent, or drawn back into cavities within the body. By means of these the little Beröe can attach itself to the sides or bottom of its glassy prison, and ride, as if at anchor, moored by these singular and delicate cables.*

Many of these animals, together with the Noctiluca (Fig. 6), possess the power of giving out a beautiful phosphorescent light; and, in some of the larger Medusæ, this is of such extreme brightness that they have been compared to balls of fire in the water. We have shown, at Fig. 14, b, a magnified figure of one of the smaller light-giving Medusæ of the British seas.

* It has been suggested by some naturalists that the Beröes ought not to be assuciated with the Sea-jellies, but rather with the true Polypes, which, in internal st:ucture, they much resemble. 


\title{
Class III. - STAR-FISHES.
}

\author{
ECHINODERMITA.
}

"As there are stars in the sky, so there are stars in the sea."-Lrvk.

THIs class contains all those rayed animals with a hard or leather-like covering, and which, in some species, have prickles like those of the Hedgehog. They exhibit, in many respects, an entire contrast to those we have just been considering.

In this group are to be found many animals that are extremely unlike in external appearance. Some, like the Star-fish, have arms radiating from a common centre; some, like the Sea-urchin, are globular, and have no arms; and some are so worm-like that they have been mistaken for Worms.

Of this class there are five principal divisions. Three of these are commonly known as Star-fishes: the others are termed Sea-urchins and Sea-cucumbers.

Feather-stars and Stone-Lilies.-The first group of Star-fishes includes those animals which, in a fossil state, are known as "Stone-lilies." These beautiful animals were in former periods among the most numerous of the ocean's inhabitants; so numerous that their skeletons form great tracts of the existing dry land. Now they are rare, and in European seas are represented by the young of a species which in this state 
measures only about three-quarters of an inch in length, and is like some of the Polypes we have been considering (Fig. 17). It is, in fact, a very small feathery-looking Star-fish, mounted on a stalk; and wonderful are the changes it undergoes. At a certain period the little animal separates from the stem, and swims freely about. It gradually increases in size, is known as the "Rosy Feather-star," and gives origin to a race of descendints, each of which, in its young state, is fixed like a plant or a Coralline, and when more mature becomes free, and moves about like the parent.

Brittle - stars. - The second group consists of

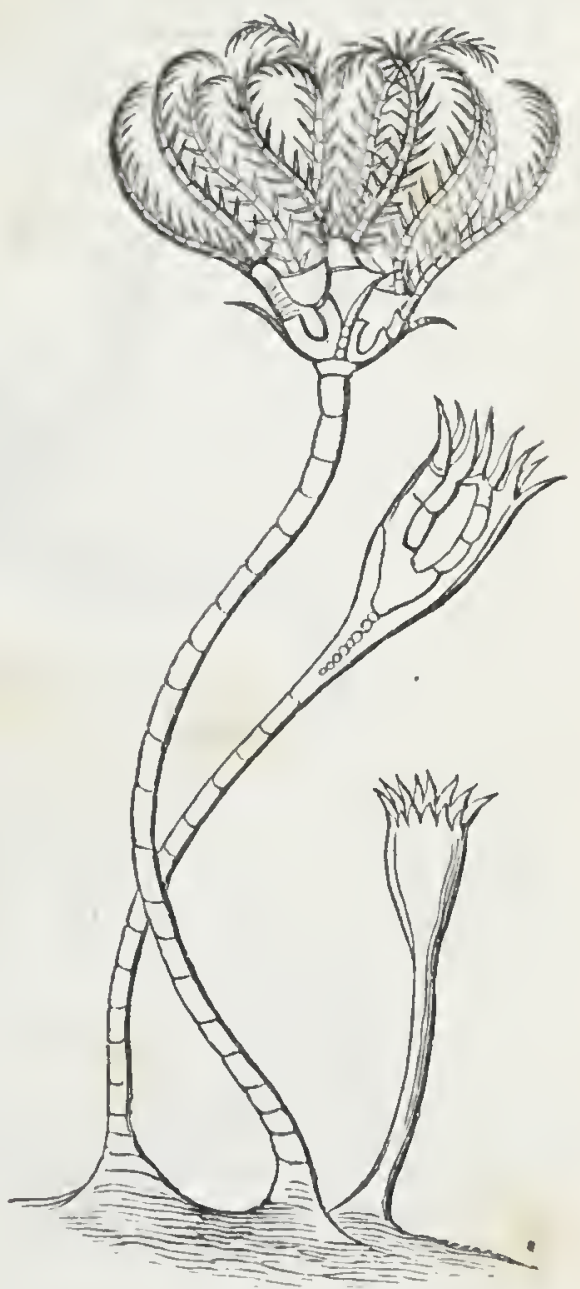
those Star-fishes which have Fig. 17.-Polype state of the Featuera roundish central body, STAR (Magnified). furnished with five long arms, not unlike the tails of serpents. These arms are placed round the body, and are easily separated from it at the pleasure of the animal; from which circumstance the English name of "Brittle-star's" has been bestowed upon the tribe (Fig. 18). Its members differ very much in size and appearance. Some of them measure as much as sixteen inches in 
diameter; other's are so small that a score or two of them might be displayed on an ordinary visiting card. Professor For bes, in speaking of a spine-covered species,

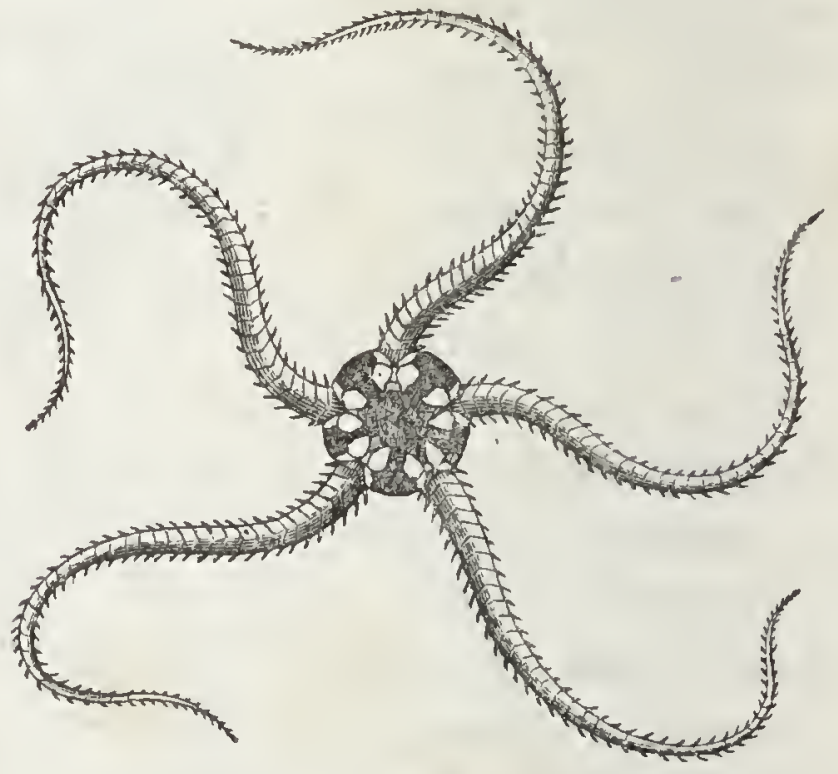

Fig. 18.-BRITTLE-STAR.

remarks,_- " Of all our native Brittle-stars this is the most common and the most variable. It is also one of the handsomest, presenting every variety of variegation, and the most splendid displays of vivid hues arranged in beautiful patterns. It is the most brittle of all Brittle-stars, separating itself into pieces with wonderful quickness and ease. Touch it, and it flings away an arm; hold it, and in a moment not an arm remains attached to the body."

True Star-fishes. - To this division the common Cross-fish or "Five fingers" belongs (Fig. 7). Each of its arms has deep grooves or hollows along its entire length, through which the animal can extend a multitude of little suckers, or tubes, which serve as feet to carry it along, and help it to seize and master its prey. No one can form a true idea of the beauty and singularity 
of these organs, who has not seen them in action. Let any one, when opportunity offer's, pick up from the beach one of these animals, which, as it lies upon the sand, left by the retiring waves, appears so utterly helpless and incapable of movement; let him place it in a large glass jar, filled with sea-water. Slowly he perceives its arms expand to their full stretch, hundreds of feet are stretched out, and each one, as if possessed of independent action, fixes itself to the vessel as the animal begins to march. The numerous suckers are soon all at work, some remaining fixed, while others change their position; and thus the Star-fish, by an easy, regular, gliding motion, changes its place along the bottom, or climbs the smooth sides of the glass in which it is confined.

The annexed figure represents one of the Star-fishes belonging to this group. It is one of our native species, but instead of being shown in the aspect it usually exhibits, it is depicted in one which gives a new interest to this humble creature. The female Cribella, for such is

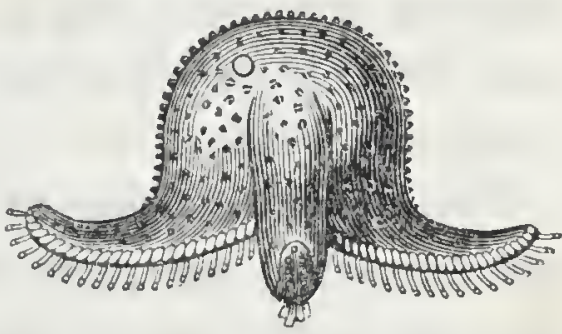

Fig. 18. - Exed Cribellad. its name, has bent her body over her eggs, so as to make it serve as a pouch for their protection.

SEA-URChins.-The members of the fourth division, that of the Sea-urchins, are furnished with spines; and from the resemblance in this respect to the Hedgehog, the family takes its scientific name-Echinida (Fig. 19). Here the arms have disappeared, and the form has become more or less rounded, according to 
the species. The spines do not grow from the "shell," as it is commonly termed, as thorns do on the branches of the common hawthorn. They are attached to little

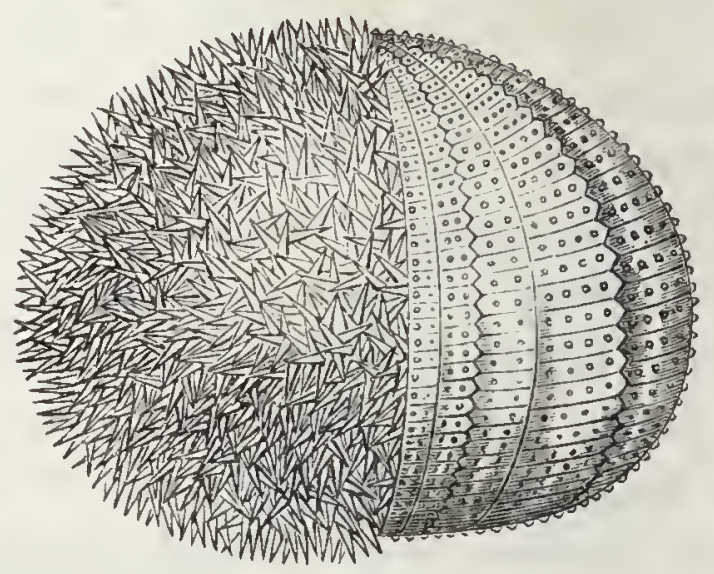

Fig. 19.-SEA- URCHIN.

round knobs, and move upon them in the manner of so many ball-and-socket joints. The Sea-urchins are also furnished with suckers, like those described in the Star-fishes; and by the joint action of their spines and suckers, they can move in any direction they please, or can moor themselves to the surface of rocks underneath the water.

The outer covering or "shell" of the Sea-urchin is not formed of one piece, as the name would lead us to suppose, but of many pieces fitted together, every one of which is made to enlarge with the growth of the animal. Those pieces are shown in the above figure, the spines having been removed for that purpose from the right side. It is impossible for a thoughtful mind to contemplate the structure of the shell, and consider the movements of the spines and suckers, without at once feeling the conviction that in them we are permitted to behold a portion of "the works of the Lord, and his wonders in the deep." 
Sen-cucumbers.-The individuals of the fifth group are known by the English name of Sea-cucumbers (Fig. 20 ), a term which gives some idea of their general form.

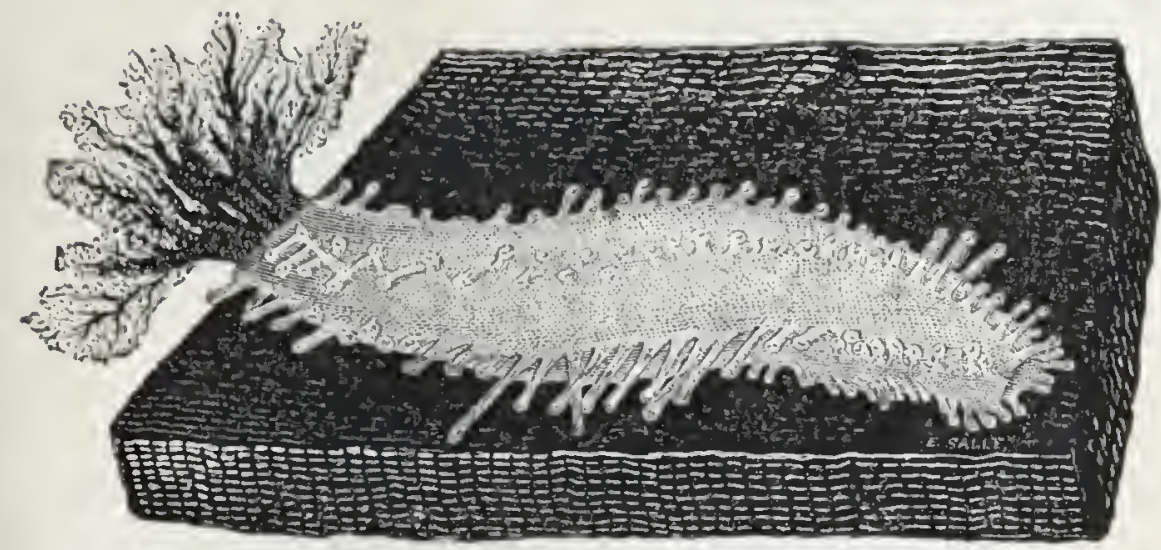

Fig. 20.-Holothuria.

On them the spines have disappeared; but, as the covering of the body is soft, they can move by the extension or contraction of its parts, as worms do; and, like the Sea-urchins, they continue to employ the aid of suckers. It is an animal of this kind which the Malays of the Oriental Isles seek so diligently for the supply of the China market, where it obtains a good price when well preserved. It is enployed by the Chinese in the preparation of soups, in common with a kind of sea-weed, sharks' fins, edible birds' nests, and other materials, affording much jelly.

Any one who has here had his attention called to the Star-fishes, the Sea-urchins, and other beings that form the present Class, will be better prepared for observing them, whether on the coast or when brought up from the sea-bottom in the dredge. And he will look with increased interest on similar forms converted into stone, and embedded in the solid masses of our cliffs and quarries. 


\section{ANNULOSA.}

\section{RINGED ANTMALS.}

"Whatever" creeps the ground,

Insect or worm; those waved their limber fans

For wings, and smallest lineaments exact

In all the liveries deck'd of summer's pride,

With spots of gold and purple, azure and green;

These as a line their long dimensions drew,

Streaking the ground with sinuous trace."-MrLtos.

I'HE animals belonging to this great division present an appearance altogether different from most of those which we have alreadly noticed. The same is true

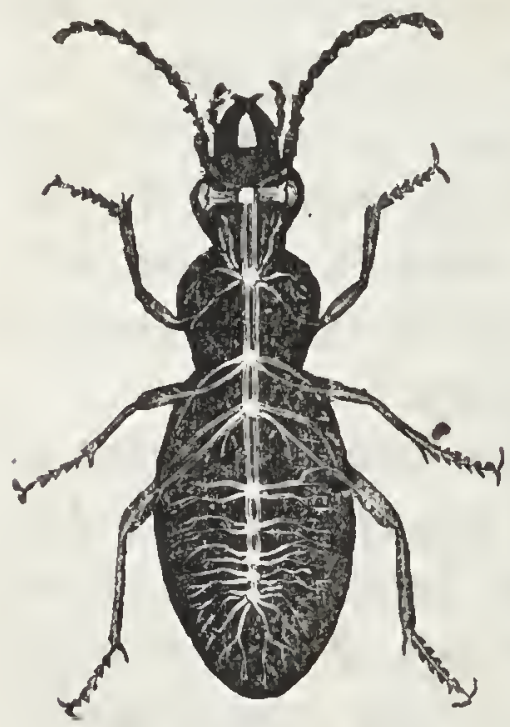

Fïg. 21. -Nervous Ststems OF A BEETLE. of their internal structure, and is well seen in the arrangement of the nerves. These, as in the annexed figure, often occur in the form of a double thread, extending along the body, and joined by little knots at certain distances.

In most of these creatures the body would appear to be made up of a number of distinct rings or joints-a fact which is implied in the scientific term at the head of this Sub-kingdom. But in others such an arrangement is not very clearly seen. 
And hence it has been proposed to separate (under the name of Articulata) those classes of ringed animals in which the jointed structure is best manifested, from those other members of the group in which it is shown with less distinctness. The following table exhibits this classification :-

\section{ANNULOSA.}

Grour 1.

(Annuloida or Ring-like Animals.)

Class 1.-Annelida, ............... Leeches, Earth-worms, foc.

"2.-Turbellaria, .......... Ciliated Worms.

" 3.-Eхтоzод,................Intestinal Wornis.

" 4.-Rotifera,............. Wheel Animalcules.

\section{GrotP 2.}

(Articulata or Jointed Animals.).

Class 5.-Crustacea, ............Crabs, Lobsters, $\&$ c. .

" 6.-Mrriapoda, ...........Centipedes, fc.

$" \quad$ 7.-Insecta,.................Beetles, Butterflies, gic.

" 8.--Arachinida, ...........Scorpions, spiders, fic.

By Cuvier the word Articulata was used in a wider sense, to denote the entire group of ringed animals. By some modern naturalists it is still employed with the same signification.

* The word articulus means a joint-annulus a ring. 
Class I.-LEECHES, EARTH-WORMS, \&c.

\section{ANNELIDA.}

Is the Leech or Earth-worm the body seems composed of a number of little rings, and hence the Latin word Annellus, which signifies a little ring, suggests a suitable term for this class of animals.

The medicinal Leech and the common Horse-leech of our ponds are so well known that every one must,

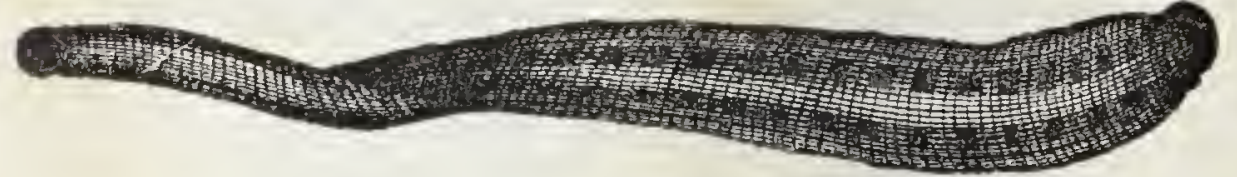

Fig. 22, -LEECH.

at some period or other, have noticed that either extremity of the body can, at the will of the animal, be used as a sucker, and thus converted into a support, or point to hold on by. Leeches are of many species; but these peculiar discs or suckers may be regarded as "the badge of all the tribe."

The medicinal Leech is not a native of Ireland; it is found in some parts of Britain, but is now becoming very rare. It is still seen in the lakes of Cumberland, but even there it is rapidly disappearing. This fact is mentioned by Wordsworth in a stanza, which notices at the same time the manner in which they are collected:-

"He with a smile did then his words repeat;

And said, that, gathering leeches, far and wide

He travelled; stirring thus about his feet

The waters of the pools where they abide.

Once I could meet with them on every side;

But they have dwindled long by slow decay;

Iet still I persevere, and find them where I may." 
The supply of Leeches used in these countries is derived from France, Sweden, Poland, Hungary, the frontier's of Russia, and Turkey; and the great extent of the trade thus carried on may be judged of from the fact, that four only of the priucipal dealers in Loudon imported, a few year's ago, 7,200,000 annually.

The winter is passed by our common Horse-leech in a state of torpidity, in the mud at the bottom of the ponds or ditches in which it lives.

In this country we usually experience no personal annoyance from Leeches; but we are told by Sir Emerson Tennent, that "of all the plagues which beset the traveller in the rising grounds of Ceylon, the most detested are the land Leeches." * In size they are about an inch in length, and when not filled with blood, are as fine as a common knitting-needle. In moving they have the power of planting one end of the body on the earth, and raising the other straight upwards, to watch for their victim. And no sooner does a traveller approach, than they may be seen among the grass and fallen leaves preparing for their attack. They approach rapidly, fixing one end firmly and arching the other forwards, till by successive advances they can lay hold of the traveller's foot, and climb up his dress in search of an opening to enter. Their size is so very small, and the wound they make so entirely unfelt, that their attack is only made known by the trickling of the blood, or the chill feeling of the Leech, when it begins to hang heavily on the skin, when swollen by its feast. "Horses are driven wild by

- Ceylon; by Sir James Emerson Tennent. Longman \& Co., 1859. 
them, and stamp the ground in fury, to shake them from their fetlocks, to which they hang in bloody tassels. The bare legs of the palanquin-bearers and coolies are a favourite resort; and their hands being too much engaged to be spared to pull them off, the Leeches hang like bunches of grapes round their ankles; and I have seen the blood literally flowing over the edge of a European's shoe from their innumerable bites."

The Earth-worms represent another tribe. They are without discs or suckers, such as those of the Leeches, but a contrivance of a different kind may be observed. The rings of which their body is composed are no longer perfectly smooth, but are furnished with small bristles or hooks. These, as the creature pushes its way, catch upon the soil, and form fixed points of support, by which the Worm is enabled to maintain its place while drawing forward the remaining parts of the body. Earth-worms move but little abroad during the day-time, except when disturbed.

The mouth of our common Earth-worm is without teeth. The food consists of the decaying particles of

- animal and vegetable matter contained in the soil, with which the Worm gorges itself; and thus, instead of being dissolved and lost, they become the means of supporting animal life. The results do not however stop here, but extend to birds and fishes, and even to man himself. This did not escape the observation of White of Selbourne, who justly remarks :-

"The most insignificant insects and reptiles are of much more consequence, and have much more influence in the economy of nature, than the incurious are aware 
of ; and are mighty in their effect, from their minuteness, which renders them less an object of attention, and from their numbers and fecundity. Earth-worms, though in appearance a small and despicable link in the chain of nature, yet, if lost, would make a lamentable chasm. For, to say nothing of half the birds, and some quadrupeds, which are almost entirely supported by them, Worms seem to be the great promoters of vegetation, which would proceed but lamely without them, by boring, perforating, and loosening the soil, and rendering it pervious to rains and fibres of plants-by drawing straws and stalks of leaves and twigs into it-and most of all, by throwing up such infinite numbers of lumps of earth called wormcasts, which being their excrement, is a fine manure for grain and grass."

Breathing, both in the Leech and in the Earth-worm, is carried on by means of pores and internal sacs. In the "Lobworm," or "Lug" of fishermen (Fig. 23) -a worm belonging to another group-a portion of the body is furnished with little tufts, and the blood-like fluid brought to them is purified by coming into contact with the air which the sea-water contains.

In the next tribe of Annelids a

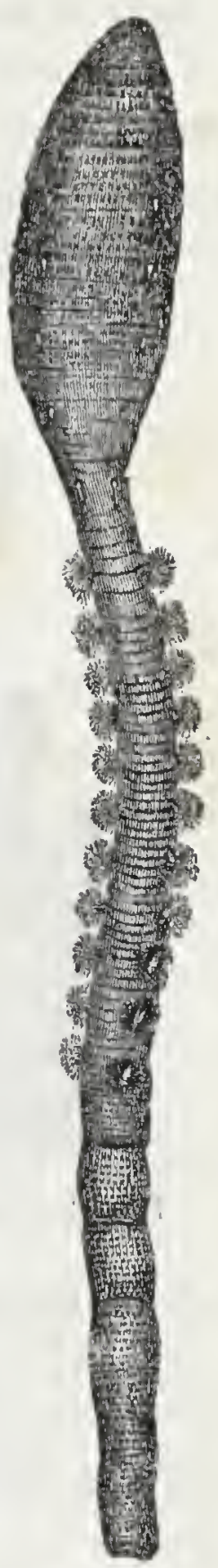

Fig. 23.

Arenicola. change in these organs is exhibited,-one admirably fitted to their habits and modes of life. All the 
individuals of this group dwell in tubes, consisting either of shelly matter, secreted from their own bodies, or of particles of sand and gravel, glued together, to serve as a habitation. Under these altered circumstances, the only place to which the pure air contained in the sea-water could freely have access would be that near to the entrance of the

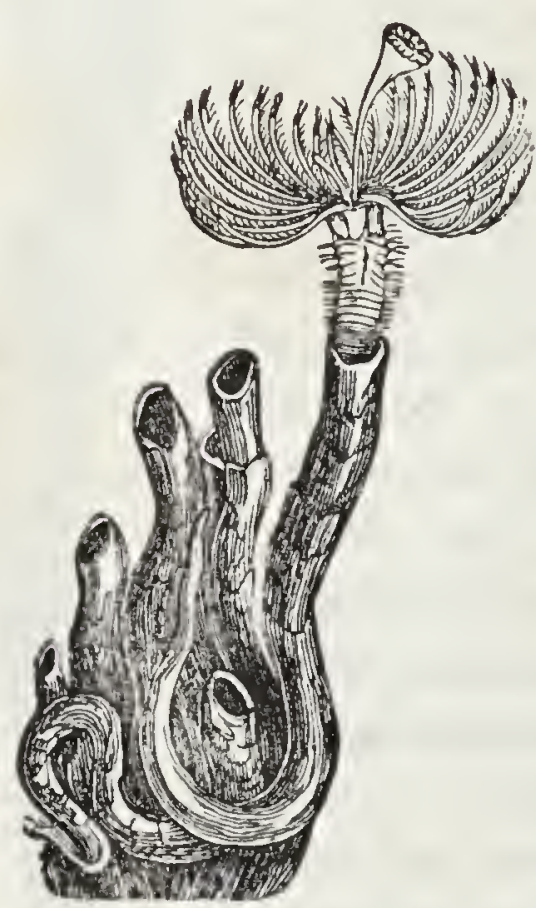

Fig. 24.-Group of Serptla: tubes; and here, accordingly, we find the breathing organs are arranged, often extremely graceful in their form, and enriched with brilliant colouring. The small twisted tubes which encrust the old bottles or dead shells dredged up from any of our bays, form an example of this group. They are the dwellings of Worms bearing the name of Serpulce (Fig. 24). If, while the animals are still alive, they be placed in a vessel of sea-water, few sights are more pleasing than that which they exhibit. The month of the tube is opened by the raising of a beautifully formed door, and the delicate fan-shaped gills are then cautiously stretched forth.

The members of the fourth tribe present, in their habits, a complete contrast to the last. They are formed for moving about, and some amoug them can swim with considerable swiftness (Fig. 25). The roving 
life they lead has induced Milne Edwards to bestow on them the expressive name of Errantes, or wanderers.

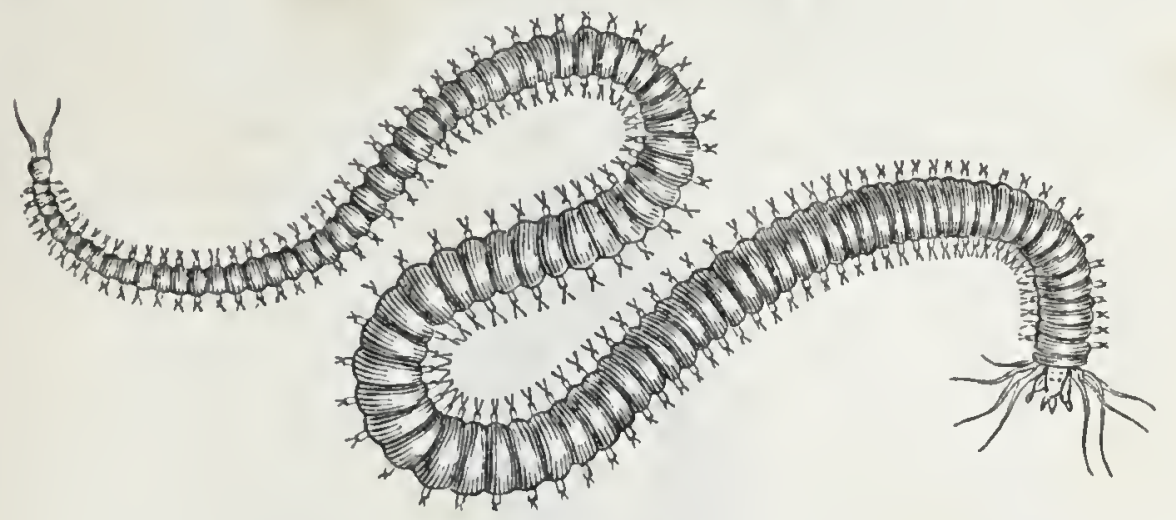

Fig. 25. -NEREIS.

Among these humble animals are some which have the power of giving forth light. One has been observed in Ireland on some of the extensive tracts of bog; and Dr. R. Ball, when passing at night between the islands of Arran, in the Bay of Galway, had an opportunity of observing a similar power in one of the marine species. As soon as the dredge was let down, a blaze of light flashed from the grass-wrack with which the bottom was covered; and as the boat was pulled along, "the dredge seemed as if filled with liquid molten silver." On drawing it up, the light was found to proceed from numbers of a very small species of worm, of a bright red colour, and so soft that they could not be taken out of the dredge. By day-light, it is probable, their very existence would have been unnoticed. 


\section{Class II.-TURBELLARTA.}

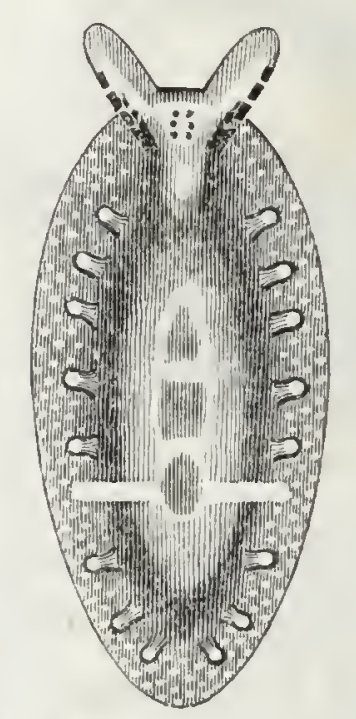

Fig. 26.-TurRELLARIAN.

The animals that form this class, though found both in fresh and in salt water, are so little known, except to naturalists, that they do not possess an English name. The entire body is covered with cilia, those little hair-like organs that have been already mentioned (page 11); and this circumstance, with other points in which they differ from the true Worms, causes them to be grouped together as a distinct class.

If one of the floating leaves of our common pondweed be lifted from the water, and attentively examined, small Leech-like creatures may often be observed crawling on its under surface. These are usually dark-coloured, and belong to the class which we now treat of. They are known under the name of Planaria.

Though these animals are found only in fresh or 
in sea-water in these countries, those living in tropical countries do not thus limit their range. Mr. Darwin found eight species at Rio de Janeiro, striped with bands of gay colour's, and apparently living on decaying timber, among which they were found. They have also been observed in Brazil.

\section{Class III.--INTERNAL PARASITES.}

ENTOZOA.

The body of one animal often forms the abode of many other animals that live within it. These creatures constitute the class Entozoa, a word which simply means "within an animal," and is very appropriate to the internal parasites which constitute the present group.

With this class we are as yet imperfectly acquainted; but some idea of its numbers may be formed from the fact, that no species of animal is supposed to be exempt from their attacks, and that the human body is said to be infested with twentyfive or thirty different species.

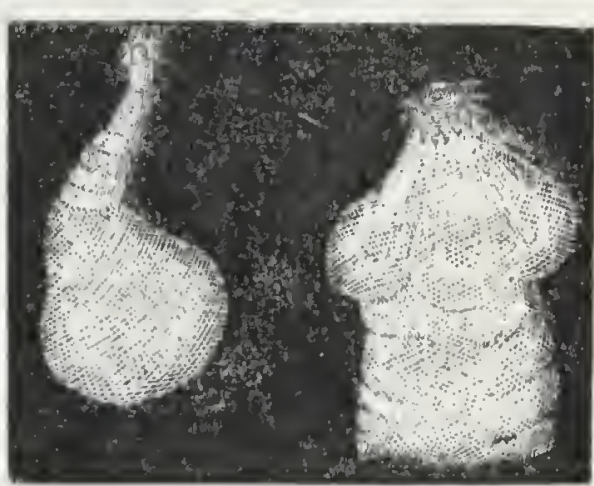

Fig. 27. -EnTuZoon.

These singular beings differ widely in their struc- 
ture. The farmer is well acquainted with two kinds

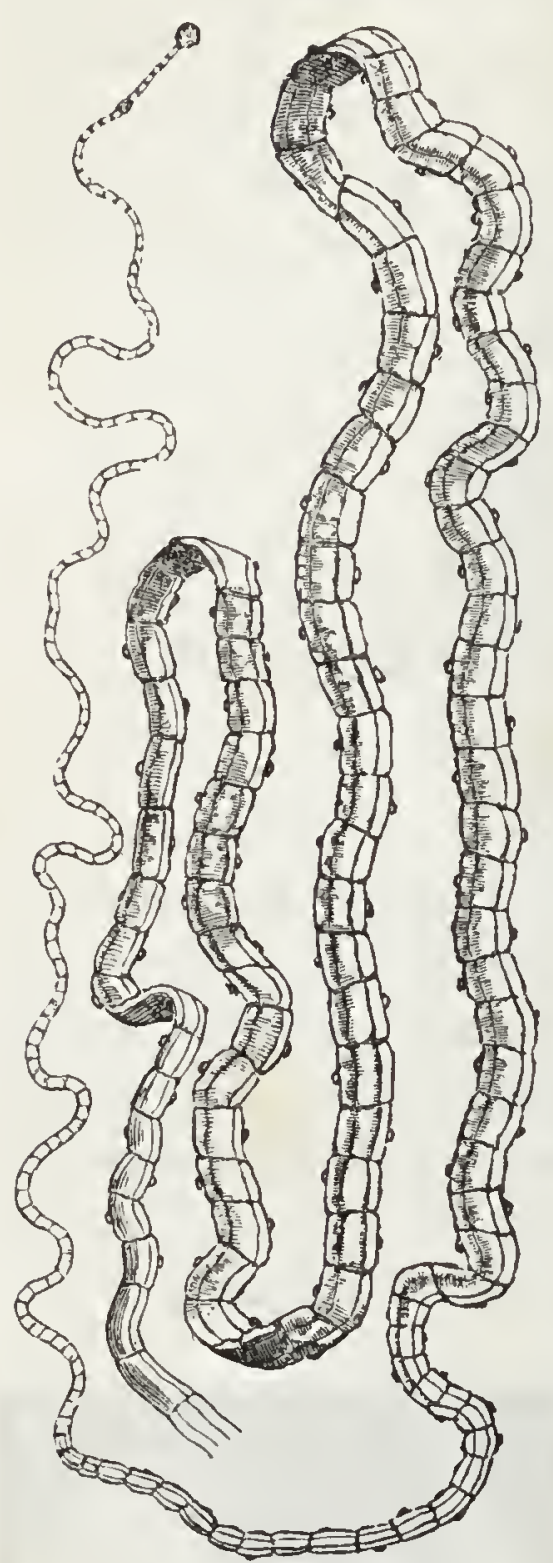

Fig. 28.-TAPE-WORM. -one found in the brain, and another in the liver of the sheep. Some, in a certain stage, are like little bladders filled with water. It is one of these (Fig. 27) that gives to the flesh of the Pig the appearance termed measly. One species that infests the human body is the common Tape-worm (Fig. 28), which is occasionally found several yards in length. Its head is furnished with suckers and bristles, by means of which it can fix itself securely. Each joint of the body has the power of producing numbers of ova or eggs. When these come to maturity, the lower portion of the body separates from the upper, and a fresh series of joints is soon produced; so that, in this manner, the Tape-worm has the power of increasing itself to almost an unlimited extent.

There is a species of Worm called the Hair-worm, which is abundant during a part of the summer in rivulets. Its length is about eight or ten inches, and the common superstition about it is, that horse- 
hairs placed in water become endowed with life, and are changed into these Worms. This notion, with the addition that the Hair-worm was the young state of the Serpent, was prevalent in the days of Queen Elizabeth, for we find it thus recorded by Shakespeare,-

\section{"Much is breeding,}

Which, like the courser's hair, hath yet but life, And not a serpent's poison."

Such of my young readers as have taken the Hairworm in running brooks, in the full light of a summer's day, may wonder why it is noticed among the present class. But the truth is that the Hair-worm is itself, in its young state, an intestinal Worm, living in the bodies of water insects. It is frequent also in that of the Grasshopper, where it may be found in very small space, rolled up into a ball. After leaving this strange dwelling-place, it ends its life in some stream of water or rustic spring, where its eggs are laid in long chains.

\section{Class IV.-WHEEL ANIMALCULES.}

\section{ROTIFERA.}

Tur animals of this class derive their name from the lobes by which the mouth of some species, such as the common Rotifer (R. vulgaris), is surrounded. These lobes, when viewed under a microscope of low power, 
present the appearance of wheels in rapid motion. It was formerly a question how this was to be explained: but now it is known that these lobes are fringed with

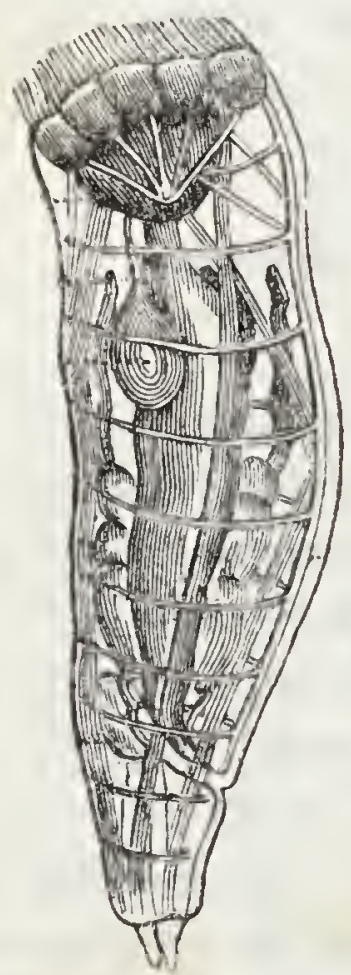

Fig. 29.-ROTIFER. cilia, or minute hair-like bodies; that the movements of these cause currents in the water, which bring to the animal its supply of food; and that they at the same time give rise to that appearance from which the class takes its name (Fig. 29).

Ehrenberg placed these animals in the class Infusoria. A truer knowledge of their structure has caused them to be transferred from their former position to that which they now occupy. All naturalists are agreed that this more elevated rank is only that to which they are justly entitled; but there is as yet a difference of opinion whether they are more closely allied to the Worms or Crustacea.

They possess a highly organized body. Some swim freely about, others are stationary, and hence they capture their food in very different modes. The sexes are distinct, and their powers of increase most wonderful. Though they live in water, they can bear removal from it without loss of life. The body, even if seemingly dried up, has been known to revive when supplied with moisture. 
Class V.-CRABS, LOBSTERS, SHRIMPS; de.

\section{CRUSTACEA.}

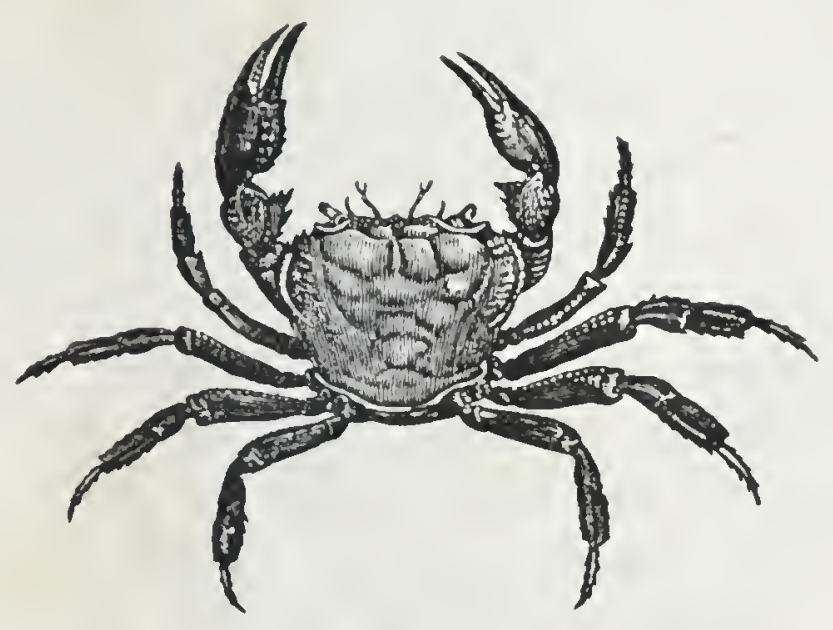

Fig. 30.-THELPHUSA.

TuE scientific name of the present class refers to the shelly crust or corering by means of which the Crab and the Lobster are protected. In the smaller species it bear's a resemblance to horn or parchment.

They all breathe by means of gills or branchice. These, and the greater number of limbs or appendages which many jossess, are sufficient, in most cases, to distinguish them from all other classes of jointed animals. Several are furnished with powerful jaws. In many the mouth is formed for taking food by suction. The sexes are usually distinct.

They are very widely spread, not only throughout the ocean, but through ponds, lakes, ditches, and running waters. In the polar seas they are found in great abundance, though the number of species is very limited. In the regions near the equator, while 
they are no less numerous, they present a greater variety of form and attain a larger size. Mr. Darwin tells us that in the sea around Tierra del Fuego, and at no great distance from the land, he saw narrow lines of water of a bright red colour from the number of Crustacea. But they are not limited to waters, whether salt or fresh. There are some species which pass much of their time on the land; and there are others which come to it only as occasional visitors.

Every one who has opened the "shell" of the common Crab has noticed a number of leaf-like organs, regularly arranged into two parcels, with the points of the little leaves or plates in each parcel brought nearly together. These are the gills, - organs admirably adapted to the habits of the animal.

In the Lobster the arrangement of these parts is different. In other Crustacea the gills are formed like feathery tufts, and float freely in the water (Fig. 31); while in those that live partially or

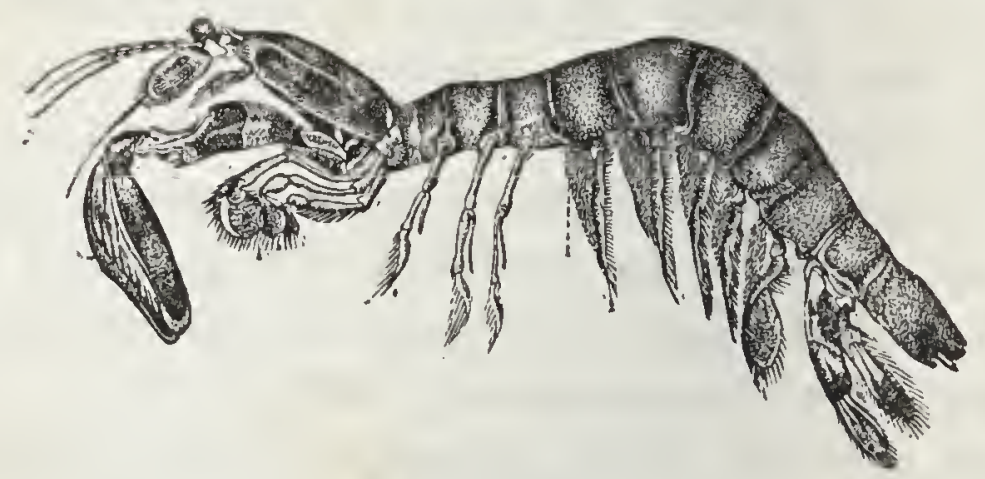

Fig. 31.-SQUiLLA.

altogether on land, contrivances of different kinds exist to retain so much water as to enable the gills to perform their office. 
The young of many Crustacea, on first coming forth from the egg, appear very unlike the adult individuals of the species to which they belong. Those who have only seen the common edible Crab (Cancer pagurus, Fig. 33) in its mature condition, will perhaps be surprised to learr that it existed at one time under the form represented in Fig. 32, its member's being adapted for swimming, and its body so minute that its natural size, when in that state, is shown by the speck adjoining the letter $n$.

All the Crustacea possess the power of producing again parts that are injured. Thus, if the leg of a Crab be fractured, it throws off the injured limb near to the body. The bleeding then

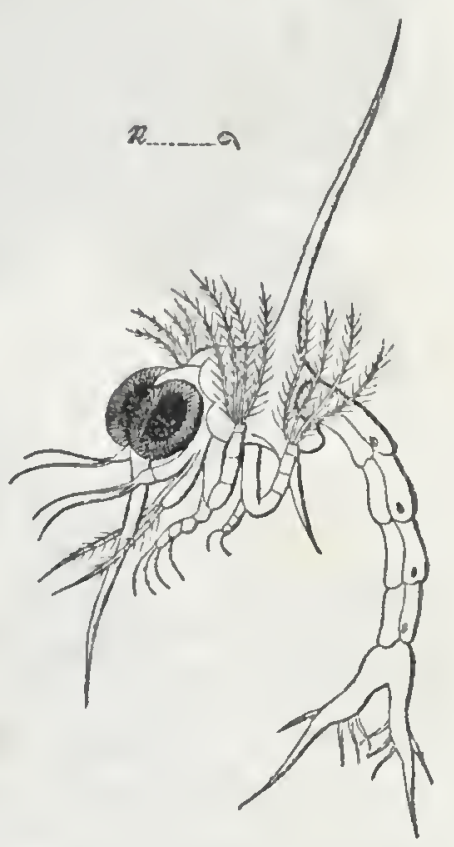

Fig. 32.-YOTNG OF THE Common Crab. stops, and a new limb is gradually formed. Another provision exists by which the growing animal throws off its "shell," and is supplied with one of larger size. In two or three days the new covering assumes the hardness of the old one; and, until then, the animal, as if conscious of its defenceless state, avoids being seen as much as possible.

The Crabs used as food are, of course, those which are most valued and sought after: The large edible Crab is that which, in the north of Ireland, is known as the Crab (Fig. 33). It is most generally taken round our shores by means of wicker baskets, in form like the cage-shaped wire mouse-traps, and baited 
with guts of fish or other refuse; but it is sometimes

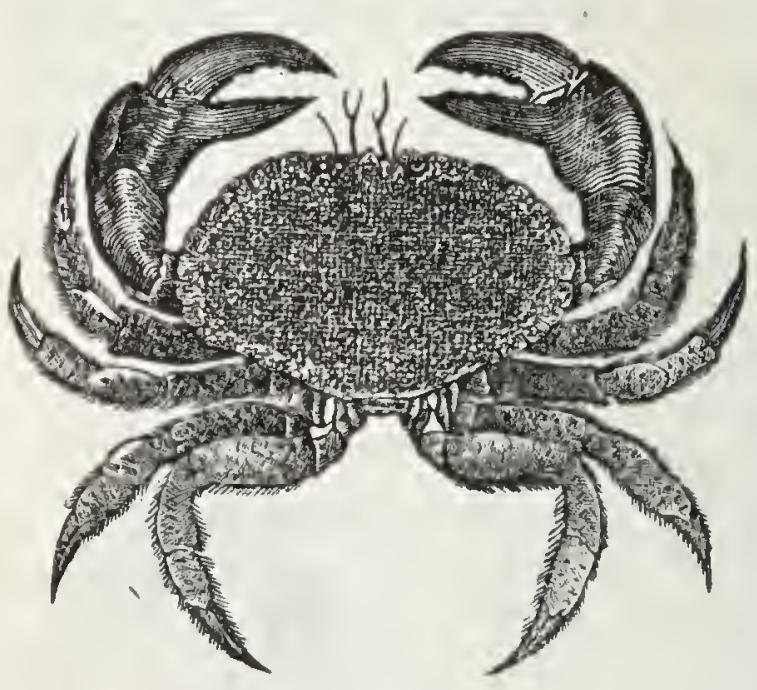

Fig. 33.-Caxcer Paguros. secured by means of a piece of hooked iron thrust into its retreats at low water.

The smaller edible Crab of British authors is the most common species round the entire coasts of Great Britain and Ireland, lurking beneath stones or tangle, or half concealed in the moist sand. We learn from Leach that this species " is sent to London in immense quantities, and eaten by the poor, who esteem it a great delicacy." It is used in like manner in Paris, but is never offered for sale in the markets of the north of Ireland.

The Pea-crabs form an interesting group, from their very small size, and their singular habitation in those shells which, like the Cockle, are composed of two pieces or valves. One of these was celebrated in connection with the Crab, as,

"The anchored Pinna and her Cancer friend,"

the Pinna, according to tradition, being warned of the approach of danger by the quickness of the little Crab, who was the joint and friendly occupant of her mansion. Two, and even three Crabs, are occasionally found in one Mussel or one Pinna.

The Hermit-crabs belong to a different division. 
The tail is prolonged and soft, and hence, in selfdefence, the animal is obliged to occupy some univalve shell, which has been deserted by its original occupant. When thus in search of a dwelling-house it presents an amusing spectacle as it inserts the tail successively into several shells until one is found to fit. From the fact of each Crab being the solitary inmate of its retreat, the common English name has no doubt been bestowed.

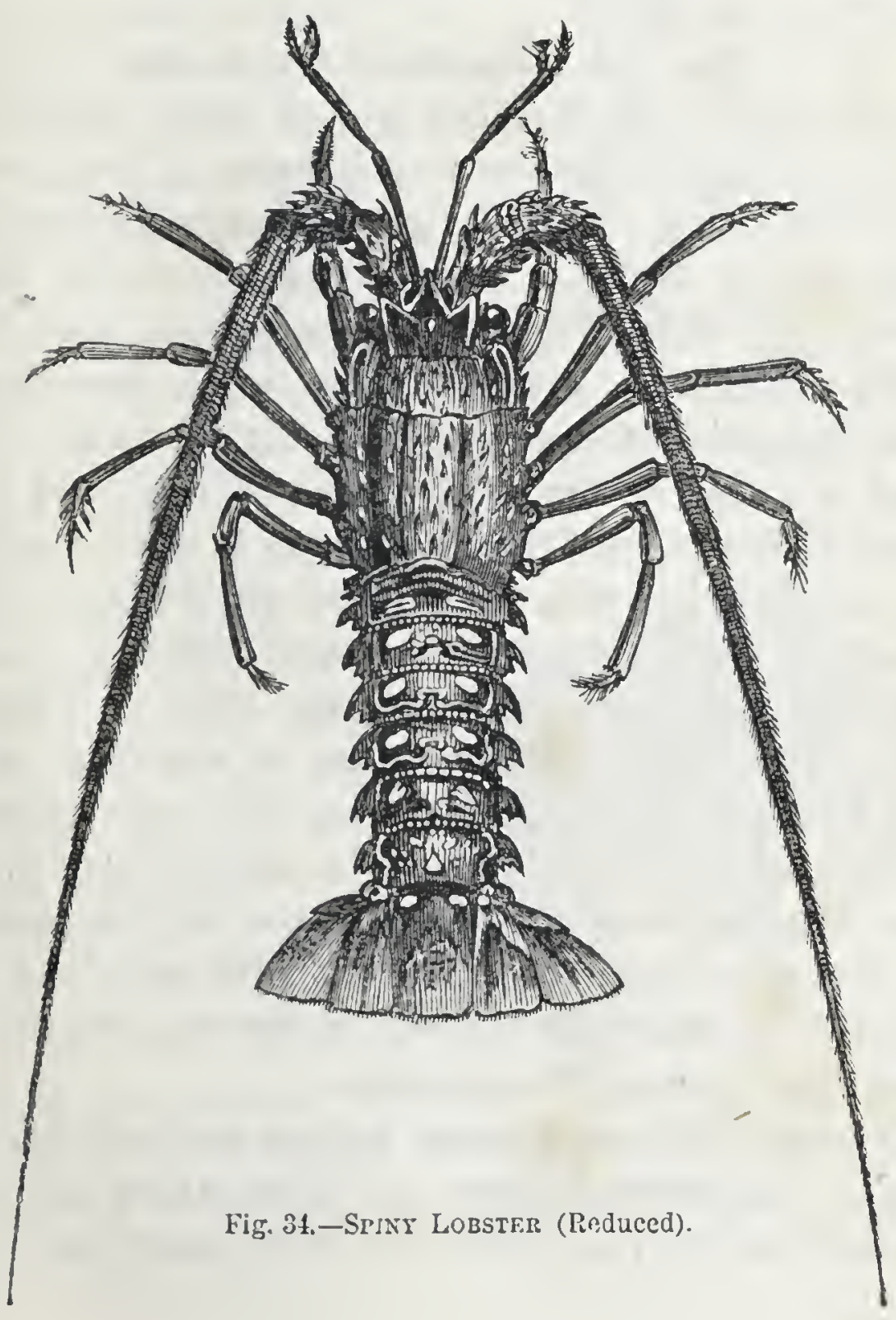


In the group of Crustacea to which the Lobster belongs, the tail is not only longer, but is different in form, being divided into five broad, flat pieces, so as to act with great effect upon the water. The common Lobster is taken all round the rocky portions of the coast. A different species, the Spiny Lobster (or Sea Cray-fish), is shown in the annexed figure. To the same division the true Cray-fish, an inhabitant of rivers, belongs.

All of those yet enumerated are aquatic, but the Land-crabs of the Antilles and of India furnish us with examples of species very different in both structure and habits. "All the grass through the Deccan," says Bishop Heber, "usually swarms with a small Land-crab, which burrows in the ground, and runs with considerable swiftness, even when encumbered with a bundle of food almost as big as itself. This food is grass, or the green stalks of rice; and it is amusing to see the Crabs sitting, as it were, upright, to cut their hay with their sharp pincers, then waddling off with their sheaf to their holes as quickly as their sidelong pace will carry them." Colonel Sykes states that another species is abundant along the Ghāts in India, and also on the most elevated table-lands, intruding themselves into the tents, and even invading such beds as are placed on the ground. In one place, at an elevation of 3,900 feet above the level of the sea, their burrows render it unsafe to ride over many parts of the mountain.

Among Crustacea of more minute size, and belonging to a different division, are those which are seen in numbers in the clear little rock pools round our 
coast, sporting amid the sea-weeds and corallines; and also those which abound both in still water and in running streams, and which may not unfrequently be seen in the water which is brought into our houses for domestic use. Among the latter, the little Waterflea (Fig. 35) may be mentioned. It may easily be detected by its strange, jerking movement, and frequently by its reddish colour.

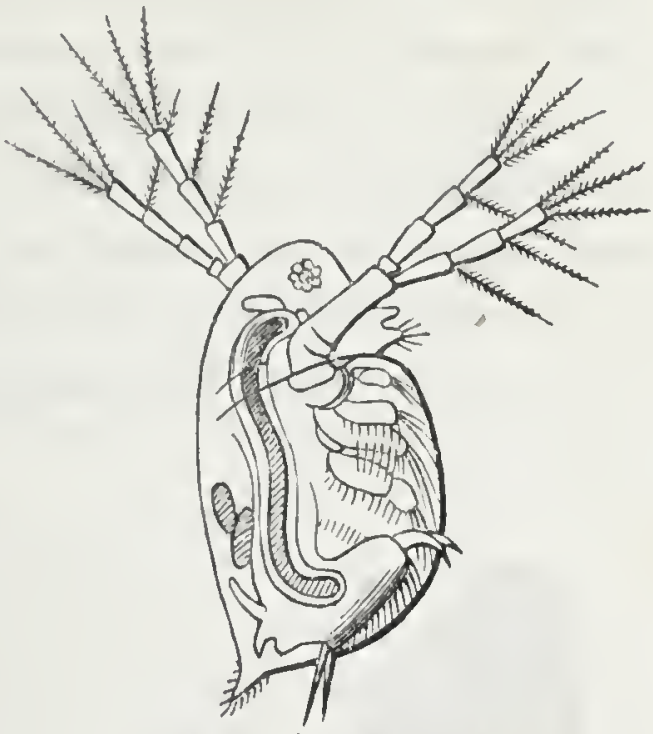

Fig. 3j.-Water-FLEd。

In fact, this last characteristic is so obvious that pools in which they are particularly abundant present an appearance as if blood were mingled with the water.

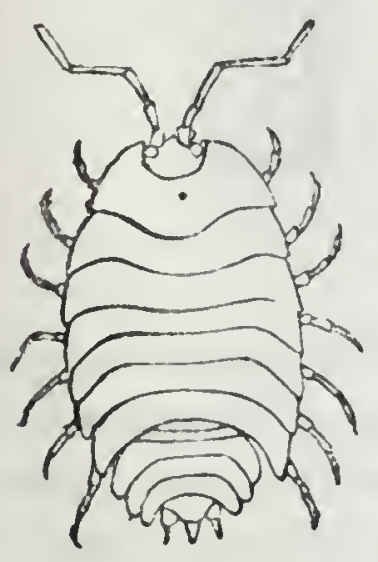

Fig. 36.-WOOD-LOUSE.

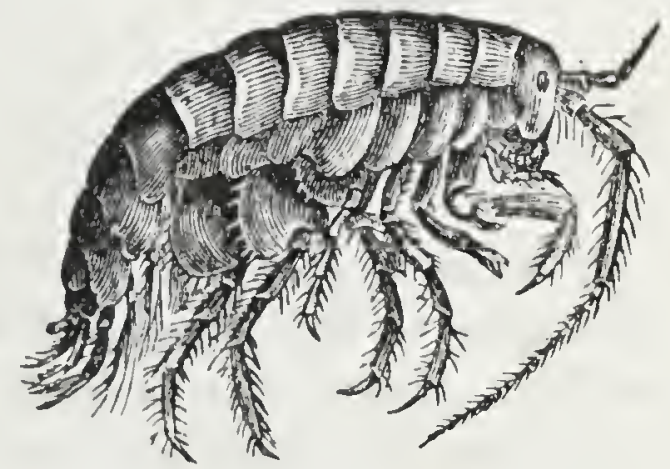

Fig. 37.-Sand-hopper (Magnified).

Fig. 36 represents a species which lives altogether on land,- the Oniscus or Wood-louse. It prefers dark and damp situations, and lurks under stones, slates, and decaying timber. 
Different from any of these are the multitudes of little creatures which abound along the moist margin of the sea, and are known as Sand-hoppers (Fig. 37). They must be of vast service in removing any of those matters thrown up by the tide, which otherwise might taint the purity of the air. We have seen them on one occasion attack the young living fry of Herrings just cast upon the beach, and with wonderful rapidity clean away the flesh, leaving only a delicate skeleton.

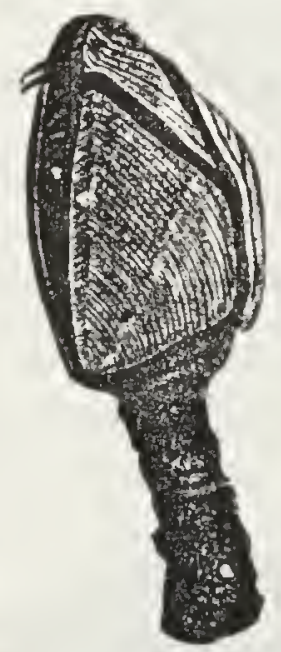

Fig. 33.-Shell of Lepas.

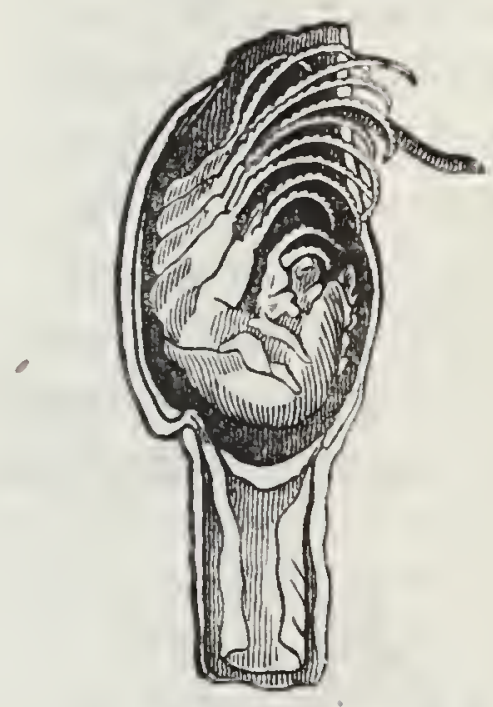

Fig. 39.-BODY OF Lepas.

BARNACLES. - Out of the immense variety of animals belonging to the present class, we can mention only one other group. It consists of animals covered with shells, these shells being made up of several pieces. Some are known as Barnacles, and are frequently seen attached to floating pieces of timber. Others abound on the rocks of many parts of our coast, and are called Acorn-shells. This group is remarkable for a tradition which yet exists, and which cannot be better told than 
in the words of an old writer, who gave entire belief to the tale which he records:-

"There are found in the north parts of Scotland and the islands adjacent, called Orchades, certain trees, whereon do grow certain shells of a white colour, tending to russet, wherein are contained little living creatures; which shells in time of maturity do open, and out of them grow those little living things, which, falling into the water, do become fowls which we call Barnacles."

These words occur in Gerardes's Herbal, or General History of Plantes, a work published in 1597; and the statement is given by that author on the authority of others. He then goes on to say, "But what our eyes have seen and our hands have touched, we shall declare. There is a small island in Lancashire, called the Pile of Foulders, wherein are found the broken pieces of old and bruised ships, some whereof have been cast thither by shipwreck, and also the trunks and bodies, with the branches of old and rotten trees, cast up there likewise, whereon is found a certain spume or froth, that in time breedcth unto certain shells in shape like those of a Mussel, but sharper pointed and of a whitish colour; wherein is contained a thing in form like a lace of silk finely woven, as it were, together, of a whitish colour, one end whereof is fastened unto the inside of the shell, even as the fish of Oysters and Mussels are; the other end is made fast unto the belly of a rude mass or lump, which in time cometh to the shape and form of a bird; when it is perfectly formed, the shell gapeth open, and the first thing that appeareth is the aforesaid lace or string; next come the legs of the bird hanging out, and, as it groweth greater, it 
openeth the shell by degrees, till at length it is all come forth, and hangeth only by the bill. In short space it cometh to full maturity, and falleth into the sea, where it gathereth feathers, and groweth to a fowl bigger than a Mallard and lesser than a Goose."

We may sinile at the extravagance of these ideas, and wonder how fancy could have invented such tales. But the wildest stretch of imagination could not venture upon anything more wonderful than the real facts respecting the changes which these animals undergo.

Before the shelly covering of that Barnacle was formed, the creature, not fastened as now by its fleshy stalk, was gifted with the power of moving freely about, and had one central eye. The animal, too, of that Acorn-shell, now fixed so immovably upon the rock, had, at one time, an oval figure, two eyes mounted upon footstalks, and six pair of jointed legs, which, keeping stroke like so many oars, drove it onwards (Fig. 40). At a

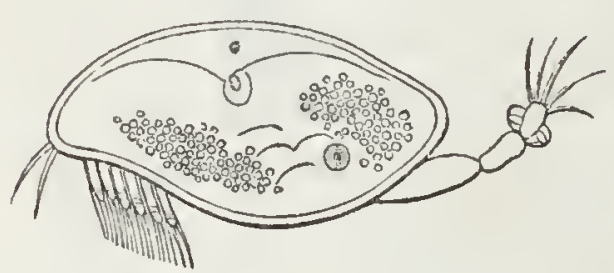

Fig. 40. YOUNG OF ACORN-SHELL. certain period its wandering habits were laid aside, its future restingplace was chosen, and then, attaching itself securely to this place, its shelly covering was secreted, and the power of sight, no longer needful for the welfare of the animal, was extinguished for ever.

In our progress through the animal kingdom, we meet with many other instances of the young being bountifully gifted with powers which the animal in its mature condition does not possess. 
The figures here given (Figs. 38, 39) of Barnacles, exhibit the pedicle or stalk by which they are attached to floating pieces of timber; and that of the Acornshell (Fig. 41) shows the shelly base by which it is fixed to the rock or other body on which it is found. The organs which give to the group the scientific name $\mathrm{Cir}$ ripectia, signifying "curl-footed," are also represented, so that this peculiarity of structure will be easily understood and remembered.

But if my readers would see it in full perfection, let them go at

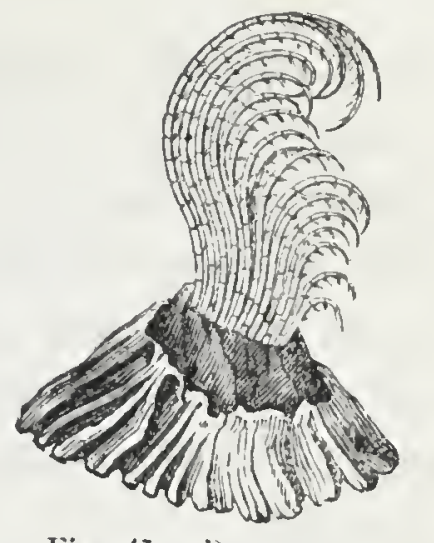

Fig. 4I.-BALlax LS, OR ACORN-SIIELL. low water to the beach, and choose a few of the largest limpets, covered over with the Acorn-shells. Place them in a glass of sea-water, and watch the manner in which the Acorn-shells open at the summit, and put forth their plumes. Thus seen, the movements of the animal, as it throws out its feathered arms to seize its food, are very easy and graceful, and will afford pleasure to every thoughthful observer, whether young or old. 
Class VI.-CENTIPEDES, \&C.

\author{
MYRIAPODA.
}

THe animals belonging to this class in many respects resemble the true insects, from which, however, they

- differ in possessing a much greater number of legs. The name of Myriapoda, given to these creatures, has reference to this important feature. The body is, in most cases, divided into numerous rings or segments, and usually is invested with a rather firm covering.

In some members of the group, as in Juhus (Fig. 42),

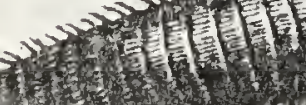

(X)

Fig. 42.-JULUS.

the legs are slight and thread-like, but in others, as in the Centipede' (Fig. 43), they are strong and active, and well adapted to bear their owner into the lurkingplaces of the unfortunate insects on which he preys.

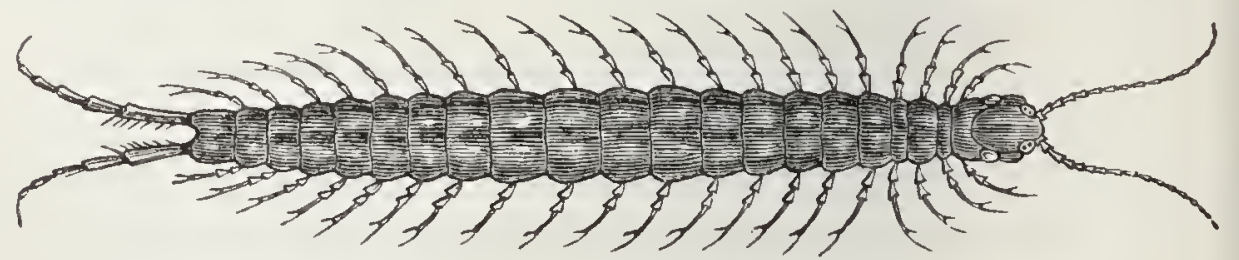

Fig. 43.-Centipede.

Some of the foreign species belonging to this class grow to a great size. Humboldt mentions that he has seen some eighteen inches long, and that these were pulled out of the earth, and eaten by Indian children. 


\section{Class VII.-INSECTS.}

INSECTA.

"The insect youth are on the wing, Eager to taste the honied spring, And foat amid the liquid noon:

Some lightly o'er the current skim, Some show their gaily-gilded trim, Quick glancing to the sun."-GRAY.

TuE word insect is derived from a Latin term signifying " cut" or "notched," the body being deeply cut into segments. The body consists of three portions, * and the legs are six in number (Fig. 44). Insects breathe by means of small orifices or openings placed along the sides, and communicating with tubes which divide into innumerable

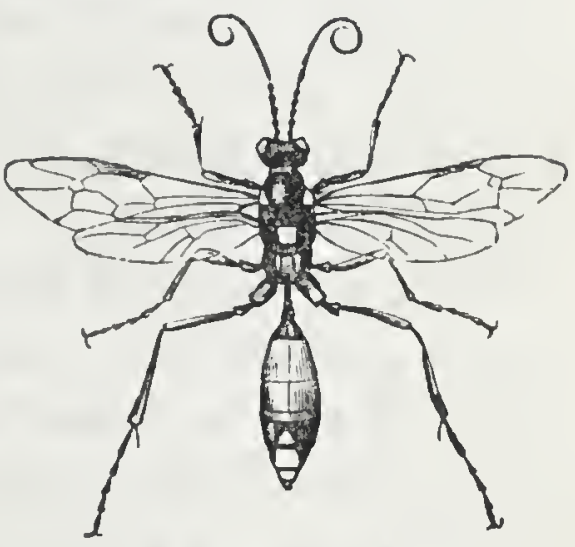

Fig. 44.-ICHNEUMON. branches, and convey the air to every part of the body.

With regard to the external senses, it is generally allowed that insects possess those of touch, taste, and smell. That of hearing was formerly denied to them even by distinguished naturalists. Shakespeare entertained a different and more correct opinion when he used the words,-

\section{"I will tell it softly;}

Yon Crickets shall not liear me."

* These are the head, the thorax or chest, and the abdomen. The legs and wings are attached to the thorax. 
The observations, however, of Brunelli, an Italian naturalist, settle the question. Several of the Fieldcrickets which he kept in a chamber continued their crinking song through the whole day; but the moment they heard a knock at the door they were silent. He afterwards invented a method of imitating their sounds, and when he did so outside the door, at first a few would venture on a soft whisper, and by and by the whole party burst out in a chorus to answer him; but upon repeating the rap at the door, they instantly stopped again, as if alarmed. He likewise confined a male in one side of his garden, while he put a female in the other at liberty, which began to leap so soon as she heard the crink of the male, and immediately came to him-an experiment which he frequently repeated with the same result.

There are some insects in which no organs of vision have been discovered; but in general they are not only very obvious, but present considerable variety in colour, form, position, and structure. The most usual number of eyes is two; but when it is needful that the insect should, at the same time, have the power of observing objects in the air and in the water, it is gifted with four eyes, as in the common Whirl-gig (Gyrinus, Fig. 45), which may be seen on our ponds and streamlets. The eyes are sometimes simple; but the most common kind is that which is termed compound. Such eyes, when Fig. 45. GYRINUS. separated and made clean, are as transparent as crystal. Their number is extremely variable, and cannot but strike the most indifierent with astonishment. "What would he thought of a quadruped whose 
head, with the exception of the mouth and place of juncture with the neck, was covered by two enormous masses of eyes, numbering upwards of 12,000 in each mass? Yet such is the condition of the organs of vision in the Dragon-fly." By this arrangement the want of motion in the eyes is more than made up for by the abundance in which these organs are bestowed.

No one circumstance comnected with insects has perhaps arrested the attention of ordinary observers so much as what is termed their "metamorphoses." The higher animals retain through life, with some variations in size and colouring, very much the same forms which they had at birth. But most insects, on the contrary, pass through four states of existence; and these are in general distinctly marked. They are first contained in eggs, which are laid by the parent in suitable situations, and with a degree of care which fills us with admiration. They then become active and rapacious, and are well known by the names of Grubs, Maggots, and Caterpillars, according to the tribes to which they belong (Fig. 48). To this condition Linnæus applied the Latin word larva (a mask), as if the perfect insect were masked or concealed in the figure of the Caterpillar. The ravages of which the forester and the gardener complain, result most generally from the voracity of insects in their larva state. They eat much, increase rapidly in size, change their skins several times, and pass into another state, in which, in some. tribes, all appearance of vitality is for a time suspended. The Caterpillar of the Butterfly or Moth, when the time for this change arrives, seeks out a place where it may be secure during its period of helplessness, 
and suspends itself by a thread (Fig. 47), envelops itself in silk, makes a covering of leaves, or entombs itself in the earth, according to the habits of the species. Some of them in this state appear, on a miniature scale, like Egyptian mummies, or like an infant wrapped up in swaddling-clothes. From this peculiarity the term pupa (a baby) has been given to them; and chrysalis, a word of Greek origin, referring to the bright or

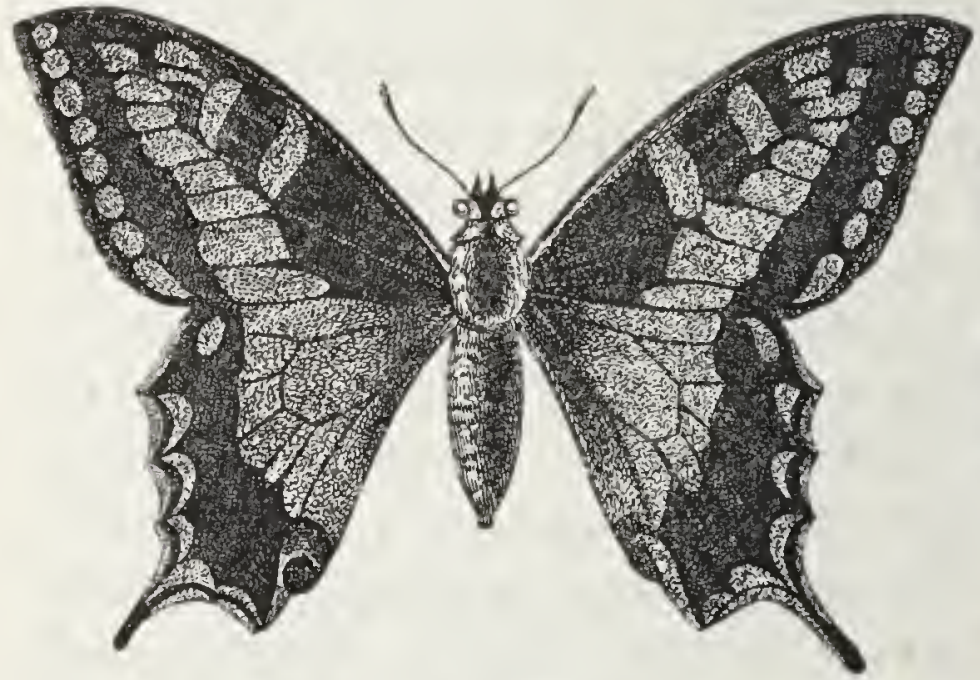

Fig. 46.-Imago of Papilio Machaon.

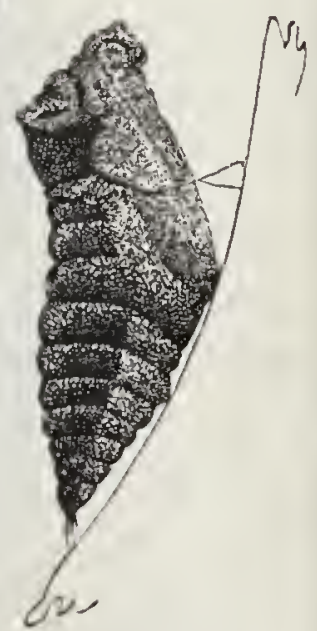

Fig. 47.-PсгA.

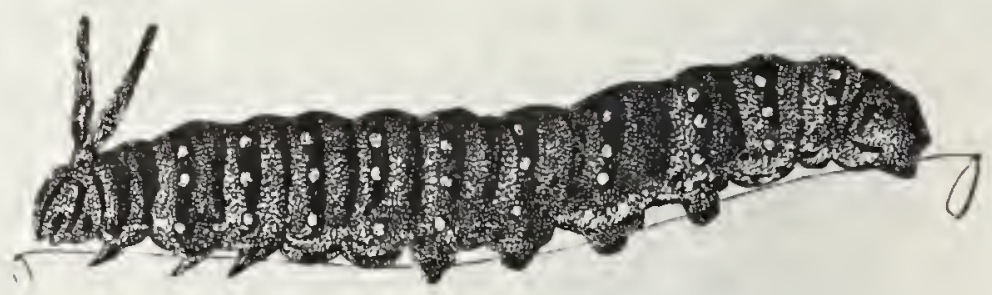

Fig. 48. - Larva of Papilio MachaoN.

golden colours which some of them display, has also been applied. In all cases these terms indicate the form or colouring which the insect presents immediately before its appearance in the last and perfect form-that which is termed the Imago (Fig. 46), as though it had not until then its fully developed or 
perfect image. All insects, however, do not assume this state of rest. The young of the common Gnat pass the early stages of their existence as inhabitants of the water, jerking about with great agility, or swimming with ease and swiftness. The Crickets and Cockroaches are as active and lively at this period of their lives as at any other, and differ in appearance from the perfect insect only in the absence of wings.

There is 110 animal nor vegetable substance which does not furnish food to one or more species of insects. Some live entirely on decaying substances, and, by removing them, help to maintain the purity of our atmosphere. Others prey on those that are weaker than themselves; some feed upon timber; others upon leares and grass; some, like the "worm i' the bud," feast on our loveliest flowers; and others on the nectur of our choicest fruits.

From the great variety of their food, there must also bo a great variety in the instruments by which the

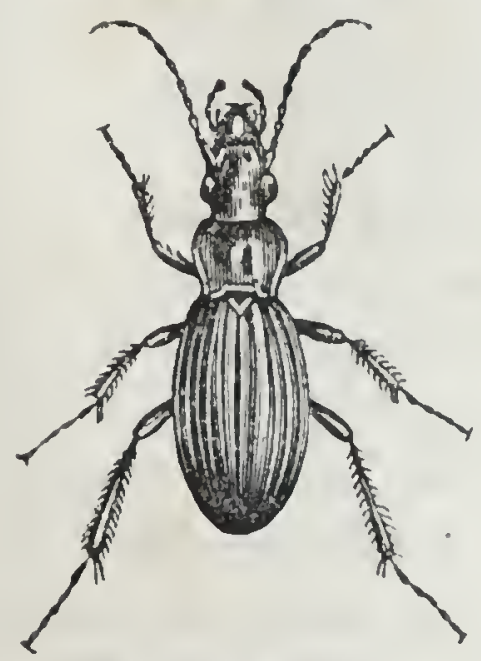

Fig. 49.-CarabUs.

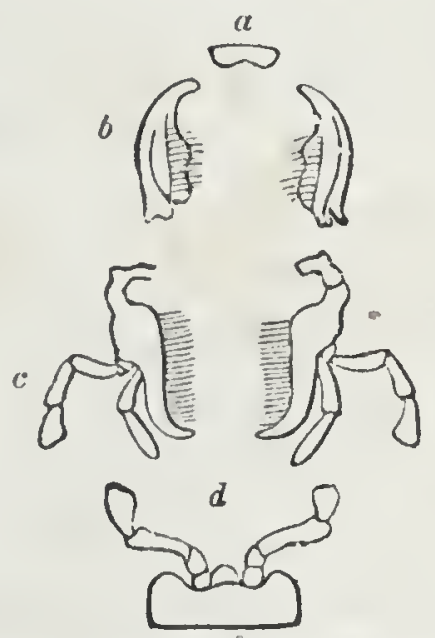

Fig. 50.-Parts of Mouth of Carabus.

food is taken; and accordingly we find the mouth is sometimes furnished with jaws for cutting solids, and 
at others with tubes for sucking up fluids. When all the parts are present, as in the common rapacions Beetles (Fig. 49), the mouth consists of seven parts (Fig. 50). These are, an upper lip (a), a lower lip $(d)$, a tongue, two upper jaws $(b)$, and two lower jaws $(c)$. The motion of the jaws is not vertical, as in the vertebrate animals, but is horizontal ; and the lower jaws are sometimes employed in holding the food, which the upper jaws or mandibles are engaged in cutting to pieces. In some orders the seven parts are not to be seen with such distinctness, some of them , being very much enlarged, and others diminished, or perhaps altogether wanting.

To bring organs which are so very different fully into play, it is necessary that each insect should possess the power of moving with ease to whatever situation its necessities require, and that it should be furnished, for this purpose, with organs of flight adapted to the varying circumstances and wants of the several tribes. These wings never exceed four in number. In Beetles of burrowing habits the upper pair is hard and horny, and serves to protect the softer pair when not in use. In other tribes the wings are like the finest lace; and in the Butterflies and Moths they are covered with a mealy substance, which examination under a magnifying glass shows to be composed of the most delicate scales, differing in form, in size, and in colouring, and giving to some of them the bright tints, like those of burnished metal, for which they are so remarkable.

Professor Owen, in speaking of the wings of insects, says,_- "In no other part of the animal kingdom is the organization for flight so perfect, so apt to that end, as 
in the class of insects. The Swallow cannot match the Dragon-fly (Fig. 51) in flight. This insect has been seen to outstrip and elude its swift pursuer of the

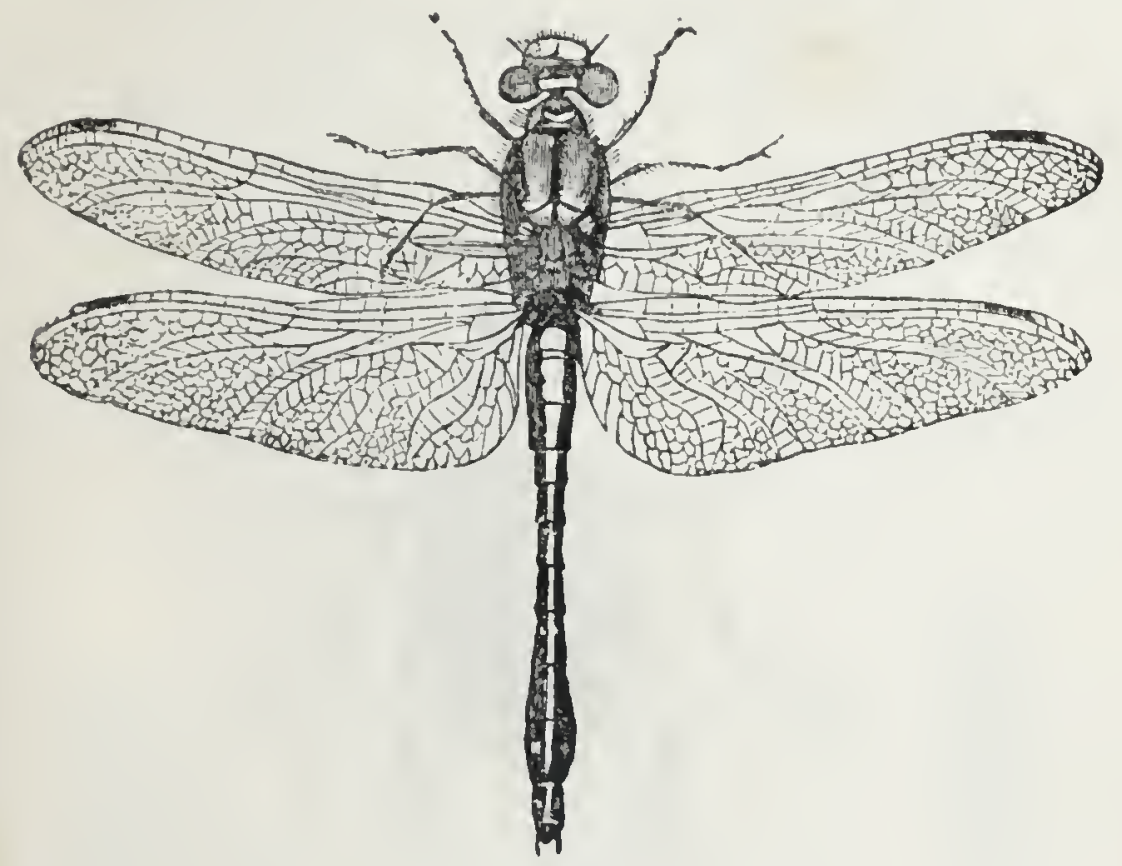

Fig. 51.-DRAGON-FLr.

feathered class: nay, it can do more in the air than any bird; it can fly backwards and sidelong, to right or left, as well as forwards, and alter its course on the instant without turning."

From the great importance of the wings, and from the variety in their structure, they furnish the means of classification, and enable us to arrange the various insect tribes in nine Orders. To each of these our attention may now be briefly directed.*

* It is right, however, to state, that no one system of organs will furnish a perfect system of elassifieation; and that many modern writers prefer arranging inseets aceording to the structure of the mouth, and others according to whether or not they have undergone a metamorphosis, and if so, of what kind. 


\section{Order I.-BEETIES. \\ COLEOPTERA（SHEATII-WINGED）.}

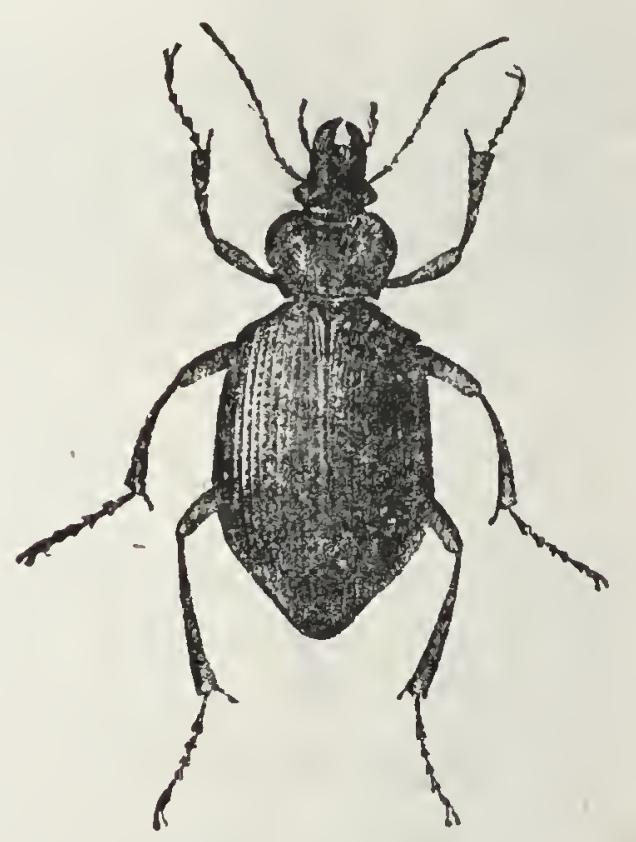

Fig. 52.-CaLosoma.

THE insects belonging to the present order are extremely numerous. It has been calculated that so many as 40,000 species have been already described, of which about 3,000 are natives of these countries. We notice among them very great differences in size, colour, and general appearance. The great Water-beetle is sufficiently powerful to play the tyrant of the pool in which he lives, and even to attack and overcome small fishes. Others, again, are so minute as to live in the small holes they make in the timber of our dwellinghouses, and thus escape the notice of ordinary observers. Among the latter inay be mentioned those little Beetles 
(Fig. 53) to which vulgar superstition has given the name of "Death-watch:"

"The solemn Death-watch click'd the hour she died."-GAY.

This sound, which is only the call of the insect to its companion, so exactly resembles the ticking of a watch, that Dr. Ball, by placing his watch to the wainscot which the little Beetle frequented, caused the insect to respond to its ticking.

In many beetles the wing-cases (elytra) are united together, and as wings could not be used, they are not given. In the Glow-worm (Figs. 54, 55), an insect not

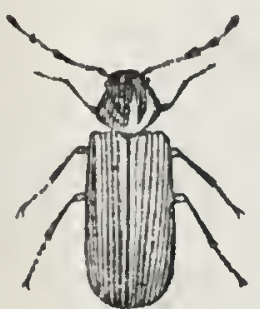

Fig. 53.

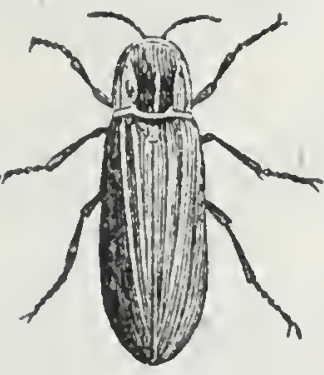

Fig. 54.

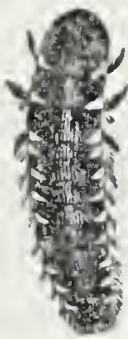

Fig. 55.

Privus (Magnified).

Male Glow-wory. Female Glow-worm. found in Ireland, the female, being soft and wingless, does not seem to belong to the present order; but the male is possessed of wing-covers, and of expansive wings, by means of which he is enabled to shape his course to the light displayed by the female.

The "droning-flight" of the Dor-beetle, heard in the twilight of the summer-evening's walk, is a sound with which every one is familiar; and equally well known is the manner in which the creature startles us by striking against our fices. It is from this circumstance, and not from the actual absence of eyes, that its common epithet, the "Blind Beetle," has been derived. To this family belongs the Sacred Beetle of the 
Egyptians (Fig. 56), whose image remains sculptured on many of their obelisks and other monuments. It still attracts the attention of travellers, from its habit

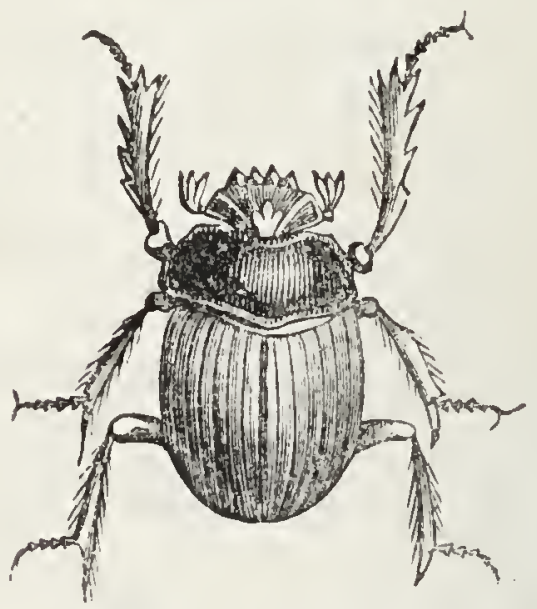

Fig. 56.-SAcred BeEtle of THE EgYPTIANS.

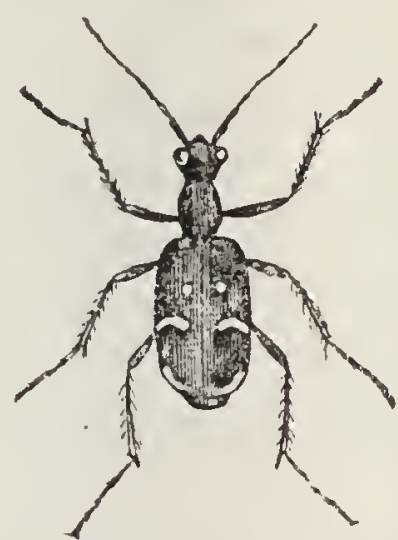

Fig. 57.

Cicindela.

of collecting and rolling about a ball of dung, in which it deposits an egg.

As a contrast in habits to this Beetle may be mentioned the Cicindela (Fig. 57), which is regarded as one

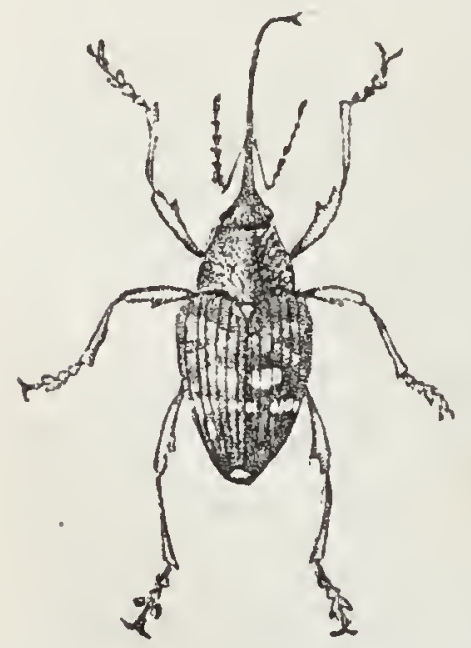

Fig. 58. -NUT-WEEVIL (Magnitied). of the tigers of the insect tribes. Its colour is a golden green, with white or yellow spots; and it appears particularly rich when the insect is running rapidly along in the bright sunshine of a summer's day. Other species carry on their operations so as to escape our notice. Thus the Nut-weevil (Fig. 58), with her long horny beak, drills a hole through the shell while it is yet soft, deposits an egg, and thus furnishes her future offspring with a house for its defence, and food for its support. 
Order II.-CrICKETS, LOCUSTS, \&c.

$$
\text { ortioptera* (straight-Winged). }
$$

Trus division includes in it the Cockroaches, Crickets, Grasshoppers, and Locusts, and those very strange-

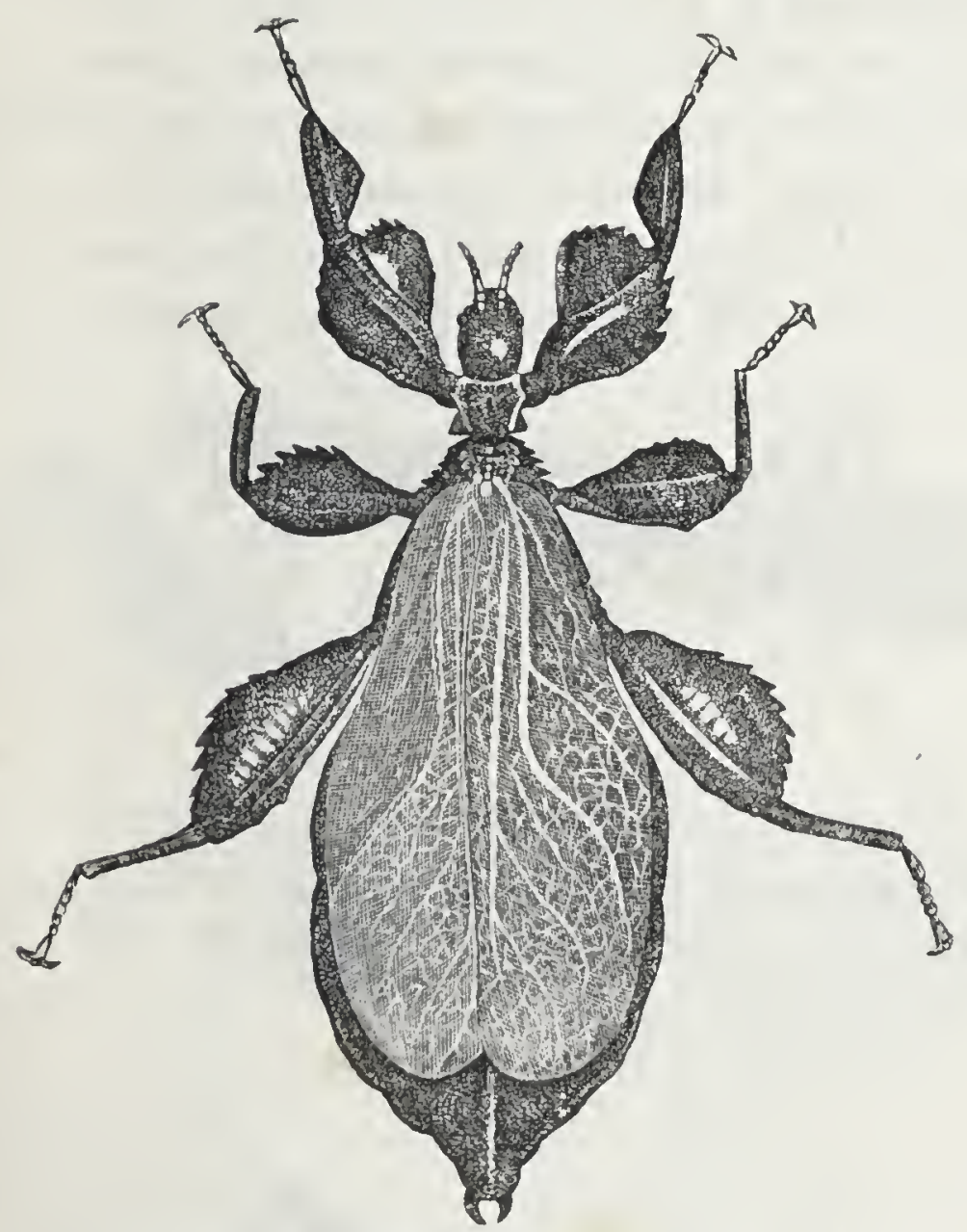

Fig. 59.-LEAF-INSECT.

looking creatures, from warmer climates, which have been, by common consent, named "Walling-sticks"

- Those insects were included by Linnrus under the order Hemiptera, and the opinion is now prevalent, that the two groups should never have been separated. 
and "Leaf-insects." Some species of the latter, which we see in our museums, have the wing-covers of so bright and fiesh a green that we can with difficulty persuade ourselves we are looking on an insect; while others present a no less striking resemblance to the colour of the leaf, and its delicate net-work, as it lies on the groand in its withered state (Fig. 59).

One foreign insect deserves mention, because it has obtained, from its attitude, the name of the "Praying Mantis" (Fig. 60); and popular credulity, both in Europe and Africa, has gone so far as to assert that a child or a traveller who-has lost his way would be guided

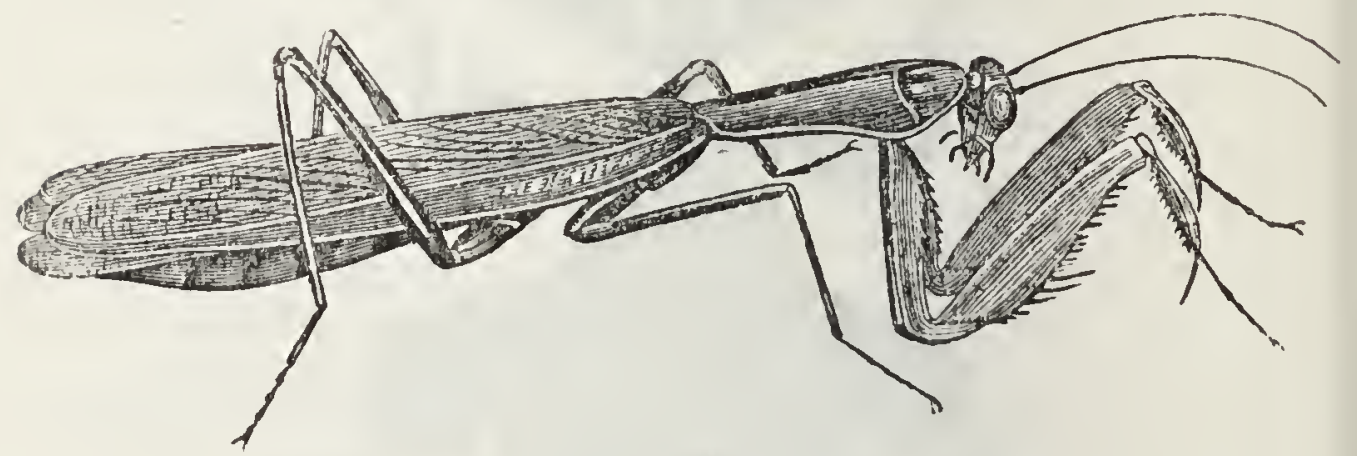

Fig. 60.-MaNTIS.

by taking one of these pious insects in his hand, and observing in what direction it pointed. They have

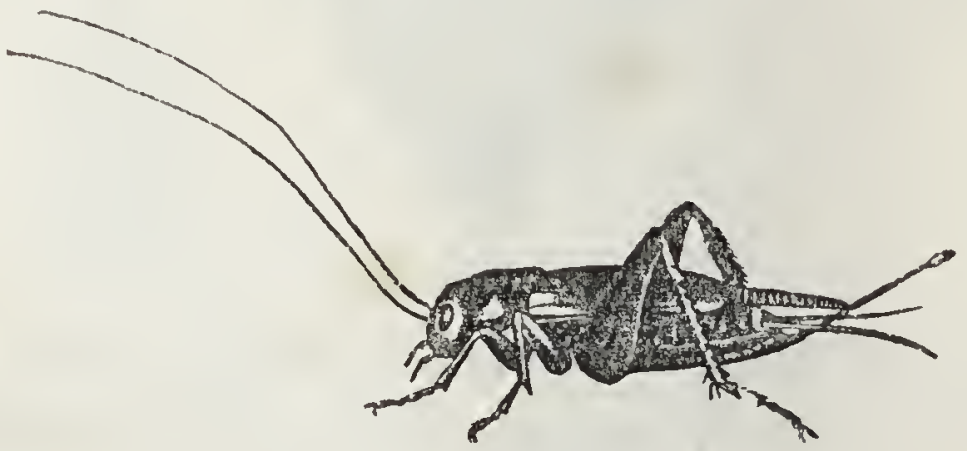

Fig. 61.-HoUSE-CRICKET.

the character of being gentle, while in reality they ar'e extremely ferocious: if one Mantis be engaged in battle 
with another he can cut off the head of his foe at a single stroke, by using one of the fore legs as a sabre.

Perhaps in these countries no individual of the order is so well known as the House-cricket (Fig. 61), which common belief regards as foretelling cheerfulness and plenty. It would be more correct to say, that their presence does not foretell that plenty is to come, but that it already exists. None of our poets lave offered to this insect a more graceful tribute than Cowper,-

"Thou surpassest, happier far,

Happiest Grasshoppers that are;

Theirs is but a summer's song,

Thine endures the winter long,

Unimpaired, and shrill, and clear,

Melody throughout the year."

There is one insect belonging to the present order whose very name -the Locust(Fig. 62) is associated with terror and suffering. The description given by the Prophet Joel of their power, is not less remarkable for its fidelity than its grandeur, "A fire clevoureth before them, and behind them a flame burneth :

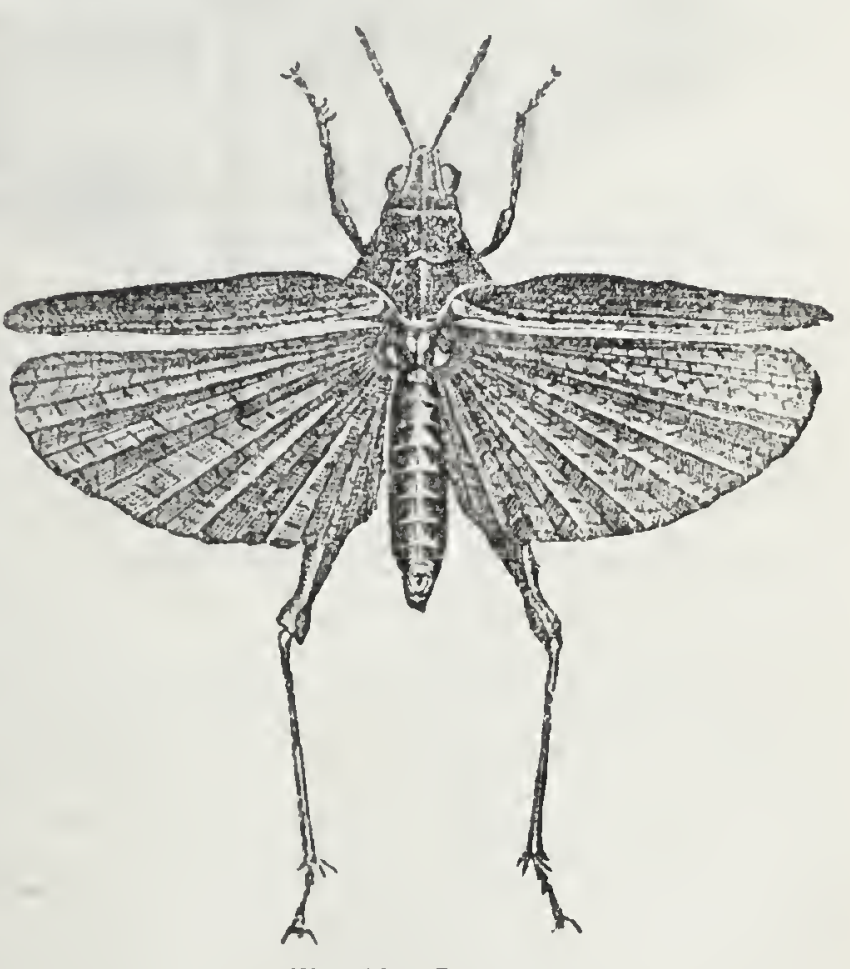
lig. 62.-Locust. the land is as the Garden of Eden before them, and 
behind them a desolate wilderness; yea, and nothing shall escape them. Like the noise of chariots on the tops of mountains shall they leap, like the noise of a flame of fire that devoureth the stubble, as a strong people set in battle array."

Order III.-DRAGON-FLIES, \&C.

NEUROPTERA (NERVE-WINGED).

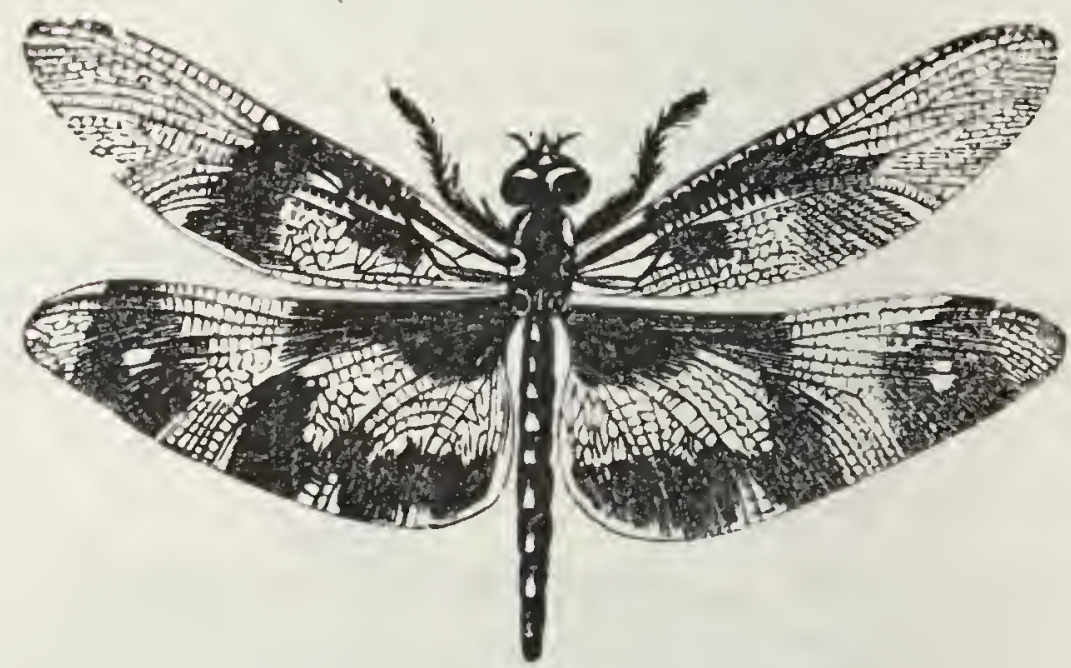

Fig. 63.-Indian Libellula, or DRagon-Fly.

'THis order of insects includes the Dragon-flies, the Lace-winged-flies, the Ephemera, and the destructive Termites, or White Ants. They have, in their perfect state, four large-sized wings, equal in size, and presenting, in some species, an appearance of the most delicate net-work. Here also are placed the Mayflies, whose larva are the well-known Case-worms, or Caddis-worms, of our streams and ditches (Fig. 64).

No one who looks upon any of our native Dragonflies (Fig. 51) hawking orer a pond on a bright summer 
lay, and marks the ease with which their insect prey is taken and devoured, could ever suppose that these
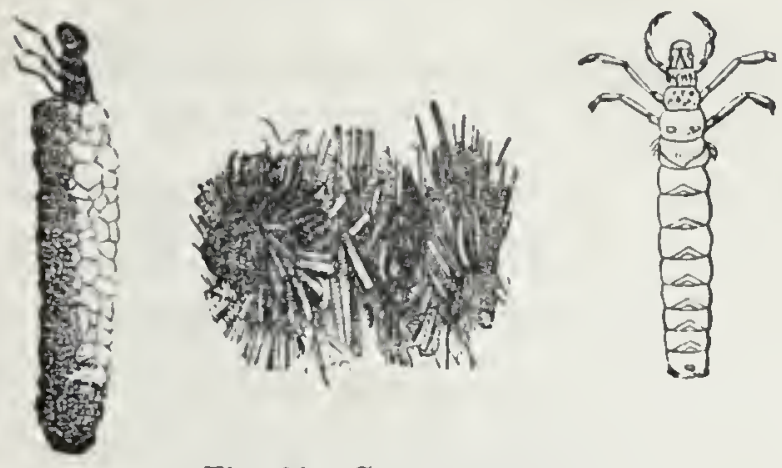

Fig. 64.-Caddis-worms.

swift-flying creatures had, but a few weeks before, been inhabitants of the water. Yet it is there the early stages of their life are passed; for in that element the egrgs are laid by the mother.

Some have the wings expanded horizontally when at rest (Figs. 51, 63); others have them closed and erect (Fig. 6.5); but in both the movements of the insects are so light and graceful, their colour's so splendid, and at the same time so va-

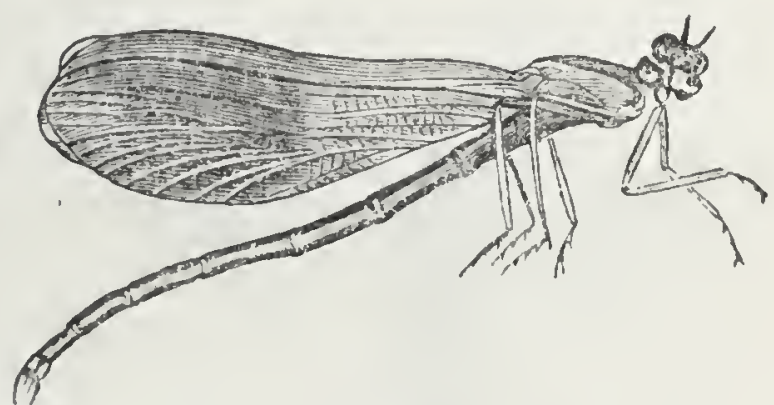

Fig 65.-AGRION. ried, displaying the softest green and the richest azure, that our neighbours, the French, have bostowed on them the name of "Demoiselles;" and one of our poets has applied to them a corresponding term,-

"Chasing, with eager hands and eyes, The beautiful blue damsel-fies, That fluttered round the jasmine stems Like winged flowers, or flying gems."-MоокE. 


\section{6}

Order IV.-BEES, WASPS, ANTS, \&c.

HYMENOPTERA (MIMBRANE-WINGED).

THe insects of this order have four veined wings of a kind of thin membrane, but they are not equal in size, nor do they present the appearance of delicate net-work as in the preceding order. The female is furnished either with a sting, or with an instrument termed an ovipositor (Fig 68), which is used in depositing the ova or eggs. The jaws are powerful, and the tongue, instead of being small and not easily seen, becomes in some tribes an organ of great size and importance. To this order belong the Saw-flies, Gallflies, Ants, Wasps, and Bees.

The Saw-flies (Fig. 66) take their name from a pair

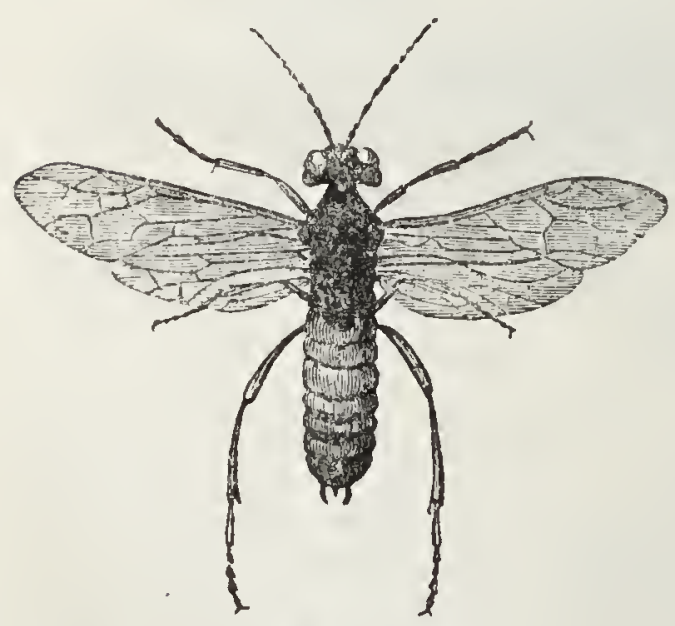

Fig. 66.-SAW-FLY.

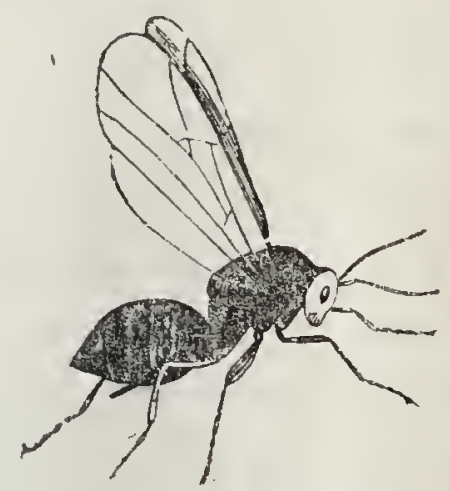

Fig. 67.-GALL-FLY.

of saw-like instruments with which the female is furnished, and which she employs for making a cut or incision, in which she deposits an egg.

The Gall-flies (Fig. 67) are those which puncture 
plants, and, in the wound thus made, insert one of their eggs, along with an irritating fluid, the action of which upon the plant produces tumours or galls of vallious sizes, shapes, and colours. That found on the wild rose, and called the beguar or bedeguar of the rose, is well known.

In the next division (Fig. 68) we find the insects depositing their eggrs, not on the leaf or stem of a tree, but actually in the body of a living Caterpillar: About three thousand of these Ichneumons, as they are called by Linnæus, are'at present known and describer. They all deposit in living insects, chiefly in the larva state, sometimes while in that of pupx, and even in the egg state, but not, as far as is known, in perfect insects. The eggs thus laid soon hatch into grubs, which immediately attack their victim, and in the end insure its destruction.

We now enter upon the eximination of those insect tribes which form into large and well regulated communities, and, in which new powers and instincts are seen

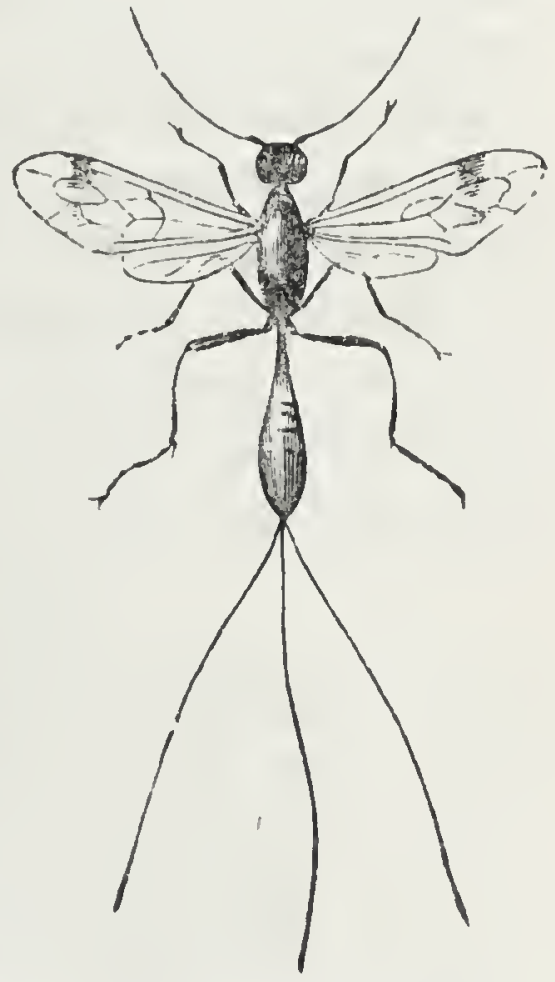

Fig. 68.-ICHNEUMON. at work. Among these are the Ants; and it may perhaps seem strange that the little, busy, wingless creatures which we see foraging about our fields and gardens, with ceaseless activity, should be included 
among insects having four membranous wings. But, if an Ant's nest be examined towards the end of summer, numbers of them will then be found possessed of wings. These are young Ants, which have just assumed the perfect state. The males and females rise together into the air; the males soon perish; some of the females retire to their original home, and others, casting their wings aside, become the solitary founder's of industrious and populous cities. It is the business of the neuters to build storehouses, to make highways, to nurse the young grubs, to cater for all, and perform many other offices essential to the well-being of all the inhabitants of the nest.

The fact that our Ants pass the winter in a torpid state is contrary to popular belief. The prevailing notion is, that during the summer and autumn they carefully lay up a stock of provision for the winter, one end of each grain being carefully bitien off, in order to prevent it from growing. This idea is embodied in the following extract from Prior :-

"Tell me why the Ant

In summer's plenty thinks of winter's want?

By constant journey careful to prepare

Her stores, and bringing home the corny ear-

By what instruction does she bite the grain?

Lest, hid in earth, and taking root again,

It might elude the foresight of her care."

The error, in this instance, had probably arisen from the Ants having been observed carrying their young about in the state of pupæ, at which time they bear some resemblance, both in size and shape, to a grain of corn; and it would receive confirmation from their 
being occasionally seen gnawing at the end of one of these little oblong bodies-not to extract the substance of the grain, nor to prevent its growth, but in reality to set the enclosed insect free from its confinement.

The fact that no European species of Aut stores up grain, no way affects the lesson which Solomon so beautifully teaches,_-"Go to the Ant, thou sluggard, consider her ways and be wise; which, haviug no guide, overseer, or ruler, provideth her meat in the summer, and gathereth her food in the harvest." Even if the insect did not collect a supply of food for future use, we might all, with great advantage, " consider her ways and be wise." But it is more than probable that Solomon referred to species living in a warmer climate, and, consequently, different in modes of life from those which are natives of these countries. This view is strengthened by the discovery made by Colonel Sykes, of a species living in India, which hoards up in its cell the seeds of grass, and takes the precaution of bringing them up to the surface to dry, when wetted by the heavy rains peculiar to the country.

The Wasps constitute another tribe of Hymenopterous insects. Their community consists of males, females, and neuters. The males and females are produced only towards autumn; the males and neuters die as the season advances; and each of the widowed females who survives comes forth in spring, a solitary being, to establish another city not less populous than that which has perished.

It is a singular fact that the nests of these insects are made of a material which we are apt to regard as a modern invention-paper. With their strong jaws 
they cut or tear off portions of woody fibre, reduce it to a pulp, and, of the papier mache thus made, the cells, and often the covering of their habitations, are formed. The exterior of the tree-nests of some of the foreign species is perfectly white, smooth, and compact, resembling, in appearance the finest pasteboard. The nest of our common Wasp is less attractive; but when it has been carefully dug out of the earth, and the interior laid open to view, with its ranges of cells skilfully supported upon suitable pillars, the regularity and perfection it displays cannot be contemplated without feelings of surprise and admiration.

Some Bees are solitary and some are social, their habits in this particular resembling those of the Wasps. Among the solitary Bees some are known as ma-

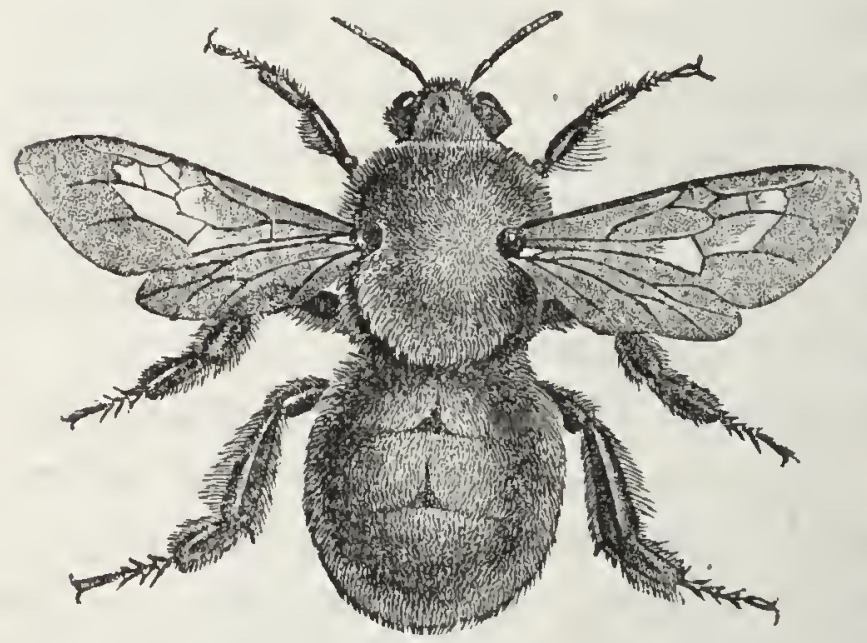

Fig. 69.-Bombus or Humbie BeE. sons, carpenters, or upholsterers, according to the nature of their labours and the materials with which they work. The social Bees have, in each community, three kinds of individuals-males, females, and workers or neuters; and, among other peculiarities, they are distinguished from the solitary species by the secretion of the wax of which the shells are made. The Humble Bees, composing the genus Bombus (Fig. 69), are known by their large size and hairy bodies, often of a black colour, with 
BEES.

orange bands. They form societies, consisting of about fifty or sixty individuals, and occasionally amounting to two or three hundred.

The Hive Bee is, however, the species to which, above all others, our interest attaches; the accompanying figures of the drones and workers (Figs. 70, 71) convey an idea of their difference in regard to size and

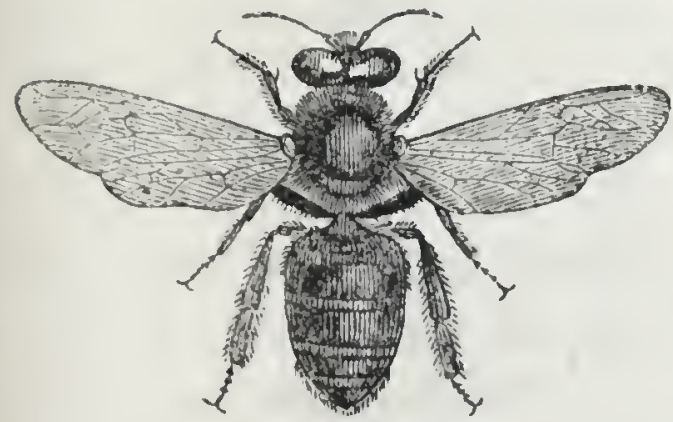

Fig. 70.-Drone BeE.

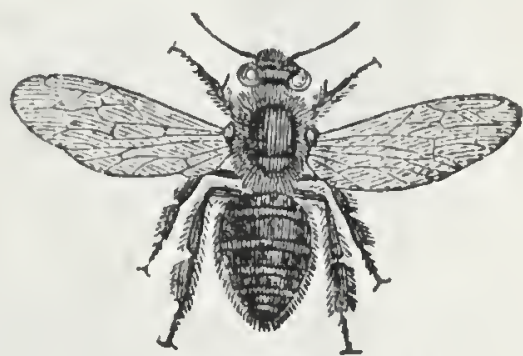

Fig. 71.-WORKEIR BFE.

form. The one female, to which we give the name of queen, had always the title of king applied to her by the ancients. Her course, when she pleases to travel through the hive, is a royal progress; her affectionate subjects offering her honey, attending on her steps, and doing everything in their porver to testify their love and obedience.

On the workers the business devolves of collecting honey and pollen, constructing cells, tending the young, and performing the various duties which the common welfare demands. The drones or males take no part in the labours of the hive; and when the continuance of the community is secured, they are dragged forth in the antumn, and mercilessly stung to death by the workers.

The tongue of the Bee (Fig. 72) is furnished with numerous muscles, and protected by sheaths when not 
in use, yet fitted for being instantly' unfolded, and

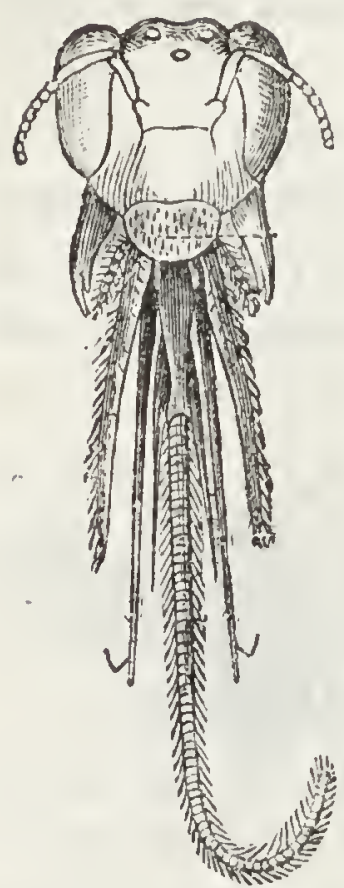

Fig. 72.

ToNgue of BeE. darted into the blossoms of a flower. The nectar thus swept up is at once consigned to the honey-bag. This being done, the tongue is sheathed with the same rapidity, part being drawn back into the mouth, and the remainder doubled up under the chin and neck, until again required.

The little pellets which we see the Bees carrying home on their hind legs consist of the pollen or farina of flowers. Shakespeare has, therefore, given utterance to the common, but incorrect idea, when he uses the words-

"Our thighs are packed with wax."

The pollen, when brought home, is mixed with honey, and forms what is called Bee-bread. The wax itself is not collected from flowers, but is gradually formed by means of peculiar organs, which may easily be seen by pressing the hinder portion of the body. It is not a secretion which is constantly going on, but takes place only when required for the construction of comb. To supply it, the wax-workers, which are distinct from the nurses, are obliged to feed on honey and remain inactive, generally hanging in clusters from the top of the hive for about twenty-four hours before the wax is deposited. 


\section{ORdER V.-BEE-PARASITES.}

STREPSIPTERA (TWISTED-WINGED).

This order consists of only a single family (Fig. 73). The individuals composing it are, in their perfect state, short-lived, delicate creatures. Their size is small, not exceeding a quarter of an inch. They, feed and pass the early stages of their existence in the bodies of Bees and Wasps, especially in those of different species of Fig. 73.-Struops (Magnified). solitary Bees. Entomologists are not agreed as to the true position of these remarkiable insects, and some would place them with the Coleopterc.

\section{Order Vi.-BUTterflies, \&o.}

\section{LEPIDOPTERA (SCALE-WINGED).}

The wings are four in number, large, extended, covered on both sides with minute scales, overlapping each other like the slates on the roof of a house, and on their removal showing that the wing itself is formed of membrane. There is a pretty little Moth

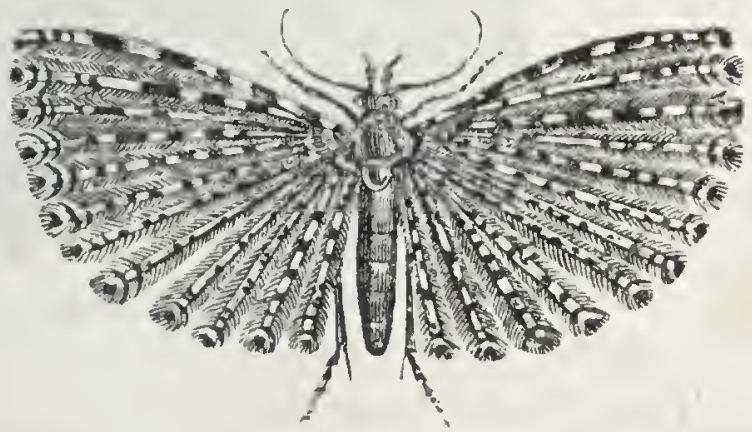

Fig. 74.-Pluand Моти (Magnified). (Fig. 74), which might, at first sight, appear to have a 
greater number of wings; but they are regarded as four wings only, cut into a number of longitudinal $\mathrm{Or}^{\circ}$ feather-shaped pieces, so as to resemble a plume or fan.

In expanse of wing and beauty of colouring they stand mmivalled. Some foreign species measure, when expanded, not less than nine or ten inches; and others display tints so splendid that they have been compared to those of gems and flowers.

Even in those which are natives of our more northern clime considerable variety exists. Some are scarcely distinguishable from the leaves of the plants or trees on which they repose; others vie in purity with the snow-flake. Some exhibit brilliant hues like those of metals, and others an azure like that of a summer sky at noon.

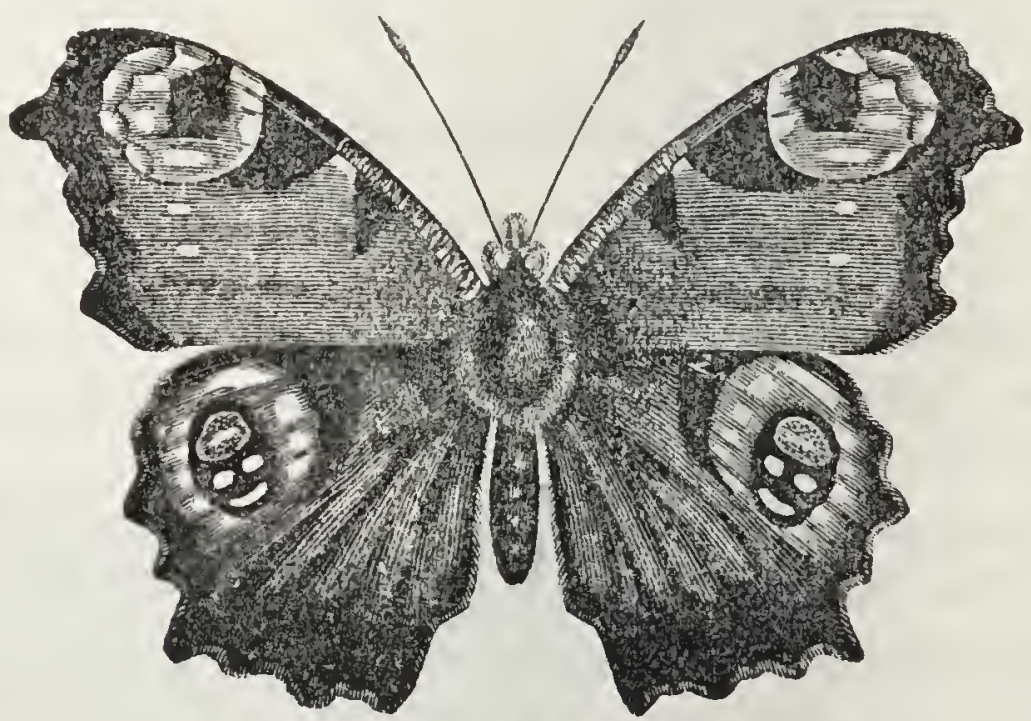

Fig. 75.-Peacock Butterfly.

They have been divided, according to the times of their appearance, into those that fly during the day, those that appear in the twilight, and those that come 
forth at night. These three groups are popularly known as Butterflies, Hawk-motlıs, and Moths.

Many of the most splendid British Butterfies are not found in Ireland; and several species-as, for example, the Peacock Butterfly (Fig. 75)-are taken in the south of Ireland, but are quite unknown in the north. Hence, as certain kinds have but a limited range, each change of place brings fresh objects of interest before the eye of the naturalist; and as the appearance of different species is periodical, a similar. pleasure is connected with each change of season.

Those of the second group, which fly most generally in the cool of the morning or evening, have the swiftest and most powerful flight; hence the name Hiawk-moths (Fig. 76). They are also called Sphinxes, in consequence

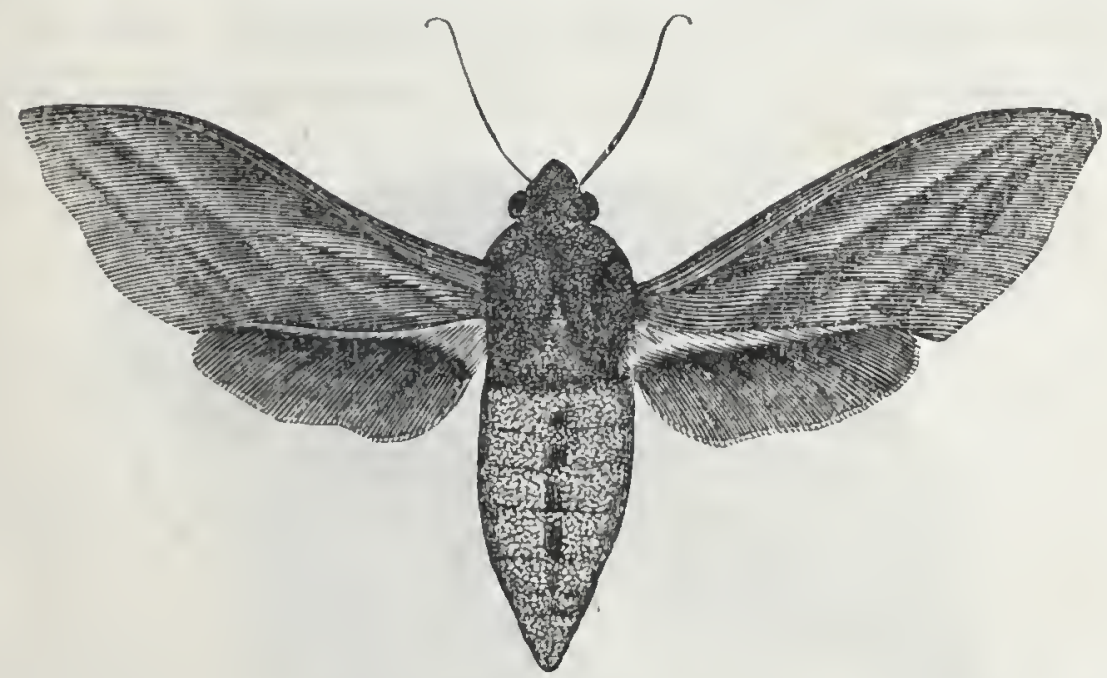

Fig. 76.-SPHNX of the VINE.

of the head of the Caterpillar being held erect, so as to give it some resemblance to the attitude of the Egyptian Sphinx. Some of the tribe come forth in the brightest sunshine, and have obtained the name of Hummingbird Hawk-moths. One very remarkable, both for its 
size and markings, is the Death's-head Moth, the largest of all European species. By the ignorant it has always been regarded with superstitious terror, as the forerunner of war, pestilence, and famine.

The remaining tribes are all included under the

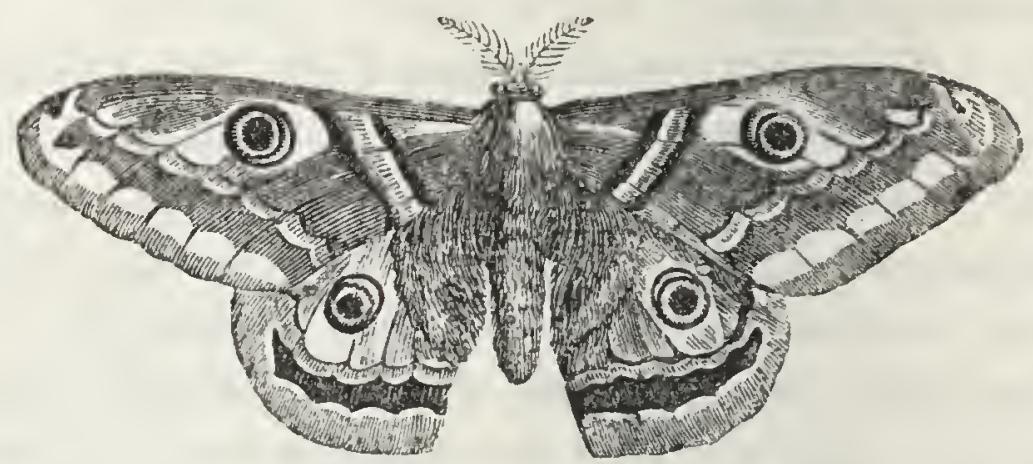

Fig. 77.-EMPERor MOTH.

common name of "Moth." This word is sometimes used to express the extreme of littleness. To show how wrong is this idea of their extremely small size,

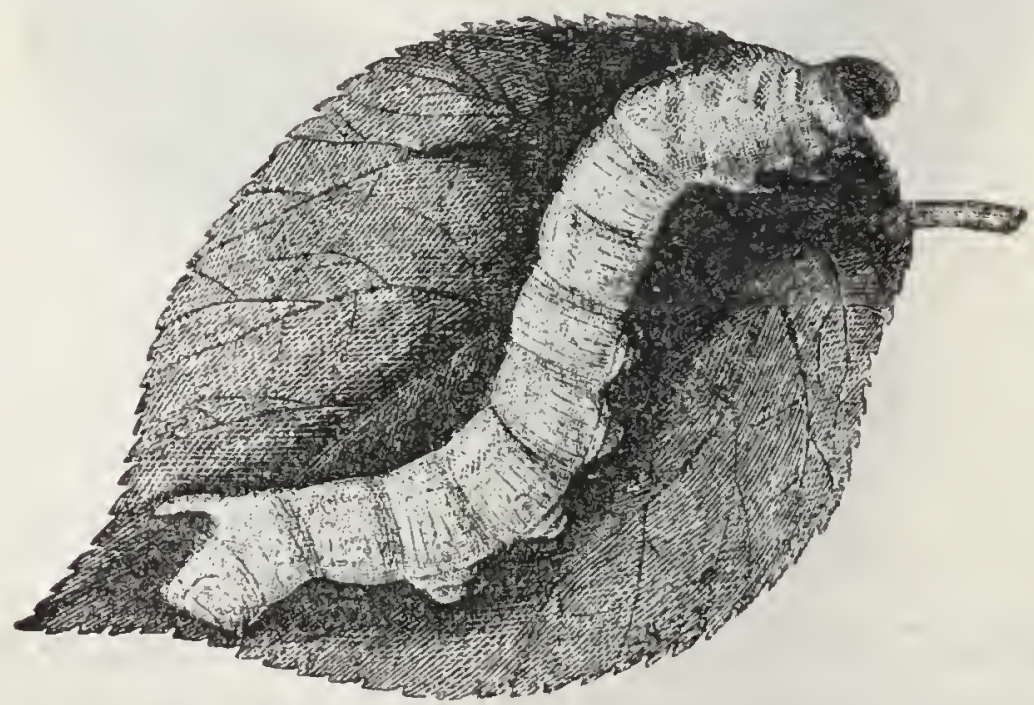

Fig. 78.-SilkwORנr.

it is only necessary to mention that the Oak-moth measures three inches and ithalf across the expanded 
wings, and the Emperor Moth (Fig. 7 7 ) is equally large.

There is one insect belonging to the present order which may be said to influence the habits and employments of many hundred thousands of human beings; it is the Silkworm Moth (Fig. 80), whose caterpillar (Fig. 78) spins the cocoons from which silk is manufactured. There was a time when this article, now so abundant, was valued in Rome at its weight in gold, and the Emperor Aurelian refused his Empress a robe of silk because of its dearness. At that very period the Chinese peasantry, anounting in some of the provinces to millions in number, were clothed with this material; and both there and in India it has formed, from time beyond the memory of man, one of the chief objects of

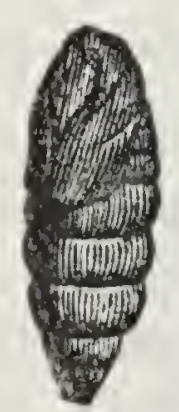

Fig. 79.-ChrYSALIS of Sictitorir.

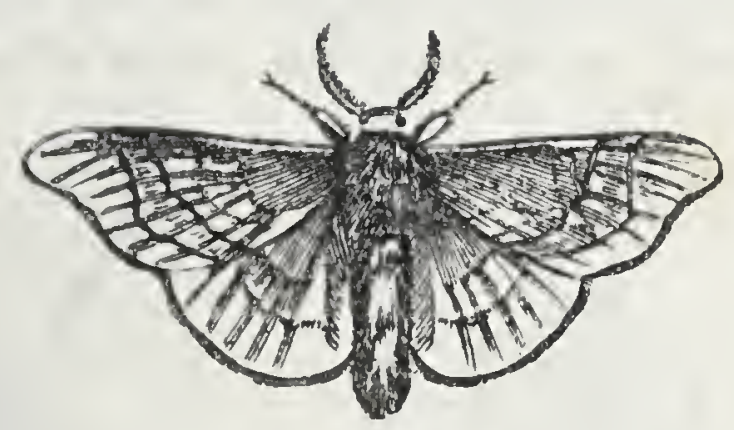

Fig. 80.-Silкworm Мотн.

cultivation and manufacture. About the year 550 the eggs were brought to Constantimople, thence they were introduced into Italy, and in the sixteenth century, under the auspices of Henry IV. of France, the cultivation of silk was commenced in his dominions. In its various states it now forms, in many parts of the world, a branch of manufacture and commerce of great 
extent and importance; hence it has been justly remarked, that, when Nature

"Set to work millions of spinning worms, That in their green shops weave the smooth-haired silk, To deck her sons,"

"she was conferring on them a benefit scarcely inferior to that consequent upon the gift of wool to the fleecy race, or a fibrous rind to the flax or hemp plants."

\section{Order VII.-CICADE，BUGS，\&c.}

\section{HEMIPTERA (HALF-WINGED).}

Is the insects belonging to this order the mouth is formed for sucking the juices of animals or plants

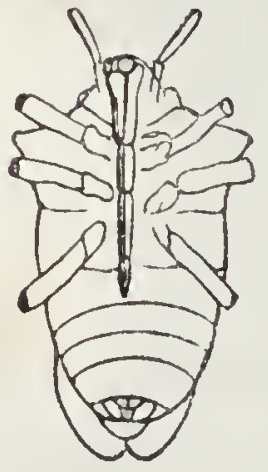

Fig. 81.-Pentatoma (Lower Surface).*

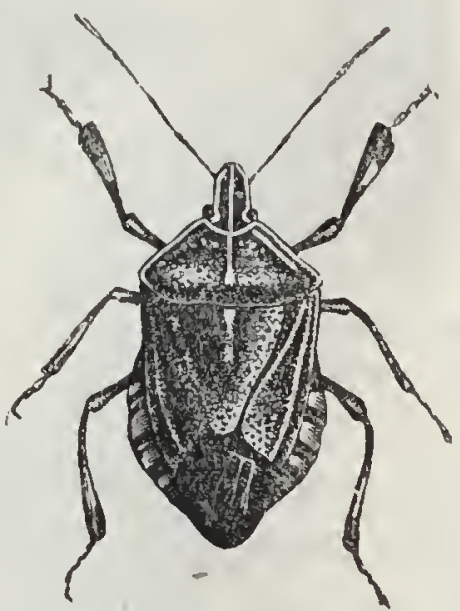

Fig. 82.-HALYS

(Upper Surface).

* This figure exhibits the shape and jointed structure of the proboscis, and its position when not in use. The legs and antennæe are represented as cut off near the base. 
(Fig. 81). The wings are four in number, partly overlapping each other, and with the portion towards the base of each tougher than the other part, which is formed of membrane.

In this order is included the Cicada (Fig. 83), celebrated for his song, and whose images, made of gold, were formerly worn by the Athenians in their hair.

Every pond affords examples of other insects whose structure exhibits, still more plainly, the characteristics of the order. There we find the Boat-fly (Fig. S4), which rows gracefully along upon its back; and the Water-scorpion (Nepa, Fig. 85), in which the dark external covering of our most common native species contrasts beautifully with the'scarlet body underneath; and others which

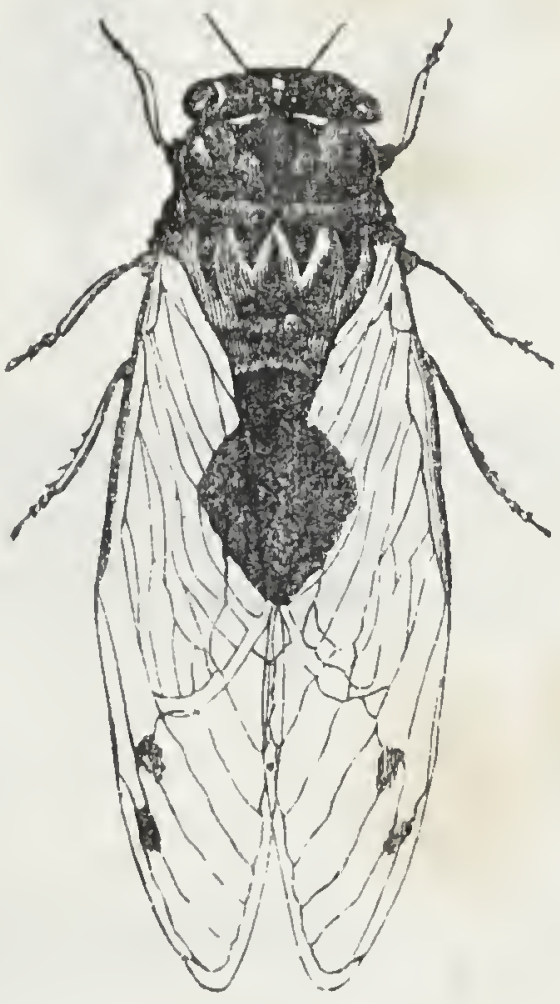

Fig. 83.-Cic.1DA. glide rapidly along, or perform a more unusual featthat of walking upon the surfice of the water.

'To the present order belongs one insect, universally regarded as a very disgusting visitant, - the Bed-bug (Fig. 86). This creature would appear to be much more common now than in the days of Queen Elizabeth; for, although Shakespeare mentions several insects in lis plays, and the word "Bug" occurs five or six times, it is never applied to the insect, but is always used 
as synonymous with bugbear. It is without wings, differing in this respect from some of those (Figs. 81,

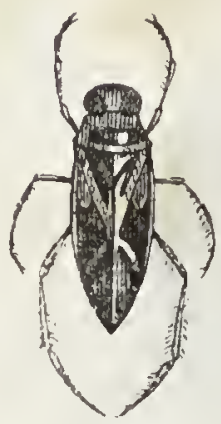

Fig. S4.-BOAT-FLY.

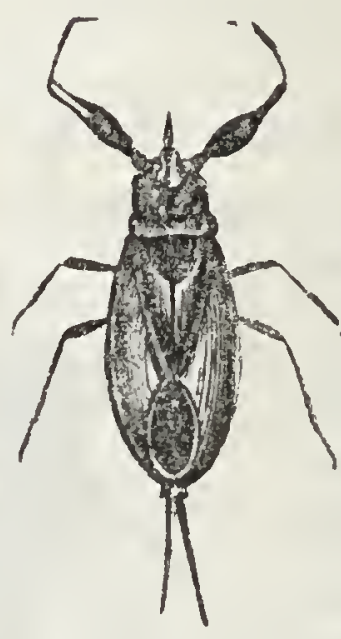

Fig. S5.-NEPA.

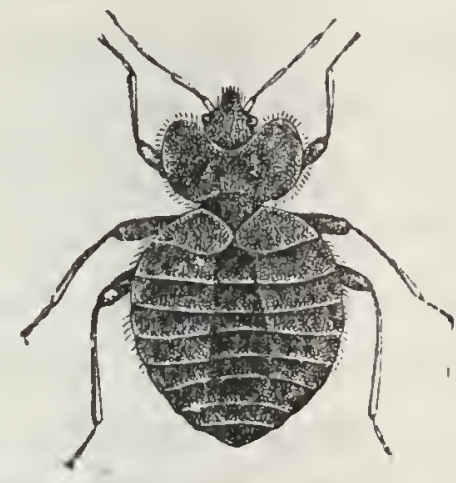

Fig. 86.-BED-BDG (Magnitied).

82) which feed on the juices of plants, and are sometimes of large size and brilliant colours.

Order VIII.-FLIES, GNATS, \&c.

\section{DIPTERA (TWO-WINGED).}

'This order' consists entirely of two-winged Flies. The wings are membranous. The mouth is formed for suction; and in certain tribes, such as the Gnat (Fig. 87) and the Gad-fly (Fig. 88), it is furnished with lancet or razor-shaped organs, to enable it to pierce the skin.

The larvæ of some species live in the most disgusting substances, and speedily effect their removal. 
Among these are Flesh-flies, whose office it is to feed on and thus remove the dead and decaying bodies of animals, which soon would taint our atmosphere. They are gifted with wonderful powers for effecting this olject. The young are bronght forth alive, and the female will give birth to twenty thousand young. Hence the assertion of Linnæus, with regard to one

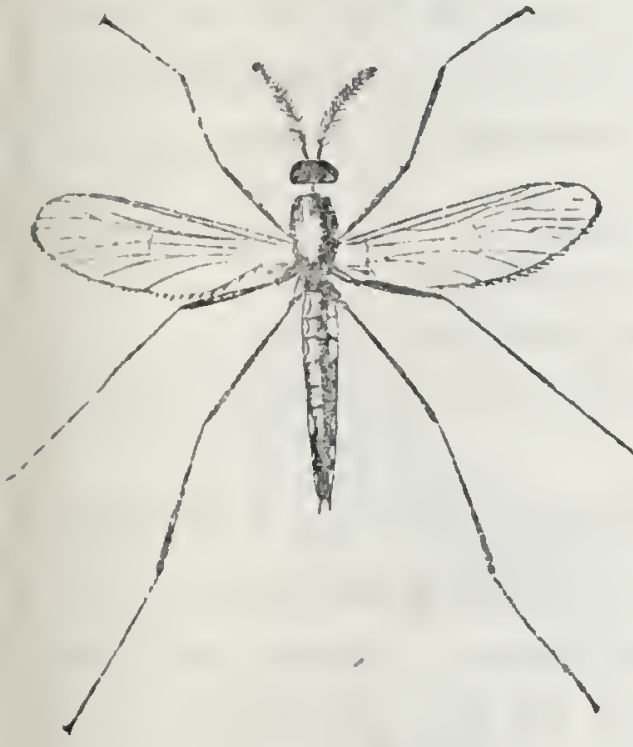

Fig. 87.-Gnat (Magnificd).

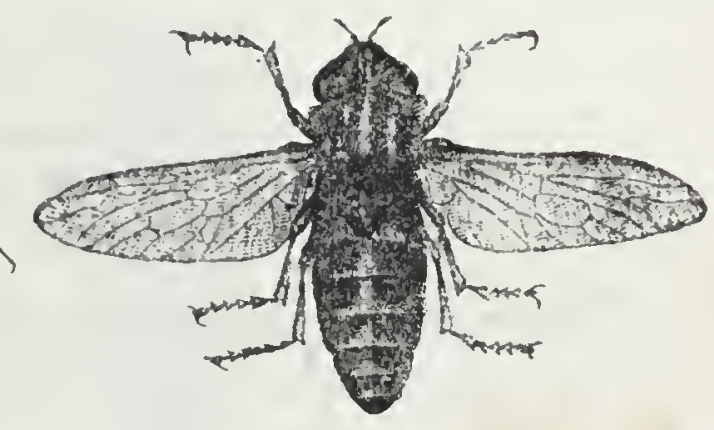

Fig. S8.-GAD.FLY.

species, that three of these Flies would devour a dead Horse as quickly as a Lion would do, is perhaps not much overstrained.

These insects must, lowever, be regirded in another light-as the tormentors of man instead of his benefactors. According to Arthur Young, Flies-that is, the common Honse-flies-constitute "the first of tor"ments in Spain, Italy, and the olive districts of France. Your mouth, eyes, ears, and nose are full of them; they swarm on every eatable; fruit, sugar, milk, everything is attacked by them." The annoyance occasioned by the Mosquito is noticed by every traveller in the 
southern parts of Europe and the northern parts of Asia and America. Dr. Clarke states, in his journey along the frontier of Circassia, that the Cossack soldiers "pass the night upon the bare eartli, protected from the Mosquitos by creeping into a kind of sack sufficient only for the covering of a single person." Nor do our donestic animals escape; the sufferings of our Horses from the attacks of Gad-flies are well known, and we have all seen a group of Oxen in summer standing in a stream, in the circumstances described by Thomson,-

"In the middle droops

The strong laborious $0 x$, of honest front, Which incompos'd he shakes; and from his sides

The troublous insects lashes with his tail, Returning still."

There are tribes of two-winged insects which delight in the companionship of their fellows, and have long been celebrated for their aërial dauces. Every one has observed how those belonging to the family of the "Harry Long Legs," and others spoken of as "Midges," appear in multitudes-

\section{"And weave}

Their sports together in the solar beam, Or in the gloom of twilight hum their joy."

\section{Order IX.-WINGLESS INSECTS.}

\section{APTERA.}

Is this order were formerly included many articulated animals, which are now transferred to other orders, and 
even to other classes; of late it has consisted of Springtails (Fig. 89) and the parasitic insects which infest man (Figs. 90, 91), quadrupeds, and other animals. Even this arrangement is gradually giving way, and those insects are remored to other groups. A difference of opinion still prevails as to the best classification. Thus, some Entomologists place the Flea in an order which they term Aphaniptera; while other's consider that it should be associated with the two-winged Flies, being,

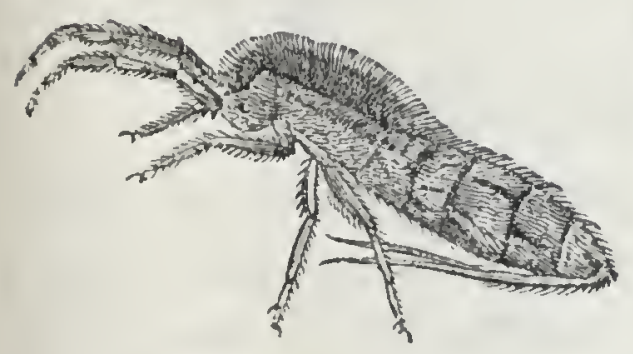

Fig. S9. - SPRING-TAII.

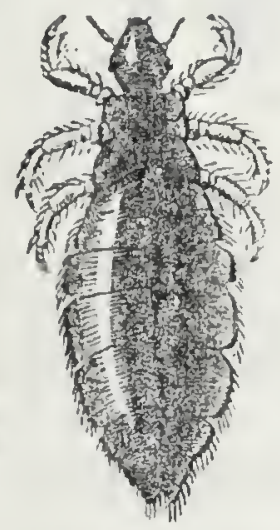

Fig. 90.-Louse.

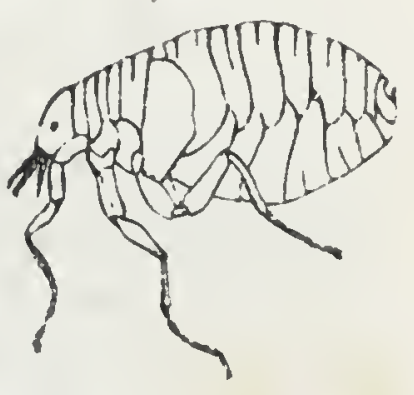

Fig. 91.-FleA.

in all essential points, a dipterous insect, but wanting the wings. It is probable that the old Linnæan term, Aptera, will erelong cease to indicate a distinct group of insects.*

* If this expectation be fulfilled, if the Strepsiptera (p. 83) be united to the Coleoptera, and the Orthoptera (p. 71) to the Hemiptera, the number of orders will then be reduced to six, viz., Coleoptera, Neuroptera, Hymexoptera, Lepidoptera, Hemiptera, and Diptera. 


\section{CLASS VIII.-SPIDERS.}

ARACHNIDA.
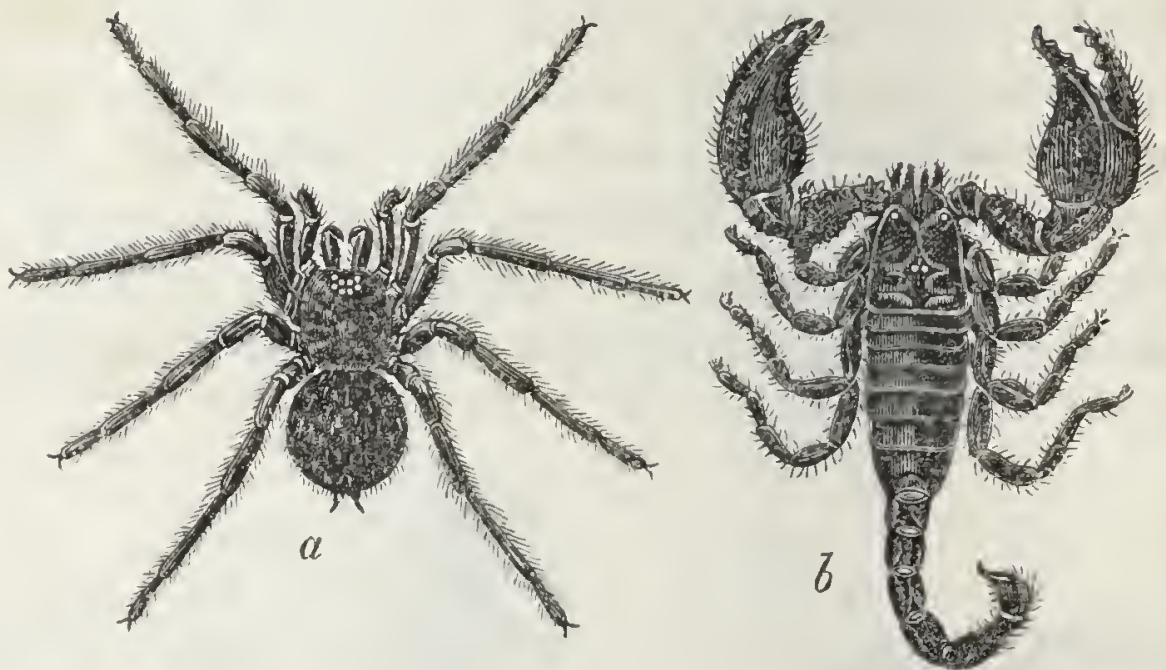

Fig. 92.-SeIder and Sconyion.

Spiders, Scorpions, and Mites belong to the present class. They do not, like insects, undergo changes of form, and some among them breathe, not by tubes, but by lungs. They differ from the true insects, also, in having eight legs instead of six. The eyes vary in number and position, but are always simple.

All Spiders secrete a poisonous fluid, which is fattal to insects, but produces little effect on the human frame. The poison is conveyed through a hollow fang in the mandibles or jaws. In the Scorpion (Fig. 92, b), on the contrary, it is lodged at the end of the slender. flexible tail, and the wound is inflicted by the sting by which the tail is terminated.

. That any creature could be found to form a net not less ingenious than that of the fisherman, for the capture of its prey; that it should fix it in the right place, and then patiently await the result, is a proceeding so 
strange, that if we did not see it done daily before our eyes by the common House-spider and Garden-spider, it would seem wonderful. But how much is our wonder increased when we think that each single thread is made up of above a thousand threads still more delicate; so that, even when it is so fine as scarcely to be visible to our eyes, it is not a single line, but is in reality a rope composed of more than a thousand strands. This is known by counting the number of little teats at the hinder extremity of the body, whence the threads proceed, and examining the multitude of minute openings, of which each of them is composed. Add to this, as an cxample of the wonders which the most common things exhibit when carefully cxamined, the net of the Garden-spider consists of two distinct kinds of silk. The threads forming the circles are composed of a silk much more elastic than that of the iays; and are studded over with minute globules of a viscid or sticky gum, sufficiently strong to hold any unwary fly which may touch it. In ordinary circumstances the threads lose their viscidity by exposure to the air, and require to have it renewed every twenty-four hours. Any observer, by scattering a little fine dust over the web, may satisfy himself that it is retained only on the circles where the minute globules are placed, and not upon the lines which come from the centre to the outer edge of the circle. The nets of some Spiders are constructed under water, the material of which they are formed not being liable to be melted by it, and they are spread out for the capture of the insect in habitants of the pool.

A great deal of false pity has bcen bestowed upon 
the Flies which fall victims to the voracity of the Spider, who has accordingly been regarded as "Cunning and fierce: mixture abhorred." But, considered aright, there is no cruelty in any animal exercising, for its support, those powers with which it has been endowed by its Creator. It does not kill for sport, but from necessity. It must kill, or it must cease to live.

Spiders have been divided into families, which present very considerable differences in their modes of life and in their habitations. The Mygale forms a tube or gallery in the earth, lines it with silk, and constructs a door formed of several

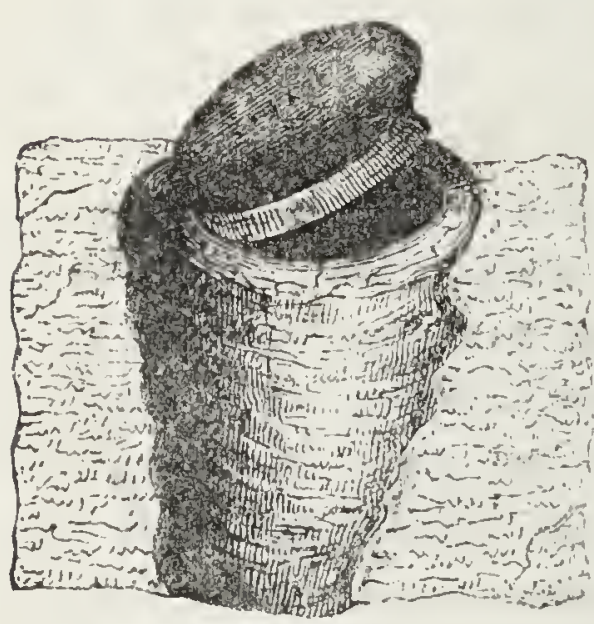

Fig. 93.-Nest of MrgaLe. coats of cemented eartli and silk. "This door (Fig. 93) the ingenious artist fixes to the entrance of her gallery by a hinge of silk; and, as if acquainted with the laws of gravity, she invariably fixes the hinge at the highest side of the opening, so that the door, when pushed up, shuts again by its own weight." The part against which it closes, and the defences by which it is secured, are not less excellent as skilful contrivances than those of our engineers or mechanics. The Cheese and Sugarmites, the beautiful Red Water-nites, so common in many of our pools, with other creatures not quite so well known, which inhabit the sea, offer further examples of the class before us. 


\section{MOLLUSCA.}

\section{SOFT-BODIED ANIMALS.}

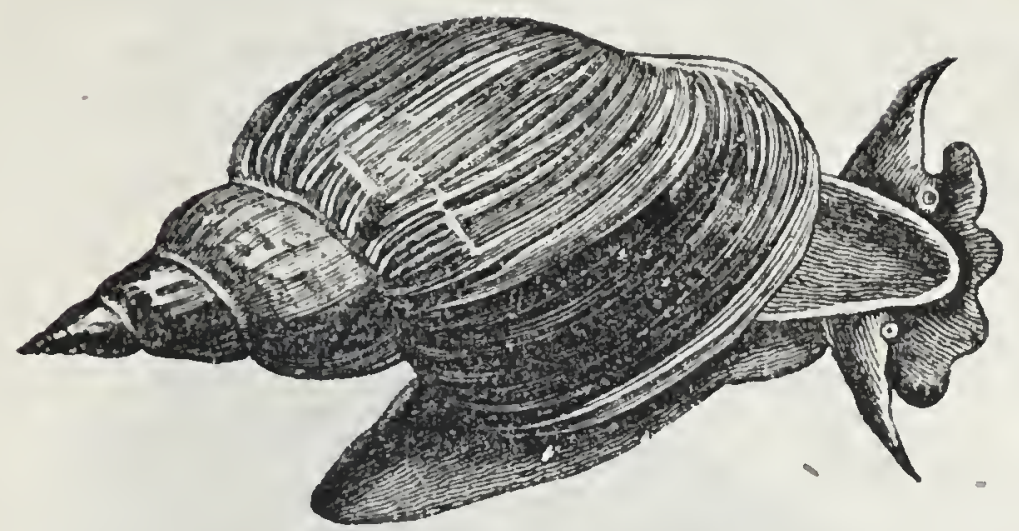

Fig. 94.-Linnges Stagmalis.

'THe soft-bodied animals to which the term Mollusce is applied constitute another of the primary groups of the animal kingdom. In them we see no longer the jointed structure which is so strikingly displayed in the preceding division. The arrangement of the nerves is also different.

The beautiful variety of form observable in the shells

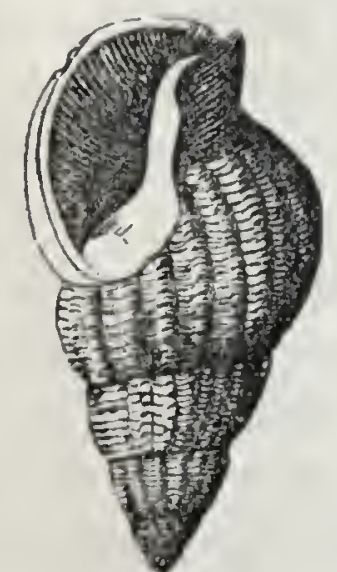

Fig. 95.-Buccrivur.

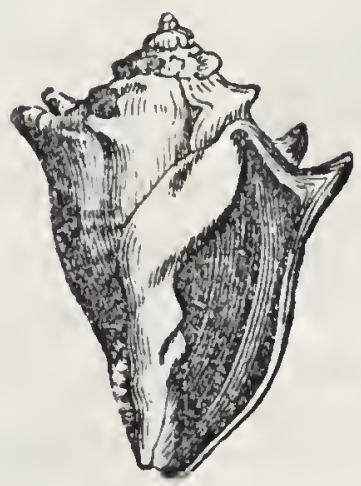

Fig. 96.-VoLUTA.

of different species of Mollusca (Figs. 95, 96, dc.) has, in all ages, attracted attention; and the splendour 
of their colouring is not surpassed by that of our brightest garden flowers. In some respects it is even superior; for their most delicate tints become here unfading and permanent, and a peculiar structure of the surface gives rise occasionally to rainbow lues. Among savage tribes shells are formed into ornaments, and applied to numberless uses.

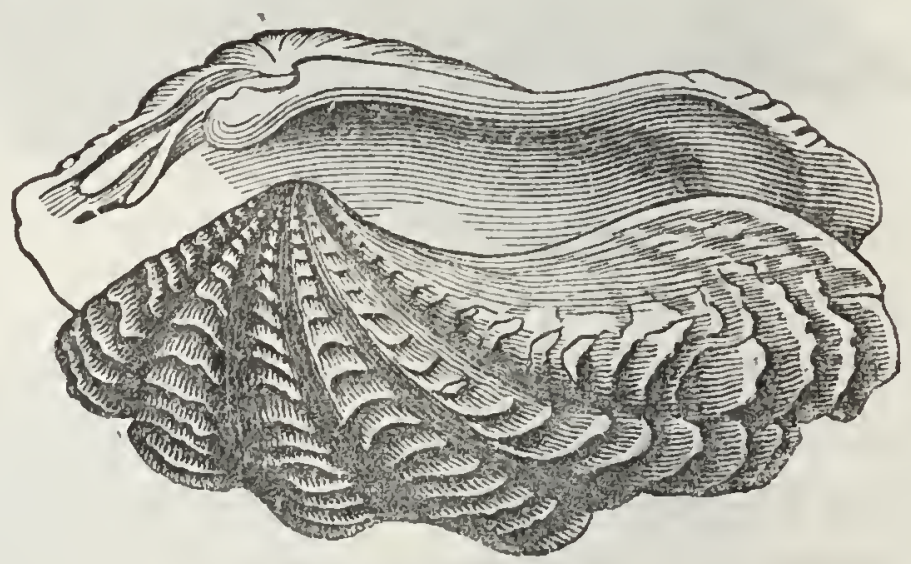

Fig. 97.-TRidacya.

The difference in point of size is not less remarkable than that of the form and colouring. The Tridacna, or Giant Clamp-shell (Fig. 97), is said to attain

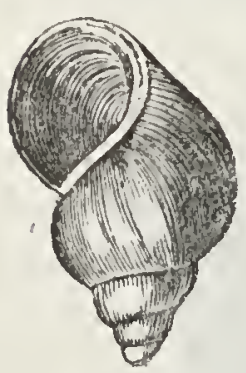

Fig. 98.

Rissoa Ulve occasionally a weight of more than 500 pounds; from which circumstance the story may have originated of an Oyster which furnished a dinner to a whole regiment. Let us, in imagination, contrast with this the minute shells of a common species (Rissoa Ulve, Fig. 98) found on (Enlarged). our coasts, 2,000 of which, together with their contained animals, would scarcely exceed an ounce in weight.

The Mollusca are divided into seven Clässes, viz. :- 
Class 1.-POLYYOA, Sca-mosses.
"2.-TUNiCata, Tunicates.
"3.-Brachrorona,............... Lamp Shells.
"4.-Ianuldibiaciiata, ..... Divalves.
"5.-PTeropon a, ..................Pleropods.
"6.-Gasteroroph,.............. Univalves and Slugs.
"7.-CEphaLOP(I)A, Cuttle-fishes and Nautili.

A distinct heard is present only among the members of the three lisst classes, which are on this account often spoken of as Encephala (that is, head-bearing). The other Mollusca are termed Acephala (or headless).*

* Some naturalists arrange the Mollusca under two divisions, one of which, containing the Encephala and Bivalves, is termed "true Mollusca," the other being known as Molluscoidea.

\section{CLASS I.-SEA-MOSSES †}

\section{POLIZOA.}

THe animals belonging to this class were formerly placed among the Polypes, and, like them, were at one time regarded as true plants. But the study of their internal structure, and especially of their digestive organs, has led to their bcing removed to the present Sub-kingdom. They are of small size, and do not possess any power of motion.

As in the Polypes, the entrance to the mouth is surrounded by tentacles, each of which is beautifully fringed on either side with a row of delicate cilia (Fig. $99, b)$. These tentacles, together with the crest fiom

+ Or Bryozoa, as they are sometimes termed. The nane Folyzoa means "many animals." 
which they arise, can, at the will of the animal; be retracted or drawn back within its body, and again pushed forth when required.

Most Polyzoa inhabit the sea, others of great beauty dwell in fresh water. A group of these little creatures, growing on a submerged stone, is shown in Fig. 99 (a, natural size; $b$, one enlarged). The dried tufts of the marine species, under the name of Sea-mats and
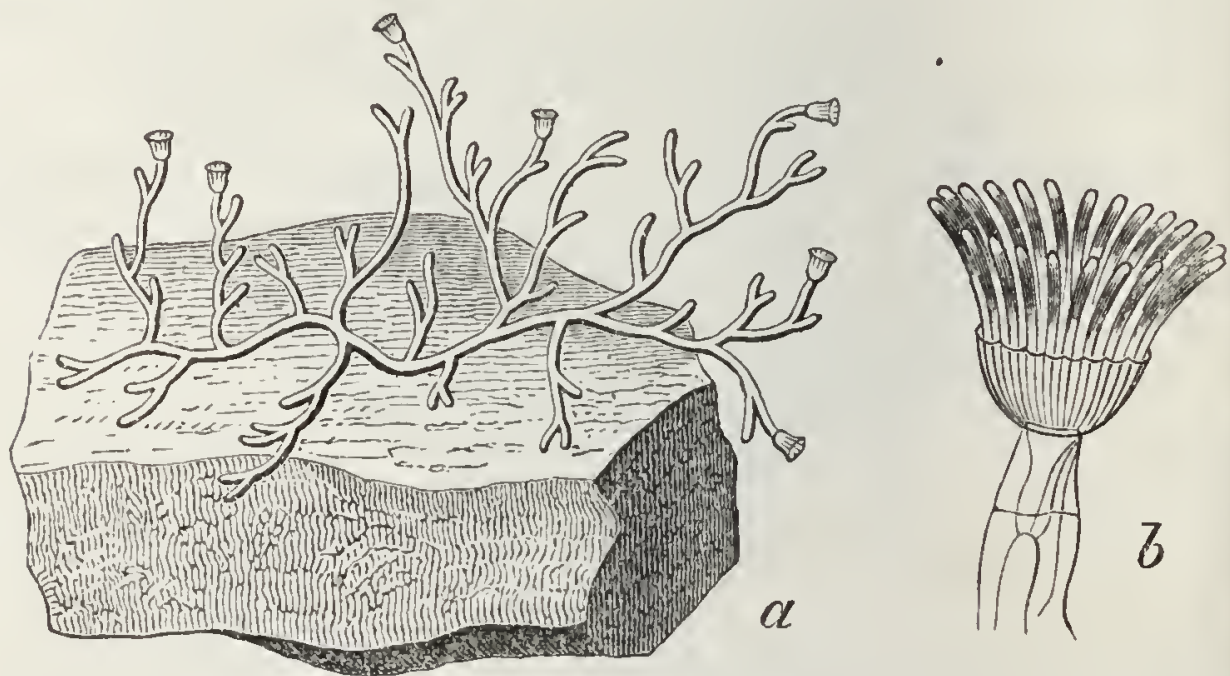

Fig. 99.-FredERICELLA.

Sea-mosses, are familiar, as they lie tossed up on the shore, to almost every sea-side visitor. Others appear as thin scaly crusts, covering the surfaces of rocks and sea-weeds.

\section{Class II.-TUNICATES.}

\section{TUNICATA.}

These Mollusks are not naked like the Slug, nor provided with a shell like the Oyster, but possess a kind of leathery covering or tunic, and are hence termed 
"Tunicated." The kind best known to our fisliermen is a solitary species about the size of the largest common Mussel, and to which, from its shape, the name of "paps" is given." The outside is darkish, warty, and unattractive, and exhibits two openings, from one of which the animal can squirt water with great force.

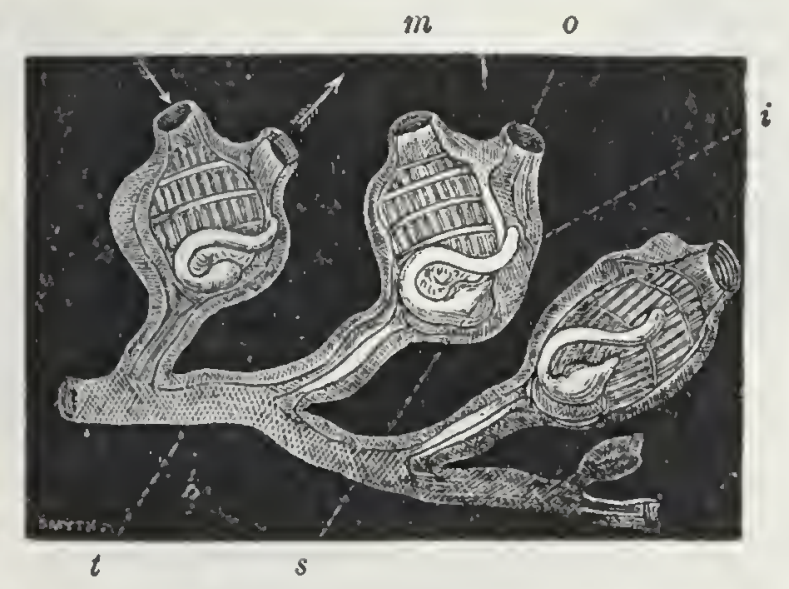

Fig. 100.-Purophora. $\dagger$

In some the tunic is coarse and leathery, in others so transparent that the organs of the body can easily be seen through it (Fig. 100).

All T'unicata are marine. In internal structure they much resemble the Polyzoa, and, like them, have no power of motion. In the warm seas of the tropics the sailor meets with several curious species of these animals, often occurring in immense numbers. These, however, have no organs for swimming, but float helplessly near the surface of the water, and some at certain times emit a very beautiful light.

- It is the Ascidia mentula. The term Ascidioida-that is, animals like the Ascidia-was formerly given to the Polyzoa. They are spoken of by that name in former editions of this little book.

+ Fig. 100. $-m$, Mouth; $s$, Stomach; $i$, Intestine; $o$, Orifice; $t$, Common Stem. The arrows indicate the direction of the currents of water subservient to respiration. 


\title{
ClaSS III.-LAMP-SHELLS.
}

\author{
BRACHIOPODA.
}

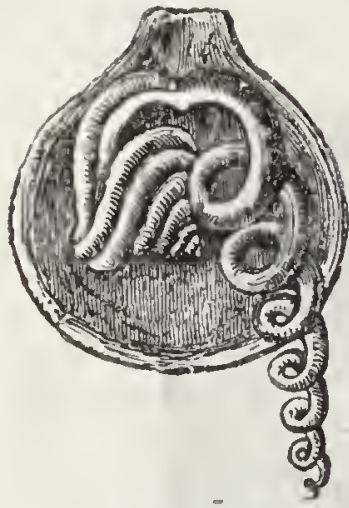

Fig. 101.-Avimat of

Terebratula Psittacea.

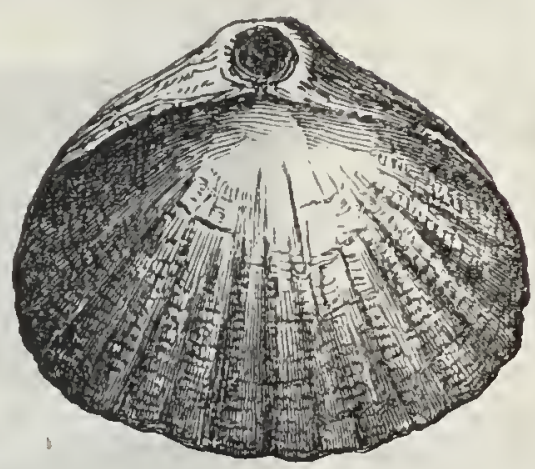

Fig. 102.-VALve of The ShFll of TeisemRatula.

Thesf Mollusks are marine, have little or no power of locomotion, and are always furnished with shells. As in the next class, the shell consists of two parts or valves, but the relation which these bear to the animals enclosed between them is not the same as in the true bivalves. Many species have been obtained by the dredge from very great depths.

The name Brachiopoda, or Arm-footed, given to these animals, refers to the pair of long fringed arms (Fig. 101) which arise from the sides of the mouth. These are much longer than the body itself, and usually lie coiled up within the shell. Less than 100 species of Brachiopoda now exist in the ocean. At least ten times that number are met with in a fossil state; while the abundance of such specimeus shows that the animals must have lived in vast numbers in the ancient seas. 
Class IV.-OYSTER, SCALLOP, MUSSEL, \&C.

\section{I.AMELLIBRANCHIATA.}

Tine last class of Mollusks without a distinct head comprises those in which the gills often occur under the form of small plates formed of membrane,--a fact which is referred to in the scientific name by which the order is distinguished. It includes the Oyster, the Scallop, the Cockle, the Mussel, and other wellknown bivalves. Most bivalves are marine; but some, as the river Mussels, inhabit fresh water. The valves are not attached to

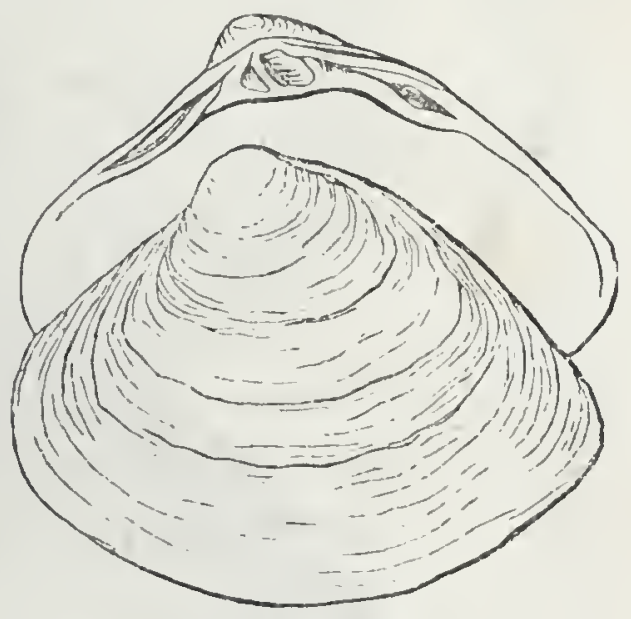

Fig. 103.-Maktra. the body in the same manner as in the Brachiopods, or Lamp-shells.

The mouth of the Oyster is situated near the hinge, beneath a kind of hood formed by the edges of the mantle or cloak which invests the body (Fig. 104). But the question naturally arises, How is it supplied with food, the animal itself being utterly incapable of any active exertion for that purpose? This object is effected by means of cilia; their action gives rise to rapid currents, which, sweeping over the entire surface of the gills, hurry towards the mouth whatever particles of nourishing matter the water contains. By this beatiful arrangement the breathing and the feed- 
ing of the animal -in other words, its respiration and nutrition-are provided for at the same time.

Shakespeare has said, "Honesty dwells like a miser in a poor-house, as your pearl in your foul Oyster;" and the connection of the Oyster with the pearl is one of the interesting circumstances connected with its history. The poet Moore has gracefully referred to the eastern fable of

"That rain from the sky

That turns into pearls as it falls in the sea."

The real facts, as at present known, are scarcely less wonderful. The shell (Fig. 105) is pierced by

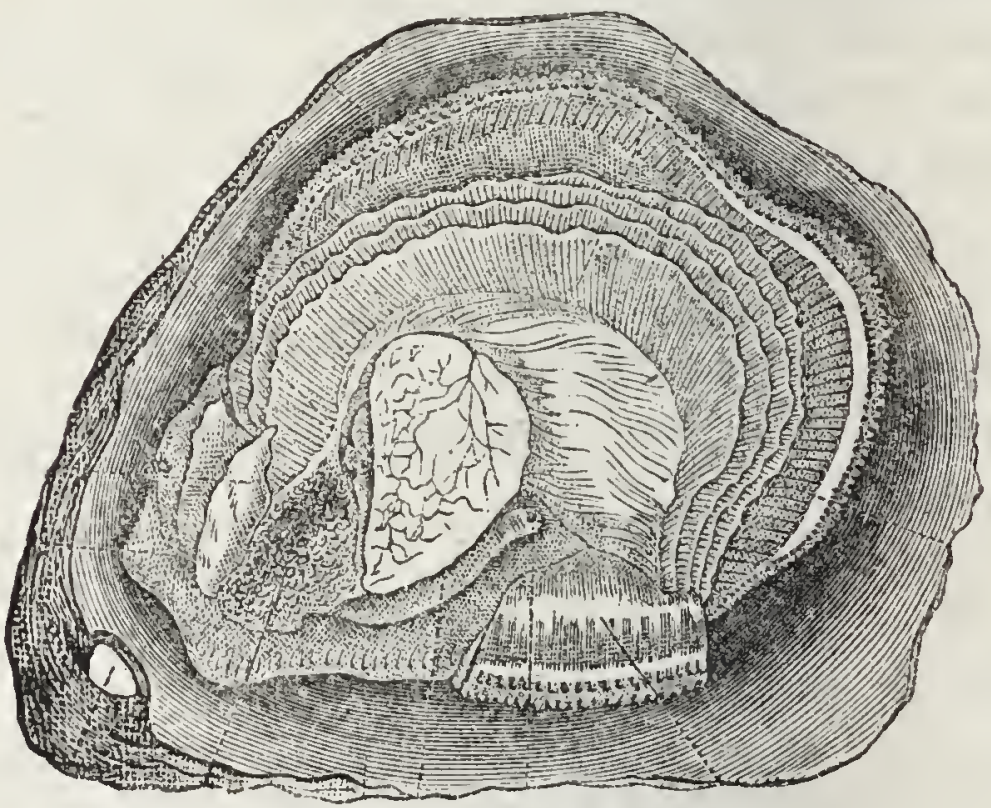

Fig. 10.1.-Anatomy of the OYstFr.

some Worm, the Oyster deposits the "nacre," or mother-of-pearl, over the entire inner surface, and more especially on the pierced part; or grains of sand or' gravel gain admission into the substance of the mantle, and become encrusted by a similar 
deposit. This would appeir to be, in many instances, the origin of the pearls, so highly prized, and still so eagerly sought for.

The common Mussel of our coasts lives moored to its "bed" by the silken cable which it constructs for this purpose. The silk which it produces is, however, much surpassed by that of the Pinna, a shell alrearly mentioned (page 5\%).

Among the Mollusks of the present class are those which

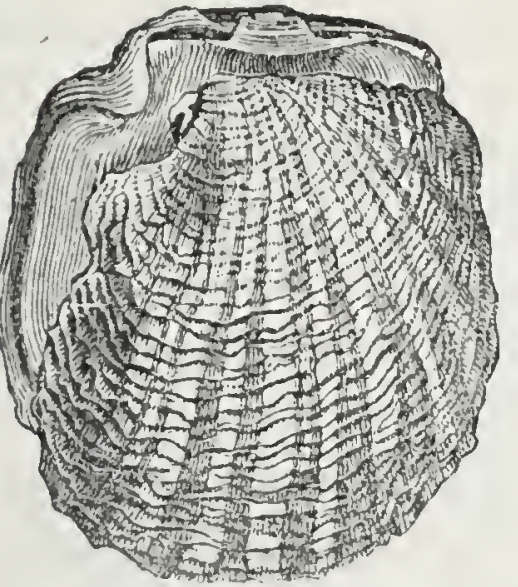

Fig. 105.-PEArL OTSTER. possess the art of boring into hard substances, and living in the cavities thus formed. The one most noted is the Tererlo, popularly known as the "Ship-worm" (Fig. 106), which, by its power of piercing or perforating wood, does great injury to ships, piers, and all submarine wooden buildings. Owing to the general use of metal sheathing-that is to say, of a covering of metal-to protect the wood from its attacks, it is now nearly extinct on the British shores.

It is occasionally the pleasing duty of the naturalist, to direct attention to some of the many examples where there springs from "partial evil universal good;" and perhaps the 'Teredo, notwithstanding the evidence of its destructive powers, might, if the whole

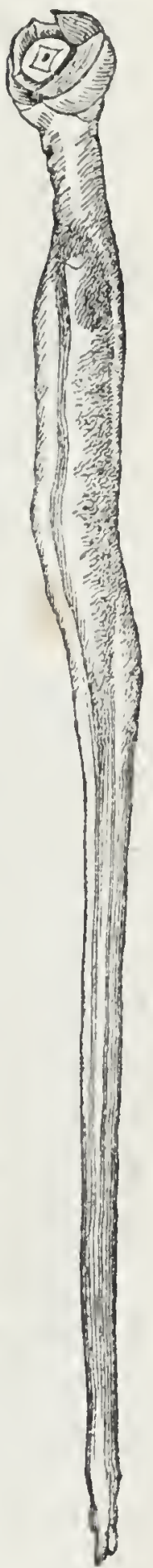

Fig. 106.

TLKEVO. 
truth were known, be ranked among the number of our benefactors. Dr. R. Ball has remarked, "that, but for the maligned Teredo, the sea would be so covered with floating logs of timber as to be to some extent unnavigable; that the rivers of warm latitudes would be choked up by the accumulated driftwood at their mouths, and that their fertile banks would in many cases be converted into morasses."

On one occasion, during a stroll along the beach, the waves flung upon the shore a piece of the painted woodwork of some unfortunate vessel. On examining it, I found that it was pierced throughout by the Teredo, and that the animals were still living in the galleries they had formed, and which were lined with shelly matter throughout all their windings. While each animal had used with effect the curious auger-shaped instrument by which the perforations were made, no one had interfered with the progress of his fellows; and almost in every instance, when the borings approached too close, their direction had been changed, and contact or interference thus avoided. That piece of drift timber, the sport of winds and waves, contained within itself a little world of animated existence.

Having now noticed the different classes of Mollusca which are without a distinct head (Acephalous), we proceed to those which have a distinct head (Encephalous). Of them there are three classes. 


\section{Class V.-PTEROPODA.}

TuE active little Mollusks belonging to this order are furnished with two expansions, like fins or wings (Fig. 107), used by the animal in swimming; and hence the compound term, which signifies "wing-footed," points out the distinguishing character of the olass. They are all marine.

A well-known species (Clio borealis) is about an inch in length, and so abundant in the Arctic seas as at times to colour

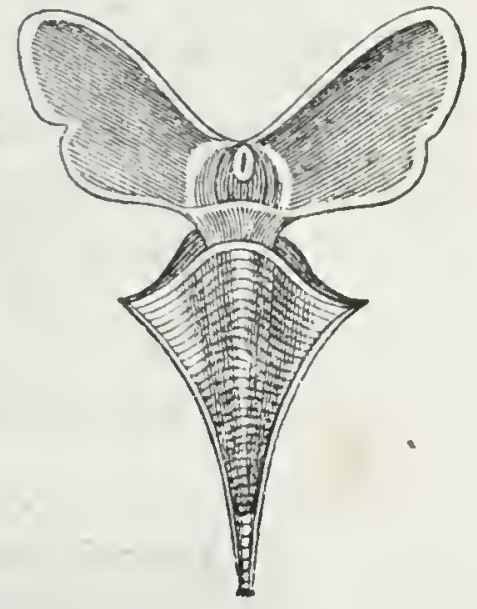

Fig. 107.-HraLAis. the surface for leagues, and to form an important supply of food to the great Whale. The head has six of the wing-like organs, which appear of a reddish tint from the number of distinct red spots scattered over their surface, and amounting on each to about 3,000. Every one of these specks, when examined under a microscope, is found to consist of about twenty suckers, each of them mounted on a footstalli, so as to be applied to their prey; so that the total numbers of suckers on the head of one of these animals is about 360,000. All of these are employed in the capture of food; and taken in connection with the hooks and teeth with which the mouth is furnished, they form an apparatus which is unequalled in the entire aninal kingdom. 
Class VI._SLUG, SNAIL, LIMPET.

GASTEROPODA.

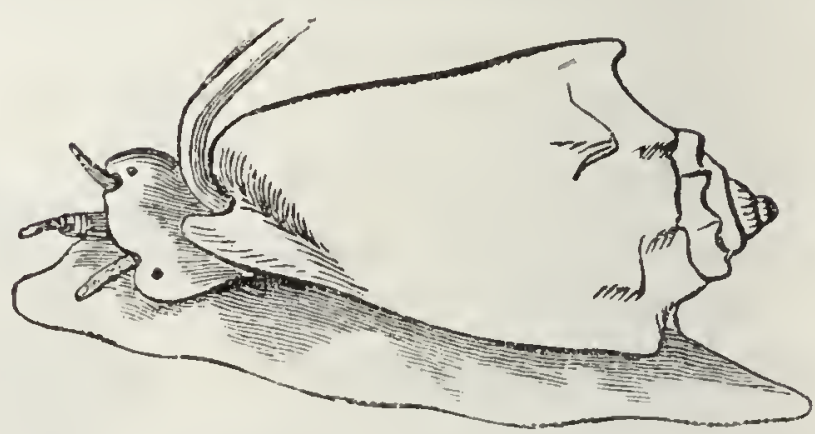

Fig. 108.-Volcta (the Animal represented in Motion).

If we look at the common Snail as it crawls along,

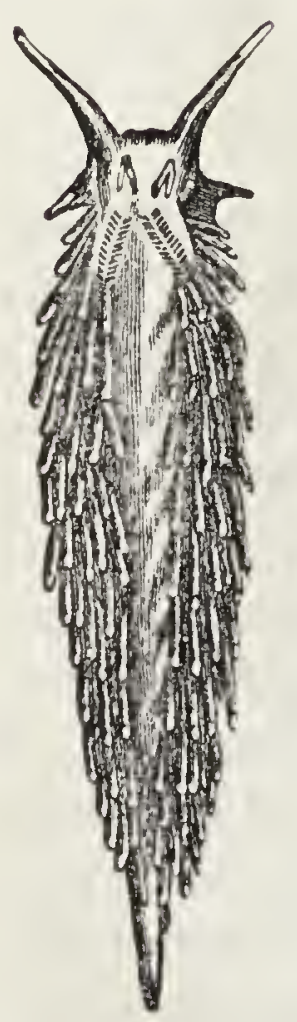

Fig. 109.-EOLIS. we notice that the only organ for motion that it possesses, instead of legs, is a broad fleshy surfice, forming the lower part of the body. Hence the compound term, Gasterópoda (belly-footed), expresses the peculiarity of its structure in this particular, and is used as the name of the class in which a similar structure prevails (Fig. 108).

The class is extremely numerous, and. is conveniently distributed into Or.ders, distinguished by various changes in the structure and position of the breathing organs. In some the gills are runcovered (Fig. 109), and arranged in various forms, and attached to different parts of the body. The animals are found upon the rocks and sea-weeds on our shore, and floating, with the foot uppermost, on the smootl surface of our bays; 
they are also dredged up from considerable depths. When placed in sea-water they exhibit figures of great delicacy, variety, and elegance, and with a beautifu] variety of colouring. Their size is very different, some of our native species being less than loalf an inch in length, while other's measure so much as four inches.

'Those species which are distinguished by haring the gills concealed under a fold of the mantle may be illustrated by reference to a creature not uncommon on our shores,-the Aplysic or Sea-hare (Fig. 110). Its

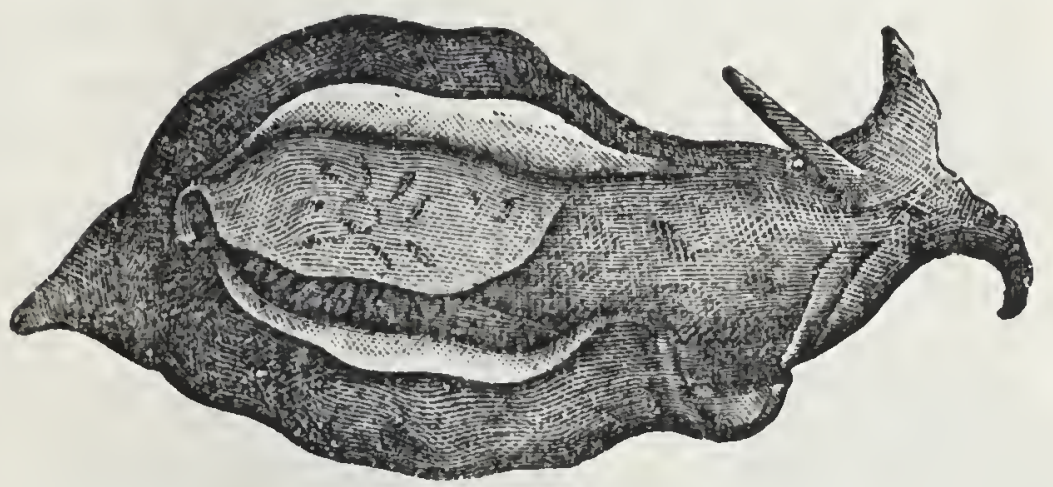

Fig. 110.-ApLTSIA.

common English name has probably been suggested by the form of the upper pair of tentacula, which present some resemblance to the ear's of a Hare. This creature, it was once believed, had so great a dislike to man, that its touch would cause the hair to fall off; and it also was said to supply a poison, the operation of which was speedy and without remedy.

Of the tribes which breathe by lungs, or air-sacs, the common Slugs and Snails offer familiar examples. Even of those species which live in water, many come to the surface to breathe, and float or move with the back downwards. The Planorbis (Fig. 111) and the 
Limneus (Fig. 94) may be thus seen on a summer's day crossing the surface of ponds and ditches, in an easy waving line, or floating there in luxurious repose, perhaps

"To taste the freshness of hearen's breath, and feel That light is pleasant and the sunbeum warm."

We might naturally suppose that the soft skin of those species which are mprotected by shells was

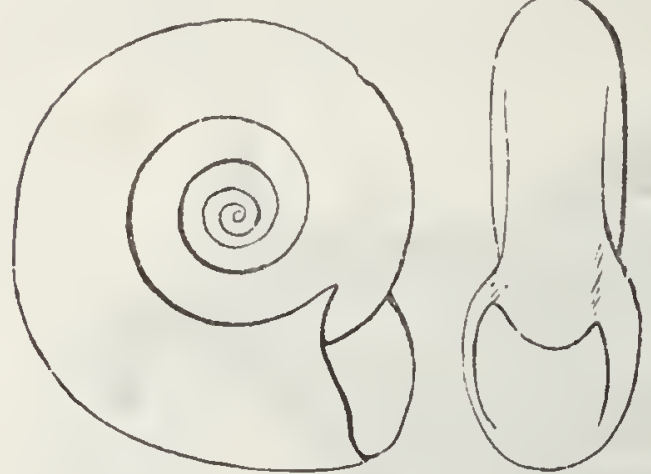

Fig. 111.-Pidanorbis. possessed of great sensibility, but such does not appear to be the case. Baron Ferussac states that he has seen Slugs allow their skins to be eaten by others, and, in spite of large wounds thus produced, slow no sign of pain. They possess, in a high degree, the power of repairing injuries, and of reproducing lost parts.

Of Snails the number of species is very considerable. A mong those which are natives of these countries are some which afford a plentiful supply of food to two of our favourite songsters, - the Blackbird and the Thrusl. Those with thin shells are, of course, the most in request, and are brought to some flat stone, and there broken to pieces. There are others which abound upon sandy slopes and hillocks; and it is a common belief that these little Snails are eaten, in vast numbers, by the Sheep which graze upon the scanty pasturage of the sandy knolls, and that they form a very fattening kind of food. 
The Helices or Snails are not, however, usd only as food for Birds, or for Sheep, and for other quadrupeds such as the Hedgehog. There is a species, found in the southern and midland counties of England, which has been considered a delicacy by man himself. From the time of the Romans, who firtened them as an article of food, they have been eaten by several European nations, dressed in various ways. Lister tells us the manner in which they were cooked in England in his time (1678). "They are boiled in spring water, and when seasoned with oil, salt, and pepper, make a dainty dish."

The common Limpet (Fig. 112) forms an example of a Mollusk of a different order, in which the gills extend like a fringe round the lower edge of the body, and

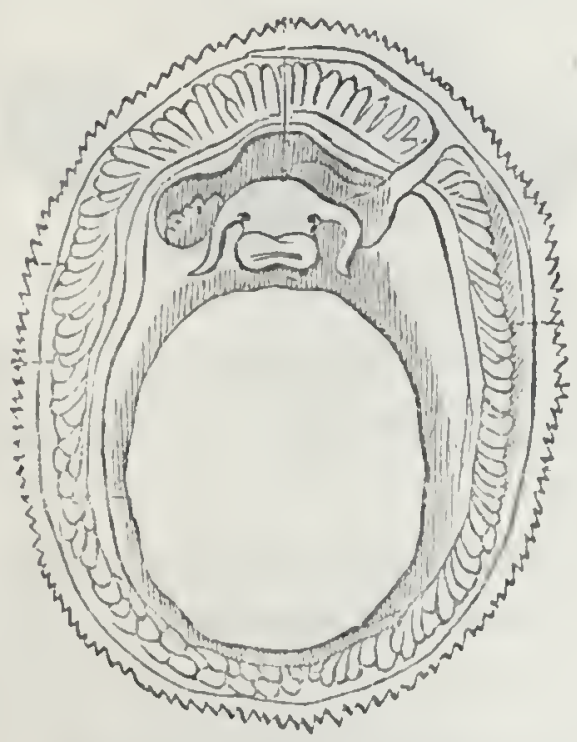

Fig. 112.-ANimal or LiMpet.

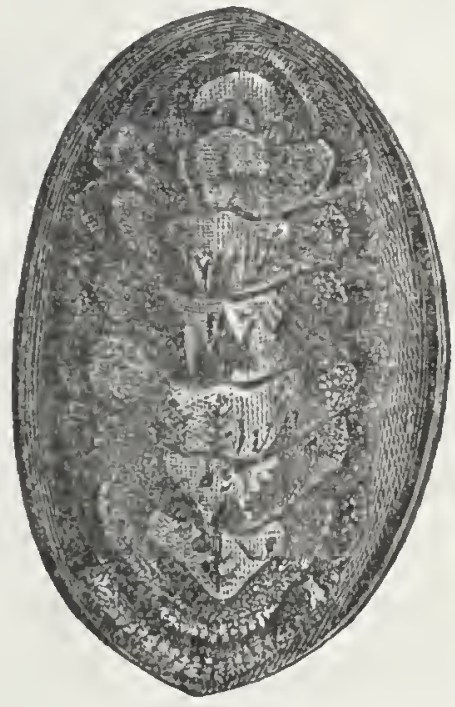

Fig. 113.-Chiton.

between the body and the foot. Those who see the Limpet only when left uncovered by the tide have no idea of the case with which it can march about when 
the returning waters once more surround its dwelling. Its little excursions are not, however, merely for amusement; they are undertaken for the important object of procuring focd. This consists of sea-weeds of different kinds, which it rasps down with its tongue-a ribbon-shaped instrument longer than its entire body.

The shell of the Limpet consists of one piece; but in the Chiton (Fig. 113), an allied genus found near low water-mark, and under stones, the shell is composed of a number of distinct plates. These are so arranged that the edges overlap like the slates of a house, and yet they are joined together by a substance which bends so easily that the shell can, at the pleasure of the animal, be rolled into a ball.

Fig. 114 represents a different species. Such shells occur in groups, and are always found attached to

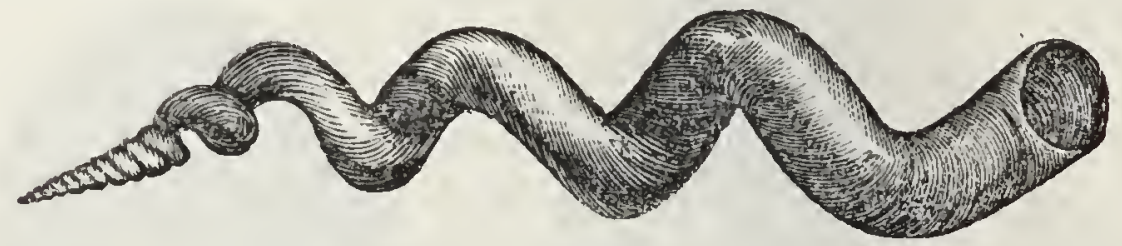

Fig. 114. - VERMETUS.

other bodies. They bear some resemblance to the tubes of the Serpulce (Fig. 24), though the contained animals are widely different.

The Dog-whelk, a shell that is common on our shores, furnishes a purplish dye, which makes an excellent marking ink. It is not, however; to lue supposed that this fluid is identical with that dye for which Tyre was so celebrated when its "merchants were princes, and its traffickers the honourable of the eartl," and which was reserved for the brilliant hangings of temples, or the costly robes of priests and kings. By what shell 
this dye was produced, and how it was extracted, have been questions respecting which inuch difference of opinion has prevailed. Mr. Wilde, when visiting the ruins of Tyre in 1838, found on the shore a number of round holes cut in the solid sindstone rock. Within them, and on the adjacent beach, were masses consisting of large quantities of broken shells. He inferred that the shells had been placed in those holes or mortars to be pounded in the manner mentioned by Pliny, for the purpose of procuring the fluid which the animal contained. This opinion was confilmed by his find-

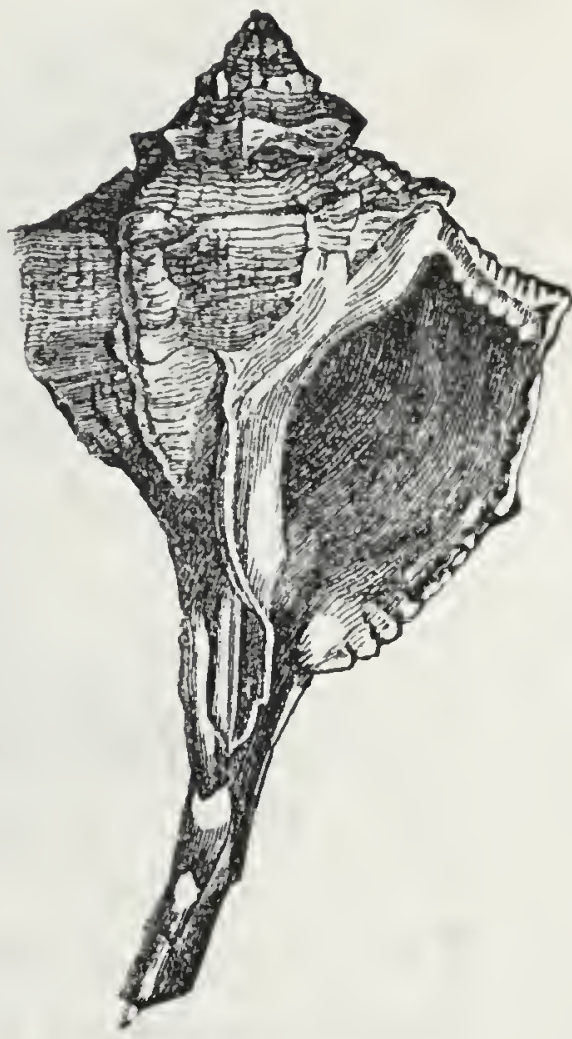

Fig. 115.-Murex. ing that the broken shells belonged to a species of Ifurex, one of those from which the Tyrian dye is known to have been obtained; and also from the same species being still found, in a living state, on the adjoining beach. The genus contains shells of great beauty (Fig. 115), some of which are furnished with long and delicate spines.

Although most Gasteropods are locomotive, yet they have merely the power of sliding slowly along by means of the foot which we have mentioned. But in one curious group of these animals the foot, instead of being broad and muscular, is quite altered in struc- 
ture and appearance, so as to fit the animal for swimming rapidly along the surface of the' sea (Fig. 116).

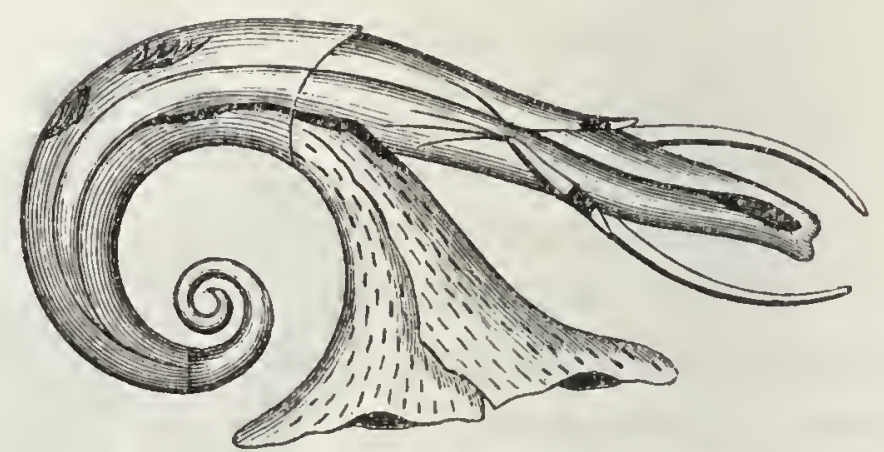

Fig. 116.-HETeroron.

\section{Class VII.CUTTLE-FISHES.}

\section{CEPHALOPODA.}

IF we look at a Cuttle-fish (Fig. 117), we notice that the head is surrounded by a number of legs or arms:

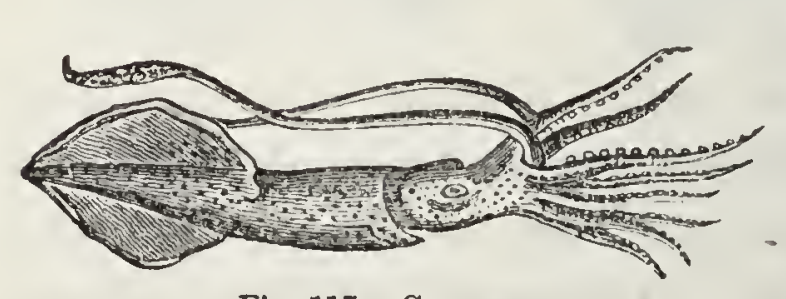

Fig. 117.-CaLAMart.

this peculiarity is implied in the scientific term by which the class is named.

In many important points of structure, this class is superior to any of those yet mentioned.

The Pearly Nautilus (Fig. 118) belongs to this class. Though its shell is common in museums, the capture of the living animal is of rare occurrence. We know, however, that it occupies only the outer chamber of its shell, and that it can rise to the surface or descend at 
pleasure. Similar in structure and in powers were the Ammonites (Figs. 119, 120), which, at former periods

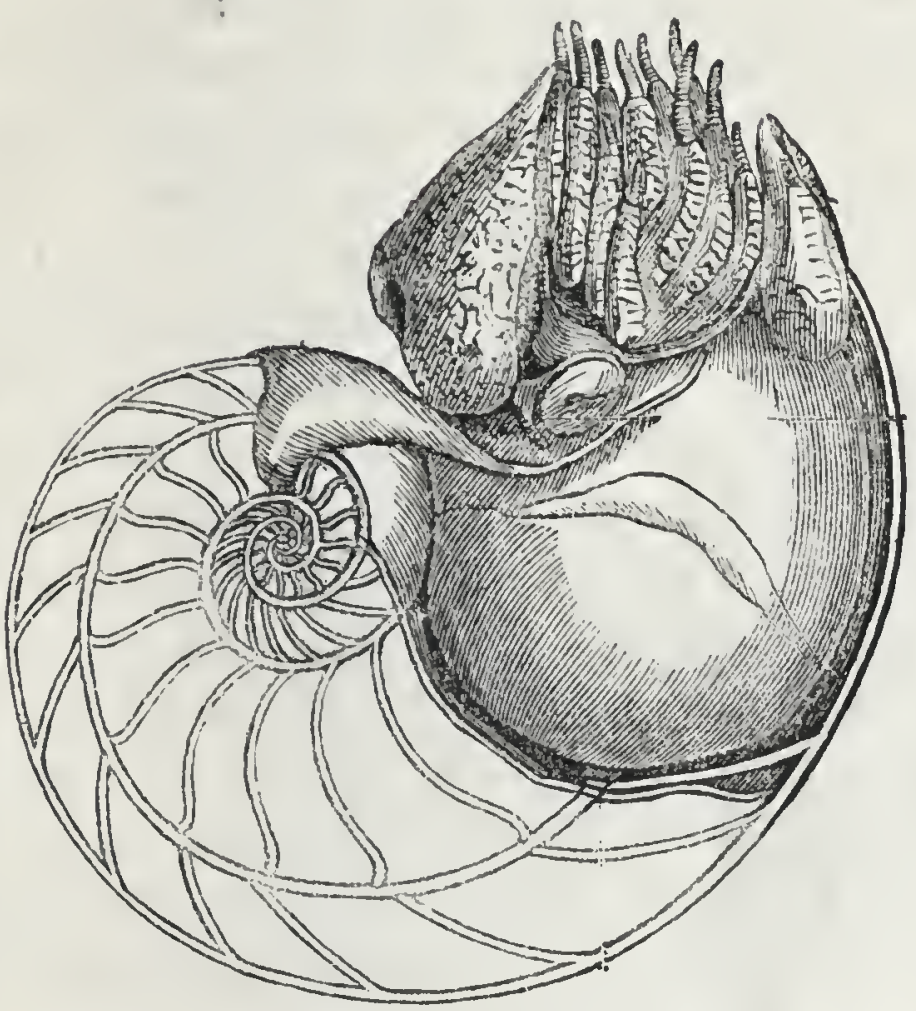

Fig. 118.-Pearly Nautilus, with Shell laid open.

of the earth's history, must have been living in its seas, though now known only as fossil.

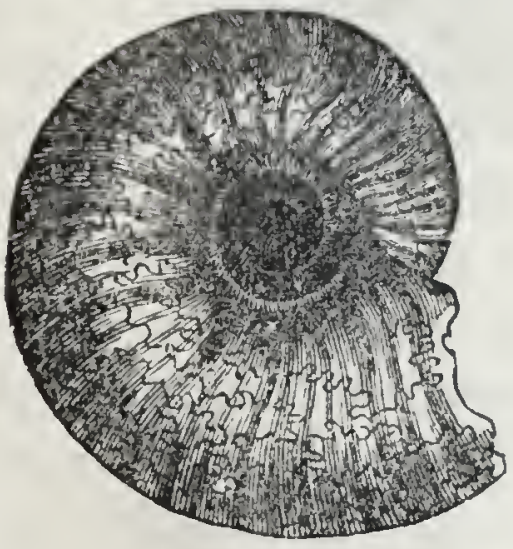

Fig. 119.

Amonitis.

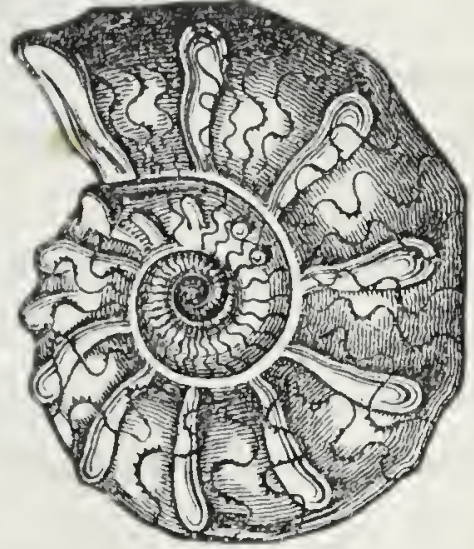

Fig. 120.

Other Cuttle-fishes abound in all seas, and are 
arranged in two divisions, according as they have eight or ten arms. To the latter group belongs the Loligo or Calamary (Fig. 117), the common Sepia or Cuttlefish, and the Loligopsis (Fig. 121), so remarkable for the

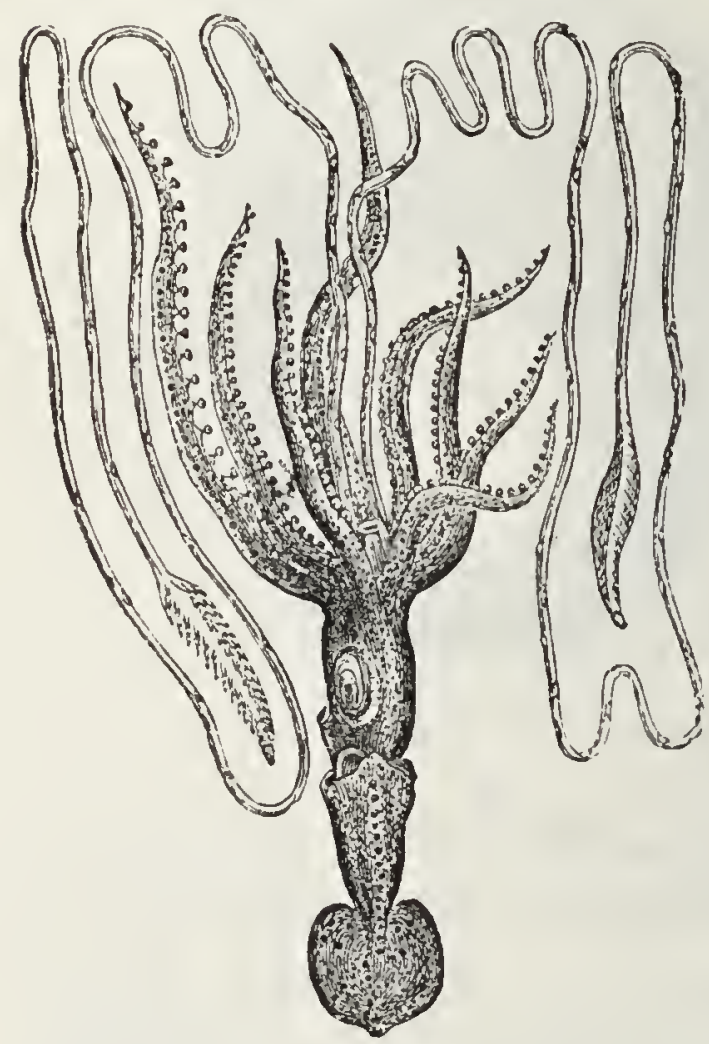

Fig. 121.-LoLIGOPSIS. greatlength of one pair of its arms. All possess an internal shell, differing in form and structure in different species; all are finnished with a powerful horny beak, for tearing up their prey, and with an ink-bag, from which, at pleasure, they can emit a fluid which darkens the water, and favours their escape from their enemies.

Of the eight-armed division, the most interesting species is the Argonaut or Paper Nautilus, regarded as giving to man the first example of the art of navigation. Such being the universal belief, poets have not failed to celebrate its nautical powers. Thus Montgomery has given us a picture so exquisitely finished that even the naturalist can scarcely bring himself to wish that it were different,-

"Light as a flake of foam upon the wind, Keel upward, from the deep emerged a shell, Shaped like the moon ere half her horn is fill'd; 
Fraught with young life, it righted as it rose,

And moved at will along the yielding water.

The native pilot of this little bark

Put out a tier of oars on either side,

Spread to the wafting breeze a twofold sail, And mounted up and glided down the billow In happy freedom, pleased to feel the air, And wander in the luxury of light."-Pelican Island.

It is now ascertained that the Nautilus never moves in the manner here described. The account, though so universally believed, is altogether fabulous. It swims backwards, by sending out a jet of water through what is called the "funnel." It creeps along the bottom, carrying its shell upon its back, as a snail would do (Fig. 122). It has the power, like many other Mollusks, of rising to the surface; but there the arms are never employed as oars; and those which have the broad expanded dises are never used as sails. The true use of those discs is to secrete the shelly matter

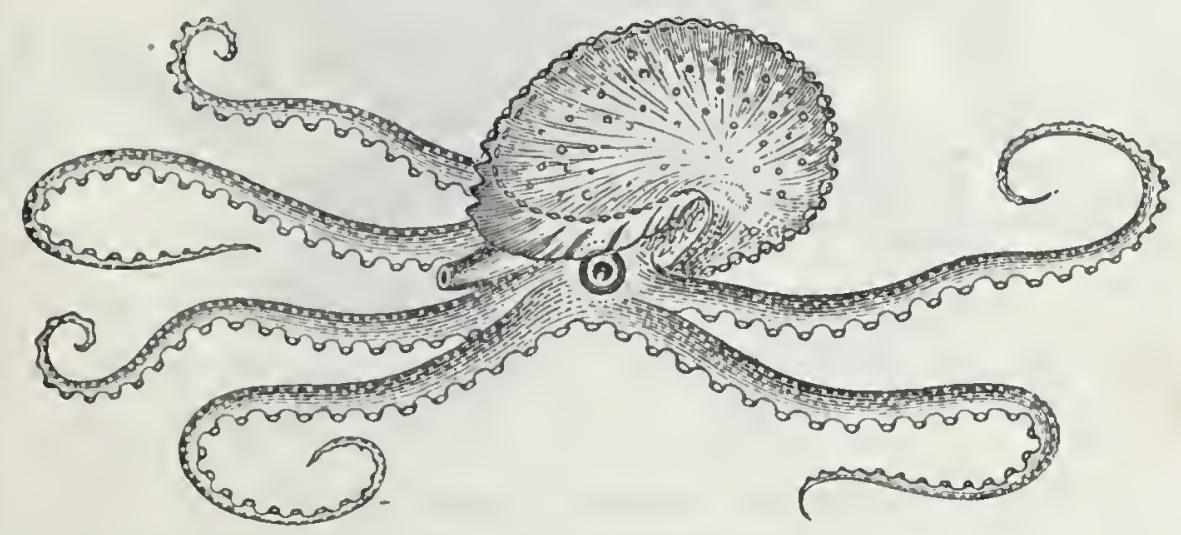

Fig. 122.-ArgoNaUt.

needful for the repair or enlargement of the shell, over which, in our figure, they are represented as stretched (Fig. 122). When the animal floats upon the surface the shell is beneath the body.

The female Argonaut, floating in her pearly boat, is 
both owner and commander. To her alone the beautiful and graceful shell belongs. The male is smaller in size, and, like other Cuttle-fishes, is houseless.

The Octopus or common Poulpe (Fig. 123) is a species of eight-armed Cuttle-fish, whose strange figure and staring eyes cannot fail to excite attention, especially when its twisting arms are employed in the act of walking. These arnis have, however, another office, which is thus described by Professor Jones:- "They are used, if required, as agents in seizing prey, and of so terrible a character, that, armed with these formid-

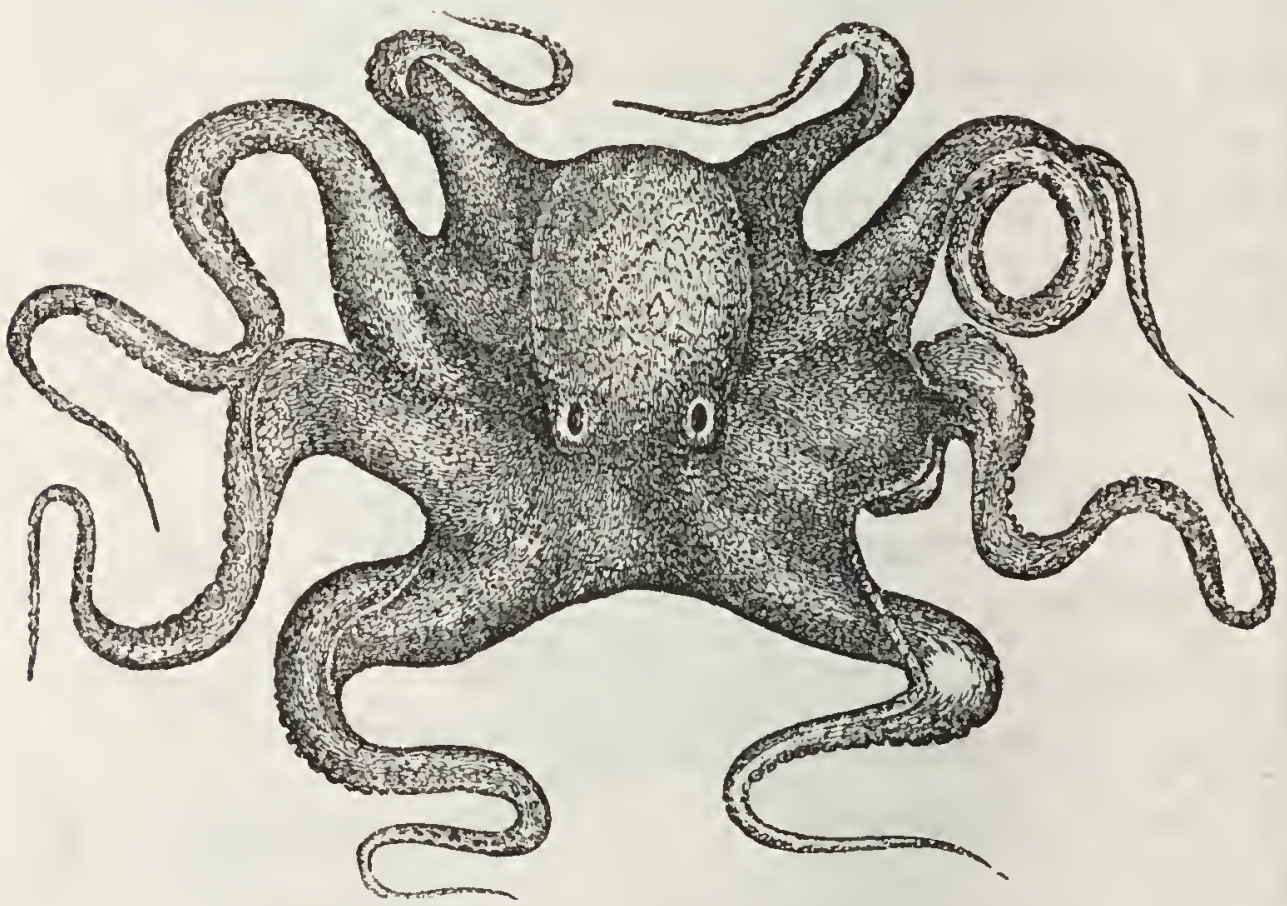

Fig. 123.-Octopus, or Poulpe.

able organs, the Poulpe becomes one of the most destructive inhabitants of the sea; for neither superior strength, nor activity, nor even defensive armour, is sufficient to save its victims from the ruthless ferocity of such a foe. A hundred and twenty pairs of suckers, more perfect and efficacious than the cupping- 
glasses of human eontrivanee, erowd the lower surface of every one of the eight flexible arms. If the Poulpe but touch its prey, it is enough; onee a few of these tenaeious suekers get firm hold, the swiftness of the fish is unavailing, as it is soon trammelled on all sides by the firmly holding tentaeula, and dragged to the mouth of its destroyer. The shell of the Lobster or Crab is a vain protection; for the hard and erooked beak of the Cuttle-fish easily breaks to pieees the frail armour."

An instanee of its powers, both of attaek and escape, fell under the observation of Mr. Broderip, of London. He attempted, "with a hand net, to cateh an Oetopus that was floating within sight, with its long and flexible arms entwined round a fish, whieh it was tearing to pieces with its sharp hawk's bill. The Cuttle-fish allowed the net to approaeh within a short distanee of it before it relinquished its prey, when, in an instart, it relaxed its thousand suekers, exploded its inky ammunition, and rapidly retreated under eover of the eloud whieh it had oeeasioned, by rapid and vigorous strokes of its eireular web."

Besides the eapability of thus eseaping when pursued, it also possesses, in eommon with others of its elass, a proteetion against being discovered, which, along with the other, surpasses the eloak of darkness in the fairy tale. It ean change its colour to that of the objeets whieh are near at hand; so that, like the Ptarmigan in the snow, it is almost unseen. In faet, the power whieh Cuttle-fishes possess of changing their eolour, and making it resemble that of the surface on which they rest, appear's quite as remarkable as that which has long been eelebrated in the Chameleon. 
Stories are told of gigantic Cuttle-fish throwing their arms over luckless vessels, the thickness of each arm being equal to that of the mizzen-mast. But it is a part of the business of science to dispel these stories, and patiently and laboriously to seek out the truth, hailing with joy each new light which may shine on the subject of inquiry. In the College of Surgeons, London, are preserved portions of the largest specimen of a Cuttle-fish which any of our museums contain. The carcass was found during Captain Cook's first voyage, floating on the sea, surrounded by birds, which were feeding on its remains. Comparing the size of this animal, from the parts existing, with that of the smaller perfect animals, its body must lave been at least four feet long, which added to the tentacula, would make it seven feet in length. We have, in these countries, no positive evidence of the existence of any Cuttle-fish of larger dimensions; but naturalists are not disposed to deny the possibility of their occurrence.

We have now finished our brief survey of the Invertebrate Animals. We have seen in our progress many strange forms and modes of life-creatures widely different from each other, yet each "perfect after its kind;" and we have thus been prepared to enter, with greater advantage, on the study of the higher orders of animals, where we find an internal skeleton, and other evidences of their more elevated rank in the animal kingdom.

END OF PART I. 


\section{PART II.}

\section{VERTEBRATE ANIMALS.}

WE are now prepared to enter upon the examination of the more highly organized beings which constitute the fifth great division of the animal kingrlom. These have a more complex or less simple structure and a higher intelligence: some among them are distinguished by their great size and strength; and in this class, after passing many inferior grades, we reach to man himself.

The most obvious character by which the Vertebrate Animals are distinguished from the lower tribes is the possession of a skull and back-bone. They have red blood, a muscular heart, distinct senses, a mouth furnished with two jaws moving vertically, and limbs which never exceed four in number. They are distributed into five classes.

\section{Fishes.}

II. Asiphibia (Frogs, Newts, \&c).

- III. Reptiles (Tortoises, Lizards, and Serpents).

IV. Brrds.

V. Maminalia (Man, Bats, Whales, and Quadrupeds). Three of these, Fishes, Amphibia, and Reptiles, are, with few exceptions, cold-blooded; and the remaining two, Birds and Mammalia, are warm-blooded. 


\section{ClaSS I.-FISHES.}

PISCES.

"They that go down to the sea in ships, and occupy their business in great waters;

"These men see the works of the Lord, and his wonders in the deep" PSALMS.

Fishes are cold-blooded animals, formed for living as inhabitants of the water. The body is, in most instances, covered with scales; they have fins instead of feet; and their breathing is carried on by gills.

Fishes are found in lakes, rivers, and seas, and live at very different temperatures. Even the same species seems capable of bearing considerable extremes of heat and cold. The delicate-looking Gold-fish thrives and breeds to excess in water the temperature of which is so high as $80^{\circ}$, and has been frozen in a solid body of ice, and revived by the gradual application of warmth.

In some warm countries fishes are known to avoid the great drought of the warm season by burying themselves in the mud, at the bottom of the tanks or ponds in which they live: the surface may be changed into dust by the extreme heat, yet the buried fishes remain uninjured, until the return of the rainy season rouses them once more to active life.

The great variety of form observable among fishes may be illustrated by reference to some of our most common native species-the Eel, the Plaice, and the Hiaddock. Some can, to a certain extent, vary the form of their body at pleasure. Thus the Diadon, or 
Globe-fish (Fig. 124), by swallowing air can inflate itself like a balloon. The air passes into the first stomach, which occupies the lower surface of the body. This part, becoming the lightest, is that which remains uppermost, and the fish floats on the surface with its usual position reversed, and all its spines erect, presenting on every side a bristling front to all assialants.

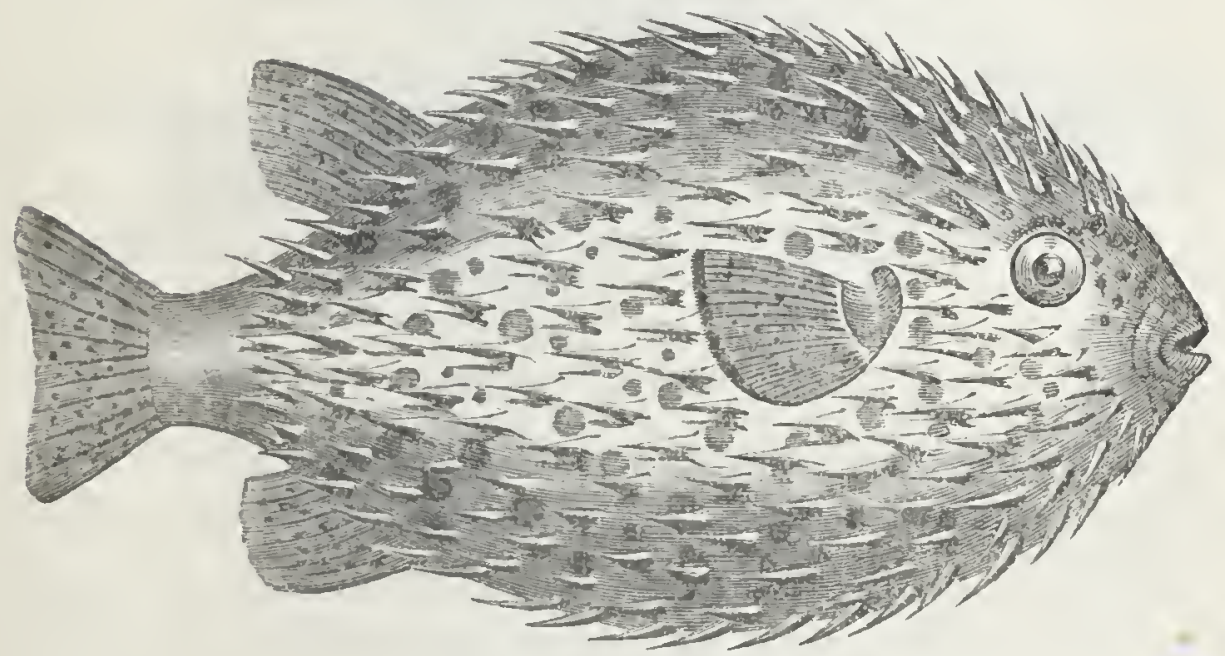

Fig. 124.-GLOBE-FISIr.

Many species are furnished with a beantiful apparatus, by mans of which it is supposed that they can make their bodies lighter or heavier than an equal bulk of water, and can thus rise or sink without effort. This is effected by means of a membranous bag, known as the "swim-bladder;" the same part which in the Cod-fish is termed the "sound."

The external organs of motion consist of the tail and fins, and the fins are named from the part of the body to which they are attached.

In the Flying-fish (Fig. 125), the pectoral fins, or those on the shoulders, are extremely large, and remind us of wings. But in reality the fins never act as 
wings; nor can these fish, with correctness, be said to $f y$. They have the power of springing out of the water with such force that Capt. Hall has seen them pass over a space of 200 yards; but they cannot alter the

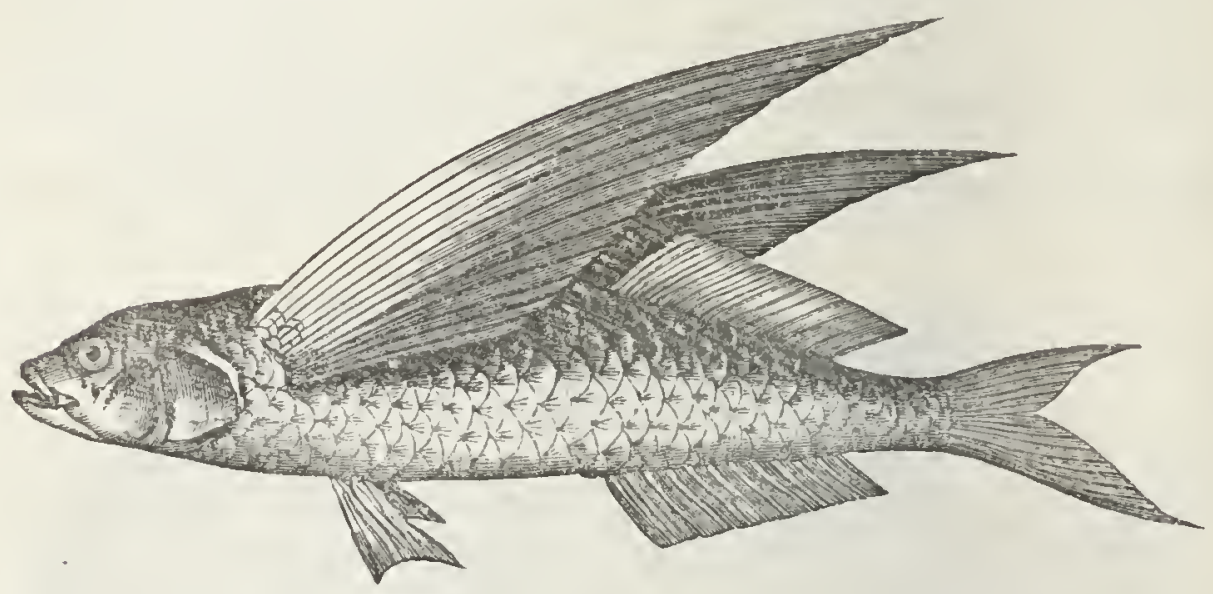

Fig. 125.-FLTING-FISH.

direction of their course, and the expanded fins, when in the air, serve only to make the descent more gradual.

There is great variety in the food of fishes. Some live on marine vegetables, others upon animals belonging to the invertebrate tribes, and upon the young and weaker individuals of their own class.

The young are in general produced from eggs laid by the female and fertilized by the male. The lobes containing the eggs or ova are those to which we are accustomed to give the name of "pea" or "roe," and the corresponding but softer lobes in the male fish are those which are equally well known as the "milt." The number of eggs or ova in some of our native fishes is so very astonishing that it would be regarded with doubt, except on the best testimony. So many as 280,000 have been taken from a Perch of only half a pound weight; and the Cod-fish is said to contain severul millions. Few of the young ever live to reach 
their full size,-they form the appointed food of their more powerful neighbours. We see, therefore, in the profusion in which they are produced, a wise provision for keeping up a supply sufficient to meet the neverending consumption.

Several instances can now be quoted of fishes constructing nests in which the eggs are placed, and round which the parents keep guard with the most watchful care. One of our most common native fishes, the little Stickle-back, not only builds a nest, but keeps guard over the safety of the young fry. When some thoughtless youngster escapes from the nursery, the parent fish has been seen to catch it in a way so strange, that I had better use the words of the naturalist by whom the occurence was witnessed.

"The fry were, at first, so minute and transparent that they could scarcely be discerned as they lay partially concealed amid the meshes of the nest. As I was closely watching their motions, one of the newly hatched fishlings, with intrepidity beyond its experience, ventured to pass the limits of its cradle: in an instant the watchful parent was there, and, with gaping month, seized the little wanderer, which immediately disappeared, the jaws having closed upon it. Seeing this, I at once gave up the fry for lost, deeming that here was an instance of instinct at fault, and that all the affectionate solicitude of the parent was to end in its devouring its offspring. In this I was mistaken; the old fish, quietly returning, dropped the straggler into its nest, lively and uninjured. During the whole of this diry none of the fry were permitted to ramble beyond the precincts of their fold; and when any 
attempted to do so-and many did attempt-they were invariably brought back in the mouth of the parent: none escaped its vigilant eye, and it was amusing to see with what a hurried, fluttering motion the little things dropped almost perpendicularly dow'n into the nest, so soon as they were released from the jaws of the parent." *

There are some fishes that are without jaws properly so called, but have circular mouths; and these they can, at will, employ as suckers. By so using them the Lampreys remove stones or pebbles from the hollow which they excavate to form their spawning bed.

Various are the weapons, offensive and defensive, with which fishes are furnished.

The Stickle-back (Fig. 126) at the lower surface of its body has a stiff, sharp spine, which can be erected

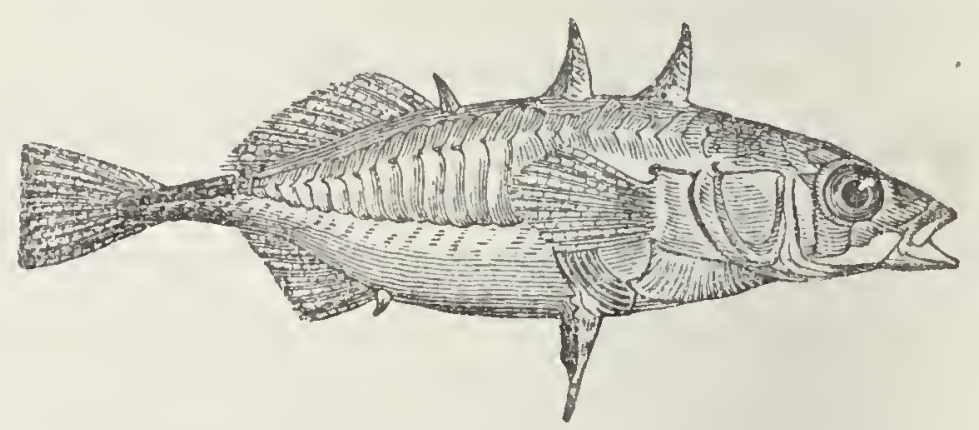

Fig. 126._STICKLE-BACK.

at pleasure so firmly, that the fish may be said, in military phrase, to "fix bayonets." The Stickle-back is an irritable little fellow, and with this bayonet of his has been seen to rip up the belly of an opponent, so that he sank to the bottom, and died of his wound.

* Albany Hancock, Annals Nat. Hist., 1852. 
In the Sword-fish (Fig. 127) the upper jaw forms the sword, which is often three or four feet long. The fish itself occasionally attains a length of twelve feet, and a weight of more than four hundred pounds. It is a commonly reeeived opinion that the Sword-fish has a great enmity to the Whale, and that whenever it drives its sword-like beak into the hull of a ship at sea, the vessel has been mistaken for that animal.

The foree with which this is done must be very considerable; for not only is the eopper sheathing of the vessel oeeasionally piereed, but even several inches of the solid timber. Instances are even recorded of vessels having suddenly sprung a leak, and being with diffieulty got into port, from injury thus eaused by the Sword-fish.

A still more eurious mode of defenee is that of giving a severe electrie

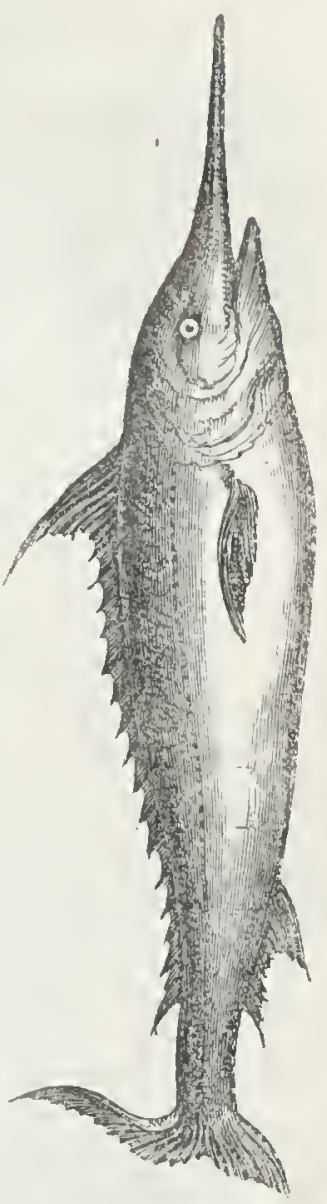

Fig. 127.-SwORDFISII. shock. The Torpedo, or Eleetric Ray of our own shores (Fig. 12S), is one example of this; and another is furnished by the Eleetrie Eel of the South American rivers, whose shoek is so powerful as to stun and even destroy horses.

There are several other species that possess this remarkable power. Its existence was known to the physieians of Greece and Rome, and employed by them as a remedy for certain nervous affections. It is stil 
used for giving shocks by the Sonth American Indians, the Abyssinians, and other tribes living along the banks of rivers where electric fishes are found.

There are some fishes which, owing to a peculiarity in

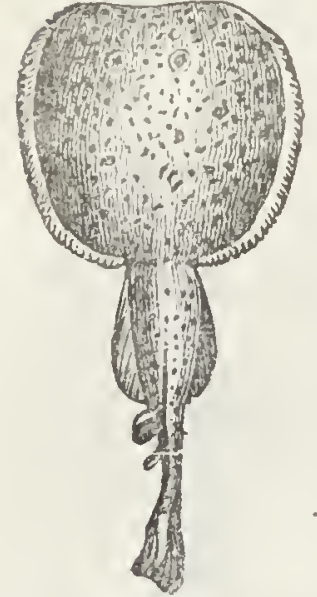

Fig. 128.-TorPEDO. structure, are enabled to retain a supply of moisture, and thus keep the gills damp. Such fishes, strange as it may seem, are known, in the dry season, to leave the pools they had lived in, and shape their course towards the nearest pool of water. Sir J. E.' Tennent, in his IIistory of Ceylon, gives examples of this curious fact in Guiana, Siam, and Ceylon. In the last named country the species so distinguished is a small perch, about six inches in length, "This little creature issues boldly from its native pools, and addresses itself to its toilsome march generally at night or in the early morning, whilst the grass is still damp with the dew; but in its distress it is sometimes compelled to travel by day, and Mr. E. L. Layard on one occasion encountered a number of them travelling along a hot and dusty gravel road under the mid-day sun."

The skeleton of some fishes is composed of cartilage or gristle, that of others is of bone. Fishes are therefore arranged in two great divisions, according to the nature of the skeleton. Those which have the skeleton of bone form much the more numerous group: this is divided into two other groups, in one of which the fins upon the back consist wholly or in part of stiff rays united by a membrane; and in the other the fins have soft flexible rays, dividing into numerous branches. 
The groups thus formed are again subdivided, according to the presence or absence of certain fins-the difference in their relative positions-the variety in the structure of the gills and gill-covers, and other less important details. In this way, according to Cuvier's classification, all fishes are arranged in nine Orders, three of them being devoted to the "cartilaginous," or those which have the skeleton of cartilage or gristle, and six to the "osseous," or those in which the skeleton is formed of bone.

\section{CARTILAGINOUS FISHES.}

\section{ORDER I.-LAMPREYS.}

The first order of these fishes has its peculiarities well shown in the River Lamprey (Fig. 129). A row of

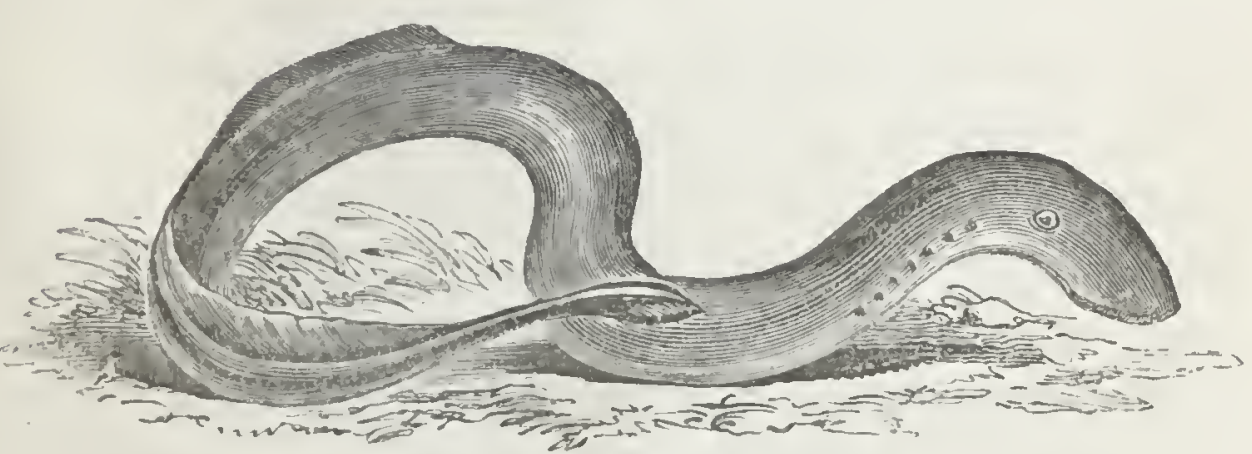

Fig. 129.-River Layrrex.

circular openings along each side of the neck leads to gills of a similar form; and the circular mouth, by means of which the fish can adhere to stones, has procured for the family a scientific name which signifies "stone-sucker's." 


\section{ORDER II.-SHARKS AND RAYS.}

These fishes, though differing much in external form, belong to the same group-one which is readily known by the structure of the gills, the long-shaped gill-apertures or openings, and the peculiar form of the mouth.

The figure (Fig. 130) represents the Small-spotted Dog-fish, one of the family of the Sharks, and an

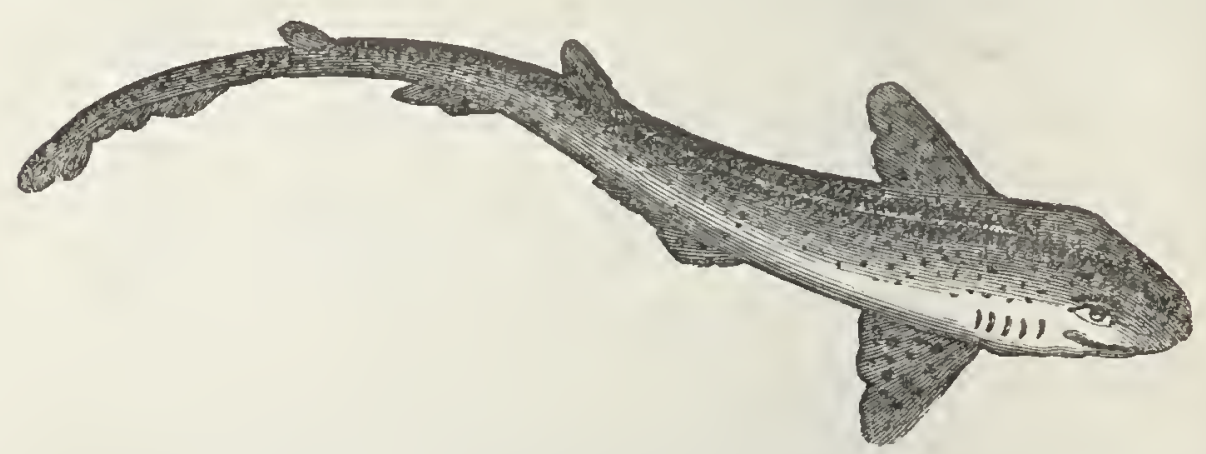

Fig. 130.-SMaLL-SPOTtEd DOG-FISH.

object of great dislike to fishermen, because of the injury which they believe it causes to their fishing.

The eggs of both Sharks and Rays are few in number, and are not deposited on the sand or gravel, but each egg is enclosed, for greater safety, in a horny case, attached by long tendrils to the larger seaweeds; and among the Sharks of the largest size, some bring forth their young alive. The empty eggcases are frequently found on the sea-shore, and are well known by the name of "sea-purses," "mernaids" purses," and other local terms. The longer and narrower-shaped belong to the Sharks and Dog-fishes; the broader and shorter ones to the Skates or Rays. The figure (Fig. 1.31) represents the case laid open, 
and the young Dog-fish attached to the "yoke," or" bag of nutriment. Water is admitted by means of a.s. slit at each end of the purse, and through one of these the young fish effects its escape.

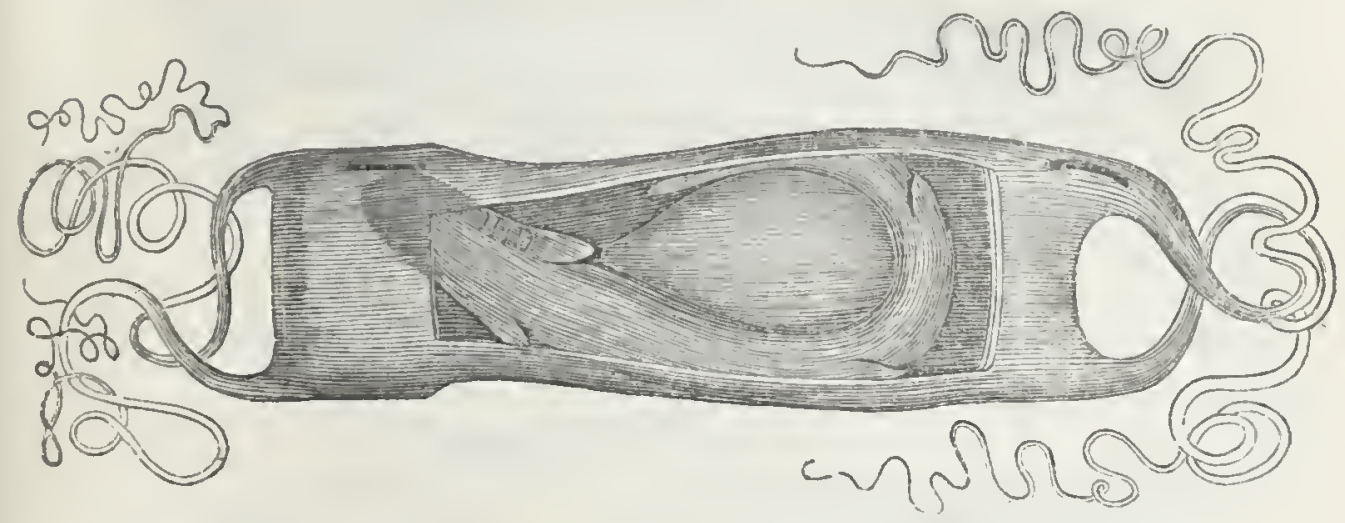

Fig. 131.-EgG-BAG, WITH roudg Shark.

Some of the Sharks attain a great size. The Basking Shark, a species found off these coasts, has been known to measure thirty-six feet in length, and is

- one of the largest of the true fishes.

\section{ORDER III.-STURGEONS.}

Is the third order of cartilaginous fishes there is an approach, in some points, to those belonging to the other great group. The gills are comb-shaped and there is one large gill-opening. This group is represented by the Sturgeon (Fig. 132), a fish which attains so large a size that one taken in the Esk weighed 464 lbs. The form of the tail in the Dogfish (Fig. 130) and the Sturgeon (Fig. 132) is very 
unlike that of the Pollan (Fig. 138), or the Pilotfish (Fig. 141), and forms one of the best outward

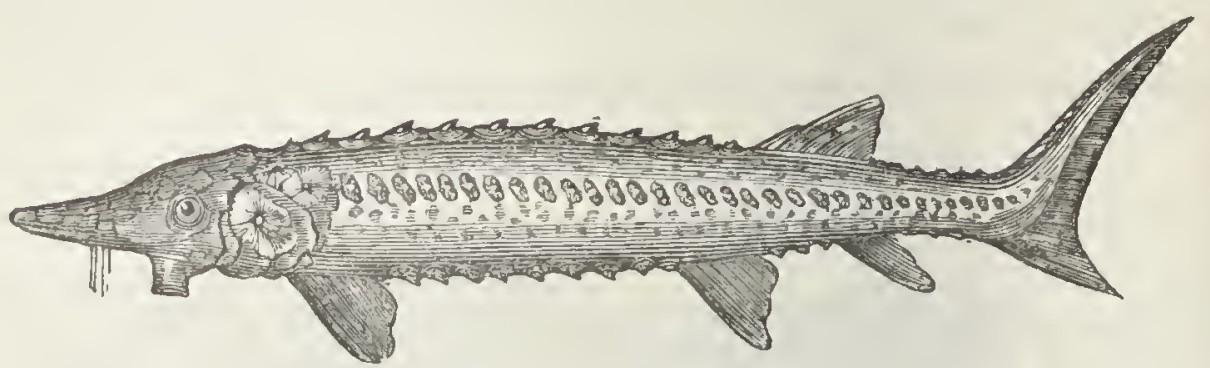

Fig. 132.-STUrgeon.

marks by which the cartilaginous fishes may be distinguished from the osseous.

\section{OSSEOUS FISHES.}

WITH THE RAYS OF THE FINS FLEXIBLE.

\section{OrDer I.-GLOBE FISHES.}

The first order of fishes, with the skeleton of bone, has points of structure which connect it with the previous division, which has the skeleton of cartilage. To it belongs the Globe-fish already mentioned (page 123, Fig. 124).

\section{Order II.-PIPE FISHES.}

The second order is one in which the gills are arranged like little tufts, as in the Pipe-fishes, which are very common on certain parts of the coast. Their 
skin is not covered with scales, but formed of plates nicely joined together, like that kind of pavement called "tesselated." The one shown in the annexed figure (Fig. 133) is the largest of our native species, and is furnished with a sort of sac in which the

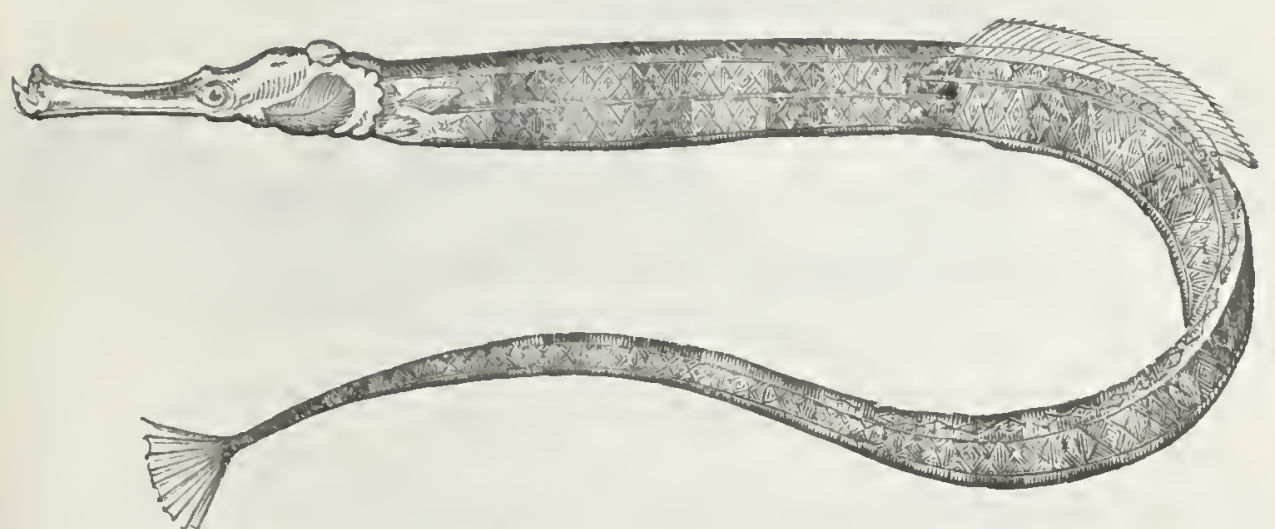

Fig. 133.-PIPE-FISE.

young are for a time carried about. It reminds us, in some respects, of the well-known pouch of the female Kangaroo; but, strange to say, among the Pipe-fishes, the marsupial pouch belongs not to the female but to the male. In the month of July the young are hatched and quit the pouch, but they follow their father, and return for shelter into their nursery when dinger threatens.

\section{Order III.-EELS.}

The fishes of the next order are distinguished by the total absence of what are called the ventral fins, or those on the lower surface of the body, and bear a scientific name which has reference to this peculi- 
arity. The species common on our shores exhibit a great contrast to each other in point of size. The little Sand-eel is usually from five to seven inches in length; while the Conger Eel (Fig. 134) is some-

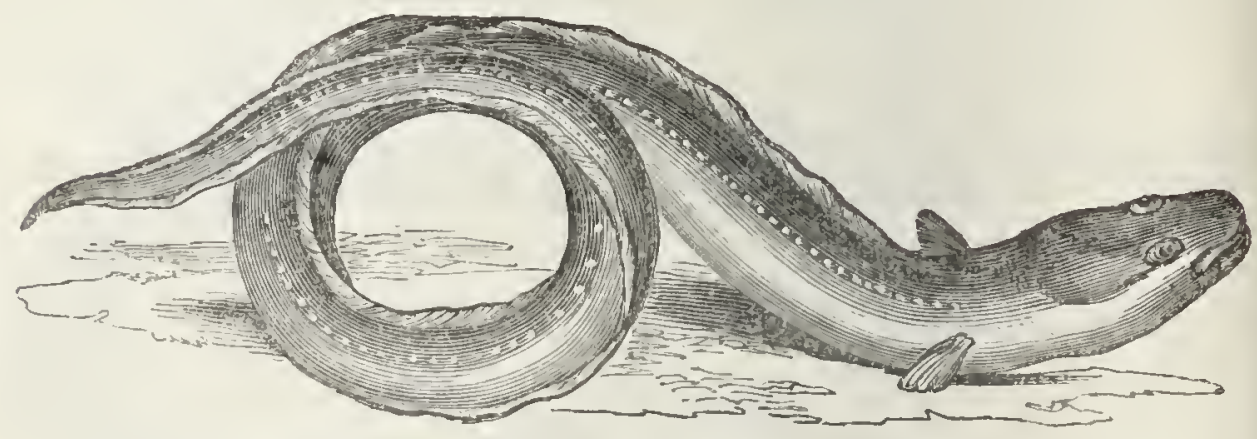

Fig. 134.-CoNger EeI.

times more than ten feet long, and 100, or even 130 lbs. in weight. There is a notion yet current that common Eels going into the sea remain there, and grow into Congers: an idea as unfounded as that of the child, who supposes that Ducks will grow into Geese.

\section{Order IV.-TURBOT, COD, \&c.}

The annexed figure represents the Remora (Fig. 135), a fish remarkable for an adhesive or sucking disc,

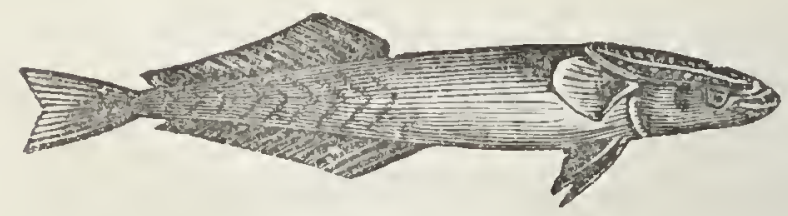

Fig. 135.-ReMrORA. which covers the upper part of the head, and enables it to adhere to the body of another fish, or to the bottom of a vessel. The species is interesting on this account, the more so because, according 
to old fables, it was said to have the power of stopping a vessel, even in lier most rapid course.

The sucking disc of the Lump-sucker, instead of being on the head, is at the lower surface of the body, and is formed in fact by the ventral fins, which, joining together, make a concave or saucer-shaped disc, by means of which it can adhere to stones or other bodies. This fish attracts our attention by his uncouth shape, red eyes, and the bright tints of blue, purple, and orange which are seen upon his body.

Among the fishes belonging to the present order are some which are well known and highly prized for the supply of food which they afford to man. Such as the Plaice (Fig. 136), the Turbot, and other well-known flat-fish. Few are aware of their importance re-

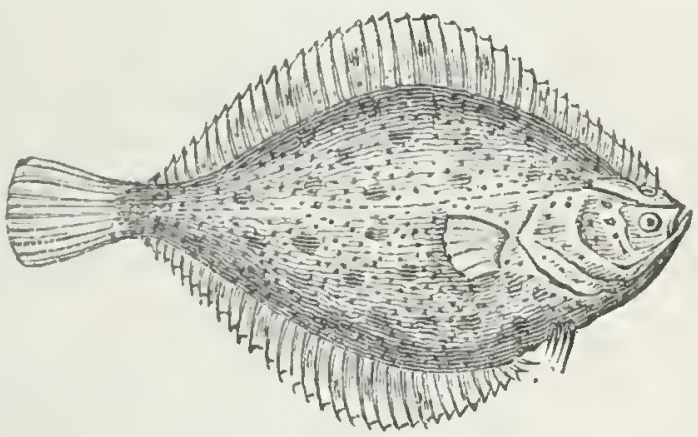

Fig. 136.-PLAICE. garded merely in the light of a marketable commodity. It is stated that for the Turbot brought to the London

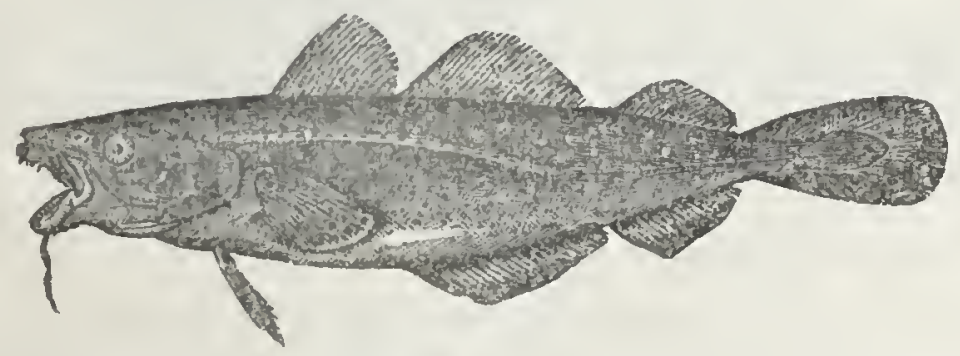

Fig. 137.-CoD.

market, the Dutch are paid so large a sum as $£ 80,000$ a-year.

To another family belong the Cod (Fig. 137), the 
Haddock, the Whiting, the Hake, the Ling, and others, which give employment on the British coasts to many thousands of hardy boatrnen and sailors. The great importance and value of the Newfoundland Cod Fishery is well known. Man annually derives from it an immense supply of food; and even the oil procured from the liver of the fish is of commercial and medicinal importance.

Let the reader contrast the position of the ventral fins in the Cod (Fig. 137) and the Pollan (Fig. 138), and he will understand the distinction between the fishes of this order and the next.

\section{Order V.-HERring, SALMON, \&c.}

"Forthwith the sounds and seas, each creek and bay,

With fry innumerable swarm, and shoals

Of fish that with their fins, and shining scales,

Glide under the green wave, in sculls that oft

Bank the mid sea."-Milton.

The description lere given by the poet, is to some extent realized by the multitudes in which the Pilchard-a fish belonging to the same family as the Herring-sometimes appears.

Ranking still higher as an object of national importance is the Herring itself, which gives occupation to thousands around the Britisl coasts, and supplies to hundreds of thousinds a cheap and favourite article of diet. 
The approach of the Herring has been described as that of a mighty army, which, coming from the arctic circle, divides at the Shetland Isles into two great bodies, one of which fills the creeks and bays of the east coast of Britain, while a part of the other, which passes into the Irish Sea, rejoices and feeds the inhabitants of the coast that border on it.

This account is altogether incorrect. The Herring does not abound in the arctic seas; and the division of the mighty army into brigades is purely imaginary. The Herring does perform a migration, but of a limited range. It comes to the shores for the purpose of spawning; and this being accomplished, it returns to the deeper water, where it habitually dwells. It is not a visitant from a distant region, but is like the Pilchard, a constant dweller in our own seas.

The Pollan (Fig. 138) is a fish which is not un-

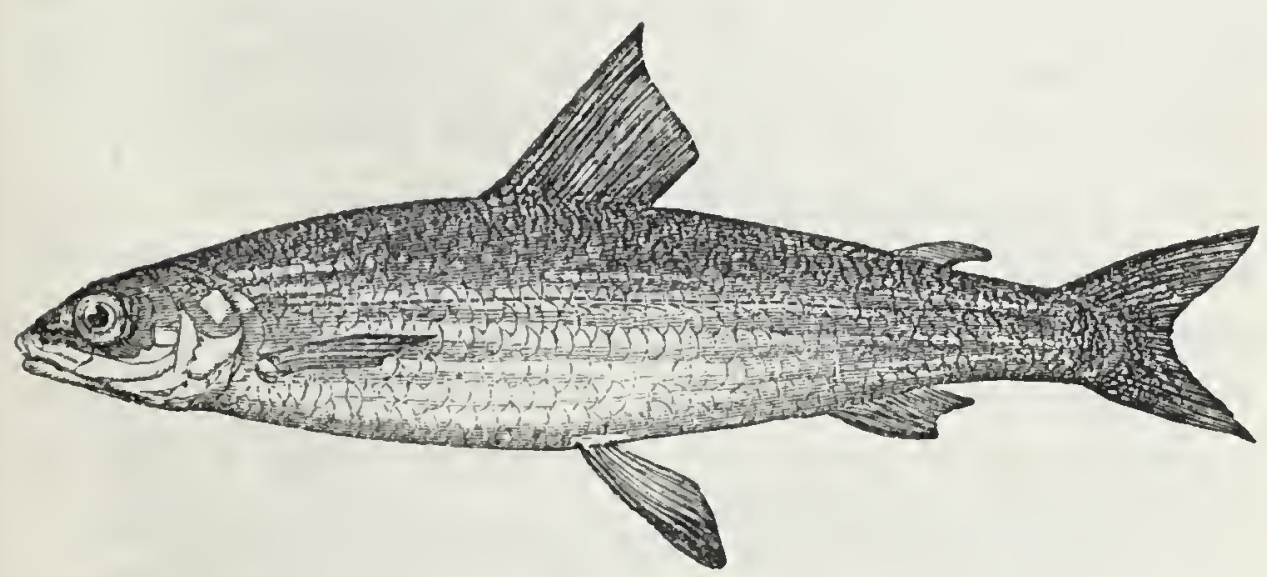

Fig. 13S.-PoLLdN.

frequently called the "fresh-water Herring." It is an Irish species, found in Lough Derg, Lough Erne, and Lough Neagh; and approaches the coasts in 
large shoals, not only during spring and summer, but when the autumn is far advanced.

Passing by the different species of lake and river Trout, we come to the most important member of the present family - the Salmon.

During the floods of winter and early spring, this fish descends the river to the sea, lean and ill-conditioned, and returns in a few months plump, wellconditioned, and greatly increased in size, from the abundance of food derived from small crustacea, fishes, and other marine animals and their eggs. It is on their return from the sea, for the purpose of spawning, that the Salmon are taken. This occurs during the summer and autumn months, the precise time being different in different rivers.

Impelled onwards by the instinct which prompts this migration, the Salmon endeavours to surmount all obstacles that lie in its course, and flings itself over ledges of rock ten feet or more in height above the surface of the water. It is said that at the falls of Kilmorac, in Inverness-shire, the Frasers of Lovat, lords of the manor, used occasionally, in a very singular manner, to bring this power under the notice of their guests. On a flat rock at the south side of the fall, and close to the edge of the water, a kettle was kept boiling, and the company waited until a Salmon fell into the kettle and was cooked in their presence.

Another family is that of the Pike, a strong, fierce, active, and voracious fish, of whose audacity many stories are told. Gesner relates that a Pike in the Rhone seized on the lips of a Mule that was brought to water, and that the beast drew the fish out before 
it could disengage itself. "At Lord Gower's canal, at Trentham, a Pike seized the head of a Swan as she was feeding under water, and gorged so much of it as killed them both; the servants, perceiving the Swan with its head under water for a longer time than usual, took the boat, and found both Swan and Pike dead."

\section{Order VI.-SPINY-FINNED FISHES.}

TuE remaining fishes have the dorsal or back fins supported in part by rays, which are spinous and undivided. In all of them the gills are arches, presenting the comb-like structure so well known in our most common and valuable fishes.

Of the habits of the Riband-shaped fishes, which form a group in the present order, little is known;

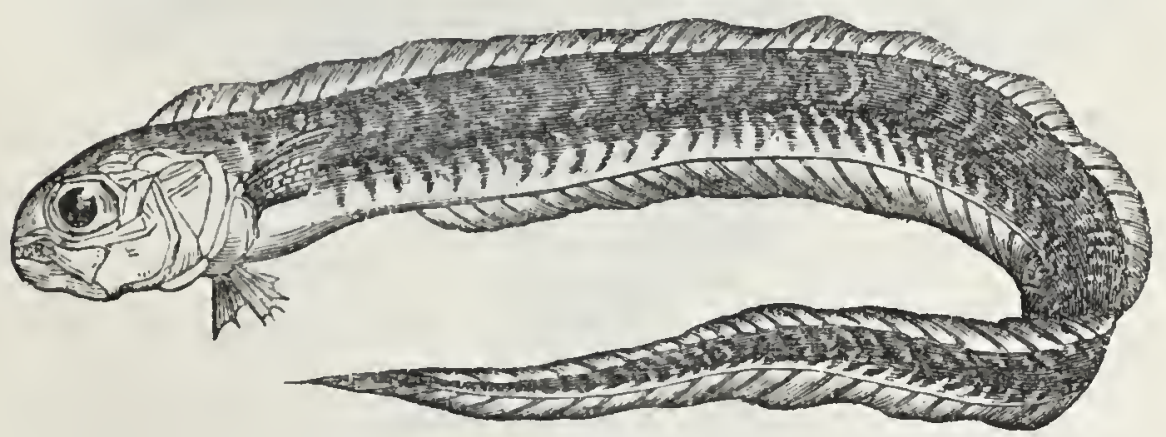

Hig. 139.-RED BAND-FISI.

but one fact may be mentioned to show how appropriate is their name. A specimen of the Red Bandfish (Fig. 139), in 1837, when the penny postage was 
unknown, was sent to Mr. W. Thompson, of Belfast, through the post-office, although nineteen and a half inches long; it was fulded up like a riband, and passed in a franked letter of the ordinary size and legal weight-under an ounce.

The next family contains the Sword-fish (Fig. 127), and others which, either from their habits or traditions with which they are associated, are regarded with more than usual interest. One of them is the John Dory (Fig. 140), which, as well as the Haddock, lays claim to

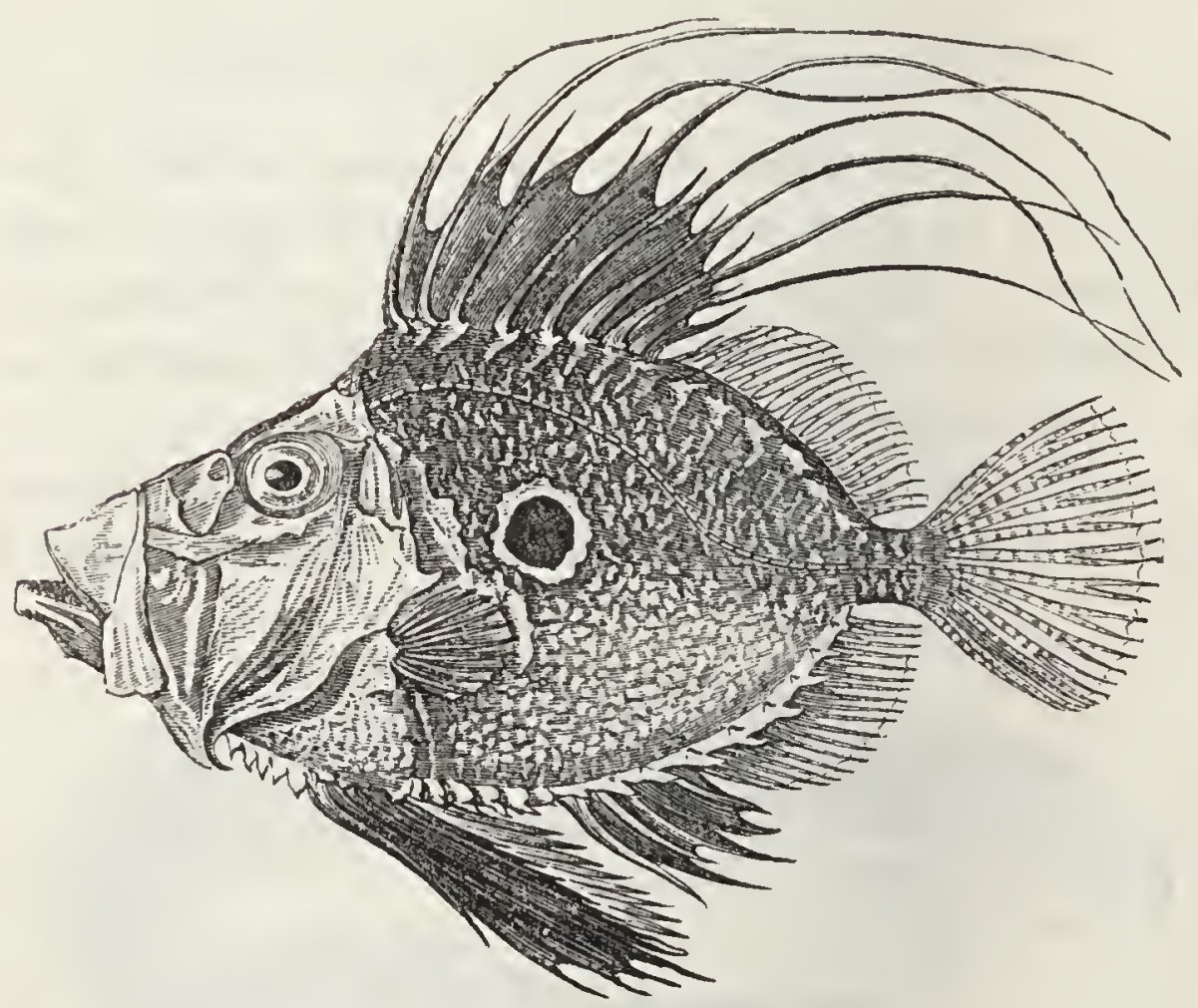

Fig. 140.-JoHN DORY.

the honour of bearing the marks of St. Peter's fingers - each being supposed to have been the fish out of whose mouth the Apostle took the tribute money, leaving on its sides, in proof of the identity, the 
marks of his finger and thumb. Another is the Pilot-fish (Fig. 141), celebrated for its attendance on the large Sharks, and supposed by the ancients

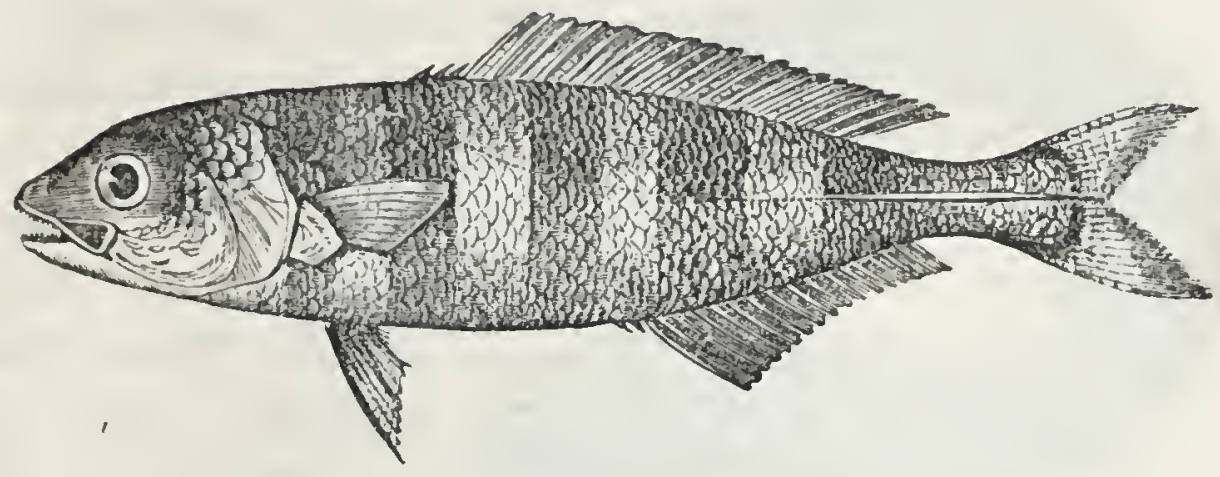

Fig. 141.-PILOT-PISH.

to have pointed out to navigators their desired course, and borne them company during their voyage. A third is the Tunny (Fig. 142), a fish of large size, though here represented by a very small figure. One killed at Inverary weighed 460 lbs., and measured seven feet ten inches in length. 'The

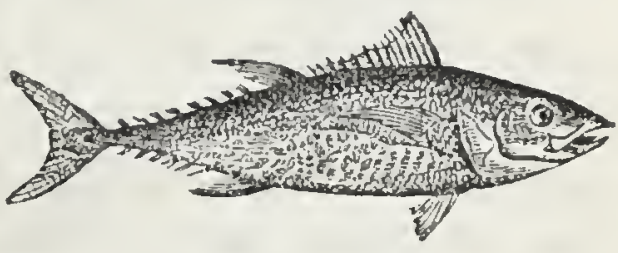

Fig. 142.-TUNNx. 'Tunny visits the shores of the Mediterranean in great shoals, and gives origin to an extensive and valuable branch of commerce. It is spoken of by the fishermen there as warm-blooded, and observations show that in this they are quite correct. It swims near the surface of the water, in this respect resembling the Bonito, a fish with blood as warm as that of a man!

In our progress through the different grades of animals we occasionally meet with individuals which seem to combine the characteristics of two distinct: 
groups, and render it an interesting problem to determine in which they should be placed. Such is the Lepidosiren (Fig. 143), an animal which inhabits a part of

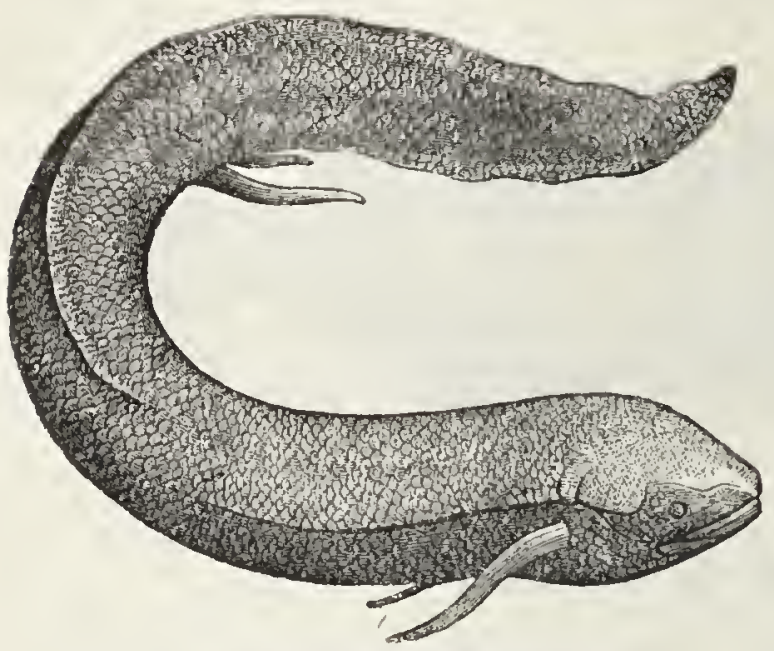

Fig. 143.-LePidosiren. the river Gambia, which overflows extensive tracts. Such individuals as do not follow the retreating waters escape from the scorching rays of the African sun by burrowing in the mud, which is soon baked hard above them. There they remain, in a torpid state, until the return of the rainy season.

To us, in our onward course through the various groups of the animal kingdom, the Lepidosiren presents itself as a connecting link, and serves naturally to lead us from the Fishes to the Amphibia. Whether these great divisions are as distinct as they have hitherto been supposed is a question. Professor Owen has recently given expression to an opinion that all the cold-blooded vertebrate animals should form one great group.

Class II.-FROGS, NEWTS, \&c.

\section{AMPHIBIA.}

Naturalists are not agreed as to whether the Amphibia should form a Class, or be regarded as an Order of the 
class Reptilia. In deference to what is now the prevailing opinion, they are here ranked as a Class.

The Amphibia deposit eggs, from which the young are produced. The blood is cold. They breathe by gills and by lungs. The body is covered with a soft naked skin. The young undergo metamorphosis.

Possessing the power of breathing in water by means of their gills, and in air by means of their lungs, the term Amphibia is very expressive, for it implies that they are fitted alike for both elements.

They may be separated into two divisions-those which possess both lungs and gills throughout the entire period of life, and those which have gills in their young state, and acquire lungs as they approach maturity. The former group contains some ani-

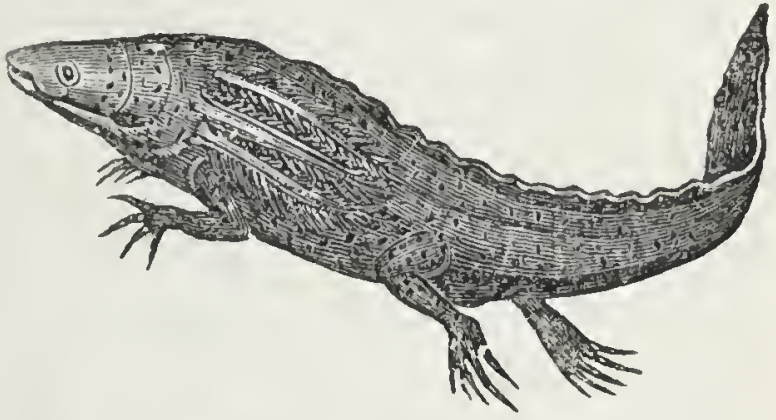

Fig. 144.-Axolotr. mals of very singular structure and habits; as the Axolotl (Fig. 144), the flesh of which is regarded as an article of luxury by the inhabitants of the city of Mexico, near to which it is taken.

The latter group has, however, especial claims on our attention; for in the Frogs, Toads, and Newts of these countries, we have the opportunity of watching the successive steps by which they become fitted for breathing air, instead of continuing to use gills.

The eggs of the common Frog are deposited at the bottom of a pool of water, each egg consisting of a black centre, surrounded by a covering of ghutinous matter. 
When the little Tadpole has burst from its prison, the leaf-shaped gills begin to appear, and increase rapidly in size. They are now objects of singular beanty under the microscope; for such is their transparency that the course of every globule of blood, as it passes up or down the main stem, or enters the inlets presented by each leaf, is distinctly visible. This period is, however, very brief. Soon, however, the tufted gills shrink in size until they are concealed, like the gills of fishes. The little Tadpole (Fig. 145)

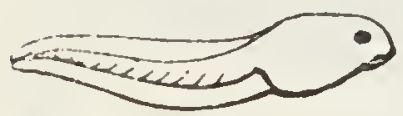

Fig. 145.

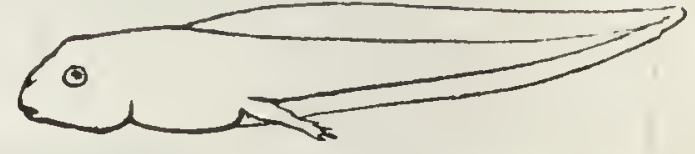

Fig. 146.

begins to feed on decaying vegetable matter; the tail becomes a large and powerful organ for locomotion, and a rapid increase takes place in the size of the body. After a time the hinder-feet appear (Fig. 146); then the fore-feet (Fig. 148); the tail shrinks; the form of the perfect animal is assumed (Fig. 147); the remaining vestige of the tail disappears (Fig. 149); and instead of an aquatic animal, breathing by gills, and feeding on

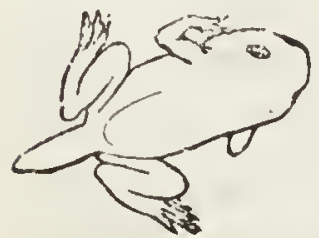

Fig. 147.

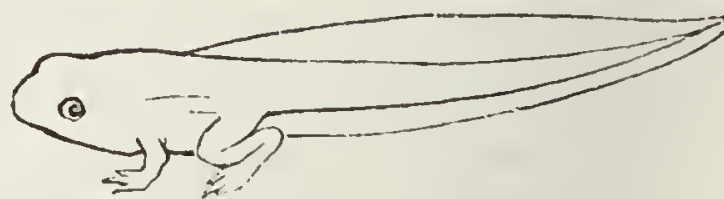

Fig. 148.

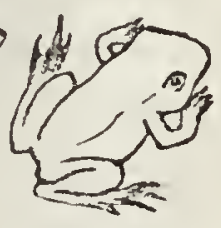

Fig. 149.

vegetables, we have one fitted for $d$ welling upon land, breathing by lungs, and feeding upon smaller animals, such as slugs and insects. 
In some of the countries of both temperate and tropical regions there are Frogs which, from their habitation, are called Tree-Frogs (Fig. 150). They are described as beautiful and active little animals, not unlike in their colours to those of the trunks and foliage, and fur-

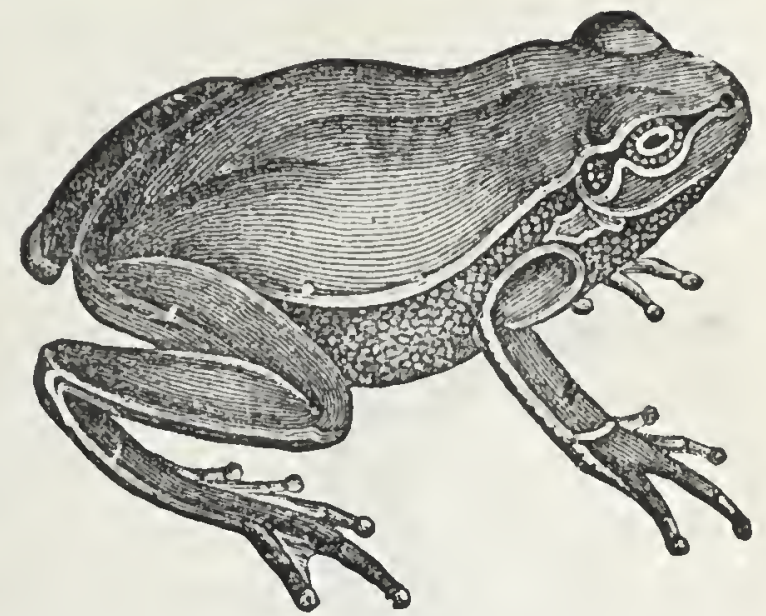

Fig. 150.-TREe-FroG. nished at the end of their toes with small cushions or pads, by means of which they can adhere to smooth surfaces.

The Frog is believed to have been introduced into Ireland in the early part of the last century. The common Toad is there unknown, its absence, according to popular tradition and song, being attributed to Saint Patrick. The smaller species, the Natterjack, is found in the county Kerry.

\section{CLASS III.-REPTILES.}

\section{REPTILIA.}

ReptiLes are cold-blooded animals, breathing by lungs only. The body is covered with scales or shelly plates. The young do not undergo metamorphosis. They are arranged in three orders: Serpents, Lizards, and 'Tortoises. 


\section{ORDER I.-SERPENTS.}

\section{OPHIDIA.}

The number of Serpents, like that of other reptiles, increases towards the torrid zone, while comparatively

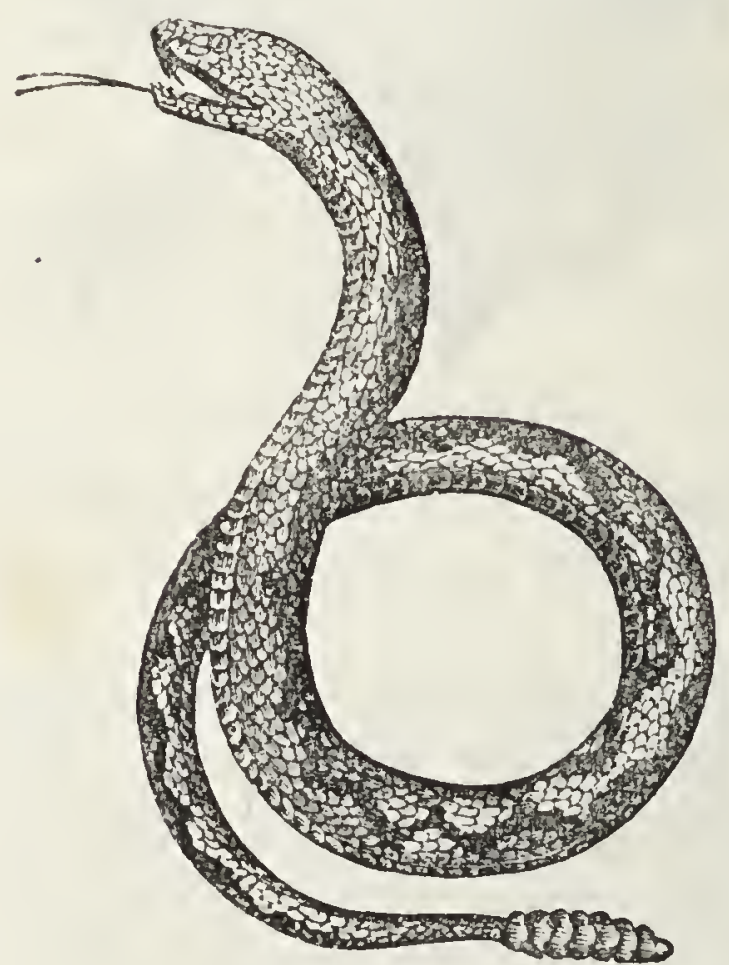

Fig. 151.-KATTLE-SNAKn. few are found in cold regions. Their bodies are remarkable for the ease with which they can bend: this is caused by the number of joints in the backbone or "spinal columu." In the Rattlesnake (Fig. 151) these joints amount to about two hundred; and above three hundred have been counted in the spine of the Viper. Some Serpents live amid the foliage of trees, some inhabit fresh waters, some poisonous tribes live in the seas of tropical Asia and New Holland, but by far the greater number live, on the land. There are at present about 400 known species, a large proportion of which are not venomous.

The gigantic Boa Constrictor belongs to those which are not venomous. It kills its prey by the enormous compression it exerts when coiled round the body of its victim, which it then proceeds to swallow entire.

Sir Emerson Tennent tells us that his official residence at Ceylon was occasionally entered by very 
unexpected visitors belonging to this class. "Serpents," he says, "are numerous on the hills, and as the house stood on a terrace formed out of one of its steepest sides, the Cobra de Capello and the green Carawella frequently glided through the rooms on their way towards the grounds. During the resicience of one of my predecessors in office, an invalid who lay for some days on a sofa in the verandah, imagined more than once that she felt something move under the pillow, and on rising to have it examined, a snake was discovered with a brood of young, which, from their being born alive, were most probably venomous. A lady residing in the palace adjoining, going to open her piano, was about to remove what she thought to be an ebony walking - stick that lay upon it, but was startled on finding that she had laid hold of a snake."*

The poison fangs with which the venomous tribes are furnished, have been described by Professor Jones as "constituting

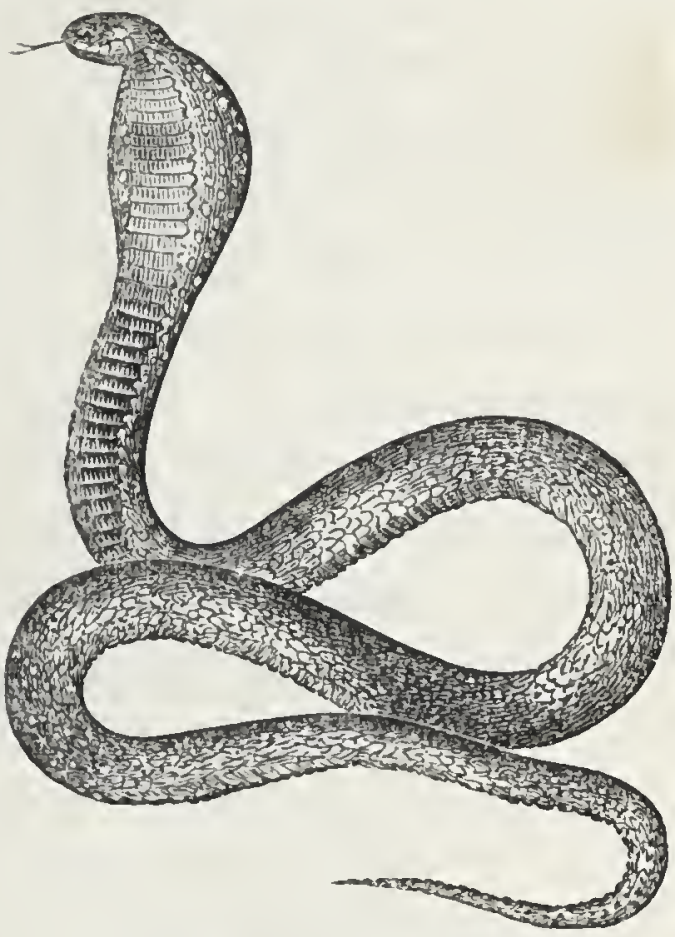

Fig. 152.-Egrptian NaJA. perhaps the most terrible weapons of attack met with in the animal creation." The poison itself is neither acrid nor burning. On the tongue it only produces a

* Tennent's Ceylon, vol. ï., p. 205. 
sensation like that of fatty matter, and it may be swallowed without danger; but, introduced into the blood in sufficient quantity, it causes death with fearful rapidity, though the power of doing so varies, according to the species and other circumstances.

The Naja or Asp (Fig. 152) is a species much used at the present time by the Egyptian jugglers in their exhibitions: it is one which also possesses a classical and historical interest, connected as it is with the death of the far-famed Cleopatra.

No Snakes of any kind whatever exist in Ireland. In England the harmless tribes are represented by the Common or Ringed Snake, and the venomous by the Adder or Common Viper. The injurious results of the bite of the latter reptile would appear to be much exaggerated. Professor Bell states that he has never seen a case which ended in death, nor has he been able to trace to an authentic source the numerous reports of such a termination. Both species lie torpid during the winter, and continue so until the return of a more genial season and a higher temperature again rouses them to activity. Hence the remark of the poet-

"It is the bright day that brings forth the Adder, And that craves wary walking."-ShaKspeare. 


\section{ORDER II.-LIZARDS.}

\section{SAURIA.}

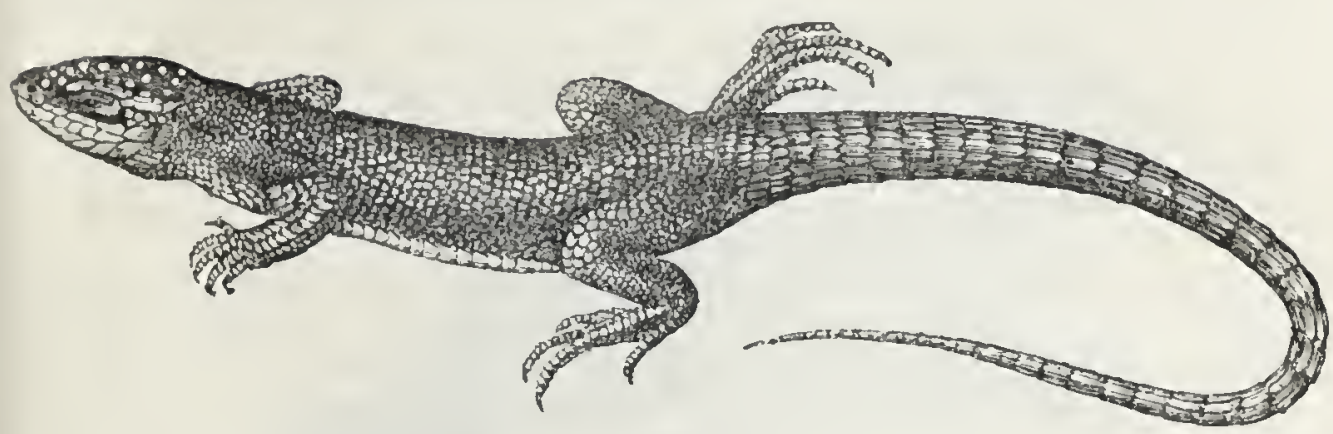

Fig. 153,-Green Lizard.

In this order the body and tail are elongated, the jaws are furnished with teeth, the skin is covered with scales, and the animals have generally four feet. The flesh of many of the foreign Lizards, when cooked, is white, and is relished as very good food. Humboldt has remarked that all the South American species within the tropics, and inhabiting dry regions, are esteemed as delicacies for the table. Such are the Iguamas, which are found only in the New World, and live among the branches of trees. Some of them measure so nuch as five feet in length, and their colour is a beautiful green of a variety of shades. They have a singular crest along the back, and under the chin a hanging pouch, which they can fill with air.

Perhaps, however, there are no reptiles which excite a greater degree of popular interest than Chameleons (Fig. 154). They are exclusively natives of the warm parts of the Old World, and exhibit several peculiarities of structure. Like other Lizards, they have five toes; but they are divided into two parcels, and thus 
adapted for climbing. The tail also serves as an instrument or means for grasping. 'The eyes have such independent powers of motion, that they can be turned into the most opposite directions at the same

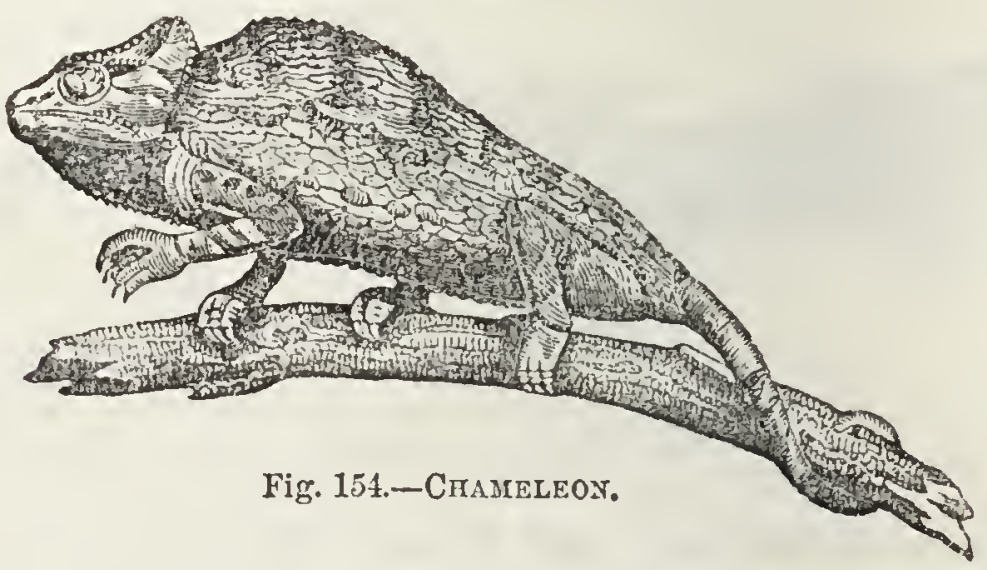

time. The tongue is of great length, and is darted out with unerring aim at their insect prey.

The singular changes of colour for which they have been so celebrated do not prevail to the extent set forth in a well-known poetical composition with which every school-boy is familiar. They are, however, sufficiently curious to have induced naturalists to endeavour to explain how they were effected. This has only recently been accomplished; and it is found to arise from a singular arrangement of the cells of the skin containing the colouring matter, and precisely like that which exists in the Cuttle-fishes.

The Lizards, which are regarded as the true representatives of the order, do not belong to any of the families yet mentioned, but to that to which the two species of English Lizards belong. They have long slender forked tongues; and are bright-eyed, active little creatures, often adorned with brilliant colours.

The ease with which the tails of some Lizards 
separate from the body is very remarkable, and excites the astonishment of any person unacquainted with this peculiarity. The following occurrence is narrated by Dr. J. L. Drummond:- "Being on the sea-shore at Pulo Bay, in Sardinia, and searching for specimens of natural history, I observed a large Lizard running for shelter under a heap of stones. I was just in time to seize it by the end of the tail; but suddenly the resistance made by the animal to my attempt to drag it from its hiding-place ceased, and I gave it up for lost; but as suddenly had cause for alarm myself, on seeing what appeared to be a small Snake leaping with great agility about my feet, and springing as high as my knee. I instantly started out of its way, and watched it at a-respectful distance, when I found that it was the tail of the animal, which I was not before aware could so easily separate."

From the most popular of the order we turn to the most formidable, the Crocodiles. Of these, the Alligators or Caymans are peculiar to America, the Gavials to Asia, and the true Crocodiles hold their head-quarters in Africa, but are not restricted to that continent. The Crocodile of the Nile formed one of the innumerable idols of the ancient Egyptians. His great strength is almost proverbial. "He esteemeth iron as straw, and brass as rotten wood. The arrow cannot make him flee; sling-stones are turned with him into stubble; darts are counted as stubble; he laugheth at the shaking of a spear." Yet this formidable reptile is endued with habits which render him one of the great benefactors of the human race; for he frequents the banks, of tropical rivers, feeds 
upon the bloated carcasses which come floating down the stream, and thus, by the removal of carrion, prevents the air from being tainted by decaying animal matter.

Sir Charles Iyyell, in his Second Visit to the United States of America, gives us the following interesting particulars respecting the nests of the Alligators at Savannah :-

"They resemble haycocks, about four feet high, and five feet in diameter at their bases, being constructed with mud, grass, and herbage. First they deposit one layer of eggss on a floor of mortar, and having covered this with a second stratum of mud and herbage, eight inches thick, lay another set of eggs upon that, and so on to the top, there being commonly from one hundred to two hundred eggs in a nest. With their tails they then beat down round the nests the dense grass and reeds, five feet high, to prevent the approach of unseen enemies. The female watches her eggs until they are all hatched by the heat of the sum, and then takes her brood under her care, defending them and providing for their subsistence. Dr. Sugenberger of New Orleans told me that he once packed up one of these nests with the eggs in a box for the Museum of St. Petersburg, but was recommended, before he closed it, to see that there was no danger of any of the eggs being hatched on the voyage. On opening one, a young Alligator walked out, and was soon after followed by all the rest, about a hundred, which he fed in his house, where they went up and down the stairs, whining and barking like young puppies." 


\title{
Order III.-TORTOISES.
}

\author{
TESTUDINATA.
}

"And in his needy shop a Tortoise hung, An Alligator stuffed, and other skins Of ill-shaped fishes."-ShaKspeare.

LET it not excite surprise that, in the passage just quoted, the word "fishes" should be applied to reptiles. It is still used by the uneducated in speaking of warmblooded animals which, like the Whale, live in the sea. Tortoises are distinguished from all other reptiles by having the body enclosed between two shields, with openings for the head, the tail, and the four legs. The jaws are horny and without teeth. They may be conveniently arranged with reference to their habits, as Land Tortoises, Fresh-water Tortoises, and Turtles or Marine Tortoises.

Among the latter are the Green Turtle, which is so highly prized by epicures, and the Hawk's-

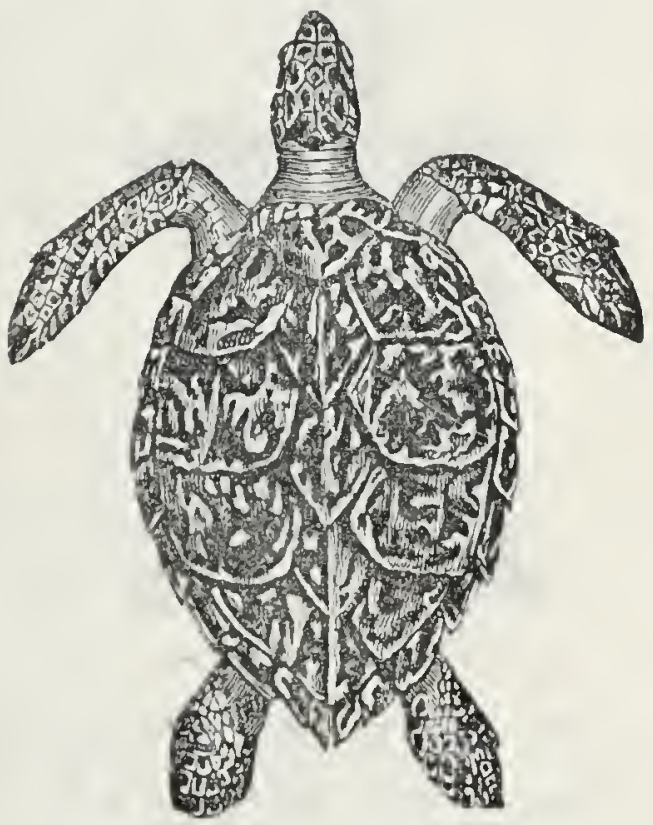

Fig. 155.-HaWK'S-EILL TURTLE. bill Turtle (Fig. 155), which supplies the valuable substance known as the Tortoise-shell of commerce. The form of the body is admirably adapted for progress through the water, and their feet are formed into 
oars of the most perfect construction; so that the ease and swiftness of the motions of the animal in water remind the spectator of the progress of a bird through the air.

Various species of Marine Turtle resort annually in immense numbers to the Island of Ascension, and the shores of the Gulf of Florida, for the purpose of depositing their eggs in holes, which they scrape on the beach for that purpose.

The River Tortoises have webbed feet, and are entirely carnivorous, living upon flesh of various kinds. The Land Tortoises (Fig. 156, 157) have feet with

\section{LAND TORTOISES.}

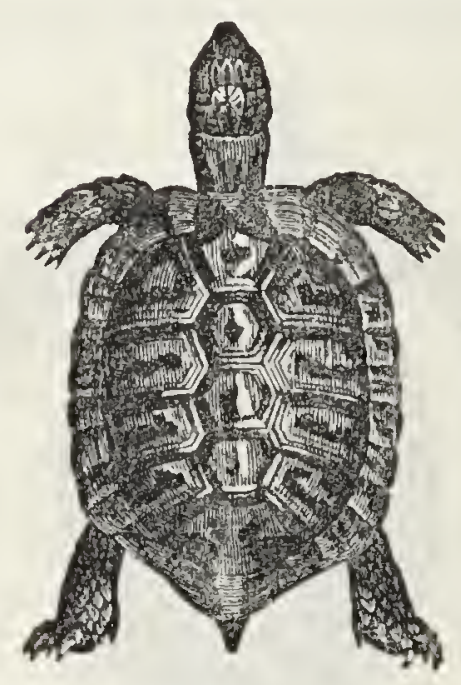

156.-Upper Surface.

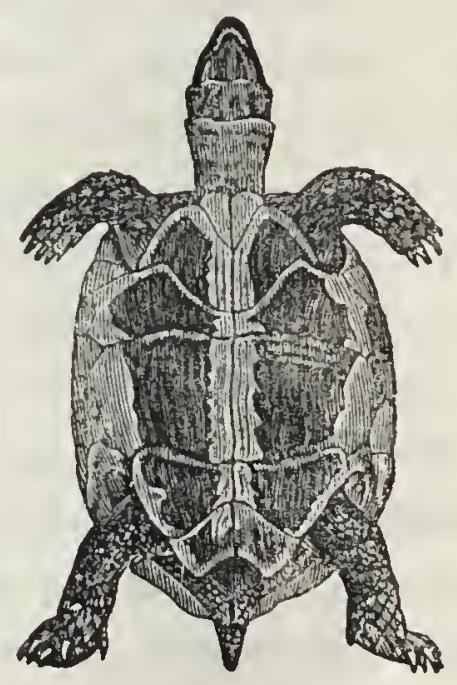

157.-Lower Surface.

short claws, and are altogether herbivorous, or, in other words, subsist on regetable food. They are remarkable for their great length of life; and also for the weight which they can carry with apparent ease.

Mr. Darwin mentions the great abundance of Tortoises in all the islands of the Galapagos Archipelago. These creatures sometimes grow to an immense size: 
he had been told of some so large that six or eight men were required to lift them from the ground. They are fond of water, travel great distances for it to springs on the elevated grounds, and drink large quantities. From this circumstance, it occasionally happens that the inhabitants of the lower district, when overcome with thirst, will kill a Tortoise for the sake of the contained water: "They believe," says Mr. Darwin, "that these animals are absolutely deaf; certainly they do not hear a person walking close behind them. I was always amused when overtaking one of these great monsters, as it was quietly pacing along, to see how suddenly, the instant I passed, it would draw in its head and legs, and, uttering a deep hiss, fall to the ground with a heavy sound, as if struck dead. I frequently got on their backs, and then, upon giving a few raps on the hinder part of the shell, they would rise up and walk away; but I found it very difficult to keep my balance."

\section{CLASS IV.-BIRDS.}

AVES.

"Birds, the free temants of land, air, and oceanTheir forms all symmetry, their motions grace."

Janes Montgonery.

BIRDs are warm-blooded animals, and are produced from eggs. They breathe by lungs, have a heart consisting of four cavities, and a body covered with feathers. 
We see in birds the power of flight in its fullest perfection. This alone would separate them from any other class of vertebrate animals. It is, of itself, a singular and interesting subject connected with the feathered tribes. The entire framework of the body shows a beautiful arrangement having reference to this object, and combining strength and lightness.

The bones of the Eagle, the Swallow, and all others possessed of great powers of flight, are hollow, and can, at the pleasure of the bird, be filled with air, which,

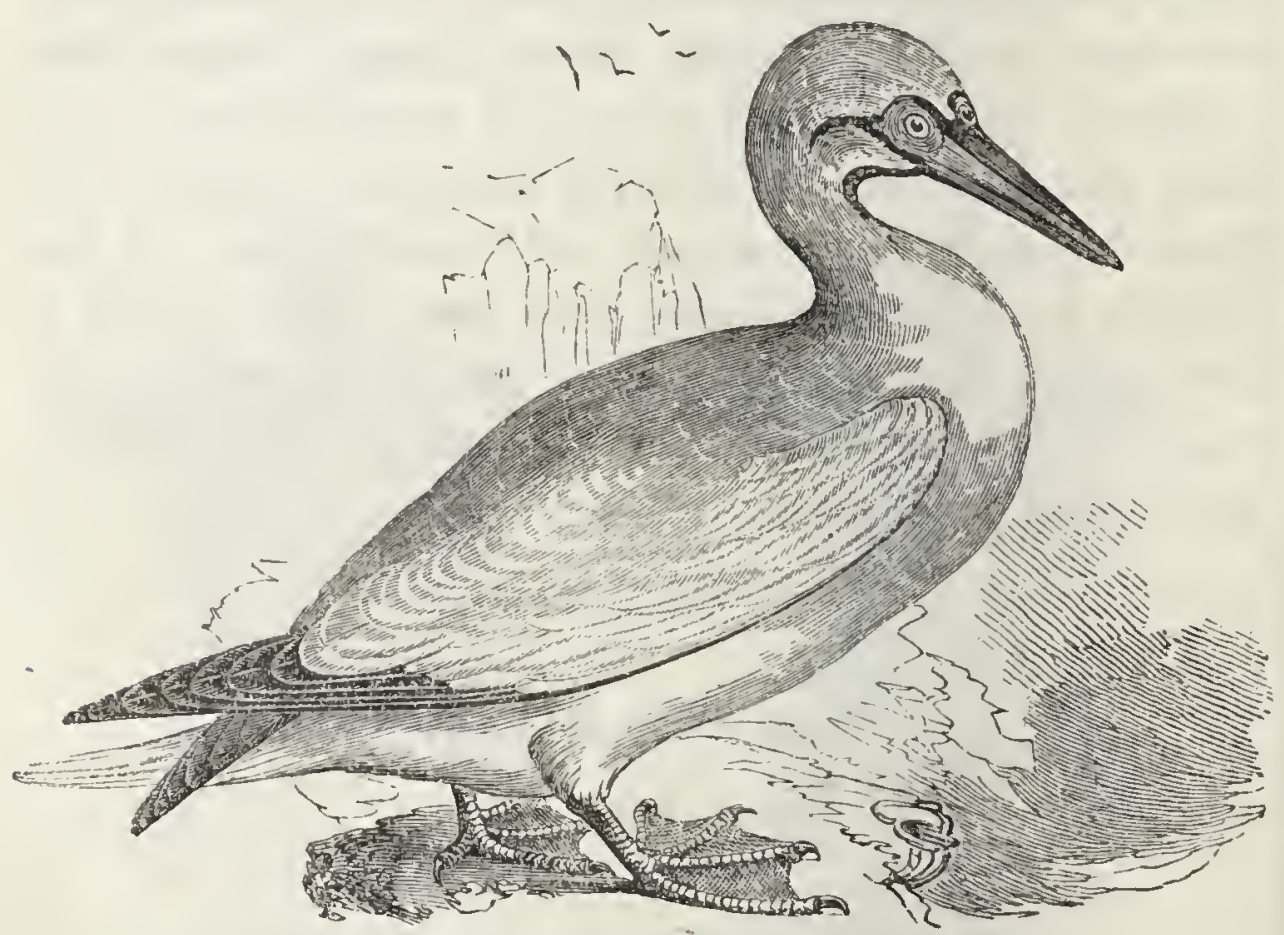

Fig. 158.-Gannet.

because of the great heat of their blood, is particularly buoyant. Birds, too, are furnished with a covering of feathers, which differs so much in the various tribes as to present every possible variety of tint and texture.

An illustration of the buoyancy of birds, and the power of their descent, is furnished by the Gannet or 
Solan Goose (Fig. 158) of our own shores. When searcling for food it flies a sliort way above the surface of the water: on seeing a fish, it rises into the air, and descends with such rapidity and force as to secure the prey. Some idea of the power of its descent may be formed from a circumstance related by Pennant. One of these birds, flying over Penzance, saw some Pilchards spread out upon a fir plank about an inch and a half thick, and which was used in the curing of the fish, and darted down with such violence that it struck its bill quite through the board, and broke its neck. Pennant adds, that these birds are sometimes taken at sea by a similar deception, a fish being fastened for the purpose to a floating plank.

All birds do not, however, possess the power of prolonged or powerful flight; but some, whose wings are unfit to bear them through the air, have robust legs, well adapted for running. Such is the Cassowary (Fig. 159), a native of Java and its adjacent islands. It is a stout-bodied bird, measuring about fire feet high when standing erect. Still better known is the Ostrich of the sandy deserts of Arabia and of the African continent; it exceeds in stature any bird now living, attaining occasionally the height of eight feet. Its great muscular strength, joined with the length of its powerful legs, enables it to run with astonishing swiftness, and even to distance the fleetest Arabian horses.

The stomach of birds differs greatly according to the nature of their food. In those which live on flesh it is thin and membranous, but in others the sides are of great thickness, and being moved by powerful muscles, act as a mill in grinding down the food. The stomach 
in this thickened state is well known as the gizzard, and its action is aided by small pebbles, and other hard substances, swallowed by the bird. This instinctive action is one well known in our common barn-door fowl; and in the Ostrich it prevails to such an extent that in the stomach of one were found pebbles enough to fill a large glass bottle. As this bird will swallow

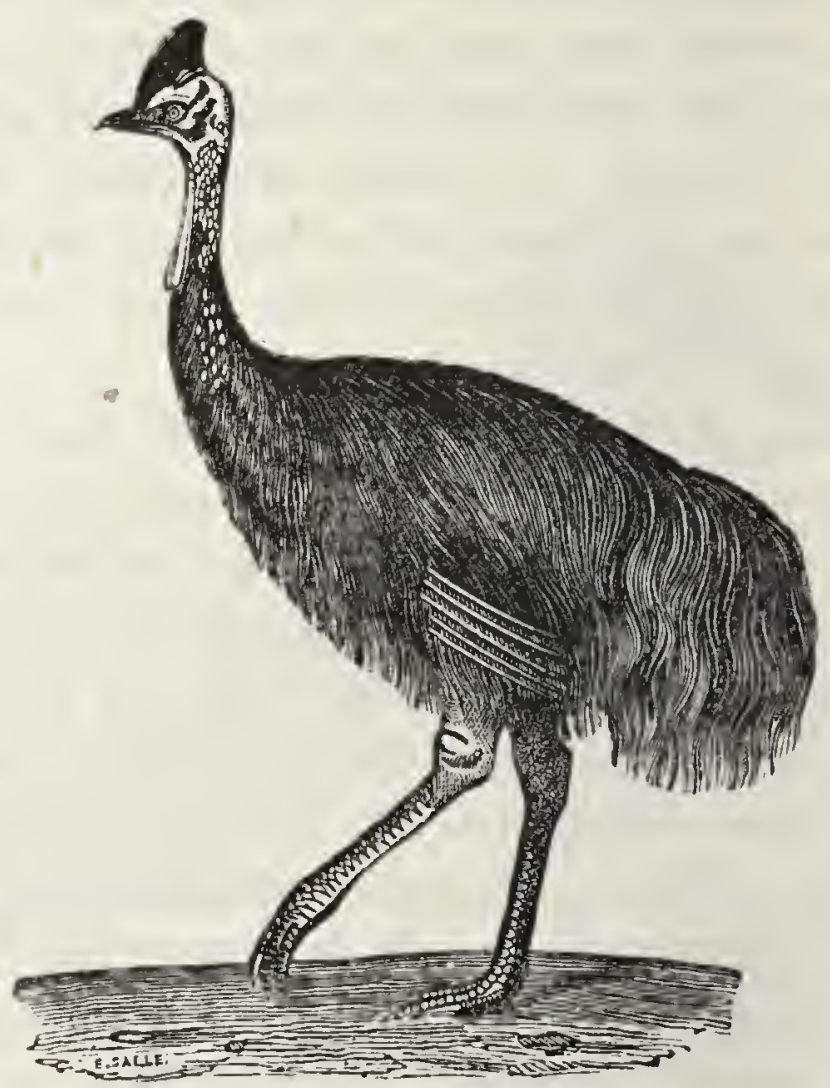

Fig. 159.-Cassowarr.

metals with equal readiness, popular belief in former times went so far as to assign to it the power of digesting these substances; and many are the allusions, in the older writers, to this supposed power of "the ironeating Ostrich."

Birds possess in a high degree the sense of sight; 
and the eye is so admirably adapted to their wants that it is suited for vision at the great height to which birds so:tr, and no less fitted for vision near at hand. It has three, not troo eyelids: the third one, when not in use, lies in the inner angle of the eye.

Their sense of smell is also very remarkable, and various experiments have been tried to ascertain the extent to which it exists in different species. It has been a doubtful matter whether Vultures are guided to the carrion on which they feed by the sense of sight or that of smell; but there seems no good reason for doubting that both senses are made to contribute to the welfare of the birds by directing them to their prey. The far-sighted eye sees it from the clouds, and the flight of the Vulture, as it descends to the feast, reveals the fact to its brethren. And, again, when near at hand, under the screen of cliffs or the thick vegetation of forests, the sense of smell reveals the lidden carcass, and tempts around it those who act an important part in its removal.

There are many other birds which, like the Vul-

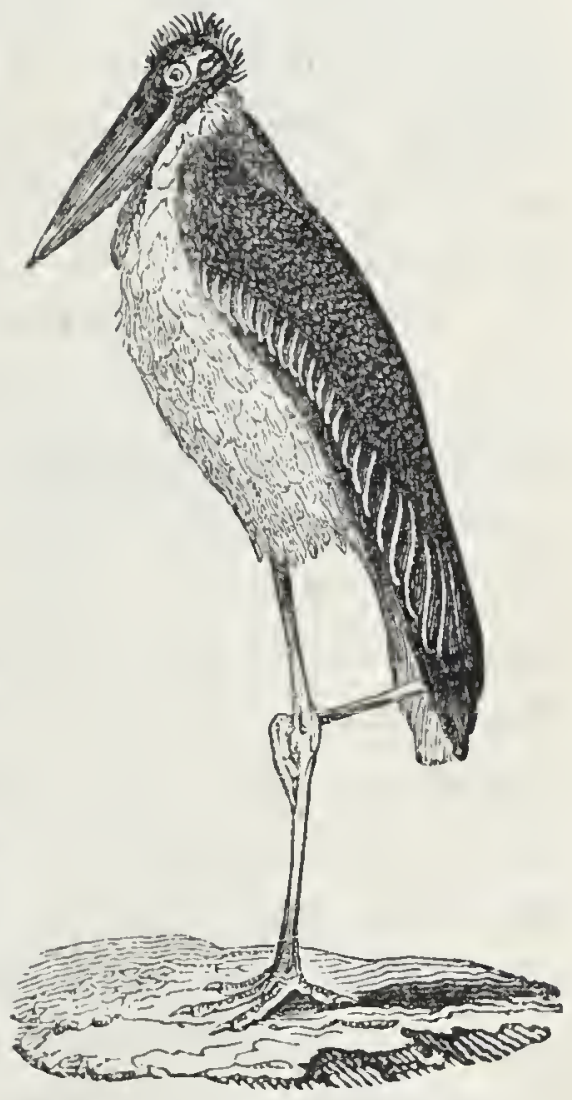

Fig. 160.-Povched Adjutaxt. tures, assist in freeing the surface of the earth from decaying animal matter. Thus, in India, there is one 
whose services are no less valuable, a gigantic kind of Crane, called the Adjutant (Fig. 160). This bird is so very useful as a scavenger that it is not only permitted to remain undisturbed, but is even regarded with reverence. It is a voracious feeder, and gulps down its food whole. It has been known to swallow a leg of mutton of five or six pounds weight; and Sir Everard Home states that in the stomach of one, a land tortoise, ten inches long, and a large black cat, were found entire.

At the arproach of winter there are various birds which make their appearance pretty nearly at the same time each year, and leave us early in the spring. They have arrived from regions farther north, and have made our islands the southern limit of that periodical change of residence to which we give the term migration. There are others whose appearance in spring we welcome, not only because of the beauty of their flight or their plumage, or the cheerfulness of their notes, but as the heralds of brighter skies and returning verdure. These stay with us during the summer, and then wing their way to the south. The British islands are the northern limit of their migration. It is now known that the greater number of these summer birds leave these kingdoms for the north and west of Africa, whence they return every year, with such punctuality that their appearance may be looked for with confidence within a day or two of the usual time.

These simple facts are nearly all we can be said to know with certainty upon the subject. We are unable to explain their cause, and should therefore candidly 
admit our ignorance. The wisest course is to look upon birds as acting under an impulse implanted in them by the Creator, and winging their flight under His guidance. Such a reflection will make us listen with higher pleasure to the roice of the Cuckoo, and look with increased interest on the graceful flight of the Swallow. The experience of every day teaches that "the Stork in the heavens knoweth her appointed time, and the Turtle and the Crane (Fig. 161) and the Swallow observe the time of their coming:"

The nests of our native birds exhibit great variety in situation, structure, and materials. Some of those belonging to foreign coun-

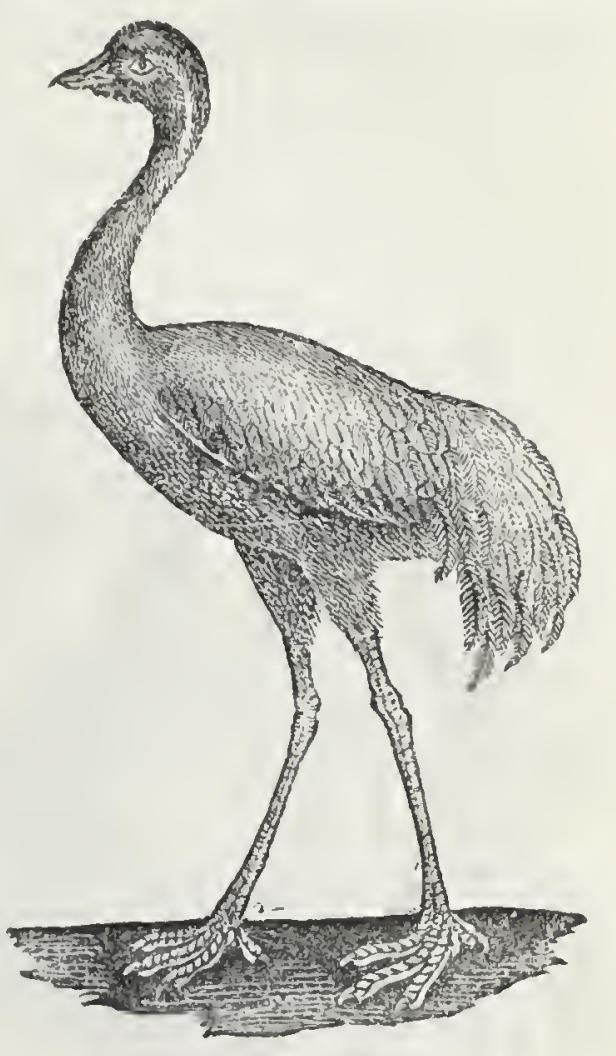

Fig. 161.-Crave. tries appear even more ingenious, though of course, not better adapted to the wants of their occupants. Thus, the nests of the Baya, a bird of Hindostan, are formed of long grass woven together in the shape of a bottle (Fig. 162), and suspended to the extremity of a thin branch, to secure the eggs and young brood from serpents, monkeys, squirrels, and birds of prey. These nests contain several chambers for different purposes.

Another species, called with great justice the Tailorbird, collects from the cotton-plant fibres of cotton, and with them sews two leaves together, the bill being 
used as a needle. The nest is concealed in the space between the two leaves (Fig. 163).

When so much skill and labour are shown in the nests, it may well be supposed that the young, for whose especial use they are formed, are not neglected;
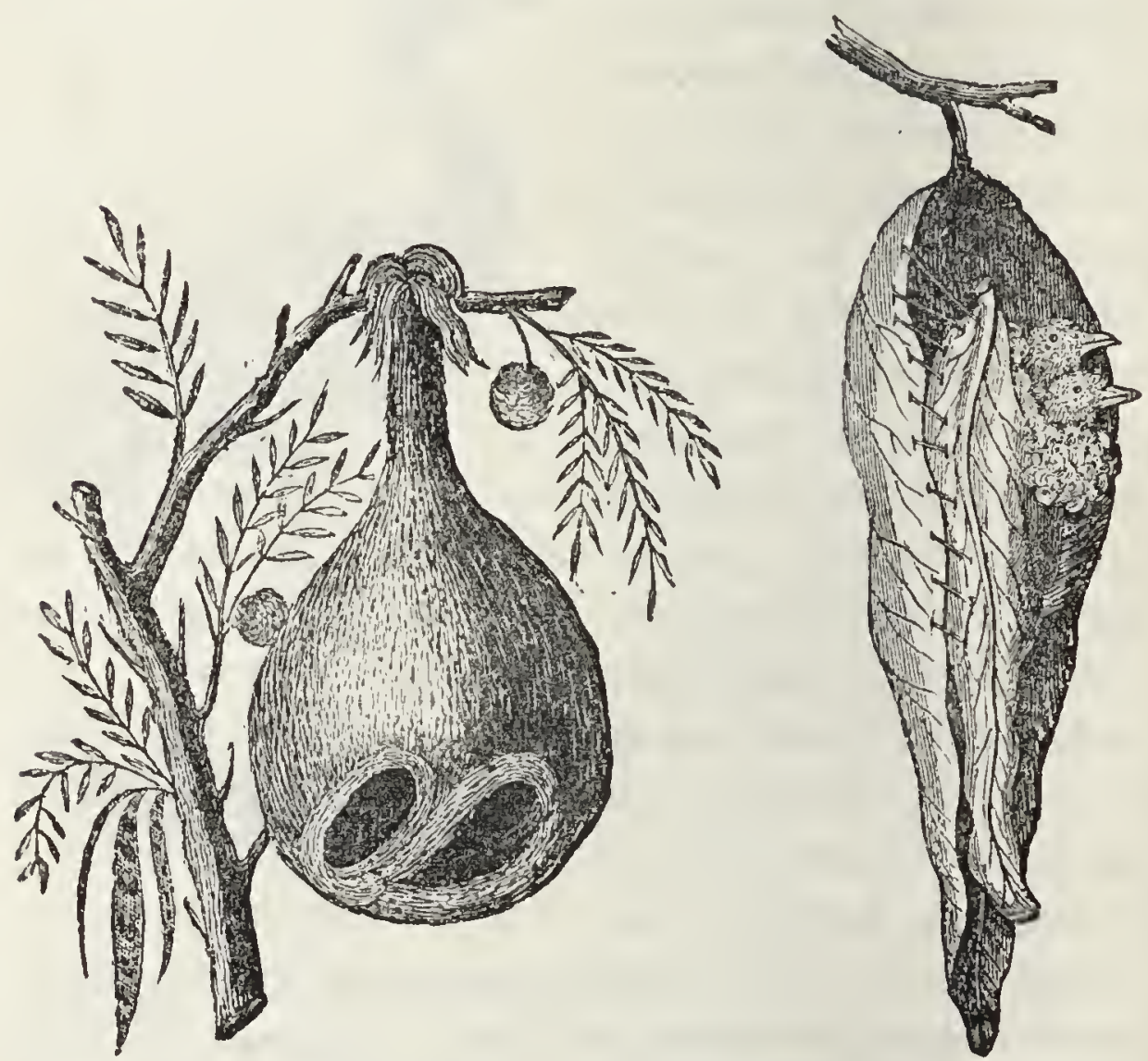

Fig. 162.-Nest OF THE BaYA.

Fig. 163.-Nest OF the TAILOR-BIRD.

and in fact they are objects of the most ceaseless care. The attention bestowed upon them is so continual, and so full of tenderness, that it is not in the power of language to convey a more vivid idea of affectionate watchfulness than is implied by a simple reference to their ordinary habits.*

* The reader will recall to mind, as an example of this, the memorable words_"O Jerusalem, Jerusalem! which killest the prophets, and 
According to the most recent authorities upon the subject, there are about $\tau, 500$ different species of birds known to naturalists at the present time. These are divided into many genera, founded upon differences of structure. The shape of the organs by which the food is taken always indicates the form and structure of those by which it is swallowed and digested. For example, if we meet a bird that, has a short beak and curved claws, like the eagle, we shall find that it has also a wide gullet and a membranous stomach, fit for swallowing and digesting flesh; so that, in point of fact, "the external parts afford an index to the internal."

Upon these principles the following classification has been adopted, all birds being arranged in five orders :-

I. Birds of PrEY, as...Vultures, Eagles, Owls (Raptores).

II. Perchers, as ......... Sparrows, Linnets, Crows (Insessores).

III. Scraping Birds, as Pheasants, Fowls (Rasores).

IV. Waders, as .............Herons, Bitterns (Grallatores).

V. Swrmmers, as .........Geese, Divers, Gulls (Natatores).

\section{Order I.-BIRDS OF PREY.}

\section{RAPTORES.}

THese Birds are distinguished by a strong hooked bill and stout muscular legs; the toes are rough below, and armed with powerful, sharp, curved talons. They stonest them that are sent unto thee: hor often would I have gathered thy children together, as a hen doth gather her brood under her wings, and ye would not." - LUKE siii. 34 . 
are arranged in three families: the Vultures, the Falcons, the Owls.

I. Vultures.-Vultures, in most cases, have the claws less curved than either Falcons or Owls, the feet generally naked, and the head in a greater or less degree without feathers. None of them are natives of these countries.

Such being the case, the capture of the Griffon Vulture near Cork Harbour, in 1843, was an interesting occurrence. This bird, said to be the largest European bird of prey, is a native of the Alps and Pyrenees, and it gorges upon carrion, rarely quitting the prey while a morsel of flesh remains; so that it is not uncommon to see it perched upon the dead body of an animal for several successive days. It never attempts to carry off a portion, even to satisfy its young, but feeds them by disgorging the half-digested morsel from its maw. It frequents the North of Africa, as well as Europe, and assembles in considerable numbers when the carcass of some large quadruped forms the banquet.

There are many species of Vulture; perhaps the most celebrated is the Condor, the largest of all birds

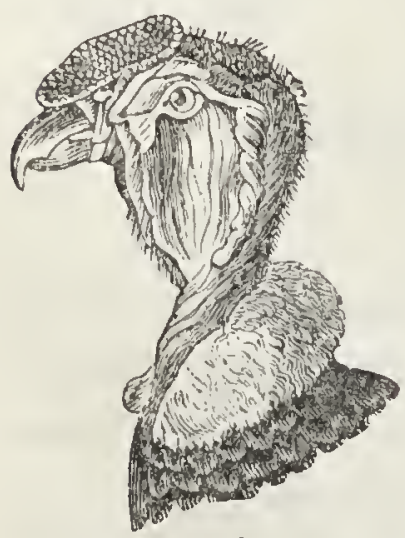

Fig. 164.-CONDOR. of prey. Exaggerated ideas of its size were at one time so current that it was compared to the Roc of eastern fable. The neck has fleshy appendages (Fig. 164), somewhat resembling those of the Turkeycock. Beneath is a white ruff of downy feathers, forming the line of separation between the naked skin above and the true feathers covering the body below. 
II. Falcons.-This group is distinguished from the preceding by the sharp curved claws, and by the head being in all cases covered with feathers. It includes the Eagles, Falcons, Kites, and Buzzards.

Two species of Eagle, the Golden and the Whitetailed, are known as resident in these countries. The White-tailed or Cinereous Sea Eagle seems, in its habits, to approach more nearly to the Vultures. To the Golden Eagle, therefore (Fig. 165), let our attention be directed.

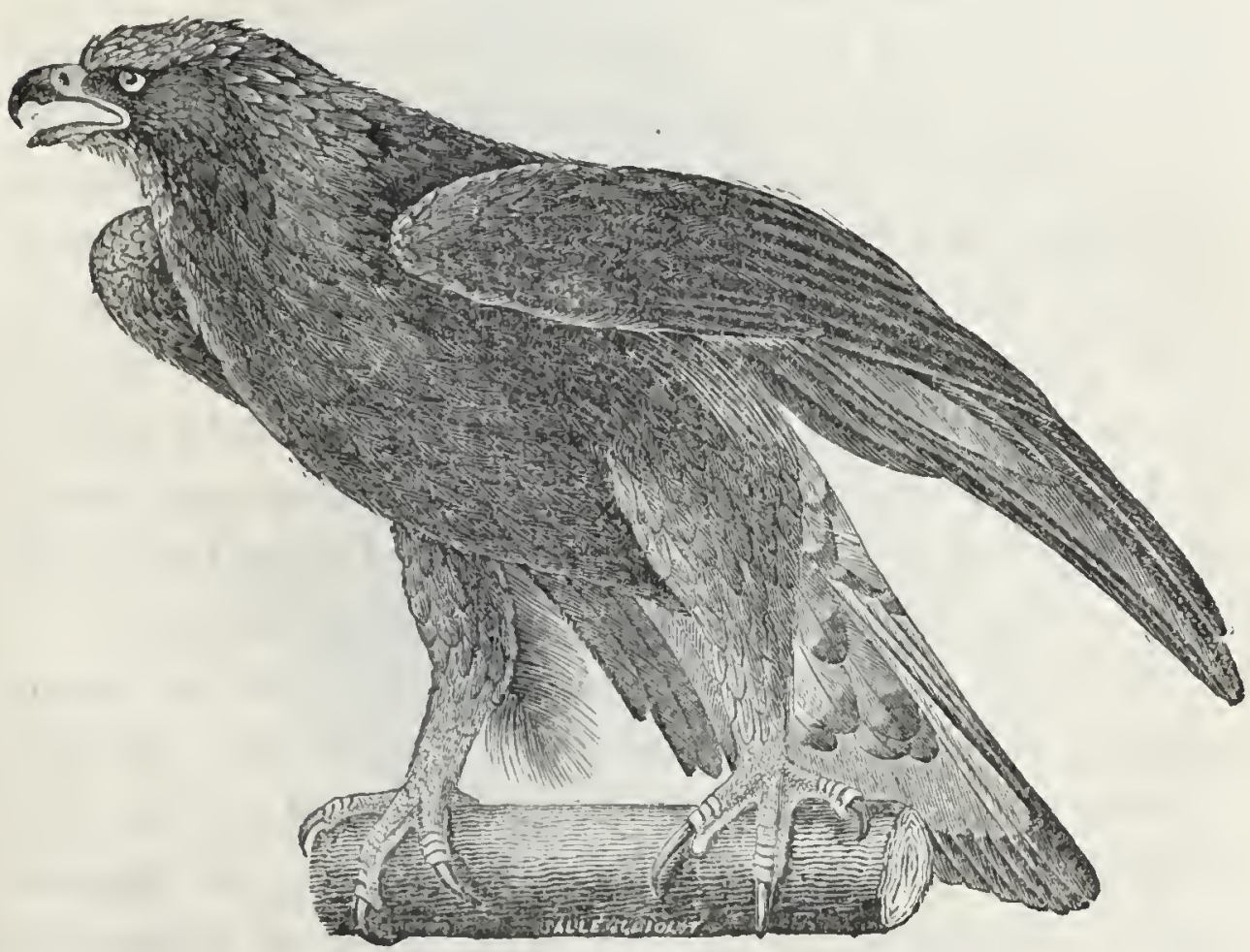

Fig. 165.-GoLdEN EAGLE.

Mr. Selby, in his splendid illustrations of British Ornithology, gives two figures of this bird in different attitudes: these figures have been described by a reviewer of that work in the following vivid terms, which convey to the mind of the reader an idea both 
of its aspect and its habits:- "The Golden Eagle leads the van of our birds of prey, and there she sits in her usual carriage when in a state of rest. Her hunger and her thirst have been appeased-her wings are folded up in dignified tranquillity - her talons, grasping a leafless branch, are almost hidden by the feathers of her breast-her sleepless eye has lost something of its ferocity-and the royal bird is almost serene in her solitary state on the cliff."

"But, lo, the character of the Golden Eagle when she has pounced and is exulting over her prey! With her head drawn back between the crescent of her uplifted wings, which she will not fold until that prey be devoured-eye glaring with cruel joy-neck plumage bristling-tail feathers fan-spread, and talons driven through the victim's entrails and heart-there she is new alighted on the edge of a precipice, and Fancy hears her yell and its echo." "The week-old Fawn had left the Doe's side but for a momentary race along the edge of the coppice-a rustle and a shadow, and the burden is borme off to the cliffs of Ben Nevis."

So great is the quantity of food they collect, when rearing their young brood, that a poor man in the county of Kerry got a comfortable subsistence for his family, during a time of famine, by robbing an Eagle's nest. A similar occurrence took place at Glenariff, county of Antrim, in the early part of the present century. "One of a pair of Eaglets, taken from a nest there, was so placed that during the summer its parents supplied it with Rabbits and Hares in such abundance that its owner obtained a sufficiency of animal food besides for himself and family." 
Of the true Falcons there are six British species; and of these the most celebrated is the Peregrine (Fig. 166). It is this species which, in former times, was so much used in these countries for hawking. 'To train them for this amusement required a great amount of care, skill, and patience. They were taught to come at the "call," or attend to the "lure" of the keeper. They were carried to the field upon "the fist;" a thick,

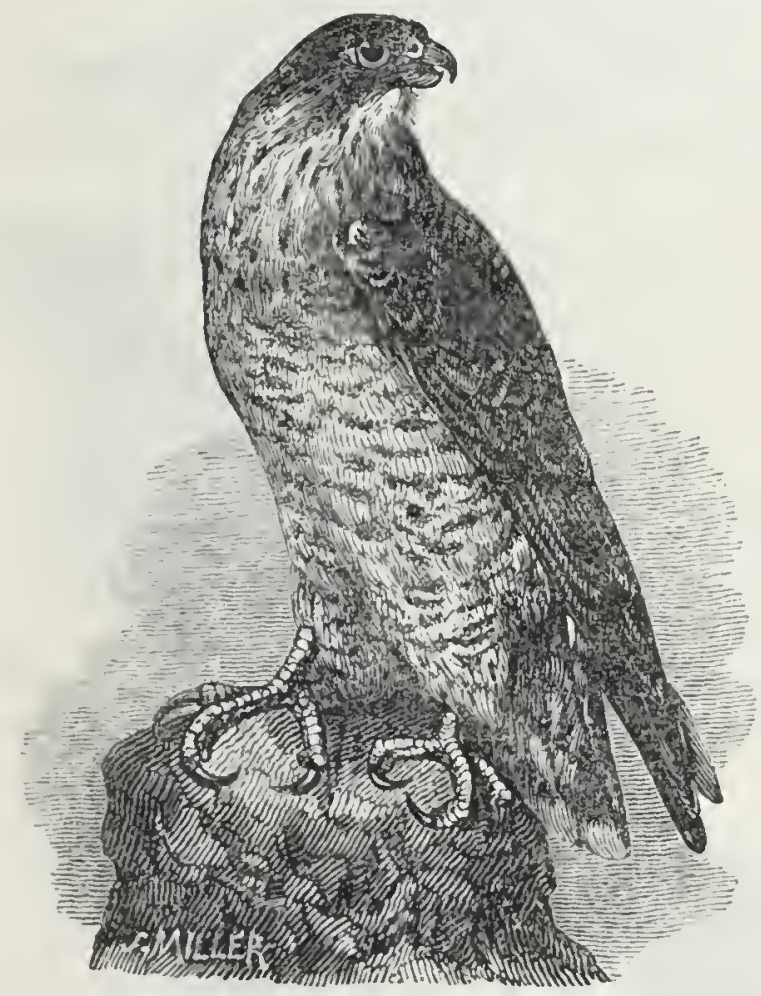

Fig. 166.-PERegrine Falcos.

and often a highly ornamented glove being used to prevent the hand from receiving injury from the strength and sharpness of the claws. At such times their eyes were covered, or "hooded," with a leather covering, usually surmounted by a small ornamental plume of feathers. Bells of brass or silver were attached to the legs; and through small rings, likewise 
fixed there, leathern or silken strings were passed, and wound round the liand of the Falconer until the time for "casting off" the bird. It tried in all cases to soar above and pounce upon the prey, which it transfixed with its powerful talons.

The rapid flight of the Falcon is very remarkable. An instance is recorded of one belonging to Henry IV., King of France, which crossed from Fontainebleau to Malta, a distance of not less than 1,350 miles, in twenty-four hours. In this case, supposing it to have been on the wing the whole time, its rate of flight must

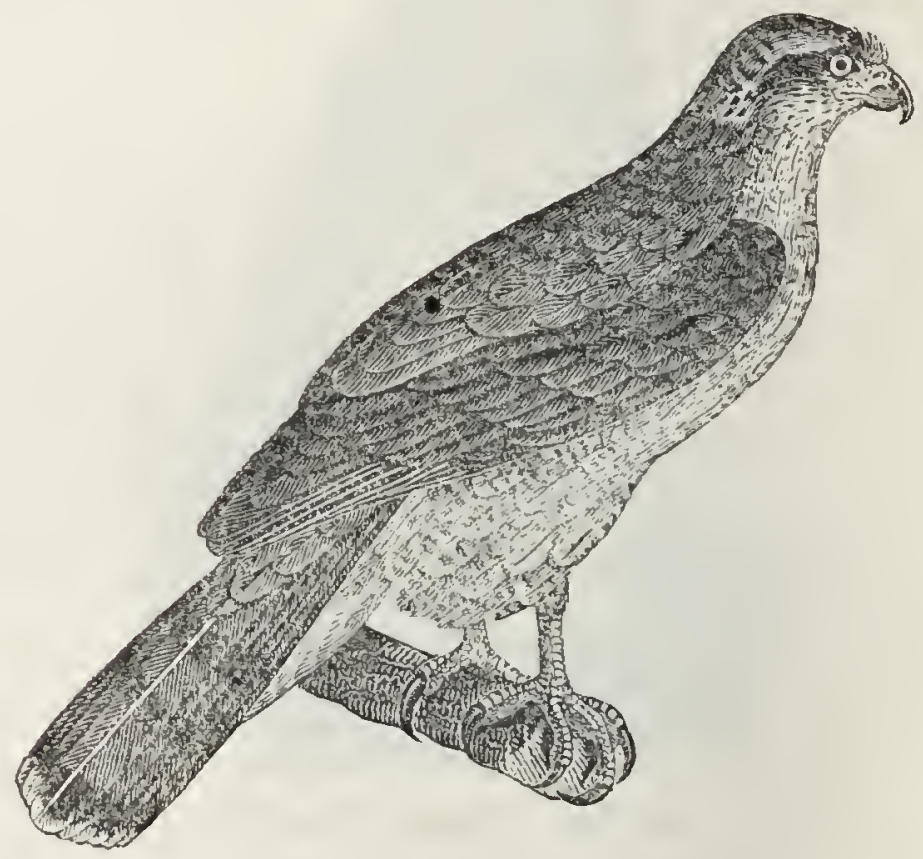

Fig. 167.-Gos-HAWK.

have been nearly sixty miles an hour; but as Falcons do not fly by night it was probably not more than sixteen or eighteen hours on the wing, and must, therefore, have gone seventy or eighty miles an hour.

The Gos-hawk (Fig. 167) is equal in size to the largest of the Falcons, differing in this respect from 
the Sparrow-hawk, which is the only other British species. The flight of the Gos-hawk is low, and it was formerly flown at lares, rabbits, grouse, and partridges.

The Kite (Fig. 168) is easily distinguished, even when at a distance on the wing, by its long and

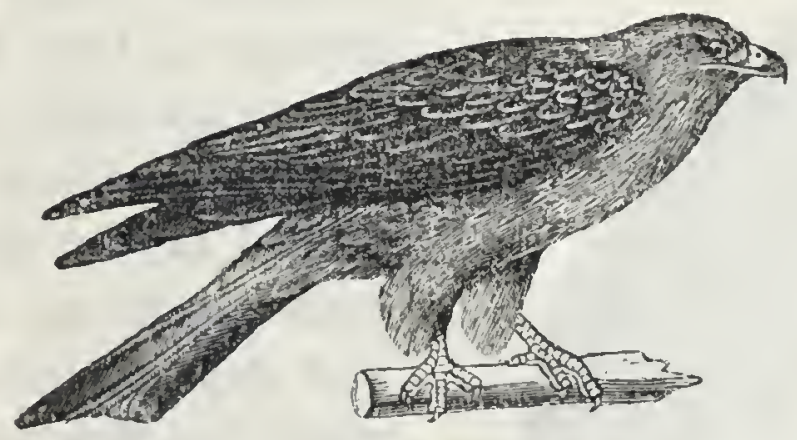

Fig. 168.-Ǩite.

forked tail, and by its easy and graceful flight. It is a bird of comparatively rare occurrence in England, and very rare in Ireland, though the name is applied to other species of the family, and particularly to the common Buzzard.

III. OwLS. - The nocturnal birds of prey form the third and last division of the present order, and constitute the well-marked family of the Owls. In the dusk of the evening they sally forth, with eyes cminently adapted for the diminished light, and with wings whose movement is so inaudible that, to use the words of an eloquent writer, "a flake of snow is not winnowed through the air more softly silent." Their strange appearance, grotesque attitudes, discordant screams, or continuous hootings, have caused them to be regarded by the uneducated as birds of ill 
omen, and accordingly they are frequently referred to as such by our poets,-

"The Owl shrieked at thy birth, an evil sign."-Sirarspeare.

Owls differ much in size, some even approaching to that of the Eagles. Among these the Snowy Owl

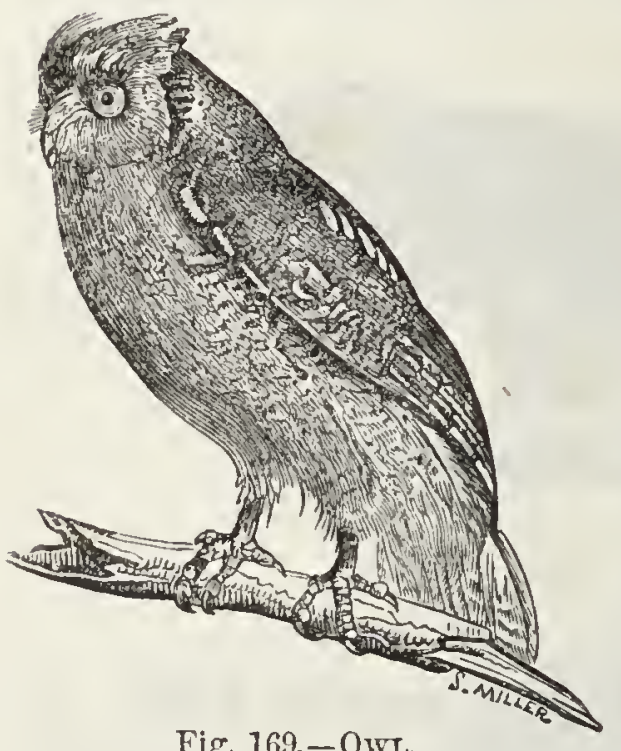

Fig. 169.-0wL. stands conspicuous: it is a native of high northern latitudes, but has been taken on many occasions in these countries. It flies abroad in the daytime as well as in the twilight, and has greater swiftness when on the wing than any other member of the family. It feeds on birds, quadrupeds, fishes, and even carrion; and can swallow entire animals of the size of a grouse, or a young rabbit.

In these particulars it presents quite a contrast to the habits of the White or Barn Owl, our most common native species. These birds frequent unoccupied buildings of any kind. The "ivy-mantled tower" is a congenial abode. They leave their retreat about an hour before sunset, to hunt for mice, which form the principal food of themselves and their young; and in doing so they "beat the fields over like a setting dog." The numbers of mice destroyed by a breeding pair of Owls must be enormous, and the service they thus perform very great to the farmer, the planter, and the gardener. In one instance 
where the Owls had been nearly destroyed by means of pole-traps placed about the fields, rats and mice increased to such an extent, and committed such havoc, that the proprietor was obliged to have all the pole-traps taken down; and the Owls being allowed to increase again, the number of rats and mice as quickly diminished.

Mr. Thompson mentions that a pair of White Owls in Belfast had their nest and young in a loft which was occupied by Pigeons. On the shelf beside the young Owls, the number of dead mice and rats observed remaining after the night's repast, varied from six to fifteen. The Owls made no attempt to injure either the Pigeons or their young; and there is strong reason to believe that it is only in the dearth of other prey that this Owl attacks any of the feathered tribe.

\section{Order II.-PERCHING BIRDS.}

INSESSORES.

Is consequence of the great number of species comprised in the present order, it is divided into four groups, and these are again subdivided into families, genera, and species. The four groups are distinguished by character's connected with the form of the beak or of the foot. Those birds which, like the Thrush and the Robin, have on the upper mandible of the bill a notch or tooth (Fig. 170), constitute the group of toothbilled birds. Those which, like the Sparrow, have the bill of a conical shape (Fig. 171), form another group. 
The third consists of those which are remarkable for their powers of climbing. In them the toes are most ustially arranged in pairs, two turned forwards and two backwards, as may be seen in the foot of the Cuckoo or Woodpecker (Fig. 178). The fourth is com-

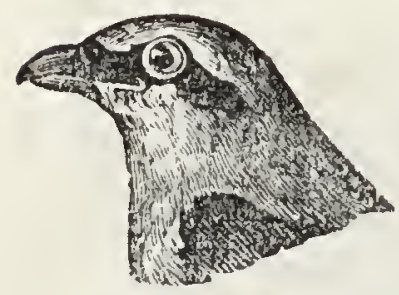

Fig. 170.

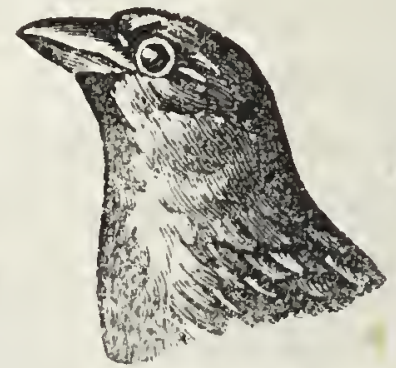

Fig. 171.

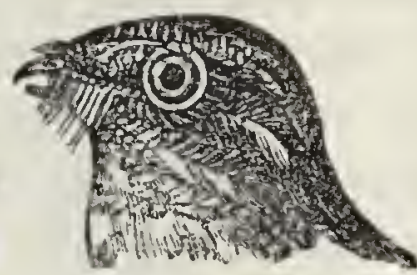

Fig. 172.

posed of those whose beak is so wide and gaping that it appears as if cleft: the Swallow and the Swift are familiar examples of this structure. It may also be observed in the Goat-sucker (Fig. 172), a bird which popular credulity has accused in Italy of sucking goats: and here of sucking cows, and inflicting a fatal distemper upon weaning calves. We have thus four tribes of perching birds:-

I. Tooth-BILLED, .......... Dentirostres.

II. Conical-BILled, ....... Conirostres.

III. Climbers, ..................Scansores.

IV. Gaping-dilled...........Fissirostres.

Tribe I.-Tooth-BILled Birds.-The family of the Thrushes includes the Water Ouzel, the Missel Thrush, and the Fieldfare, a migratory species that arrives from the north in the month of October, and remains here in large flocks during the winter. Two species are, however, particularly celebrated for their powers of song, namely, the Song Thrush and the Blackbird, "the Mavis and Merle" of the Border Ballads. 
The next family contains, however, one species which is without a rival for first-rate song-the Nightingale. The notes of woe which poets have attributed to this bird are altogether fanciful: the song, in reality, is not the expression of sorrow, but that of joy; and it proceeds not from the female bird, but from the male, who thus woos his mate or cheers her in the performance of her maternal duties.

To the same family belongs the Robin Redbreast, a bird that abore all others appeals to our kindly feelings, and to recollections which the wear and tear of after-life can never efface. Those who have lived in this country have seen him during the summer feeding on earthworms, caterpillars, berries, and fruits, and in winter presenting himself to receive from the hand of man that food which the frozen earth withholds. His habits, when he first ventures into the cottage to pick up the proffered crumbs, have been truly described by Thomson,-

"Then hopping o'er the floor,

Eyes all the smiling family askance, And pecks, and starts, and wonders where he is."

This bird seems at times to have indulged some whimsical fancies as to the situation of his nest. "A pair took up their abode in the parish church of Hampton, in Warwickshire, and affixed their nest to the church Bible as it lay on the reading-desk. The vicar would not allow the birds to be disturbed, and therefore supplied himself with another Bible, from which he read the lessons of the service." Mr. Thompson records a more extraordinary selection, made by one which had been frequently expelled from a bird- 
stuffing room when the window was kept open. Finding expulsion of no avail, the gentleman to whom the room belonged had recourse to a novel, and rather comical expedient. From his collection of stuffed Asiatic quadrupeds he selected some of the most fierce looking, and placed them at the open window, which they nearly filled, in hopes that their formidable aspect might deter the bird from entering; but the Redbreast was not to be so frightened, and went in as

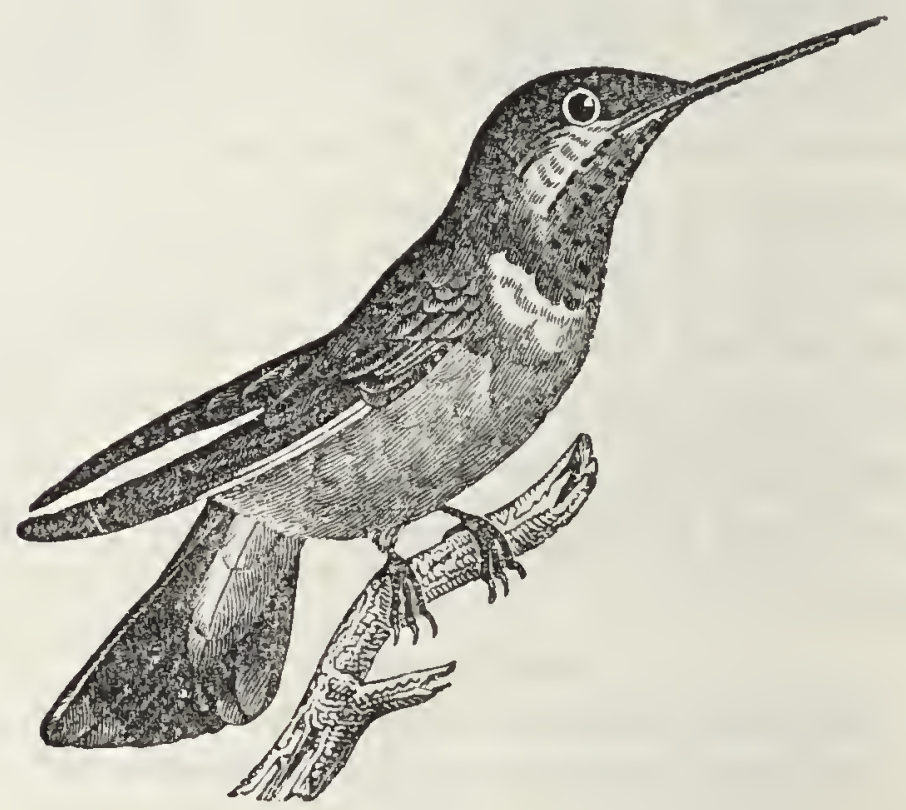

Fig. 173.-HuMMING-BIrd.

usual. It was at length allowed to have its own way, and, as if to mark its contempt of all such stratagems, the place chosen for the nest was the head of a Shark!

The perching birds remarkable for their slender bills have a name expressive of this peculiarity (Tenuirostres), and by many naturalists are regarded as a distinct tribe. To this group belong the Humuing-birds (Fig. 173), a family which includes some of the smallest and most 
beautiful of the whole feathered race, combining the richness of flowers and the brilliancy of gems. They take their name from the manner in which they hover over flowers, keeping up a humming noise by the vibration of their wings, the motion of which at such times is so rapid as to be scarcely visible. They are peculiar to America.

Tribe II.-Conical-billed Birds.-The Lark is not a good example of the structure by which the present group is distinguished; but it is the bird to which we listen with "ever new delight," when in early spring it pours down a flood of music on the earth, or when we hearken to the cheerful influence of its song as described by Milton,-

"To hear the Lark begin his flight, And singing startle the dull night, From his watch-tower in the skies, 'Till the dappled dawn doth rise; Then to come in spite of sorrow, And at my window bid good morrow."

The Lark is universally distributed over Europe, and verses addressed to this "messenger of morn" are everywhere current.

The common Starling (Fig. 174) is the representative of another family belonging to the same tribe. It is well known for its powers of imitating sounds; and from an early age has in some minds been associated with Sterne's well-known words,- "I cannot get out." It is a migratory species, and in some localities assembles not only by thousands, but even by millions. A large body of them, estimated at 150,000 or 200,000 , 
paid the zoologists of Dublin the compliment of taking up their quarters in a mass of thorn trees at the upper end of the Zoological Gardens in the Phœnix Park. Dr. Ball, the secretary of the society, described the Starlings, in 1845, as sleeping there every night from the end of October to about the end of March. They

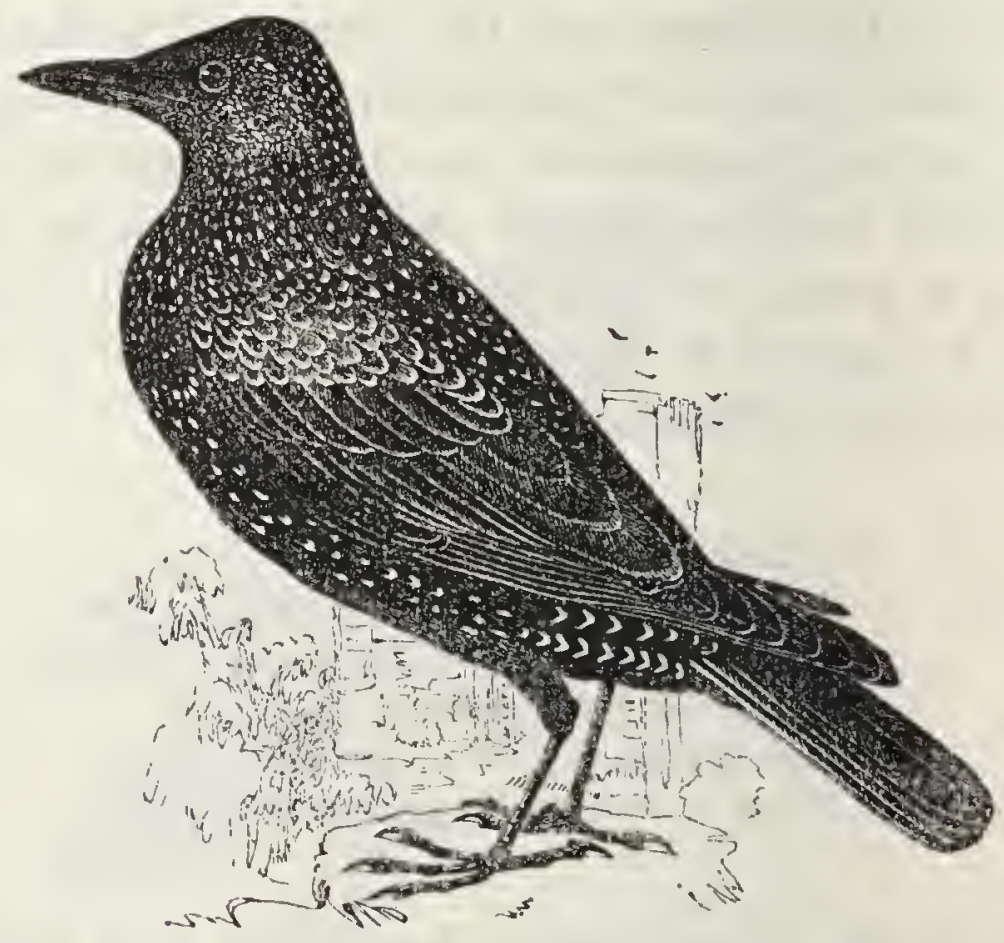

Fig. 174.-Starling.

have now (1860) abandoned the locality, in consequence of their having been disturbed.

This is, perhaps, the place where reference may be made to the Birds of Paradise (Fig. 175), which, according to eastern fable, lived upon dew and vapour, and carried on, without descending to earth, all the functions of life, even to the production of their eggs and young. They have justly been said, from the extreme beauty of their plumage, to hold the highest 
rank among the feathered glories of the creation. They are limited to New Guinea, or as it is frequently called, the country of the Papuas, and some of the adjacent islands of the South Pacific Ocean. The natives of these countries, when preparing and drying the skins, were in the habit of removing the feet of the bird. The sins in this state were sold to the Malays, carried into India, and thence conveyed into

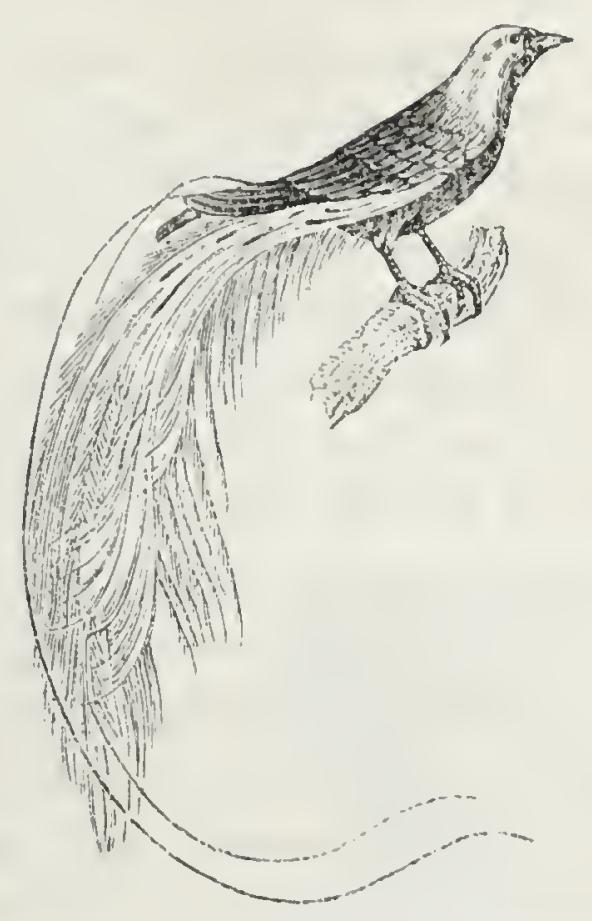

Fig. 175.-Bird of ParadisE. Europe. Here we have the origin of the superstitious ideas with which these birds were formerly associated, arising from their supposed want of legs. Linnaus, in applying to the best known species the term "footless," did so in reference to this legend; and it has also been embodied in the liarmonious lines of the poet,-

"The footless fowl of heaven that never Rest upon earth, but on the wing for ever, Hovering o'er flowers their fragrant food inhale,

Drink the descending dew upon its way, And sleep aloft while floating on the gale."

Southey's Curse of Kehuma.

The Rook may be regarded as the representative of another farnily, which includes the Raven, the Magpie, and the Jay. The Rook is a social bird, fond of living 
about the abodes of man, and even of building in the heart of crowded cities. But it is not with such haunts that its appearance is usually associated, but with timehonoured mansions, and more especially lofty trees, their chosen abodes during successive generations.

Washington Irving has written respecting these birds in his usual agreeable style. "They are," he says, "old established housekeepers, high-minded gentlefolk, that have had their hereditary abodes time out of mind;" and he goes on in the same amusing manner to describe, what "rather derogates from the grave and honourable character of these ancient gentlefolk, that during the architectural season, they are subject to great dissensions among themselves; that they make no scruple to defraud and plunder each other, and that sometimes the rookery is a scene of hideous brawl and commotion, in consequence of some delinquency of the kind."

It has been a question whether the Rook should be regarded by the farmer as a friend or an enemy; and it is the opinion of those who have most carefully examined the evidence on both sides that the continual benefit which Rooks confer, by the destruction of snails, worms, and insects, far more than compensates for any occasional injury they inflict. There are numerous insects that, in the caterpillar state, eat away the roots of grain or grass crops, while others in different stages make their attacks above ground and at a later season. The larvæ of the Cockchafer, of the Click Beetles, and of the Harrylonglegs, are all underground feeders; and sometimes when Rooks pull up grass and scatter it about, its roots have been already destroyed by the Grubs or Caterpillars for which the 
birds are searching. "A gentleman," says Mr. Jesse, "once showed me a field which had all the appearance of being scorched as if by a burning sun in dry hot weather. The turf peeled from the ground as if it had been cut with a turfing spade, and we then discovered that the roots of the grass had been eaten awaly by the larve of the Cockchafer, which were found in countless numbers at various depths in the soil." The Rooks, which evince remarkable quickness in detecting such spots, were in reality benefactors, not destroyer's. Numerous other examples of a similar kind might be brought forward.

There are some foreign birds which, in their general habits, approach to the present family. They are remarkable for the excrescence by which the beak is surmounted, and from which they derive their name of Hornbills (Fig. 176). This singular appendage is extremely light,

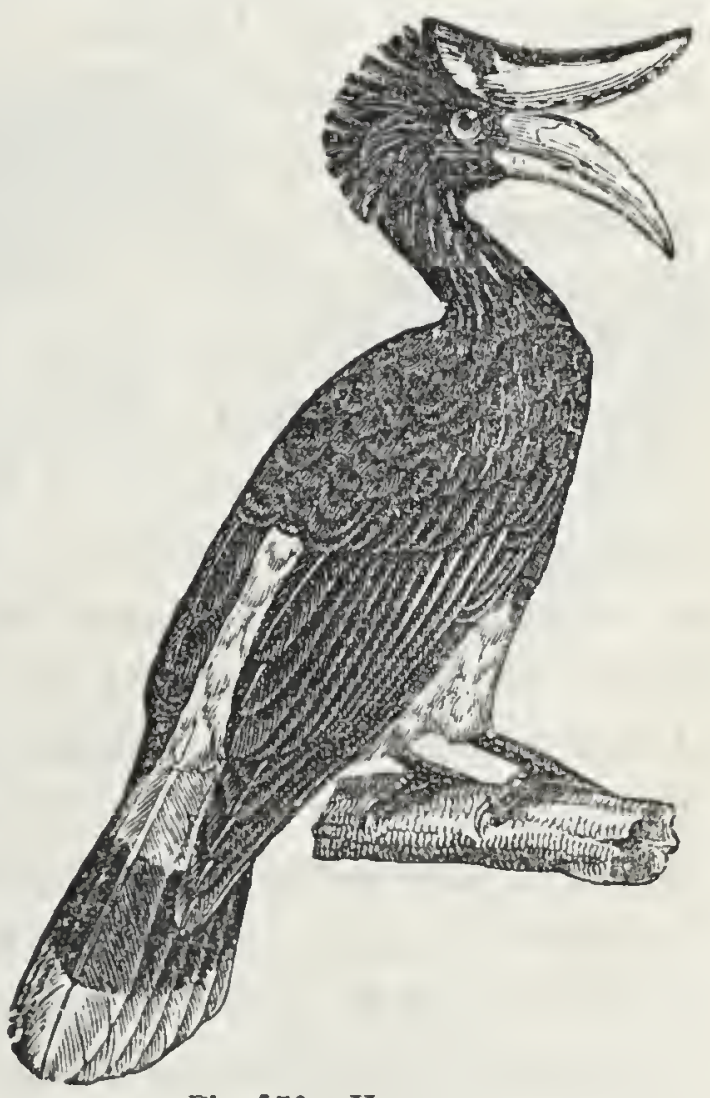

Fig. 176.-Hor.ville. consisting of numerous cells filled with air, which, in fact, penetrates with great ease every part of their skeleton. The Hornbills belong to the warm parts of Asia and Africa. 
Tribe III.-Chimbing Birds.-No better examples can be given of climbing birds than the Parrots, Cockatoos, and Macaws (Fig. 177) of tropical countries; those beautiful birds, many of which are domesticated in our houses, and which are uniformly one of the principal points of attraction in our Zoological Gardens. The formation of the foot and of the beak qualifies them in a pre-eminent degree to act as climbers.

One species of Parroquet is found on the western coast of Ceylon in astonishing multitudes. "At Chilaw," says Mr. Layard, "I have seen such vast flights of Parroquets coming to roost in the cocoa-nut trees which overhang the bazaar, that their noise drowned the babel of tongues bargaining for the evening provisions. Hearing of the swarms which resorted to this spot, I posted myself on a bridge some half mile distant, and attempted to count the flocks which came from a single direction to the eastward. About four o'clock in the afternoon straggling parties began to wend towards home, and in the course of half an hour the current fairly set in. But I soon found that I had no longer distinct flocks to count: it became one living, screaming stream. Some flew high in the air, till right above their homes, and dived abruptly downward with many evolutions, till on a level with the trees; others kept along the ground, and dashed close by my face with the rapidity of thought, their brilliant plumage shining with an exquisite lustre in the sunlight. I waited on the spot till the evening closed, when I could hear, though no longer distinguish, the birds fighting for their perches, and on firing a shot they rose with a noise like the 'rushing of a mighty 
wind,' but soon settled again, and such a din commenced as I shall never forget: the shrill screams of the birds, the fluttering of their innumerable wings, and the rustling of the leaves of the palm trees, were almost deafening, and I was glad at last to escape to the Government Rest House."-Tennent's Ceylon, vol. i., p. 172.

The Woodpeckers (Fig. 178) are examples of British birds belonging to the present group. Their food consists of insects in different states, for which they search under the bark of trees, digging into the wood of such as are decayed.

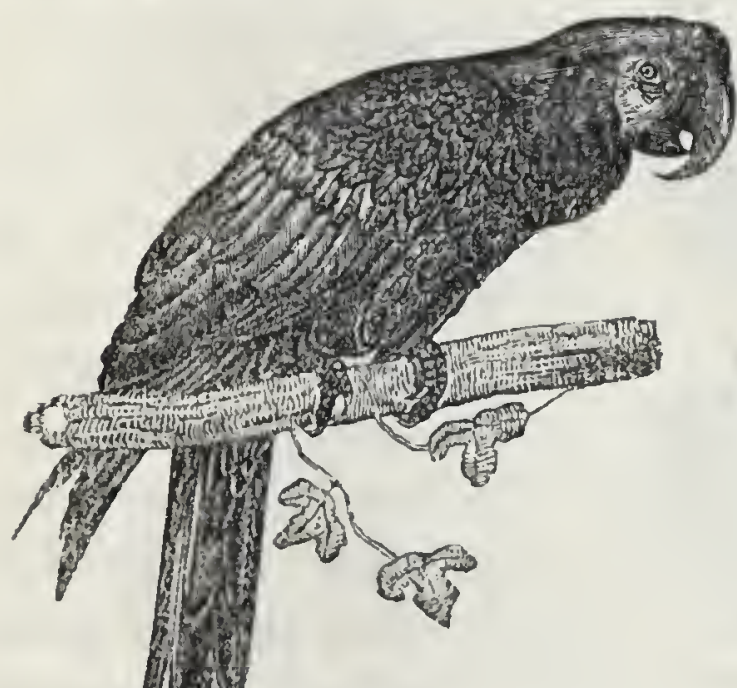

Fig. 177.-MACdW.

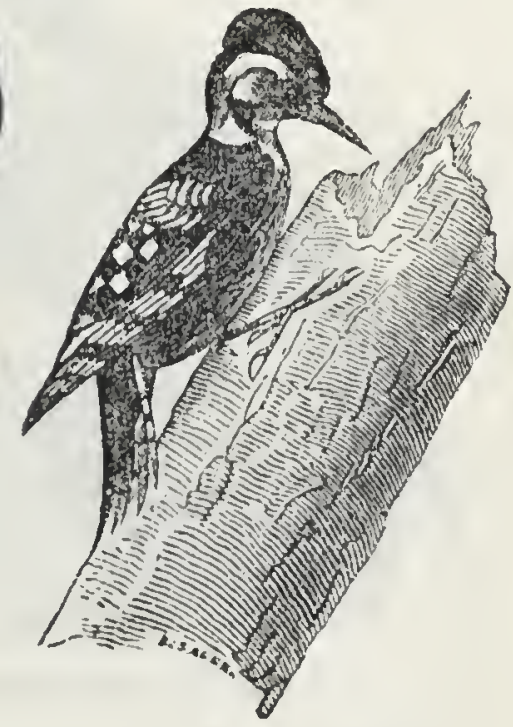

Fig. 178.-WOODPECKER.

The Wren, a favourite little bird, remarkable both for its diminutive size and its large family, must here be placed; also the Cuckoo, which builds no nest of its own, but drops its eggs into the nests of other birds, especially those of the Hedge Sparrow, the Pied Wagtail, and the Meadow Pipit. The young Cuckoo, soon after it has been hatched, throws out of the nest 
the other young birds, and also the eggs, remaining sole occupant, and securing to its own use the food which the old birds supply. Its joyous call is often referred to by the poets.

Tribe IV.-Gaping-Billed Birds.-The Kingfisher (Fig. 179) is without doubt superior to all other British

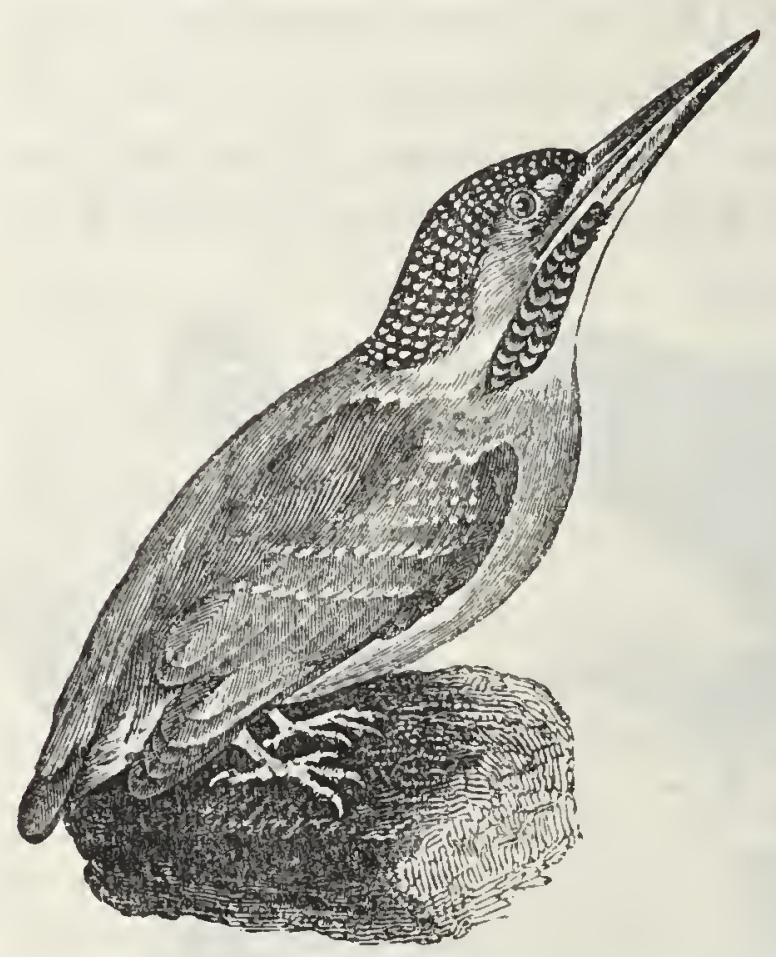

Fig. 179.-KINGFISHER.

birds in brilliancy of plumage, and is not surpassed by many of those belonging to tropical countries.

It was formerly believed that the Kingfisher, or as it was then termed, the Halcyon, hatched her eggs in a floating nest, and that during the time she was thus engaged the winds were at rest and the sea remained smooth and calm. This period was therefore called the Halcyon days, and is frequently referred to as such by the poets.

The Goat-suckers having been already mentioned (page 172), let us turn to the family of the Swallow.

"The Swallow" says Sir Humphry Davy, "is one of my favourite birds, and a rival of the Nightingale, for he cheers my sense of seeing as much as the other does my sense of hearing. He is the glad prophet of the year-the harbinger of the best season: he lives 
it life of enjoyment amongst the loveliest forms of nature; winter is unknown to him; and he leaves the green meadows of England in autumn for the palms of Africa."

The Swallow arrives in these comntries about the 10 th of April, and remains about six montlis. The House-martin appears a few days later than the Swallow. It is to this species the poet refers when he terms it

\section{"This guest of summer,}

The temple-haunting Martlet."

Its nests every one has seen fixed under the eaves of houses and the upper angles of windows.

The Sand-martin or Bank-martin is smaller in size than either of those mentioned, and is the earliest to arrive in these countries. The Swift most usually makes its appearance the first week in May, and departs in August.

An interesting fact has been established with regard to the House-martins - that they return to their old abodes. Mr. Thompson records an instance in the neighbourhood of Belfast, in which a pair found their nest occupied by a Sparrow, who seemed determined to keep possession. The Martins departed, returned with about twenty of their kindred, and built up the entrance to the nest, enclosing the offender within. Next morning the pair of Nartins commenced the construction of a new nest, against the side of their old one, and in it, undisturbed, reared their brood. After some time the proprietor of the cottage liad the curiosity to pull down both nests, and in that retained by the Sparrow found its remains, together with several eggrs. 


\section{Order III.-SCRAPING BIRDS.}

\section{RASORES.}

Trie present order includes several of those birds most commonly seen about the farm-yard, such as Cocks, Hens, Pea-fowl, and Turkeys; also the different kinds of Pigeons, Pheasants, Grouse, Quail, and Partridge. They are not in general adapted for rapid flight. They have the body bulky, the wings short,

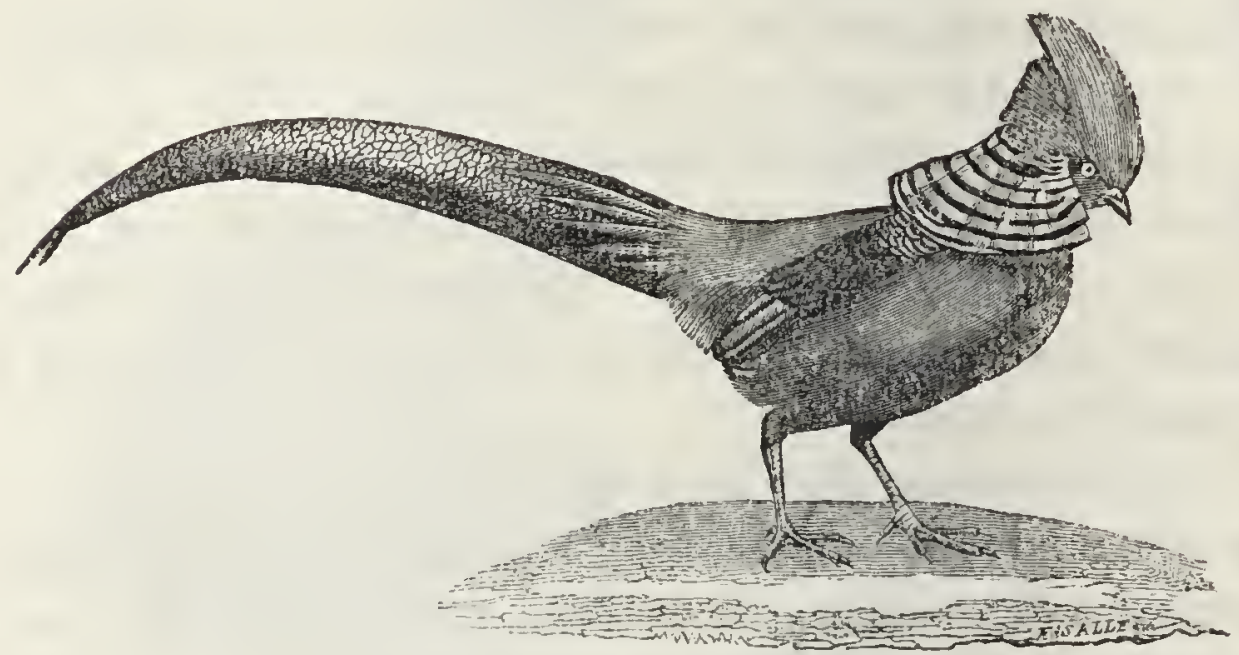

Fig. 180.-Golden Pheasant.

the legs robust, and the feet formed for walking;the feet are also employed in scratching the ground, and thus exposing to view the seeds or other food on which the birds subsist. This habit has given origin to the name by which the order is distinguished.

That division of Africa to which we give the name of Guinea is the native region of the Guinea-fowl (Fig. 181). The Peacock and Pheasant, together with our common domestic poultry, lave been brought from the warm parts of Asia and the neighbouring islands. 
The Doves constitute one well-marked family. The Ring-dove, or Wood-pigeon, is the Cushat of the poets: the Rock-dove is the species from which the varieties of the domestic Pigeon are derived. The

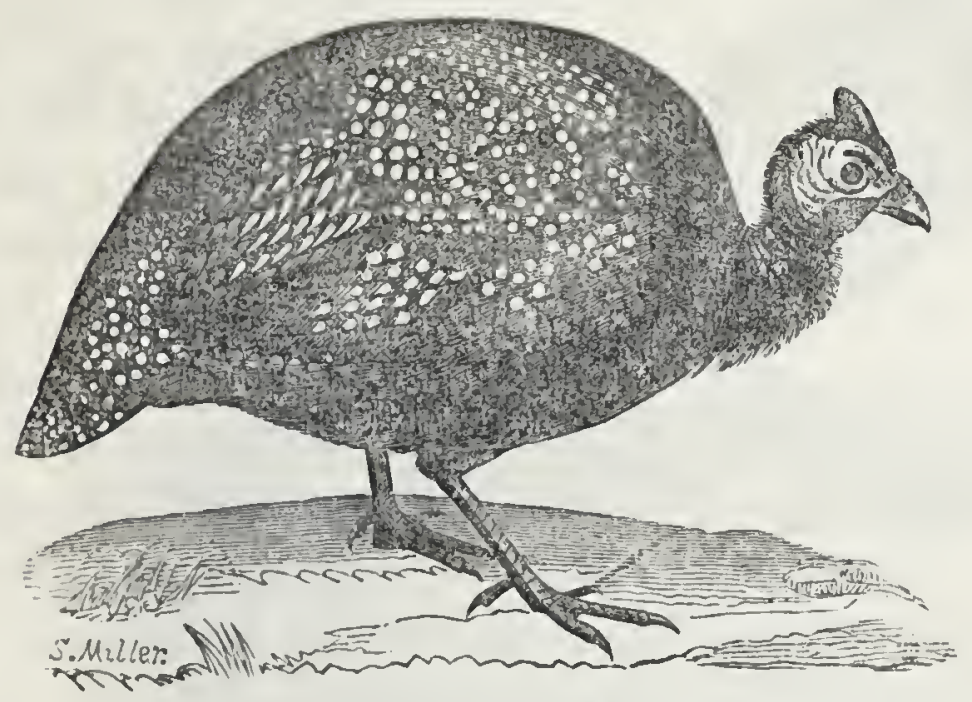

Fig. 1S1.-GUINEA-FOWL.

Carrier-pigeon, when perfectly trained, is remarkable for the speed with which its journey is accomplished, when no unfivourable circumstances, such as fog, mist, or a strong opposing wind, occur to retard its course. On one occasion a Carrier-pigeon flew from Rouen to Ghent, a distance of about 150 miles, in an. hour and a-half. On another, 23 Irish miles were accomplished in eleven minutes; or, in other words, at the rate of $125 \frac{1}{2}$ miles an hour.

The Golden Pheasant (Fig. 180) belongs to another family, and the Grouse and Partridge to a third. The Red or Common Grouse is found nowhere but in the British Isles.

The White Grouse, or the Ptarmigan, on the contrary (Fig. 182), inhabits both Europe and America. 
In these kingdoms it is found only on some of the liigh mountains of Scotland and the adjacent islands.

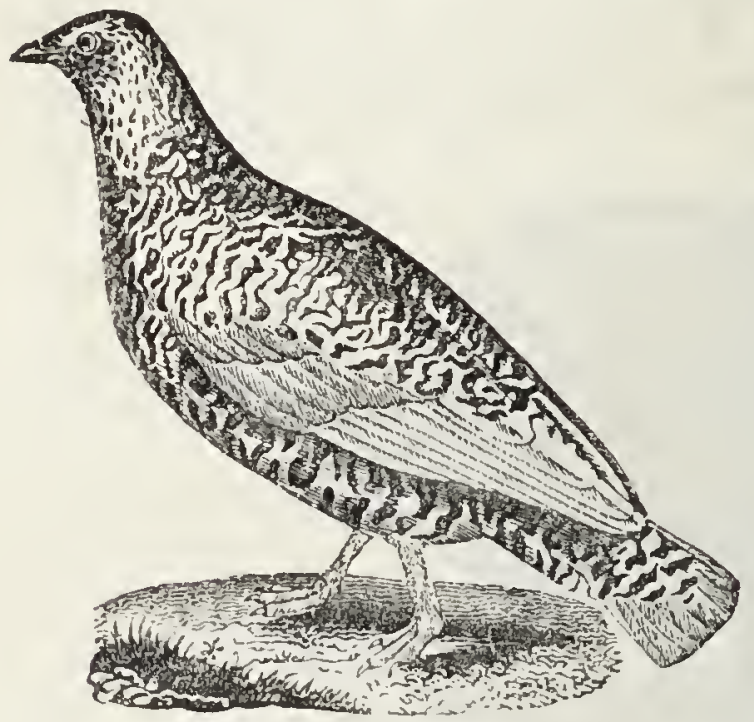

Fig. 182.-PTanmigar.

It is celebrated for the change of colour exhibited by the plumage at different seasons of the year. In summer this so closely resembles the surrounding rocks and lichens that the bird, when at rest, is scarcely to be distinguished from them; and in winter, it is like the snow-clad mountains.

Sir Walter Scott, therefore, attributes acute power's of vision to Malcolm Græme, when he says,-

"Train'd to the chase, his eagle eye The Ptarmigan in snow could spy."

\section{OrDER IV.-WADING BIRDS.}

\section{GRALLATORES.}

There are some birds whose legs are so long that the body seems as if mounted on a pair of stilts; and this peculiarity is that which is expressed by the scientific name for the present order-a Latin word-literally meaning those who walk on stilts. The lower part of the leg is naked; and from this circumstance, as well 
as from its length, is especially adapted for wading. Hence, birds of the present order are called "Waders."

But although this term is very correct as applied to some, it is altogether incorrect with regard to others; thus the Ostrich, which lives remote from the sea and from the banks of rivers, is included; and birds which, like the Plover, are not remarkable

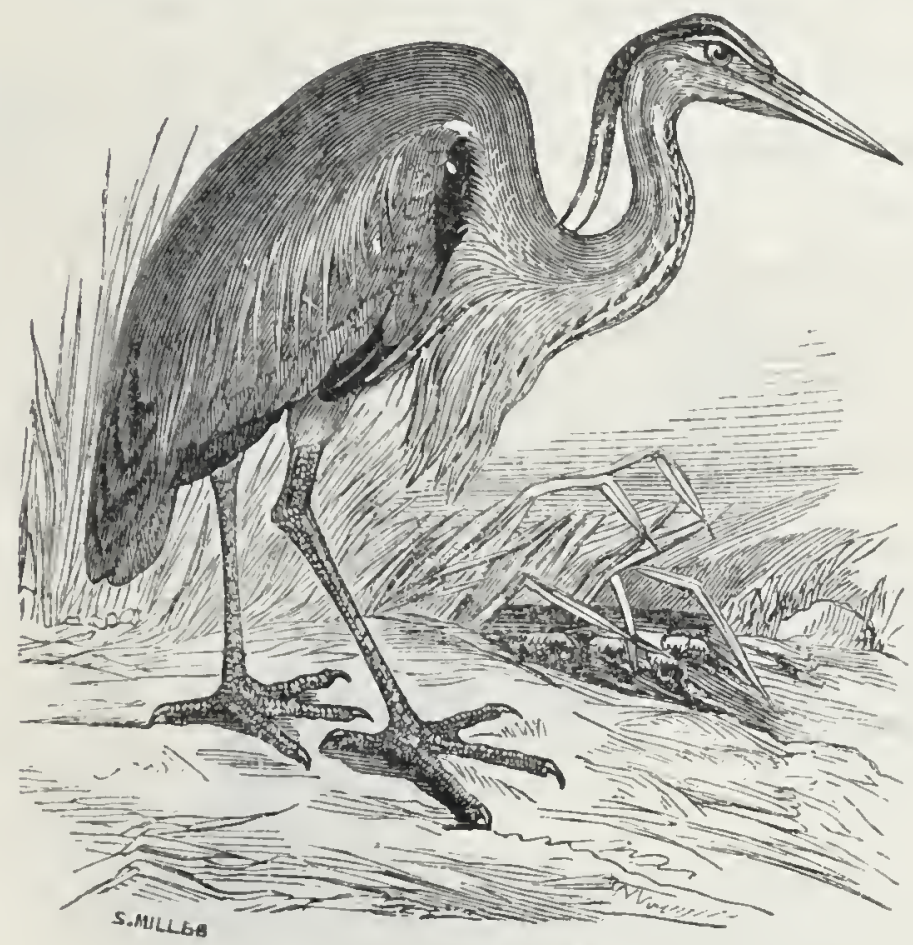

Fig. 183.-Common HERON.

for great length of leg, are also included. The fact is that here, as in other great groups, the characteristics must be sought in some which may be looked upon as the representatives of the order, and not be required in every individual that naturalists may place in the same assemblage.

The Common Heron (Fig. 183) is probably one of the best known birds belonging to the present order. Its motionless attitude, as it watches for its 
prey in the shallow of the river or the sea, cannot fail to have attracted attention, adding, as it not unfrequently does, to the effect of the scene. Nor less striking is its appearance on the wing: the long, outstretched legs acting as a balance to the weight of the head and neck. It is a strange sight to behold these birds collecting in spring at their building stations, occupying, like Rooks, the upper branches of high trees, and beginning once again the important business of hatching their eggs. They do not, however, always choose such situations, but occasionally select rocky cliffs near the coast.

In one family are comprised all the birds of the present order whose wings are not adapted for flying, as those of the Ostrich, the Rhea, or South American Ostrich, and the Cassowary* (Fig. 159). Here also is

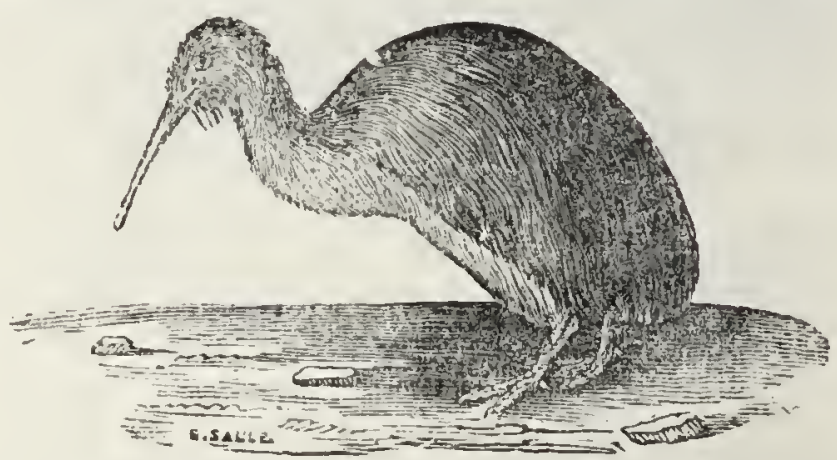

Fig. 184.-APTERYx.

placed the Apteryx of New Zealand (Fig. 184), a strange creature, without wings or tail; with strong legs, claws suited for digging, and actually used in forming the excavations in which this singular bird lays her eggs and hatches her young.

The bird called the Common Bittern (Fig. 185) is no

* Several authors rank them as an order under the name Cursores, a term meaning runners. 
longer a common bird in these countries, and is every year becoming more rare as waste lands are reclaimed. During the breeding season it utters a loud booming or bellowing noise, to which some of our poets have alluded, --

"But the Lark's shrill fife shall come

At the day-break from the fallow, And the Bittern sound his drum,

Booming from the sedgy shallow."-ScotT.

Living remote from liuman haunts, on the marsh, the bog, and the quagmire, it continues to this clay the emblem of desolation and solitude, as it was at the time when the Prophet proclaimed against Babylon the awful sentence: "I will also make it a possession for the Bittern, and pools of water; and I will sweep it with the besom of destruction, saith the Lord of Hosts."

The White Stork is another member of the same family that must not be passed by without men-

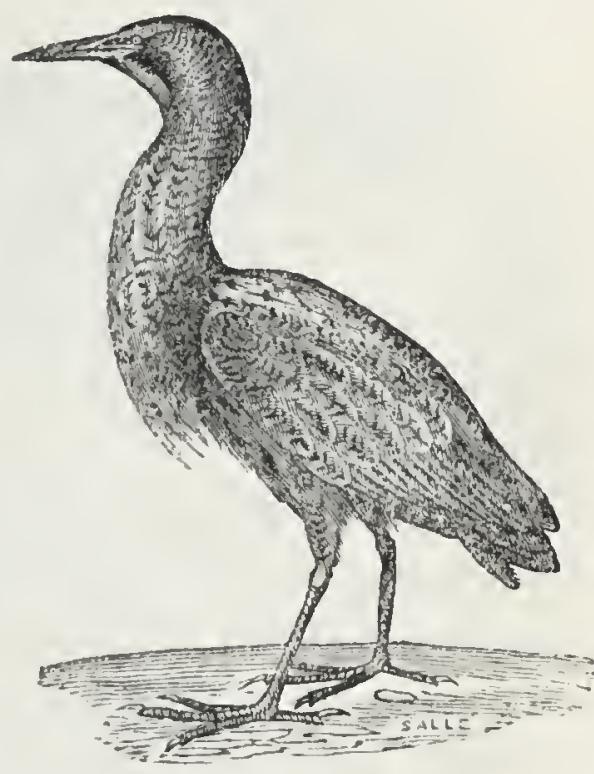

lig. 185.-BITTERN. tion. Those who have travelled in Holland, and other parts of the Continent, know the favourable light in which it is regarded, and the arrangements made for its accommodation and protection. The affection of the Stork for its young is one of the most remarkable traits in its character; it is only needful to refer to the female which, at the conflagration of Delft, after 
several unavailing attempts to remove her young, chose to remain and perish with them, rather than leave them to their fate. Among the ancient Egyptians, the Stork was regarded with reverence inferior only to that which was paid to the Sacred Ibisanother member of the present family.

The present order includes the Lapwing, the Curlew, the Snipe, the Wood-cock, the Sand-piper, the Rail, and many other species of British birds.

\section{ORder V.-SWIMMING BIRDS.}

\section{NATATORES.}

IN the birds of this order the bill is variously shaped. The legs short; often placed far behind, adlapted for swimming.

From the great extent of coast, and the varied character of the British Islands, the birds of the present order are so numerous as to constitute more than one-fourth of the entire of the native species. They are arranged in five families :-

I. The first of these comprises Geese, Swans, and Ducks. The domesticated Swan is, in these countries, the species most generally admired. Who is there who has not paused to gaze upon her arched neck, her graceful swimming movement, and her snowy plumage? It was no wonder that a classic writer referred to Black Swans in such a mamner as to imply his entire disbelief of their existence. Yet Black Swans are 
among those strange creatures that have been sent to us from New Holland. They are now distributed over the kingdom, wherever there are menageries of aquatic birds, and form a striking contrast to the snowy tint of the other species.

II. The Grebes and the Divers constitute the second family; and a glance at the annexed figure of the Great Northern Diver (Fig. 186) will convey a better idea of

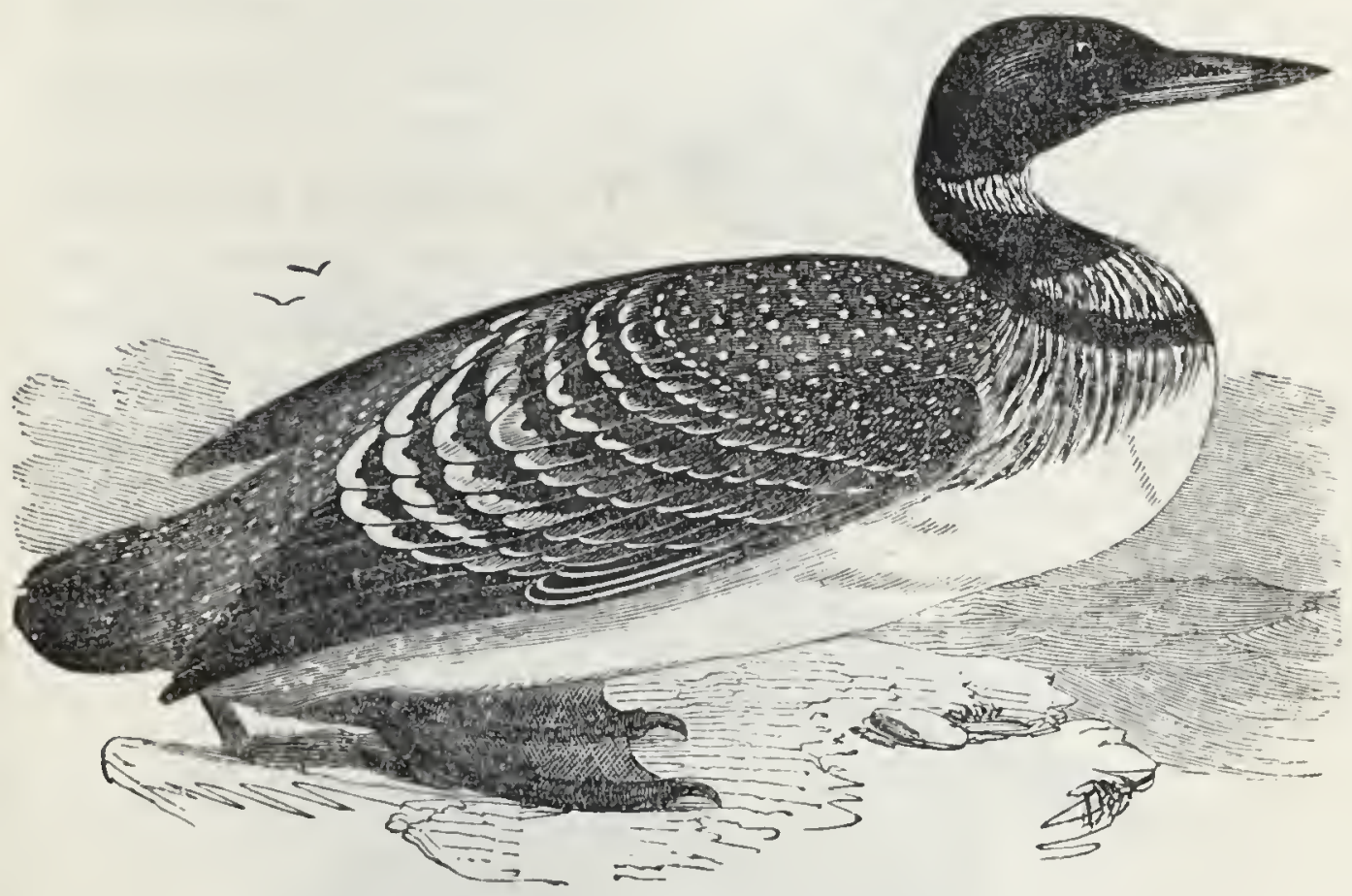

Fig. 186.-Great Northern Diver.

their aspect than any verbal description. The Divers, as their name implies, are remarkable for their diving powers, thus pursuing their prey and evading their enemies. The bird figured is a winter risitant, and belongs to a species which may be said to live upon the water, except during the time devoted to the rearing of the young.

III. In the third family is placed the Puffin, - a bird 
common around the coast during the summer months,

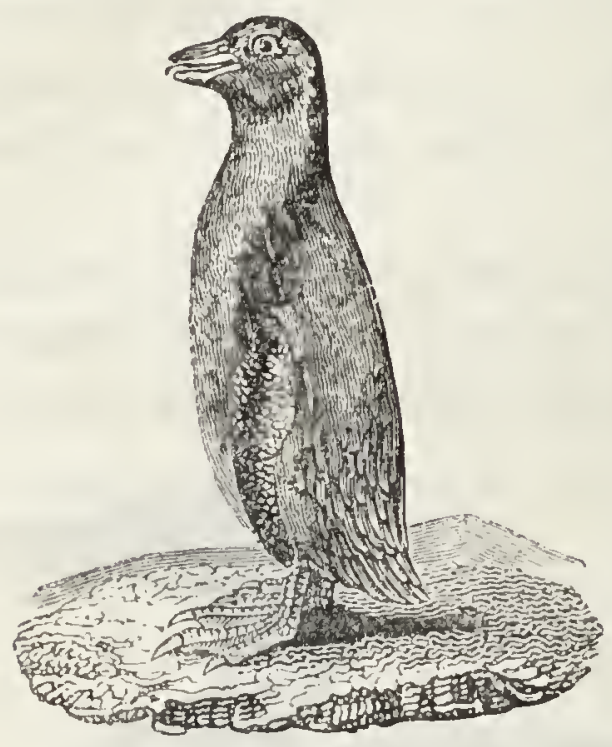

Fig. 187.-PENGEIN. and from the form of its bill, called "Sea-parrot" and "Coulter-neb." Here also must be arranged the Penguin, a native of the southern hemisphere (Fig. 187), whose singular plumage reminds us rather of the scales of a fish than the feathers of a bird. The wings, so useless for flight, are, however, most powerful as fins. When at sea and fishing, it comes to the surface, for the purpose of breathing, with such a spring, and dives

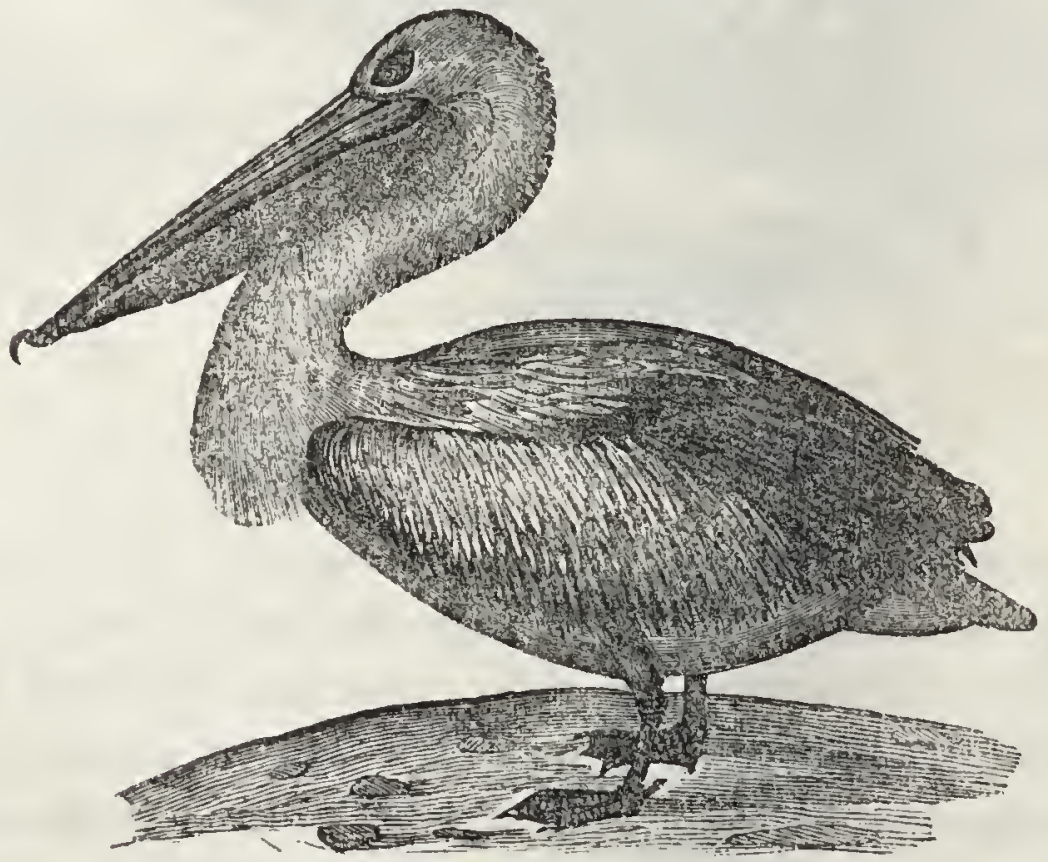

Fig. 188.-PELICAN.

again so instantaneously, that no one could at first sight be sure it was not a fish leaping for sport. 
which they ride upon the waves, and the animation which they give to the scene. Perhaps few common occurrences are more striking than what is termed a "Play of Gulls;" when the birds, having discovered a shoal of young fish, are swimming among them, hovering over them, uttering wild screams of joy, plunging down into the midst of the shoal, and gorging their prey with riotous delight.

In the building of the nests Gulls do not confine themselves to the rocks and cliffs of the sea-shore;

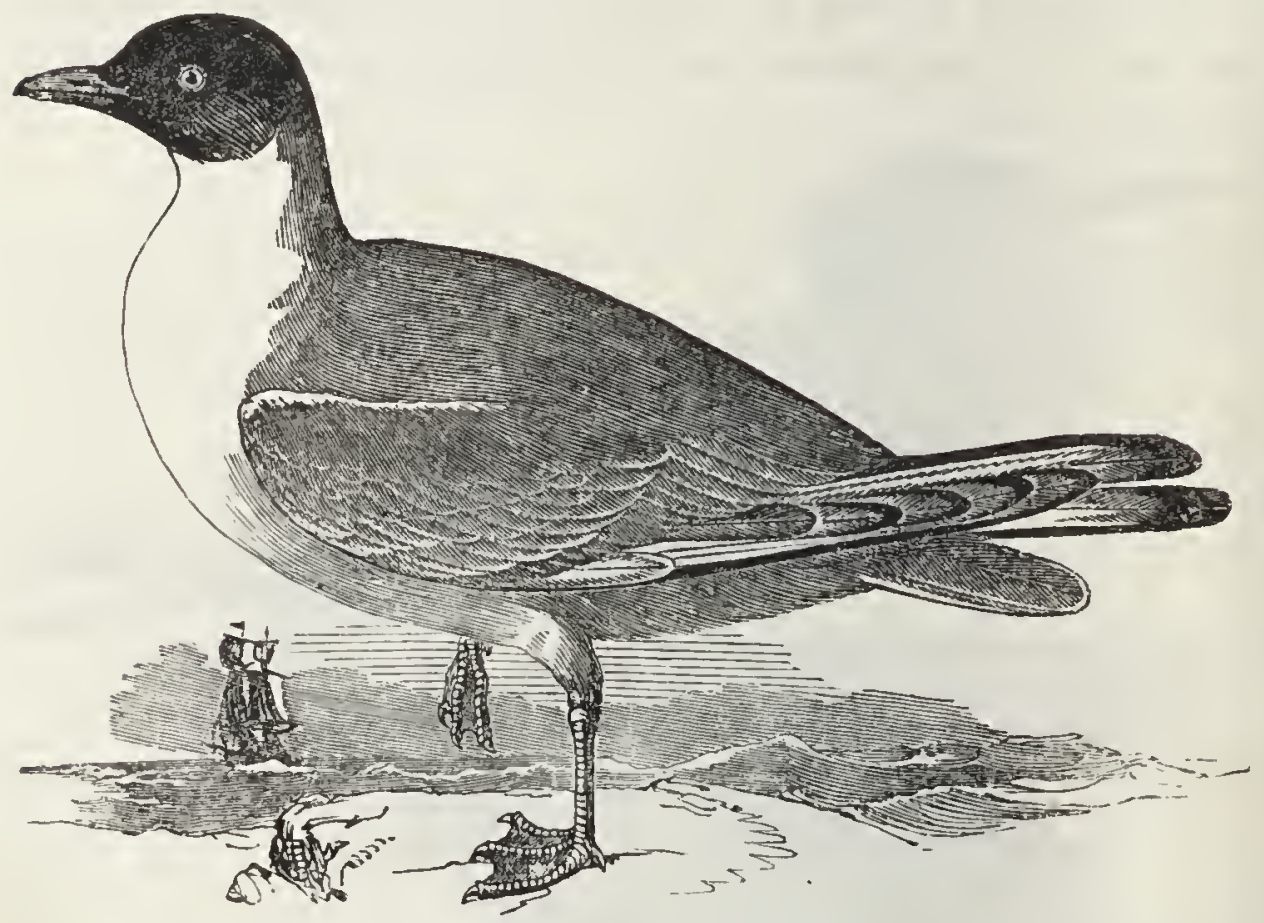

Fig. 190.-BLACK-HEADED GULL.

many retired inland localities are favourite places of resort. In Norfolk, at a distance of thirty miles from the sea, thousands of the Black-headed Gull (Fig. 190) annually take possession of an island of about thirty acres in extent, and build their nests. In the north of Ireland the Black-headed Gulls frequent the gravelly 
beach of a portion of Ram's Island in Lough Neagh for the same purpose.

Of the Petrels, the best known species is that which is the smallest of British web-footed birds, the Stormy Petrel. They crowd round vessels before and during stormy weather, partly for the sake, it is supposed, of shelter, and partly for that of food. Sailors regard them with superstitious feelings, and have long given them the name of "Mother Carey's Chickens," from some hag of the olden time, whose name would have been forgotten had it not thus been connected with those harmless little birds. Their dusky plumage, diminutive size, their labit of running upon the surface of the water, and the circumstances under which the mariner sees them, account very naturally for the feelings with which lie regards them.

\section{Class V.-MAMMALIA.}

\section{QUADRUPEDS, WHALES, BATS, MONKEYS, \&C.}

We have now reached the highest class in the animal kingdom: that class to which man himself belongs. Here only do we find organs for supplying to the young, during infancy, that fluid nutriment to which we give the name of milk. Every animal that suckles its young may, from that circumstance, be placed in the present class. They all have warm blood and breathe hy lungs. 
While scales form the characteristic covering of fishes, and feather's of birds, hair may be said to be that of the Mammalia. It is not, however, in all cases present, and it undergoes many changes in

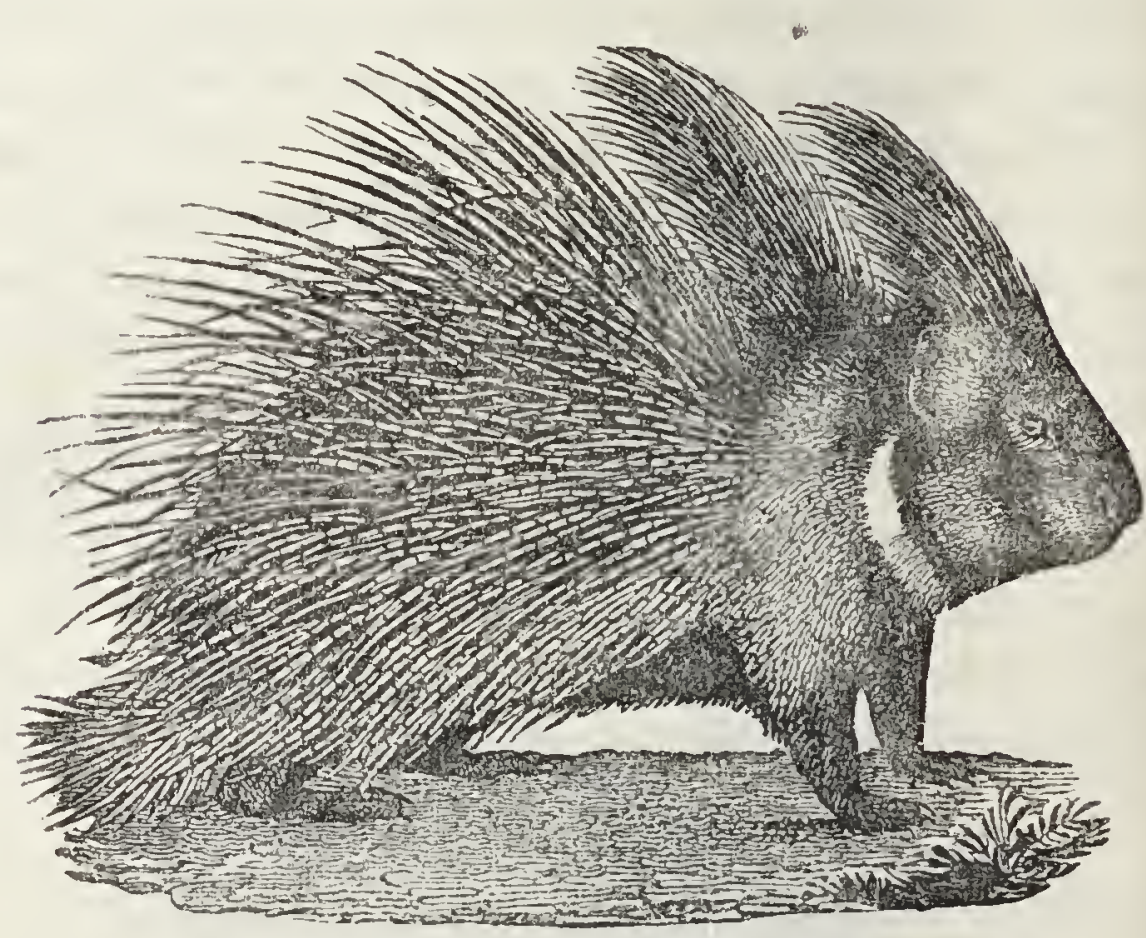

Fig. 191.-PORCDPINE.

its appearance. We term it wool upon the Sheep; the same material becomes spines upon the Hedgehog, and quills upon the Porcupine (Fig. 191). It is converted into bony plates in the defensive covering

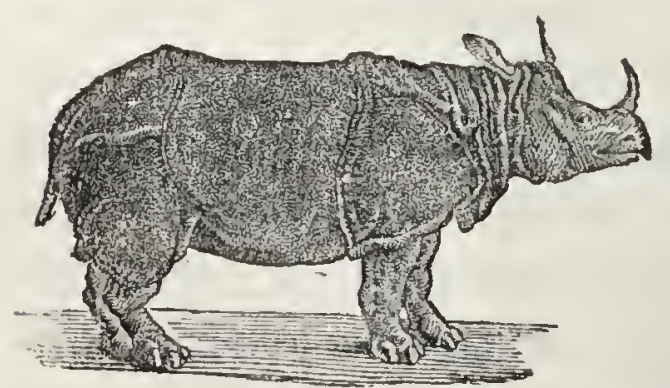

Fig. 192.-RHinoceros. of the Armadillo (Fig. 210); and in the weapon with which the nose of the Rhinoceros (Fig. 192 ) is armed, it presents the appearance of solid horn, adhering to the skin, not growing from the skull. 
The greater number of the animals of this class possess four feet, which are used in moving from place to place; but this structure, though general, is by no means universal. In the true Monkeys (Fig. 232) these parts are shaped like hands; in the Seals (Fig. 225) they are converted into paddles; in the Bats (Fig. 207) the bones which correspond to our fingers are so long as to form the framework of the wings; and in the Whales (Fig. 213) the hind limbs are wanting.

Great difference is found to prevail with regard to the number, form, and arrangement of the teeth. Further examination shows that the teeth vary in these particulars according as the food of the animal is to consist of soft flesh, or of horny-covered insects; of tender herbs, or of firm wood. And so entirely is one part of the bodily frame made to correspond with another, that it is perfectly possible, merely by looking at the teeth, to determine, with considerable certainty, the diet, the habits, and even the general structure of most of the Mammalia.

Hence the teeth, viewed in connection with the form of the extremities, furnish, so far as external characters are concerned, a sound basis for classification. As such they were regarded by Cuvier; and the principles he laid down have been adopted by succeeding naturalists, though differences have existed as to some of the details.

According to the following arrangement, the Mammalia are divided into twelve orders. They may be thus enumerated, commencing with thase which are lowest in the scale, and gradually ascending to man, 
who is the sole representative of the order to which he belongs.*

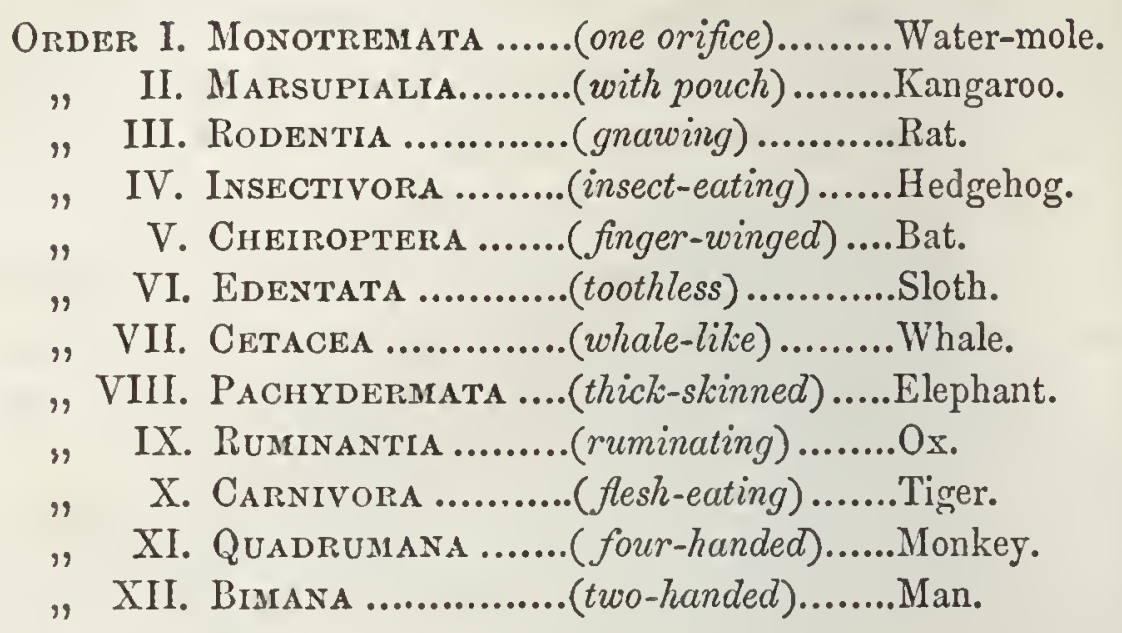

\section{ORDER I.-BEAKED QUADRUPEDS.}

\section{MONOTREMATA.}

THE present order contains but two genera, that of the Ornithorhyncus and of the Echidna. In point of structure they are inferior to all other Mammals, and approach in some respects to Birds, and in others to reptiles. They have no external ears, nor marsupial pouch.

* Professor Owen has proposed to arrange the several orders of Mammals under four sub-classes, in accordance with the principal variations of structure presented by the brain. The first of these groups includes Man alone. In the second are placed the Monkeys, Carnivora, Hoofed Mammals, and Whales. The third sub-class contains the four orders Edentata, Bats, Insectivora, and Rodentia. The last and lowest sub-class has in it but two orders, the Marsupials and Monotremes. 
The Ornithorhyncus, or duck-billed Platypus (Fig. 193) is about eighteen inches long, and is called by the natives of Australia the Water-mole. It frequents tranquil waters, seeking its food among aquatic

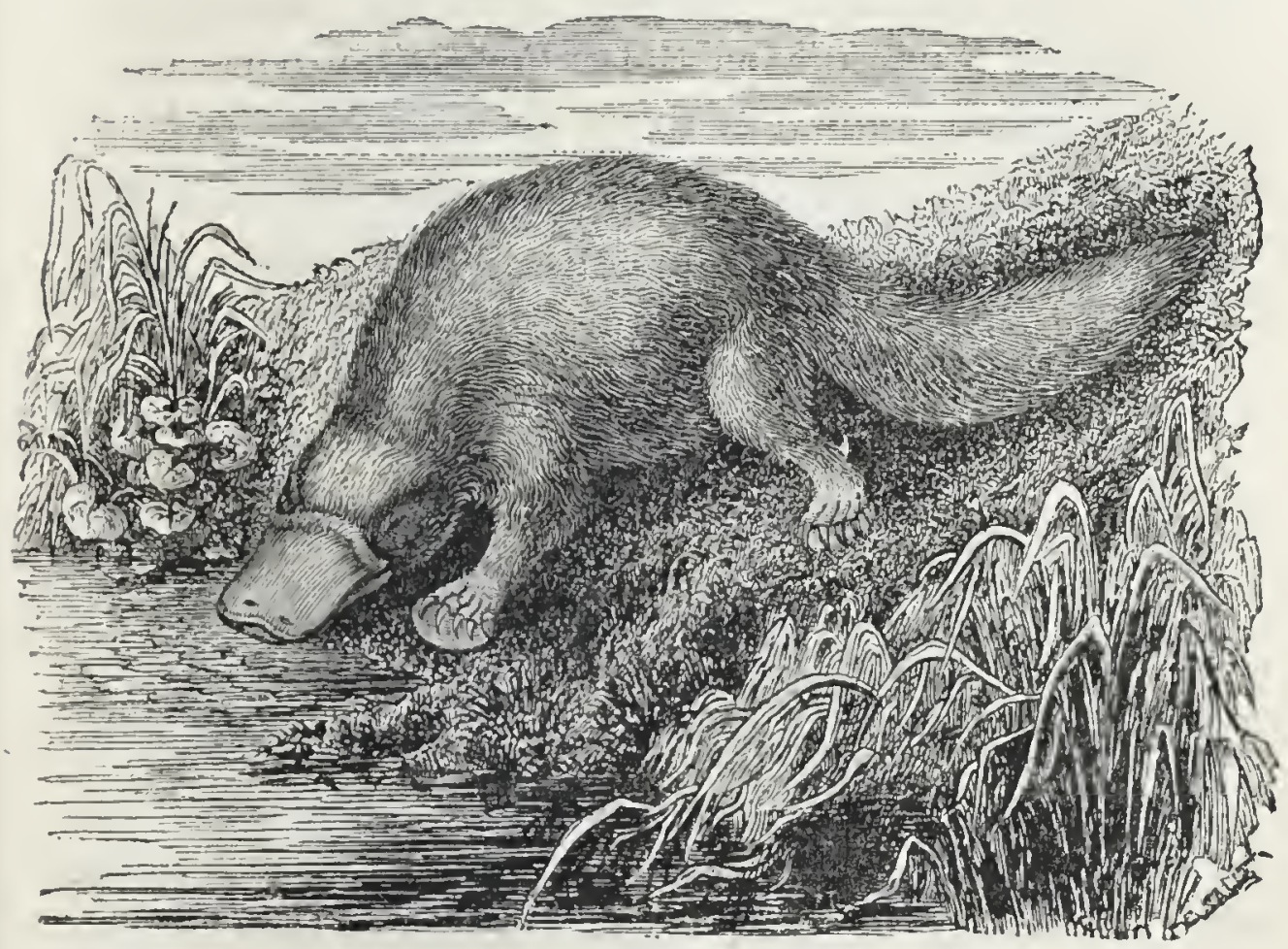

Fig. 193.-ORNITHORHYNCUS.

plants, and burrowing in the steep and shaded banks. The motion of its mandibles, when procuring food, is similar to that of a Duck under the same circumstances.

When the first specimens of this creature arrived in Europe, and naturalists saw the body of a quadruped joined to the bill of a bird, they naturally suspected that the union was an artificial one. The real animal was in fact more wonderful than that which any deuler in "strange beasts" would have ventured to make up.

The Echidna bears a general resemblance to the 
Hedgehog; but the spines with which it is covered are much stouter. The beak-like slender jaws are entirely destitute of teeth, and the tongue is of great length, like that of the true Ant-eaters. It has strong claws, well fitted for digging, lives on insects, and is known in Australia as the "Porcupine Ant-eater." The full-grown animal is about seventeen inches long: it avoids, like many other animals, the glare of day, and may, in its habits, be described as nocturnal.

\section{Order II.-MARSUPIAL, OR POUCHED ANIMALS.}

\section{MARSUPIALIA.}

Tre present order derives its scientific name from the circumstance of the female, in most instances, being furnished with a peculiar pouch, ${ }^{*}$ in which the young are received and nourished, and to which they retreat for safety. 'The Kangaroos and Opossums are familiar examples.

The Kangaroos of Australia are vegetable-feeding animals, which browse upon herbage like oxen, and in some cases chew the cud as they do. Some of them, when in their common erect position (Fig 194), are nearly as tall as a man; others, both in size and general appearance, resemble the common Hare. On one occasion, at the Surrey Zoological Gardens, I noticed on the abdomen of a large bluish-gray coloured Kangaroo two appendages, which were, in fact, the fore-

* Latin Marsupium, a pouch or bag. 
feet of the young one appearing outside of the pouch. In another moment the head peeped out, and the young creature began gazing around. The mother then bent down, and with great tenderness began

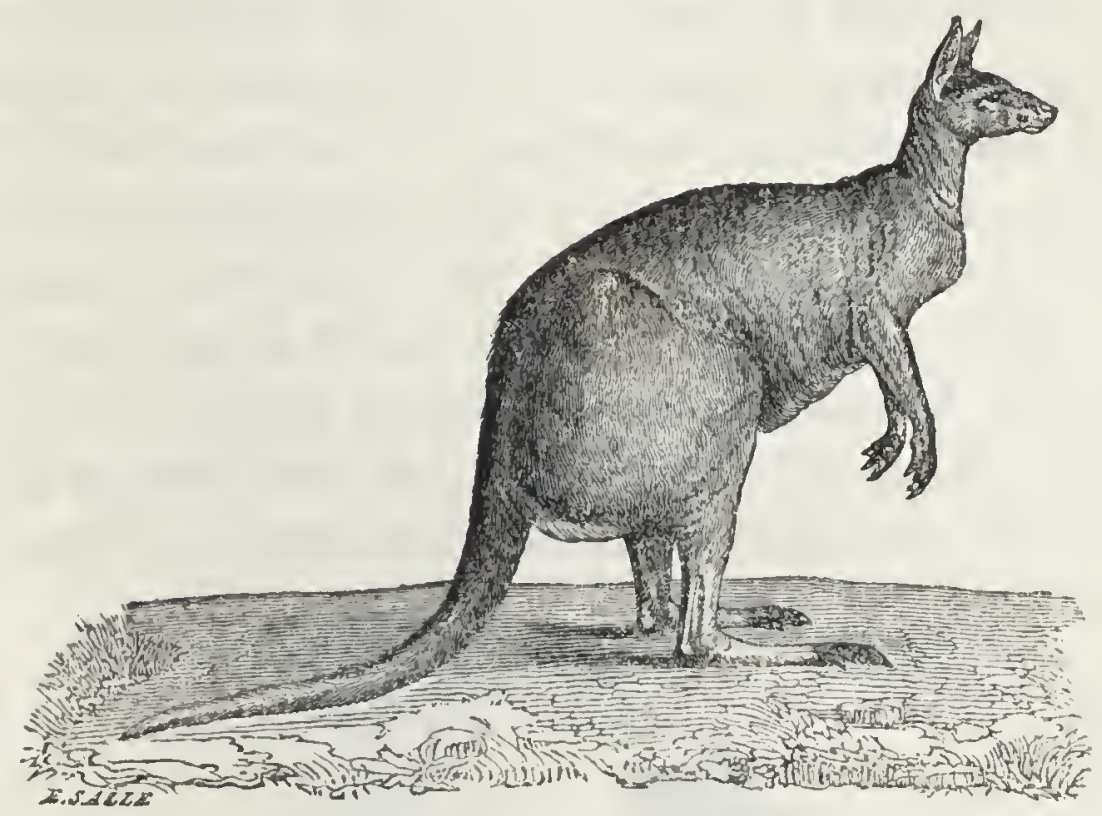

Fig. 194.-Kungaroo.

licking its face and head. These endearments being finished, the young one came out and was amusing itself on the ground, when, alarmed by a sudden noise, it jumped into the pouch and was seen no more!

With the exception of two genera, the whole of the existing marsupial animals belong to Australia, Tasmania, and New Guinea. The grazing and browsing Kangaroos are rarely seen abroad in the day-time, save in dark, rainy weather.

The following remarks of Professor Owen will be read with interest, pointing out as they do how admirably the modification of structure by which the Kangaroo is distinguished, is adapted to the peculiar conditions of the climate of Australia :- 
"The adventurous and much-enduring explorers of that continent bear uniform testimony to the want of water as the chief cause of their sufferings and danger. During the dry season the rivers are converted into pools, 'few and far between:' and the drought is sometimes continued so long as to dry up these. An ordinary non-marsupial quadruped, such as the wild Cat or Fox, having deposited her young in the nest or burrow, would, in such a climate, at the droughtiest period of her existence, be compelled to travel a hundred, perhaps two hundred miles, in order to quench her thirst. Before she could return her blind and helpless litter would have perished. By the marsupial modification

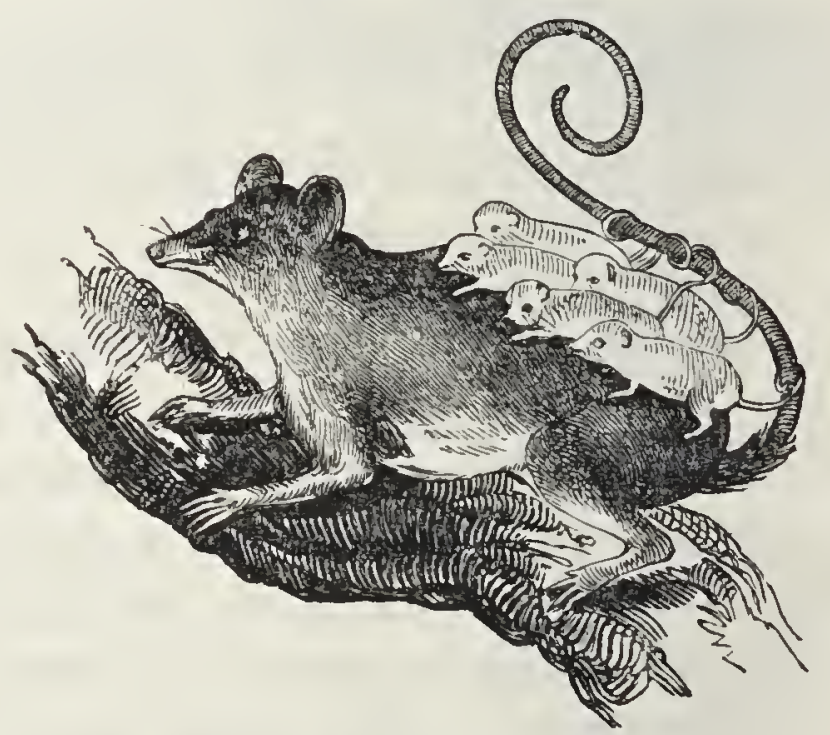

Fig. 195.-Merian's Opozsom.

the mother is enabled to carry her offspring with her in the long migrations necessitated by the scarcity of water."

It must not be supposed that all marsupial animals are harmless. The Thylacinus, or Pouched Wolf of Tasmania, is an instance of the reverse. It bears some 
resemblance to the Wolf, and at night does much injury to the sheep of the colonists.

The Opossums are peculiar to America. In South America they are especially numerous; most of them are but little larger than the common Rat; a few approach in size to the domestic Cat. The feet are shaped like hands. The food consists chiefly of insects; but small reptiles, as well as birds and their eggs, are preyed on by the larger species. Some of them, like the one represented in the annexed figure (Fig. 195), have no pouch, and the young manage to keep their places upon the back of the mother, by twisting their long tails round the tail of their parent.

\section{ORDER III.-GNAWING ANIMALS.}

\section{RODENTIA.}

THE preceding order's are composed entirely of animals belonging to foreign countries. The present is well represented among our native quadrupeds, as the British species furnish examples of some of the most important families. The characteristics of the group are so well developed in the Rat and the Mouse, that the family to which they belong is regarded as the type or representative of the order.

If all the known species of Mammalia were added together, it would be found that considerably more than one-half of the entire number would be animals belonging to the present order. 
The most striking characteristic of the gnawing animals is the structure of the teeth. The molar or grinding teeth have ridges of enamel variously

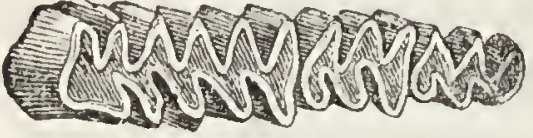

Fig. 196.-Molar Teeth OF Yole.

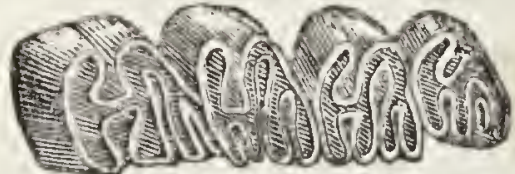

Fig. 197.-Molar Teeth of Beaver.

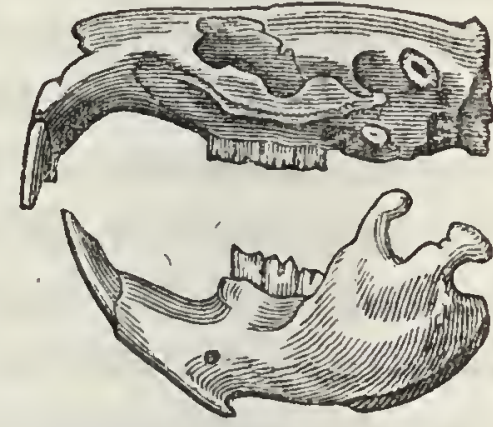

Fig. 193.-STrULL of a GNaWING ANIMAL.

arranged (Figs. 196, 197), which keep up the inequality of surface, as they wear less rapidly than the other portions. The incisor or cutting teeth, with their chisel-shaped edges, are, however, more remarkable. These are the teeth which we observe in the front part of the mouth of the Rat or the Rabbit, and which are shown in the annexed figure (Fig. 198). They continue growing during the entire life of the animal. New matter is ever added at the base, the enamel or hard coating of the teeth is deposited on the outer edge, the softer or inner portions of the teeth wear away, and thus the bevelled or sloping edge of these most efficient tools is invariably preserved.

Knowing these facts, we cannot examine the teeth of the Squirrel or the Mouse, without being struck with the amount of design they exhibit, the care for the wants of the animal they manifest, and the perfection in which the continual growth compensates for the constant wearing away.

The animals of this order are distributed over all 
continents. They are mostly small in size, and endowed with wonderful powers of increase. They feed more or less on vegetables, and furnish a vast supply of

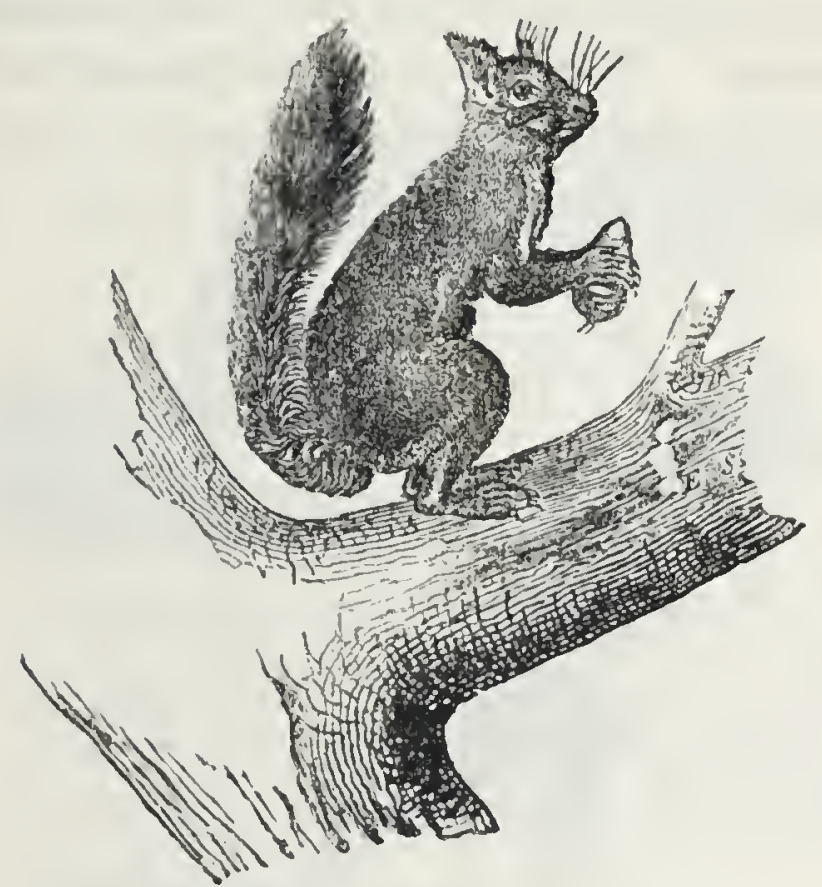

Hig. 199.-SQUIRREL.

food to carnivorous beasts and birds, and also to man himself.

We have in this order several examples of animals which hybernate, or pass the winter in a greater or less

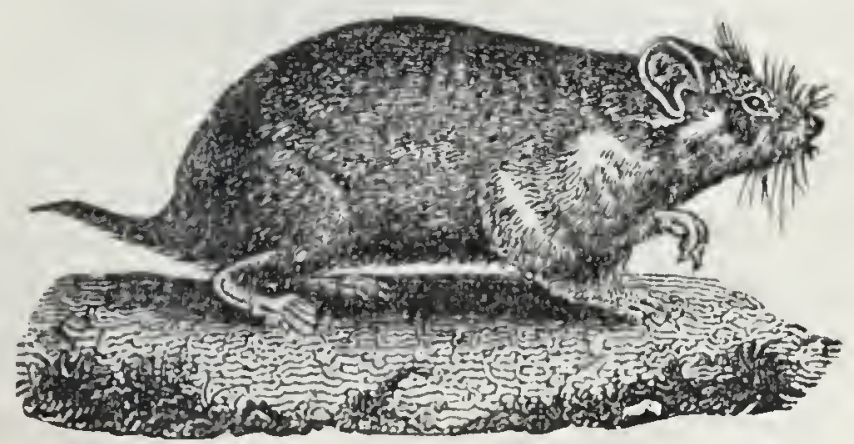

Fig. 2U0. - Ha BISTER.

complete state of torpidity. Thus, the Marmot of the Alps and Pyrenees dozes away the winter, until the 
sunshine and the showers of April rouse it from slumber. The Hamster of the North of Europe (Fig. 200) lays up in its winter quarters a plentiful store of grain, which it conveys from the fields in its capacious cheek pouches. The provident instincts of the Squirrel (Fig. 199) and the Dormouse need only be referred to. The Jerboa, or Jumping Rat of Egypt (Fig 201),

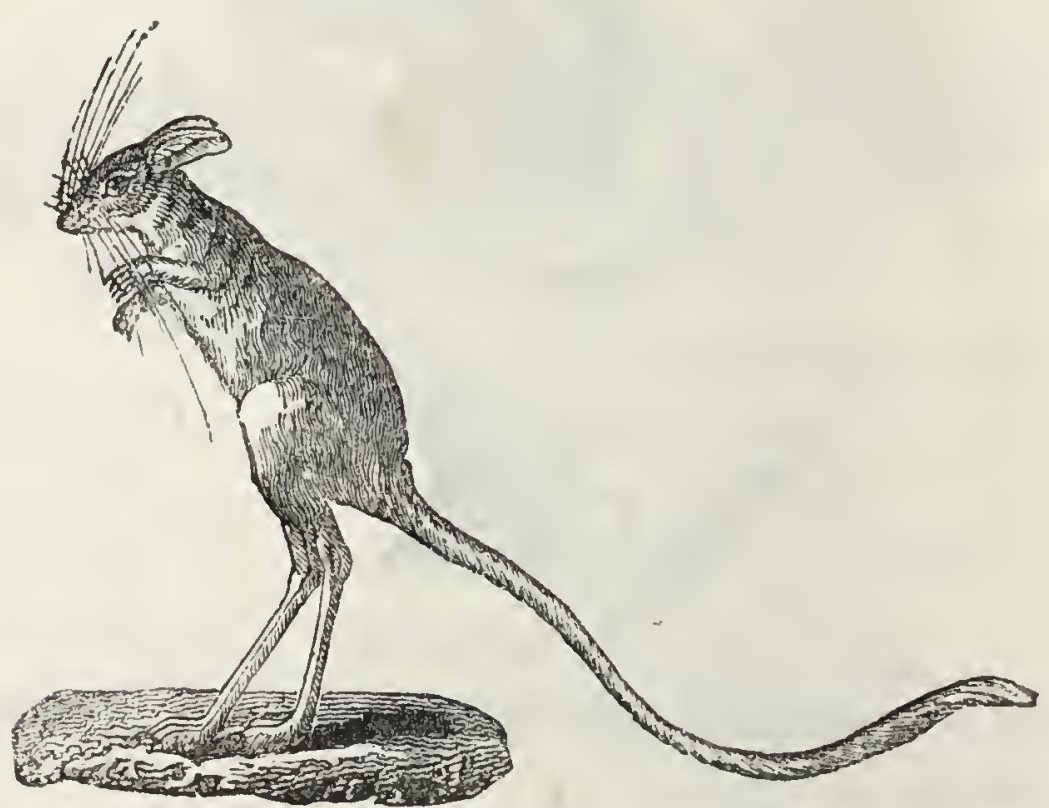

Fig. 201.-JERBOA.

although it does not hybernate, establishes stores of grain; and thus "provideth her meat in the summer, and gathereth her food in the harvest."

The Rodents of England and Ireland, though the countries are so near, are not alike. The pretty little Dormouse is not found in Ireland. The Irish Hare is a different species from the common Hare of England, and the Voles (Fig. 202), (genus Arvicola) of which there are three English species, are altogether unknown in Ireland.

The Beaver (Fig. 203) is remarkable as exhibiting 
one of the few examples known among quadrupeds, of an animal constructing its own habitation of materials selected for the purpose, brought from a distance, and cemented together into a regular structure. It is not surprising that a creature possessed of such powers

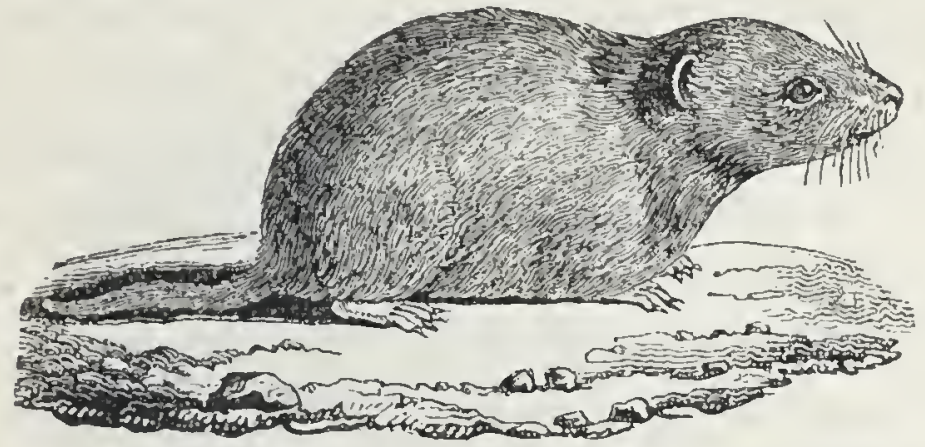

Fig. 202.-Field Vole, or Short-tailed Field Mouse.

should have had them represented in exaggerated colours; that it should have been described as making use of its broad tail both as a sledge and as a trowel;

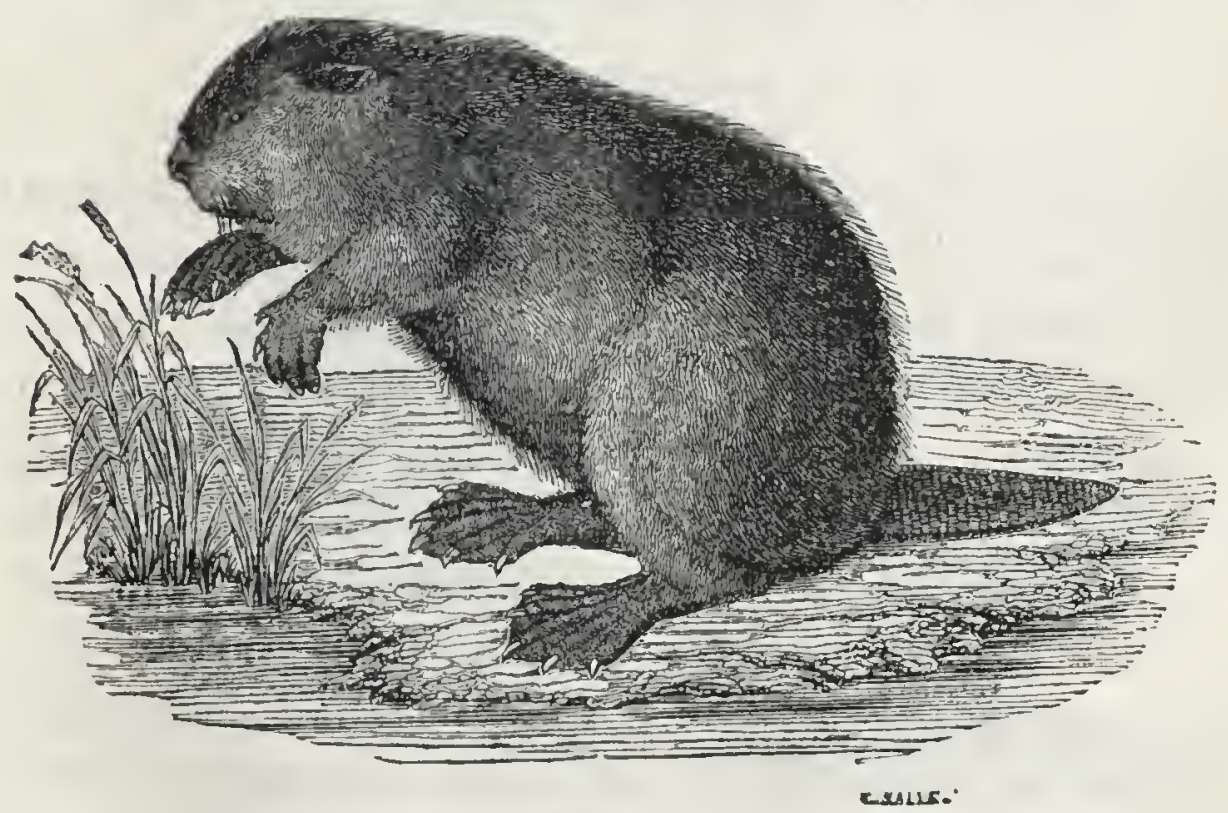

Fig. 203.-BEAVER.

of being able to drive stakes, the thickness of a man's leg, three or four feet into the ground; and as enjoying 
the advantages of social policy and a settled system of government. A better knowledge of the habits of the American Beaver has dissipated these idle tales, and shown that its building powers have been much exaggerated. Still the labours of the animal cannot but excite our wonder; nor can we behold, without a lively interest, the scene presented by its populous village. The flesh is regarded as a luxury by the Indians, and the fur is so valuable that it constitutes an important branch of commerce. A different species of Bearer. was at one time a native of Britain, and is still found on the banks of the Rhone, the Danube, and other rivers of Europe.

\section{ORdER IV.-INSECT-EATING ANIMALS.}

\section{INSECTIVORA.}

ThE animals belonging to the present order have teeth which are raised into pointed and conical summits. The Shrew, or as it is popularly called the "Shrew Mouse" (Fig. 204), the Hedgehog (Fig. 205), and the

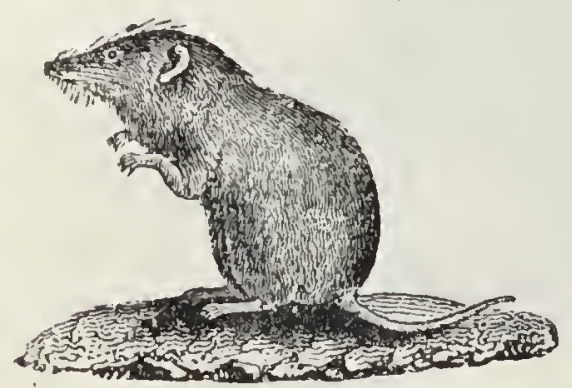

Fig. 204.-SHREW. Mole (Fig. 206) are examples of British species of this order, representing different families.

The common Hedgehog (Fig. 205) is widely distributed over Europe, but is not found in America. Its peculiar mode of defence, by rolling itself up and presenting only its prickly 
covering to all intruders, is to it a safeguard more effectual than strength or swiftness.

The Mole is not found in any part of Ireland. It has no external ears, and the eyes are so extremely minute, that in popular language it is always spoken of

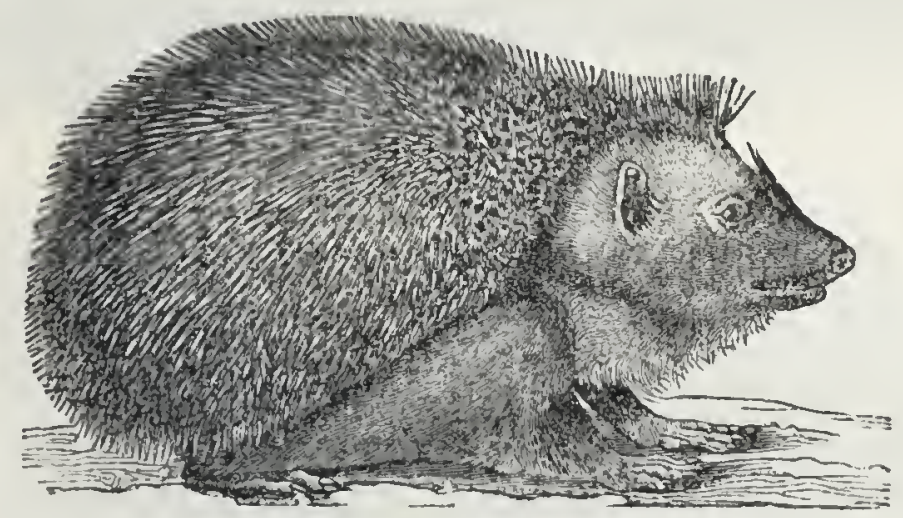

Fig. 205.-HEDGEHOG.

as "blind." The broad forefeet, with the palms turned outwards, and so admirably adapted for digging, are the most striking characteristic. The food consists of insects and worms; and as the animal does not become dormant during the winter, the necessity of exertion to obtain the needful supply of food is continual.

The figure is copied from Professor Bell's British Quadrupecls, by the kind permission of the learned author. I wish that the brief extracts here given from that work could induce such of my readers as have the opportunity, to refer to it for fuller information. The Mole, "blind, awkward, and shapeless," condemned to a life of toil in subterranean darkness, seems to the superficial observer an object of pity. To the naturalist it affords another proof " of the wisdom and beneficence of the Creator, which can render a life so apparently 
incompatible with comfort, in reality one of almost incessant enjoyment."

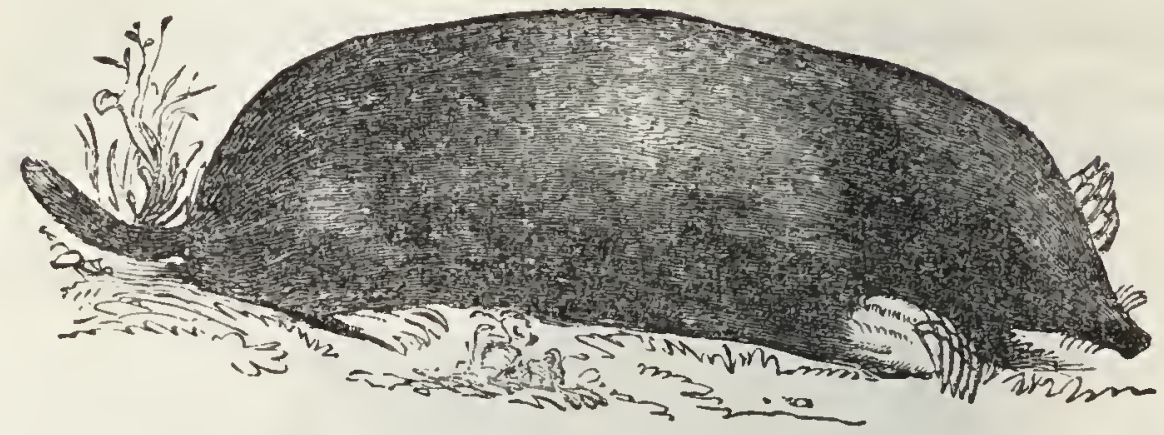

Fig. 206.-MoLE.

"Its feeding and its habitation, its wanderings and its repose, its winter retreat, and the nest in which its young are brought forth and nourished, are all so many calls for the most laborious and enduring toil ; but on the other hand, that toil is so amply provided for in the whole structure of the animal, so exactly balanced by the strength and conformation of its limbs, that it cannot be considered as exceeding the healthful, and even pleasurable exercise of its natural powers.

The Insectivora do not exist in South America or Australia; their office in these countries being fulfilled by the marsupial animals; but true Insectivora abound in all the other continents and their islands.

\section{Order V.-BATS.}

CHEIROPTERA.

"The Bat, that with hook'd and leathery wings

Clung to the cave-roof."-Southex.

When we see the Bat flitting about after its insect prey in the dusk of the summer evening, we at once 
recognize it as an insectivorous animal, adapted for capturing its food in the air instead of on the earth. We then are naturally led to inquire by what means is this effected? what is the mechanism by which the power of flight is given to the Bat? It is furnished with wings. Do they resemble those of the bird? They are altogether unlike, differing not only in the absence of feathers, but in their entire structure. In

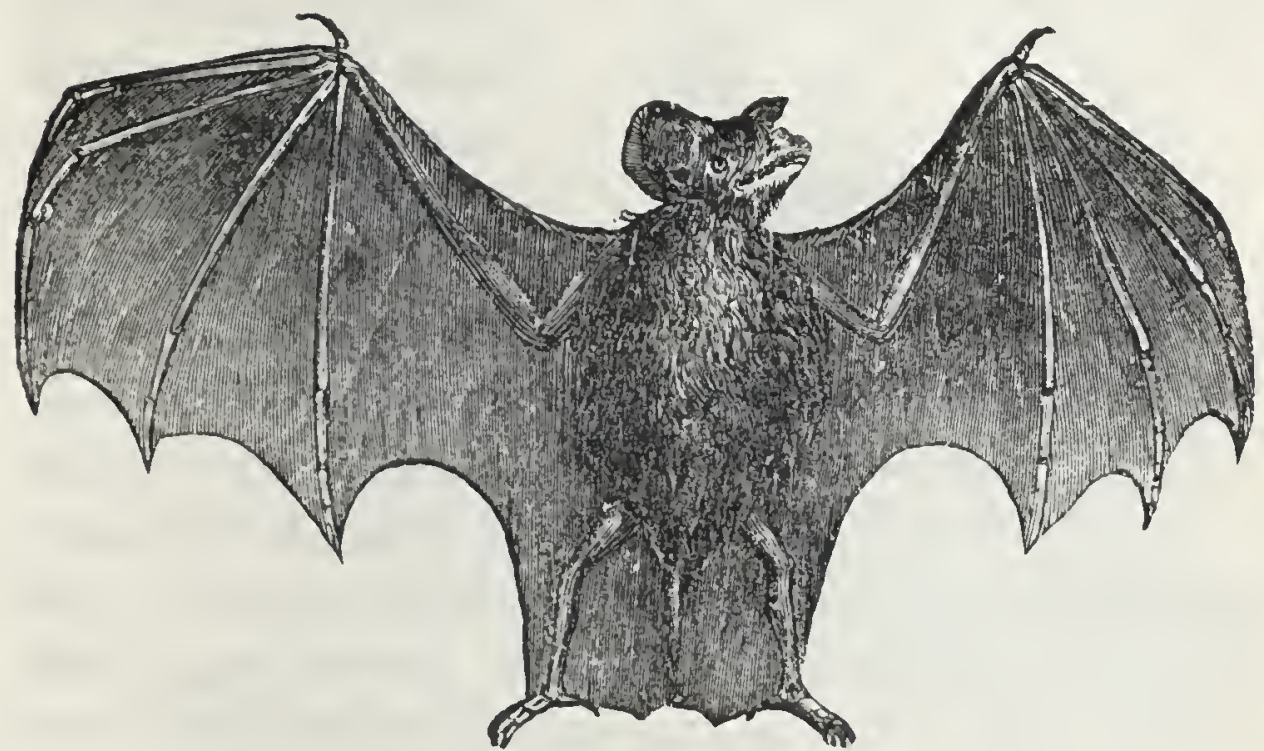

Fig. 207.-BAT.

birds the wing-f'eathers are mostly attached to bones which correspond with those of our arm. But to compare the bones of the Bat's wing with those of the human frame, let us suppose the skeleton of a man with the fore-arm greatly prolonged, and the fingers about a yard and a-half in length. The bones would then form a framework somewhat similar to that of an umbrella, and capable, like it, of being shut or opened. Let us suppose this bony framework covered with some light and pliant material, which is continued between the legs and down to the ankles, and we 
would then have a figure resembling, in the organs of flight, that which is in reality possessed by the Bat (Fig. 207). The elongated or lengthened bones of the fingers form the framework of the wing; and hence the order is named by a scientific term which literally means "hand-winged."

If a Bat be placed on the smooth surface of a table, its awkward attempts at walking (Fig. 208) give an

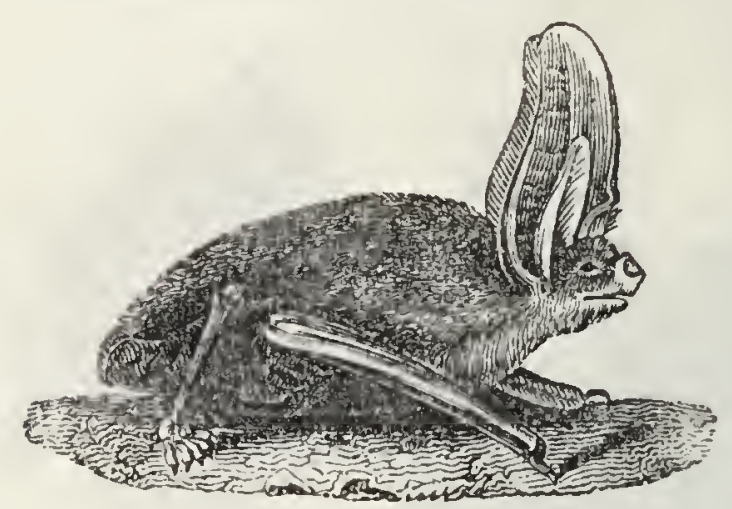

Fig. 208.-Bat Waliking. idea of helplessness akin to that which was suggested to naturalists when the Sloth was seen upon the ground. Yet compassion in both cases would be alike misplaced. Each animal is gifted with powers of movement adapted to its wants. The Bat can climb with ease the rugged and upright stem of a tree, or can wheel its flight in the air, though burdened with one or two young adhering to its teats.

The use of the wings does not seem to be limited to that of flight. They appear to be endued with a most delicate sense of touch-a sense so fine as to be affected by the slightest difference in the vibrations of the air. By the cruel experiments of Spallanzani, it was proved that Bats deprived of sight could fly without striking against walls or other objects, and were even able to avoid coming into contact with threads placed across the apartment in various directions.

Many tribes of Bats, which are natives of foreign 
countrics, have curious leaf-like appendages upon the nose; and these are believed to be organs of smell. The size of some Bats appears very considerable when contrasted with that of our most common native species. There is one in the island of Java, the expanse of whose wings is so much as five feet.

All the very large Bats live on fruits. They belong to the tropics of the Old World, and are very commonly known as Flying Foxes. The Vampire Bats belong to the tropical regions of America. The stories current of the injuries done by them to horses, by sucking their blood, would seem to be much exaggerated.

The distribution of Bats in these countries is worthy of note. While seventeen species are recorded as British, only

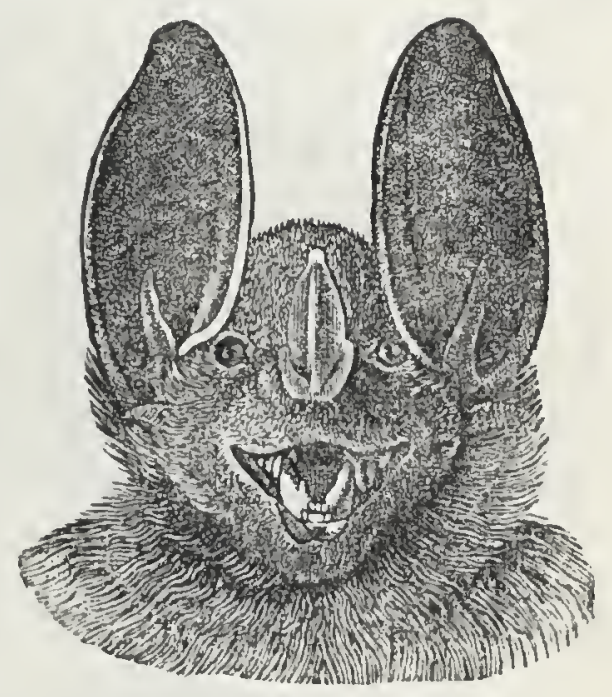

Fig. 209.-Head of Vampire. seven have as yet been discovered in Ireland.

\section{ORDER VI.-TOOTHLESS ANIMALS.}

\section{EDENTATA OR BRUTA.}

Is the Ant-eater of Sonth America we have an example of a quadruped which has no teeth; its long tongue, covered with glutinous matter, being the means employed for entrapping its insect prey. Other 
animals belonging to the present group are not toothless; the true characteristic being the want of teeth in the front part of the jaw-that very part in which, in the gnawing animals, such careful provision seems to have been made for their continual growth.

The present order is composed entirely of foreign species, and has been divided into three groups, one represented by the Ant-eater, a second by the Armadillo (Fig. 210), and the third by the Sloth (Fig. 211). The true Ant-eaters are limited to South America. They are covered with long hair, and have strong claws. With these they tear open the nests of Ants, and then thrusting down into them their long slender tongue, covered with an extremely sticky secretion, bring it back into their mouths covered with Ants. They are represented in the Old World by the scaly Ant-eaters (Manis), or Pangolin, of Asia and Africa.

The Armadillos are peculiar to the New World; no animals encased in a similar bony covering are found

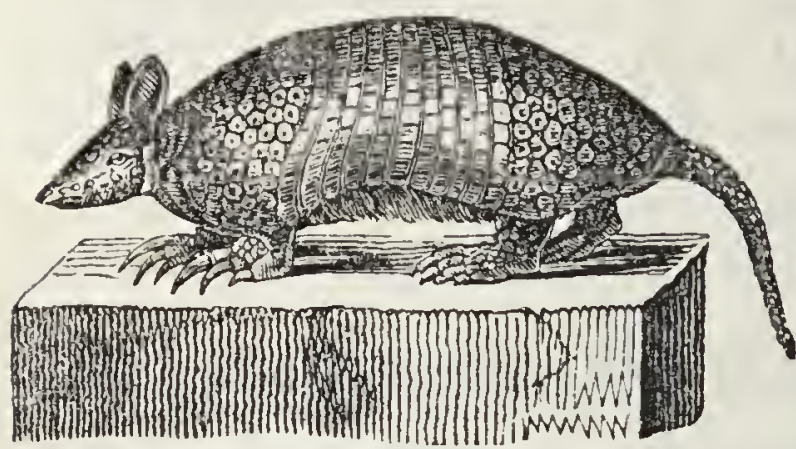

Fig. 210.-ARMADILLO. in any other part of the globe. They extend from the banks of the Orinoco, through the whole of South America, and occupy the lower regions of the Andes to the same elevation as the Sloths, or about 3,000 feet. Their food is partly of animal and partly of vegetable substances and fruits.

The Sloths are found from the southern limits of 
Mexico to Rio de Jameiro. Their food entirely consists of leaves and fruits. The Sloth has been spoken of by naturalists of high reputation as disproportioned in its parts, grotesque, imperfect, and to whom existence must be a burthen. Such opinions have been exploded by a better knowledge of the habits of the animal. It

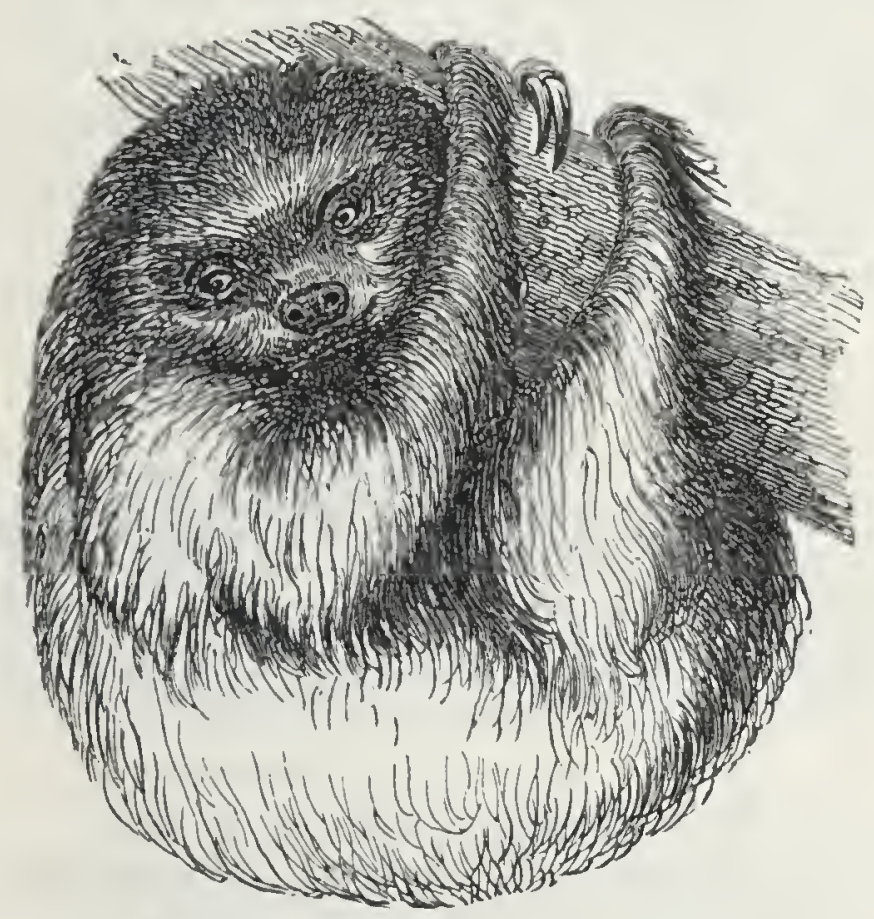

Fig. 211.-UNaU, or Two-toed SLotu.

is not destined to live upon the earth, but among the branches of trees, and not on them, like the Squirrel, but under them. These things being known, each supposed defect of structure turns out to be in reality a new instance of the perfection and wisdom displayed in all the works of Nature.

"The Sloth," Mr. Waterton remarks, "is the only known quadruped that spends its whole life suspended by his feet from the branches of trees. The Monkey and the Squirrel seize a branch with their fore-feet, 
and pull themselves up, and rest or run upon it; but the Sloth, after seizing it, still remains suspended; and, suspended, moves along under the branch till he can lay hold of another."

Gigantic animals of this family have been found in a fossil state in South America. Their bulk equalled that of a Hippopotamus, but with bones much more massive, and muscles proportionally powerful.

Too large for climbing trees, yet destined to live on the foliage, they dug around the base, uprooted the trunks, and then fed upon the leaves.

\section{Order VII.-WHALES, DOLPHINS, PORPOISES.}

\section{CETACEA. *}

\section{"Leviathan,}

Hugest of living creatures, on the deep

Stretch'd like a promontory, sleeps or swims,

And seems a moving land."-Milton.

These animals are distinguished by their fish-like form, their flat horizontal tail, and by the anterior extremities-those which would be called the arms in Monkeys and the wings in birds-being in the shape of fins. They were arranged by Cuvier under two sections-those

* The term Mutilata has been applied to these animals because their hind limbs seem, as it were, to have been amputatcd. Professor Owen forms the herbivorous Cetacea into a distinct order, under the name Sirenia. In some of their characters they approach the succeeding order. 
that live on animal, and those that live on vegetable food. The former group is divided into three families, which may be represented by the Dolphin, the Spermaceti Whale, and the Baleen Whale, in all of which the nostrils are situated on the crown of the head, and act as blow-holes.

The common Dolphin is occasionally met with on the British shores, and is remarkable for the activity and playfulness of its gambols, and its evident delight in companionship. In these respects it resembles the common Porpoise (Fig. 212), which, of all the Cetacea, is the species most usually seen around our coasts,

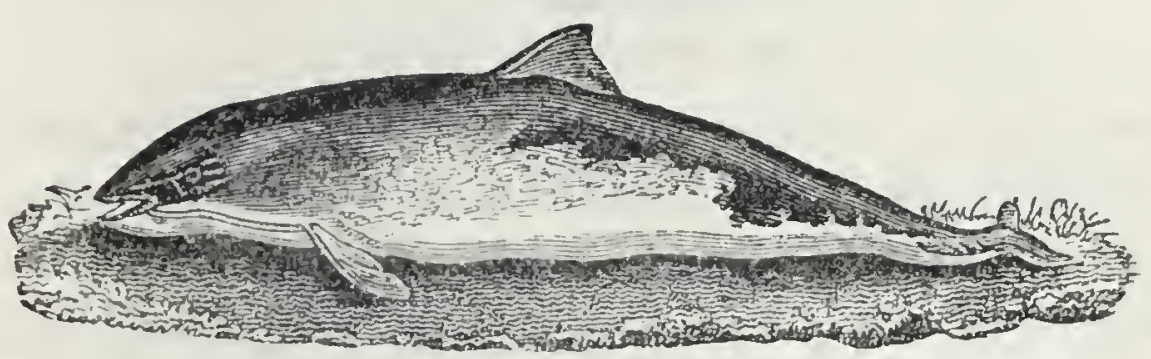

Fig. 212.--PorpoIsE.

entering our bays in pursuit of shoals of herrings, and other fish, and attracting attention by the manner in which it rolls over, as it comes to the surface to breathe. The length of the body is from four to six feet.

The Cachalot, or Spermaceti Whale, derives its common name from the peculiar and useful substance which it affords. The head is of enormous bulk, its length being nearly equal to half the entire length of the animal. The Spermaceti, in a fluid state, is contained in compartments in the front part of the head. The creature reaches the length of serenty feet; and its strength is so enormous, that a ship of large size has 
been stove in and foundered by a blow inflicted by the head of an enraged male Cachalot of large size.

The Common or Baleen Whale (Fig. 213) feeds upon small crustacea, mollusca, and medusæ. This it

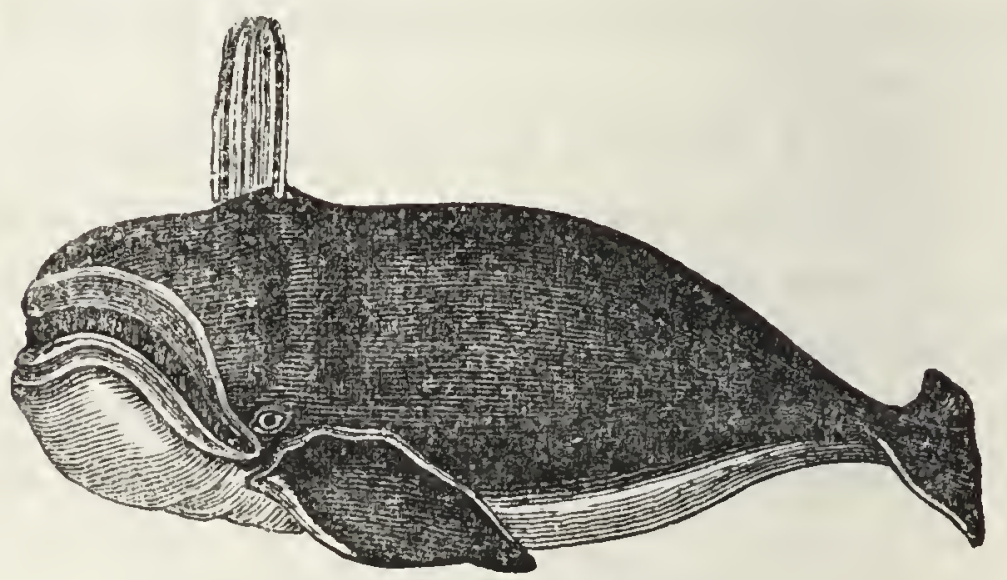

Fig. 213.-Balees Whale.

is enabled to do by a beautiful apparatus, which, acting as a sieve, allows the water to escape, while the minute animals diffused through it are retained. This sieve consists of a series of horny plates (Fig. 214), which

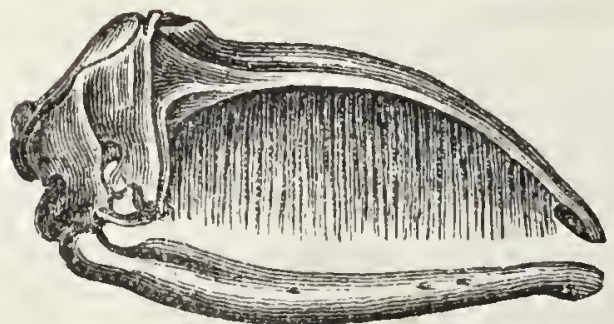

Fig. 214.-SKULL OF WhaLE. hang like a fringe from the upper jaw, and are well known by the common, though not very correct appellation, of "whale-bone."

Other arrangements, no less perfect, are observable in the Whale, and adapt it for being the inhabitant of the arctic seas. The tail, as has been already mentioned, is horizontal, while in fishes it is vertical. By fishes it is used as an instrument for progress in the water, and they may speed onwards in their course at nearly the same uniform depth. But from the very nature of their organiza- 
tion, Whales are compelled to rise to the surface to breathe; and as the tail is horizontal, it acts as an oar of inconceivable power; the surface which it exposes in the larger species being not less than one hundred square feet.

The substance to which we give the name of "blubber" is arranged in such a way as to protect the animal from the pressure of the water, which must be enormous at the vast depths to which it descends; while, at the same time, it acts as a blanket in maintaining the heat of the body. Nor does its utility stop even here; it is specifically lighter than the sea-water, and though its weight sometimes exceeds thirty tolns, it does not act as an incumbrance, but in reality renders the animal more buoyant.

Thus provided, the Rorqual, of ninety or a hundred feet in length, the largest of all Whales, and, consequently, of all existing animals, can propel its enormous bulk through the water, or float at ease upon the surface. Respecting such a creature, Milton, in the following beautiful lines, has recorded a tradition at one time current:-

"Him, haply slumbering on the Norway foam, The pilot of some small night-founder'd skiff Deeining some island, oft as seamen tell, With fixed anchor in his scaly* rind, Moors by lis side under the lee, while night Invests the sea, and wished morn delays."

The herbivorous group frequent the sea-coast, or ascend rivers, browsing on sea-weeds, water plants, and other vegetables. One of these, the Dugong, is abun-

"An old error; the skin is not "scaly." 
dant on part of the coast of Ceylon. Sir E. Tennent gives a figure of the animal in the act of suckling its young, holding it to her breast with one flipper, while swimming with the other. He remarks that the rude approach to the human outline, observed in the shape of the head of this creature while so engaged, her demonstrations of strong maternal affection, and her suddenly diving and displaying her fish-like tail when disturbed, have probably given rise to the fable of the "Mermaid."

\title{
ORDER VIII.-THICK-SKINNED ANIMALS.
}

\author{
PACHYDERMATA.*
}

"Beside him stalks to battle

The huge earth-shaking beast-

The beast on whom the castle

With all its guards doth stand;

The beast who hath between his eyes

The serpent for a hand."

Macaulay's Lays of Axcient Rome.

TuE animals of the present order are, in their general habits, herbivorous. One of their most obvious characteristics is the toughness and great thickness of the skin; from this peculiarity the scientific name for the

* The hoofed Mammals are divided by Professor Owen into the "oddtoed" and the "even-toed." The former are represented by the single hoof of the Horse and the triple hoof of the Tapir; the latter are exemplified by the double hoof of the Camel and the quadruple hoof of the Hippopotamus. 
order has been derived. Most of the species belong to the torrid zone, but none to Australia or Polynesia.

The Elephant is a well-known example of the present order. One species is found in the forests of tropical Asia; a second in those of tropical Africa. These are the only species now living; but geology tells us that, in former times, at least two kinds lived amid the luxuriant vegetation of the South American

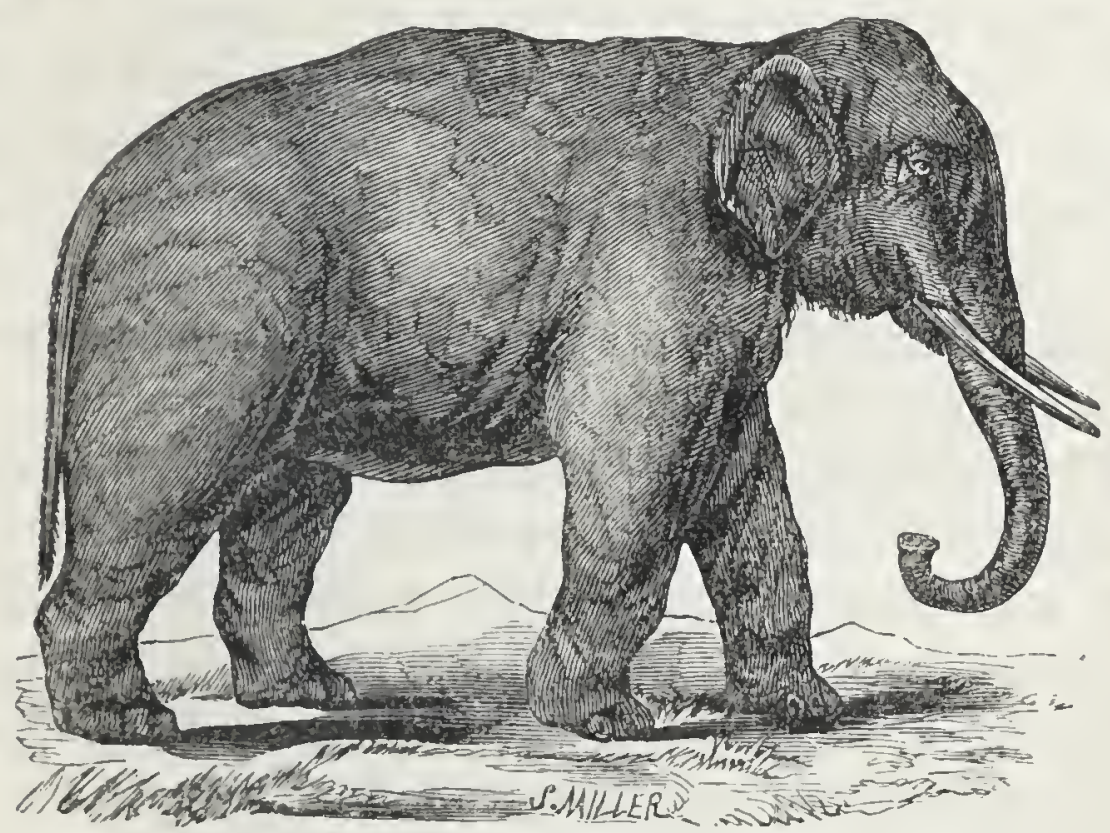

Fig. 215.-Indian Elephant.

rivers, and two others in the warm and temperate latitudes of North America. At a later period a lunge Elephant, clothed with wool and hair, existed, not only in temperate but in high northern latitudes, in Europe, Asia, and America.

The food of the Eleplant, when in a state of nature, consists not merely of leaves, but of the twigs and branches of trees. It is needful, therefore, that he should have teeth fitted to grind down the woody fibre, and with some power of renewal which would make 
up for the continual wearing away. The teeth are, therefore, composed of three substances of different degrees of hardness; this causes the surface to wear away in an unequal manner, and hence the property which makes a millstone most valuable is secured. The arrangement to make good what a mechanic would call "the wear and tear" of the apparatus is not less effectual. The teeth are ever growing, not as in the gnawing animals (page 204), by the deposit of fresh matter at the base, but by the development of new teeth. These appear in succession as they are wanted; so that although an Elephant may have in each jaw not less than six of these enormous molar teeth in the course of its life, or twenty-four in all, never more than two are seen in each jaw at the same time.

The Elephant, both of India and of Africa, has been celebrated for his strength, docility, inoffensive habits, and usefulness to man; and the term "half-reasoning Elephant," which has been applied to him by the poet, indicates that remarkable sagacity of which so many well-authenticated anecdotes are told.

Those who have had the opportunity of observing a herd of Elephants in their native haunts describe them as gentle, timid, and indolent. "A few are generally browsing listlessly on the trees and plants within reach, others fanning themselves with leafy branches, and a few are asleep; whilst the young run playfully among the herd, the emblems of innocence, as the older ones are of peacefulness and gravity."* On one occasion, when a herd of between 80 and 100 had, under the guidance of a leader, entered one of the large water

$$
\text { " History of Ceylon, vol. ii., p. } 328 .
$$


tanks in Ceylon, the noise occasioned by breaking off a small twig was sufficient to put them all to flight, "like a herd of frightened deer:" *

The Elephant when in captivity is taught to use his tusks for moving stones and piling timber, and a powerful one will raise and carry a $\log$ of half a ton weight or more. Sir E. Tennent, on one occasion, while riding near Kandy, saw that his horse was excited by a sound that came out of the thick jungle. "A turn in the forest," he says, "explained the mystery, by bringing me face to face with a tame Elephant, unaccompanied by any attendant. He was labouring painfully to carry a heavy beam of timber, which he balanced across his tusks, but the pathway being narrow, he was forced to bend his head to one side to permit it to pass endways; and the exertion and inconvenience combined, led him to utter the dissatisfied sounds which disturbed the composure of my lorse. On seeing us halt, the Elephant raised his head, reconnoitred us for a moment, then flung down the timber, and forced himself backwards among the brushwood, so as to leave a passage, of which he expected us to avail ourselves. My horse still hesitated; the Elephant observed it, and impatiently thrust himself still deeper into the jungle, repeating his cry of urmph! but in a voice evidently meant to encourage us to come on. Still the horse trembled; and anxious to observe the instinct of the two sagacious creatures, I forbore any interference; again the Elephant wedged himself farther in amongst the trees, and waited impatiently for us to pass him; and after the horse had 
done so, tremblingly and timidly, I saw the wise creature stoop and take up his heavy burthen, trim and balance it on his tusks, and resume his route,

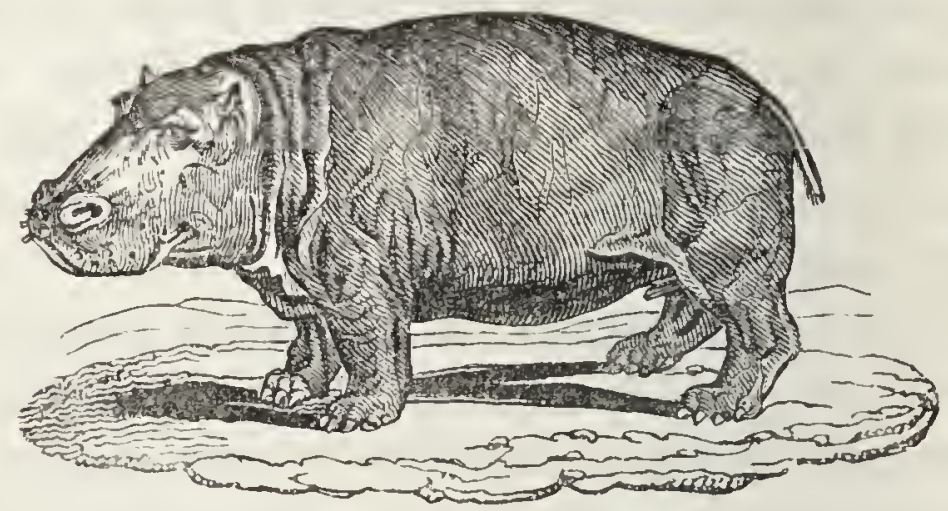

Fig. 216.-Hippopotanus.

hoarsely snorting, as before, his discontented remonstrance."*

The Hippopotamus or River-horse (Fig. 216), whose bulk is scarcely inferior to that of the Elephant, is

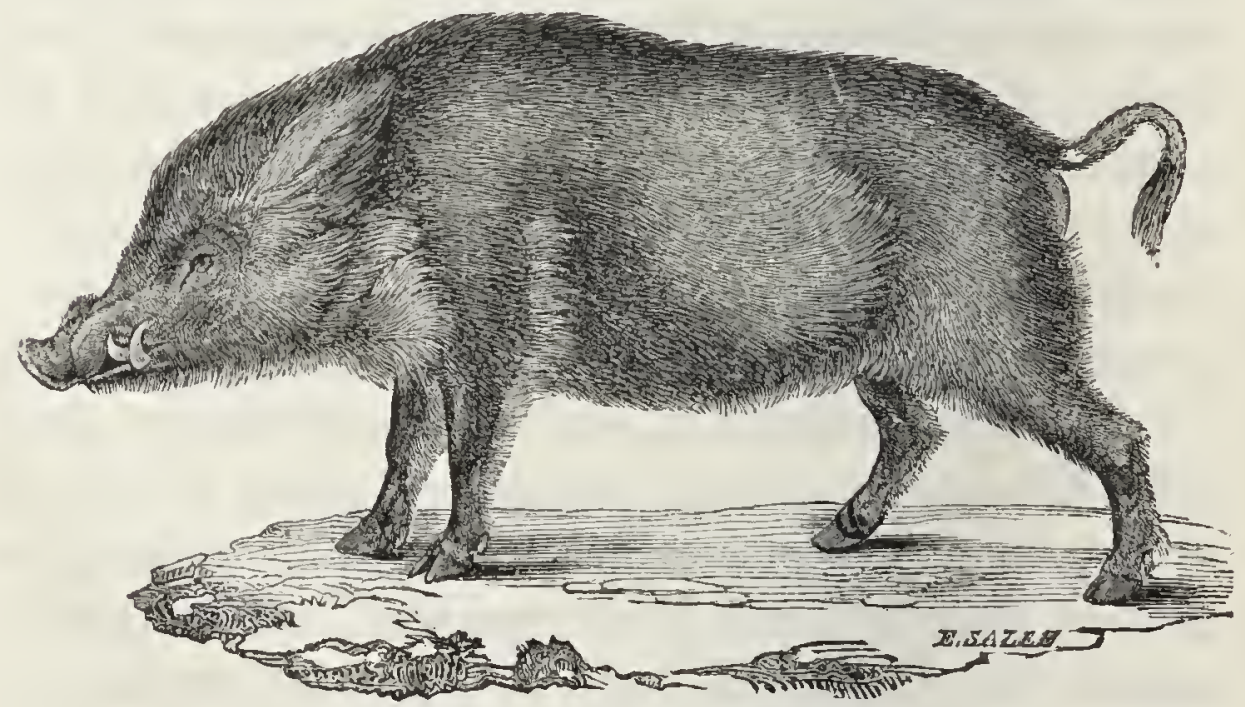

Fig. 217.-WILD BOAR.

another example of this order. It is a native of Africa, frequenting rivers, and feeding on the herbage that

* History of Ceylon, vol. ii., p. 282. 
flourishes on their banks. The Rhinoceros is found both in Asia and Africa, all those belonging to Africa being two horned. A species at one time lived in Europe, warmly clad, and adapted for a cold climate. The true Swine of the Old World (Fig. 217) are represented by the Peccaries in the New.

Two species of Tapir are found in America, and one in the island of Sumatra. Its most remarkable feature consists in the prolongation of the nose into a novable proboscis, which extends sereral inches beyond the month, and is capable of being moved at will in various directions (Fig. 218). The Tapir is found in every part of South America, from the Straits of Fig. 218.-IIEad of Tapir. Magellan to the Isthmus of Darien; it is extremely inoffensive, and never attacks either man or beast, except in self-defence, or under circumstances of great provocation. It is about the size of a calf of six. months old.

The family to which the Horse belongs is universally distributed, either in a wild or a domesticated state. On its first appearance in South America, it was an object of terror to the inhabitants, bearing on its back their Spanish conqueror. A species of Horse had existed both in North and South America, and had probably perished before the soil of that continent had been trodden by human foot. Its remains are found along with those of the gigantic Sloths, and other bulky quadrupeds of a former epoch. The troops of wild Horses that now live amid the abundant vegetation 
of the American plains are therefore the descendants, not of the native species, but of the European, which was introduced by the Spaniards. The wild Asses extend from Siberia to Egypt; and the clifferent species

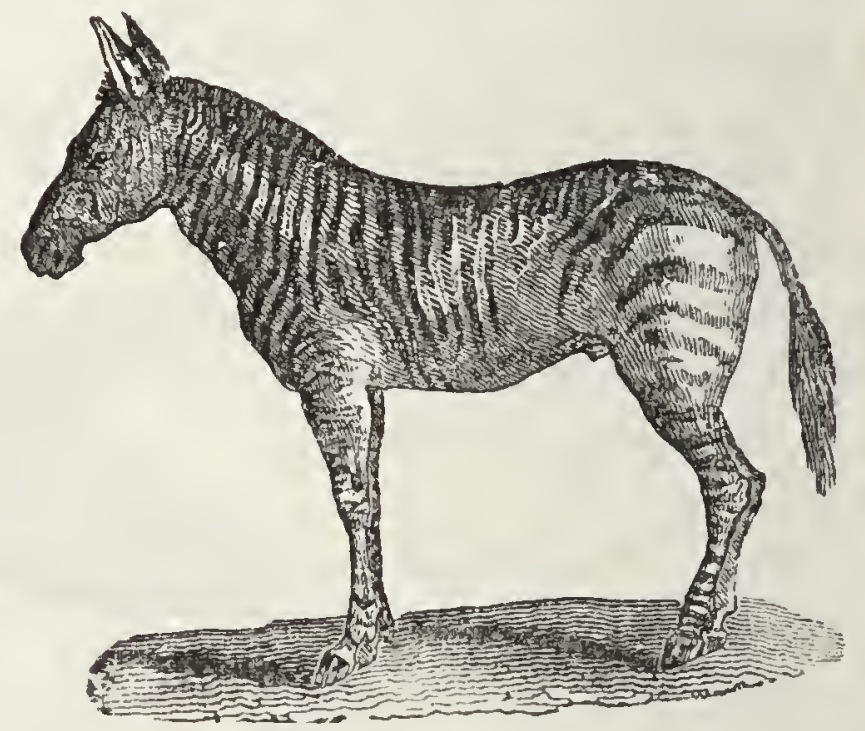

Fig. 219.-ZEBRA.

of Zebra (Fig. 219) throughout central and southern Africa, some inhabiting the plains, others selecting the mountains.

\section{Order IX.-RUMINATING ANIMALS.}

\section{RUMINANTIA.}

The ruminating animals are distinguished, as their very name imports, by their habit of ruminating or chewing the cud. Their stomachs are divided into four cavities; they live ou vegetables, and are all possessed of what is called the "cloven hoof." Here only do we 
meet with species having the forehead armed with horns; every quadruped with horns so placed is, therefore, a ruminating animal.

They are widely spread over the earth, from the equator to the icy regions of the arctic circle; so that, wherever man is found, he is accompanied by those animals most necessary for the supply of his wants and comforts. From them he derives a considerable portion of his food and clothing, whether in a savage or civilized state of society. Their milk, their flesh, their wool, hides, horns, and hoofs, are all converted to his

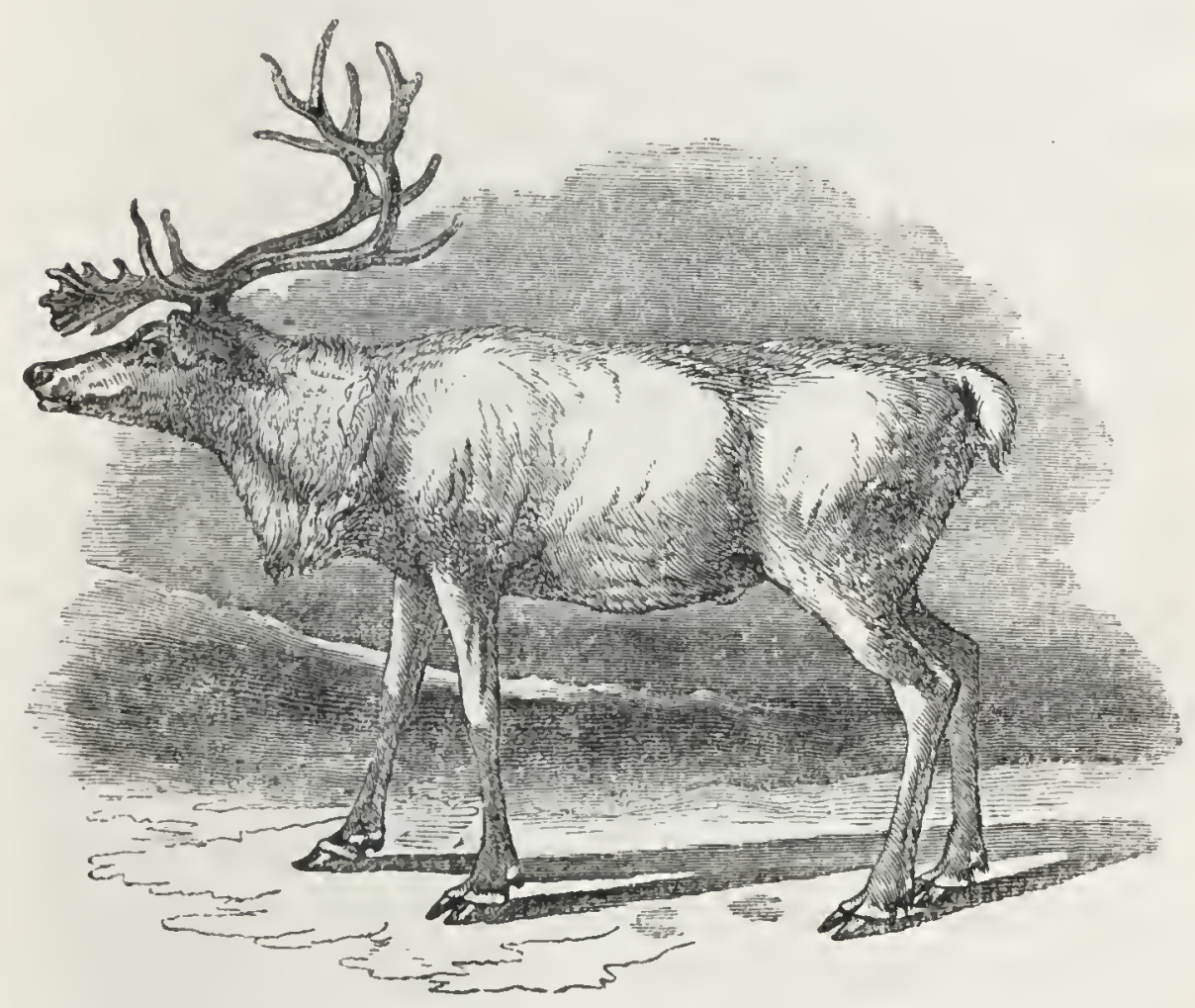

Fig. 220.-REINDEER.

uses; whilst from many of them he receives the most valuable assistance in the labours of the field, and in the transport of commodities. Thus, the Reindeer (Fig. 220) is to the Laplander his chief source of 
comfort and principal means of subsistence. It furnishes him both with food and raiment; and in a country where neither the Horse nor the Cow could live through the winter, it supplies the place of both.

The ruminating animals may be conveniently divided into eight groups.

I. The Camels and the Llamas may be placed together. They differ from most other animals of the present order in the absence of horns, and in the possession of a pair of incisor or cutting teeth in the upper jaw.

The Arabian Camel, from the earliest ages to the present day, has formed the chief means of communication between the different countries of the East, and has been, in the sultry regions where it is found, scarcely less important to man than is the Reindeer amid the snowy wastes of Lapland.

The Llamas have been justly termed the "Camels of the New World," and differ from them in being of smaller size, and in the absence of the hump. They belong exclusively to South America; and unlike their Old World relatives, who inhabit "Araby the blest," and other sunny regions, they are found amid the bleak and rocky precipices bordering on the limit of perpetual snow. As beasts of burden their powers are very limited; a weight of from one to two hundred pounds is a sufficient load for one of them, while the Camel will bear six or eight hundred pounds, or even so much as one thousand.

II. The Musk Deen, from which the substance called "musk" is procured. They are chiefly natives 
of Asia; in the absence of liorns and in some other particulars they resemble the Camels.

III. The DeEr. These animals combine, in the highest degree, the characteristics of elegance of form, grace, and fleetness (Fig. 221). The Elk or Moose Deer of America exceeds in size any species now living. It was, however, much surpassed by that extinct species known as the "Irish Elk," and especially as regards the size of the antlers, which weighed

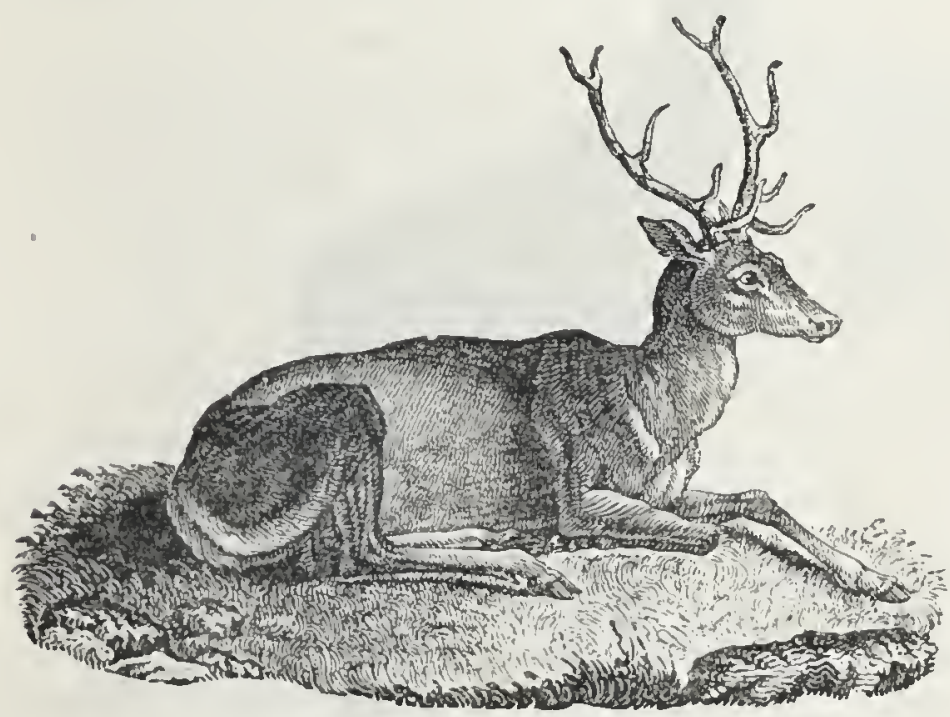

Fig. 221.-The StaG.

from 60 to 70 lbs. In the Moose the span of the antlers between the extreme tips is four feet; in the extinct Irish species it is eight feet, or even more.

The three species of Deer now living in these countries are the Fallow Deer, the Red Deer, and the Roebuck. The horms are shed every year; as they were in the extinct species, and their place supplied by a new growth. The horns are solid, and in their structure resemble bone.-Those of the $\mathrm{Ox}$ or the Goat, on the contrary, are hollow, covering 
the bony portion as a sheath would do, and are formed of that elastic substance to which we give the name of horn. From the difference in the structure of their horns, therefore, animals of the present order may be grouped as solid, or as hollow-horned, ruminants.

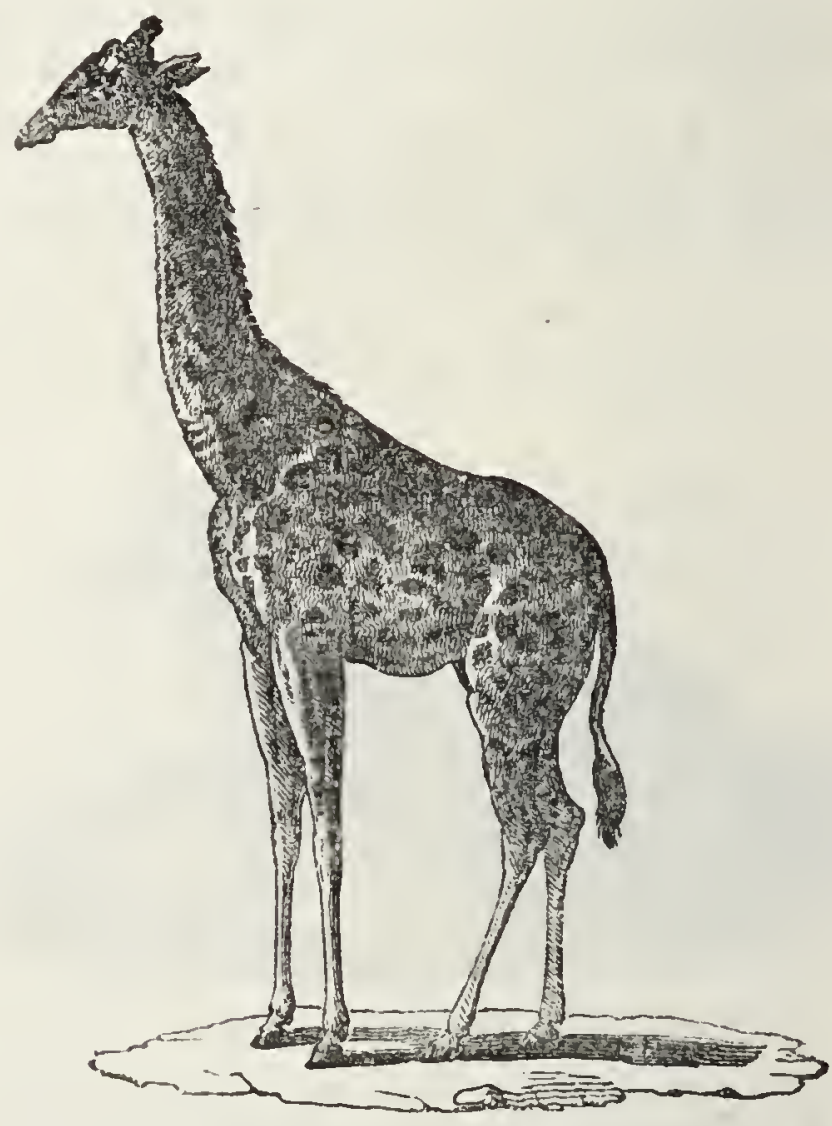

Fig. 222.-GIRAFFE.

IV. The Giraffe or Camelopard (Fig. 222) is now confined to the continent of Africa. It browses upon the foliage and tender shoots of trees, and has a tongue so formed as to serve, like the proboscis of the Elephant, as an instrument for pulling them down.

V. Antelopes. - The traveller among the Alps or the Pyrenees describes one species of this group, the Chamois, and the poets of Eastern tale have 
celebrated the praises of another-the Gazelle (Fig. $223),-$

"Her eye's dark charm 'twere vain to tell,

But gaze on that of the Gazelle,

It will assist thy fancy well;

As large, as languishingly dark."-Byrow.

One beautiful species, the Indian Antelope, is common in the North of India. By means of their extreme swiftness, and the great length of their bounds, they can distance the fleetest dogs. They are, however, sometimes surprised by the Chetahs, or Hunting Leopards, trained for the purpose, and are also occasionally flown at by hawks, which keep them occupied until the dogs have time to come up with them and seize them.

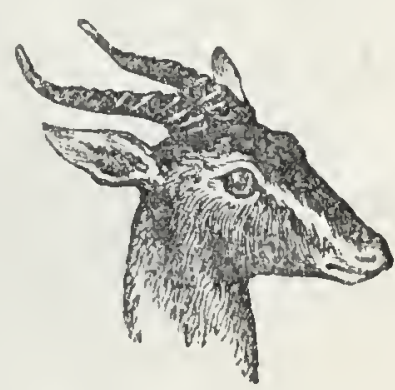

Fig. 223.-GAZELLE.

Africa is, however, the head-quarters of the Antelope family. The species are numerous, and the individuals so abundant that the herds of them are described by travellers as consisting occasionally not only of thousands, but of tens of thousands. To the wayfarer or the sportsman in those regions, a knowledge of the peculiar habits of some of these animals may at times be of the utmost importance. Thus Gordon Cumming relates, that when greatly exhausted by want of water, he saw a "Sassayby," or "Sassabe," a kind of Antelope that drinks every day. Assured by this that water was not far distant, he watched the flight of two small flocks of birds going to and returning from the spring, and was thus guided to what he sought. 
The largest of all the Antelopes is the Eland. Several of these are becoming naturalized in these kingdoms, and are now living in the parks of English noblemen. The weight of one when full grown is from 1,500 to 2,000 pounds, so that the quantity of food it would furnish would be equal to that afforded by two good-sized Oxen, such as are usually slaughtered for our markets. An Eland was killed some time since in England, to test its quality as a dish for the table, and the venison was pronounced excellent by all who had the good fortune to partake of it.

Moore has noticed, in one harmonious stanza, the graceful movement of the Antelope, and the nature of the localities in Arabia in which it is found,-

"Our hills are bare, but down their slope

The silv'ry-footed Antelope,

As gracefully and gaily springs

As in the marble court of kings."

VI. The Goats constitute the next family; they are inhabitants of Alpine regions. Some of those which are natives of Thibet furnish a long silky wool, which forms the material of the much prized Cashmere shawls.

VII. The seventh family consists of the different species of SHEEP, which may be traced originally to Western Asia. In a wild state they herd on mountainous districts. The Sheep was probably the first animal reared to furnish food and clothing to man; and it is mentioned in our earliest records, both sacred and profane.

VIII. The remaining group may be represented by our domestic OxEN, which have ever been associated 
with the field labours and the domestic comforts of man. Perlaps no species has been more celebrated than the Bisons (Fig. 224), which roam in numerous herds over the trackless prairies of America. They wander from place to place, either from being disturbed by hunters, or in quest of food. They are partial to the soft tender grass which springs up after a fire has spread over the prairie; and in winter

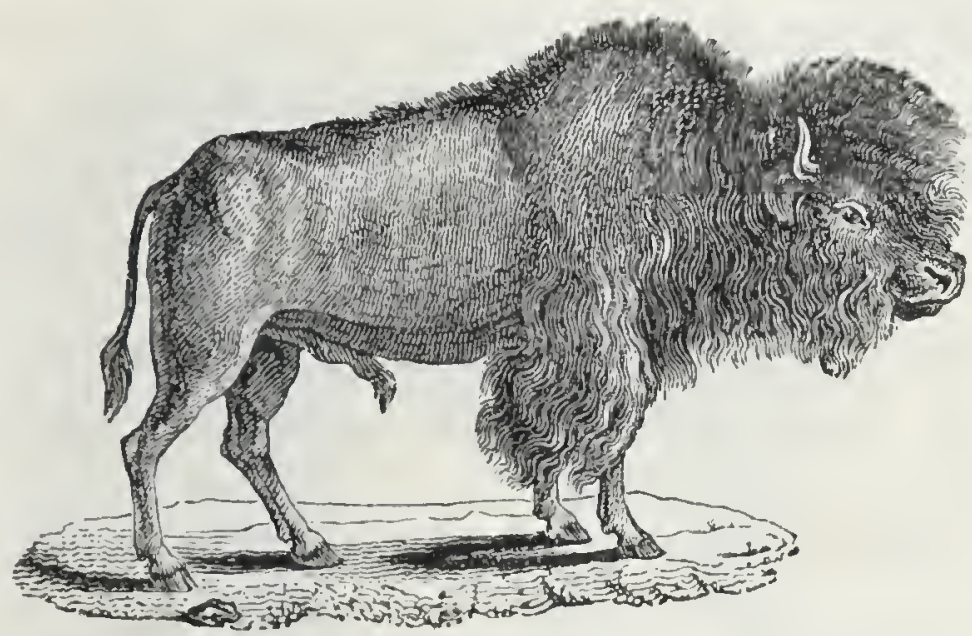

Fig. 224.-Brson.

they will scrape away the snow with their feet to reach the grass. The vast herds in which they appear at times surpass anything we can conceive. Lewis and Clarke, who witnessed more than once the grand spectacle presented by an assembly of Bisons, say, on one occasion-"If it be not impossible to calculate the moving multitude which darkened the whole plains, we are convinced that 20,000 would be no exaggerated number:" 


\section{Order X.-FLESH-EATING ANIMALS.}

\section{CARNIVORA.}

THE animals belonging to the present order are those which live principally upon the flesh of other vertebrate animals, and in popular language are termed beasts of prey. They are readily distinguished from all others by their teeth, which are formed for cutting and tearing flesh. Their limbs present three modifications. In the Seal tribe both fore and hind legs are spread out into paddles for swimming. In the Bear tribe the whole, or nearly the whole, of the hind feet forms a sole, on which they walk. In the Cat tribe the toes only touch the ground, the heel being much raised.* 'The Carnivora have been arranged in five families.

I. The first is that of the SEals (Fig. 225). Like the

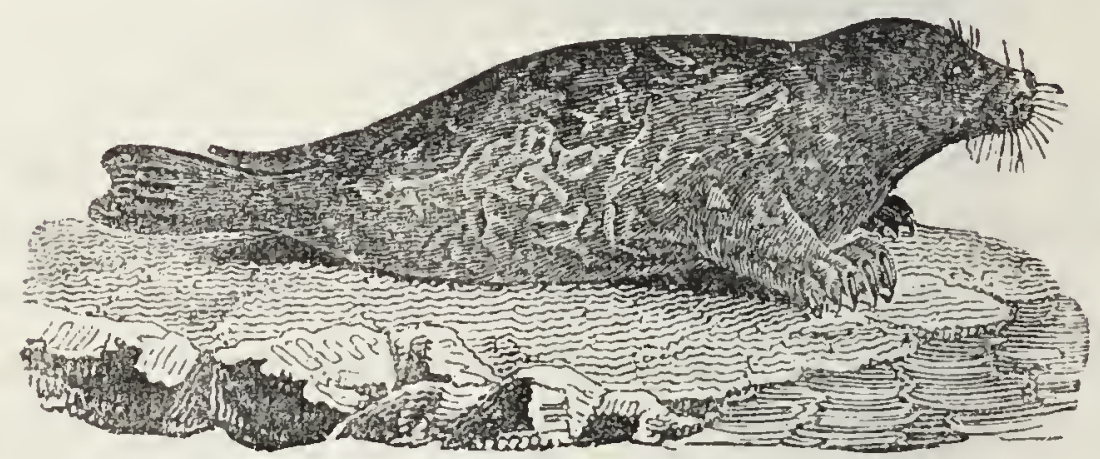

Fig. 225. -SEAL.

Whales, they are warm-blooded Mammalia, living in the sea; but they are at once distinguished from them by the absence of the broad, flat, horizontal tail, the presence of the four feet already mentioned, and other peculiarities. Their great haunt is the sea of the

"Hence the terms "Pinnigrade," "Plantigrade," and "Digitigrade." 
arctic regions; and the fishery, for so it is termed, is one of great value, both for the oil and the skins.

II. The Besrs are remarkable for their great strength, their heavy body, and their peculiar gait. The food of the American Black Bear is chiefly vegetable; that of the Polar Bear is flesh, mostly that of Seals. The Brown Bear (Fig. 226) is found

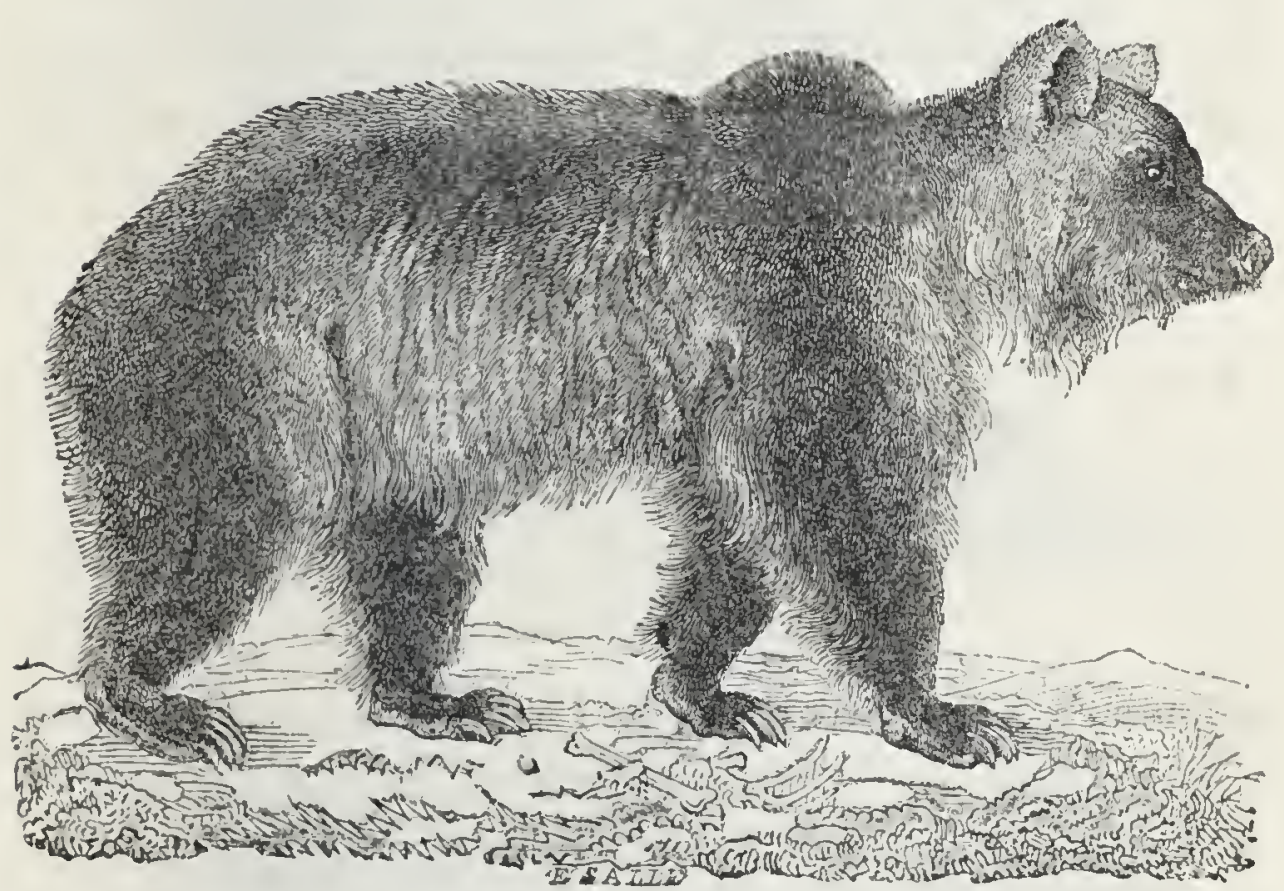

Fig.226.-Brown Bear.

in the mountainous parts of the continent of Europe, and was formerly a native of Britain. Bears belong to Europe, Asia, Africa, and America; but those of the temperate and warm latitudes of the New World are distinct from the species of the Old World.

III. The family of the Weasels (Fig. 227) includes some well-known species: one of these is the Otter, which lives principally upon fish, and has been sometimes taught to aid the fisherman in lis labours. All 
these animals are remarkable for the slenderness and flexibility of their bodies. The Marten takes up its abode in the hollow trunks of trees, and lives upon small birds, which it captures by the great activity of its movements. The Ermine Weasel, or Stoat, like the Alpine Hare, or the Ptarmigan, changes the colour of its covering in winter to a snowy white. The fur is then in that condition in which it is most valuable, the pure white of the skin contrasting with the deep black colour of the tail. It is this animal which is

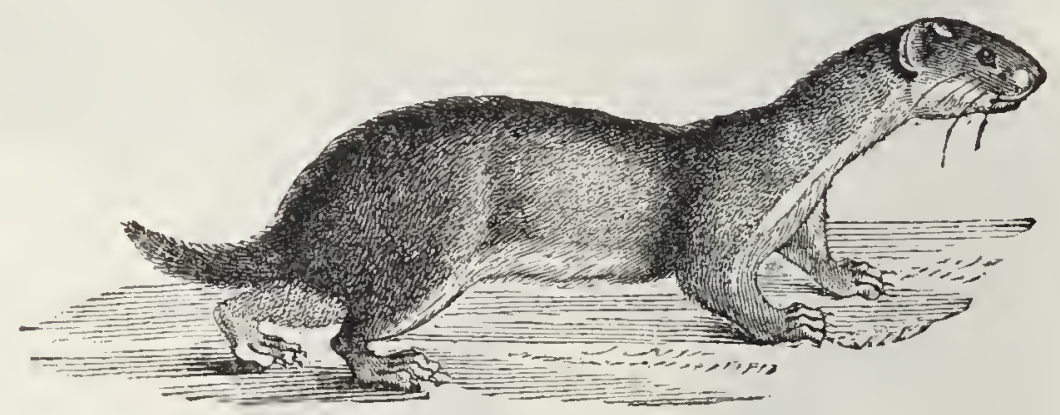

Fig. 227.-WEasel.

commonly called the Weasel in Ireland; and in that country the fur does not appear to change its colour. Mr. Thompson says in his Natural History of Ireland, "Towards the end of our most severe winters in the north, I never saw any change of fur in these animals." Yet in the part of Scotland nearest to Ireland the Stoat becomes white every winter.

IV. The various races of the Dog belong to this family; and although they differ so much from each other, the opinion prevails that they have all had a common origin. The Fox and the Wolf are members of this group; and the Wolf (Fig. 228), in the opinion of Professor Bell, is the source whence all our domestic Dogs have sprung. 
In Thibet there is a race of Dogs of gigantic size. They are the Watch-Dogs of the table-land of the

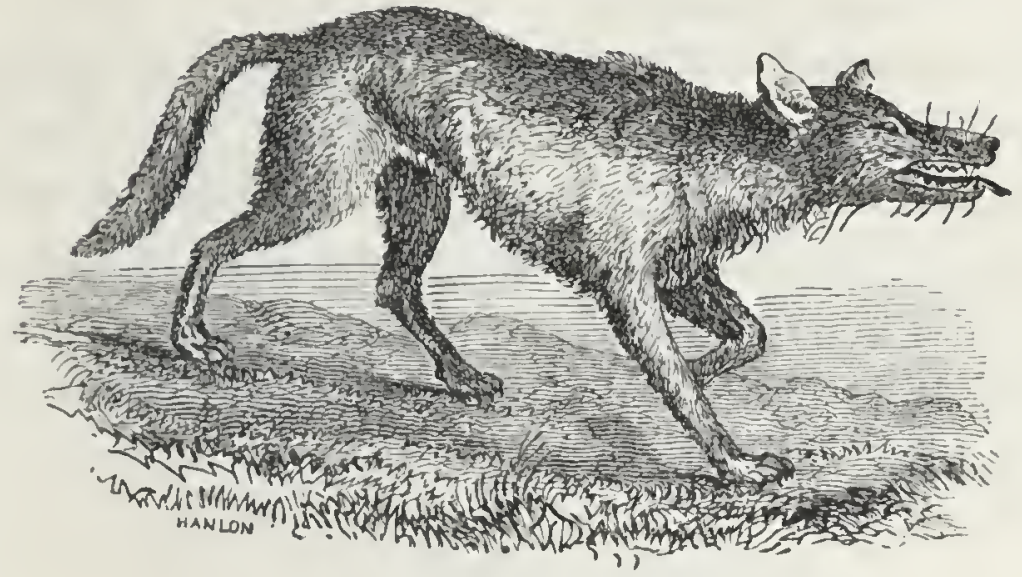

Fig. 228.-WOLF.

Himalaya mountains, and are said to have a great aversion to strangers.

V. The Cat Family. This includes the Lion, the Tiger, the Leopard, the Puma, and other quadrupeds

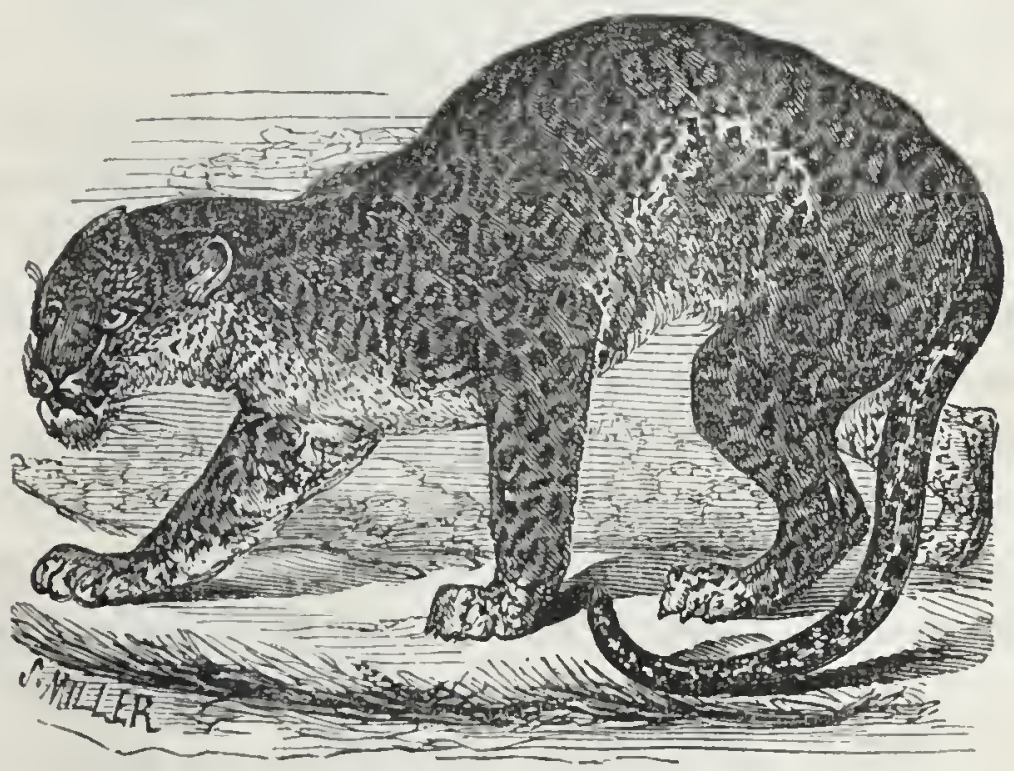

Fig. 229.-LEOPAKD.

remarkable for their destructive powers. They serve to keep within bounds the excessive multiplication R 2 
of the smaller Mammalia, and are widely distributed. The Wild Cat is now the only representative of the group in these countries.

The Leopard (Fig. 229) is a native of Southern Asia, and of nearly the whole of Africa, inhabiting the woods, and preying chiefly on Antelopes, Monkeys, and the smaller quadrupeds. It climbs with great ease. The individual represented in the annexed figure was at one time living in the Zoological Gardens in London.

\section{ORDER XI.-MONKEYS.}

\section{QUADRUMANA.}

Trrose who have visited a zoological garden, or at well-stocked menagerie, cannot fail to have been amused at the freaks and gambols of the Monkeys; and after watching for a time their agile movements and grotesque attitudes, must have been struck with the peculiar formation of the extremities, both of the feet and of the paws. The feet are not shaped like ours, but resemble hands, being furnished witl fingers and with thumbs. In fact they do not perform the duties of feet only, but of hands also. Hence that order to which the Monkeys belong bears a scientific name, signifying "four-handed." It may be divided into three groups: the Lemurs, the Monkeys of America, and those of the Old World.

The Lemurs are natives of Madagascar, and one or two smaller islands in its neighbourhood. In form of 
body they bear a resemblance to a Cat, but the muzzle is pointed like that of a Fox, hence they are sometimes called Fox-nosed Monkeys. It will be seen from Figure 230, that each of the four extremities is furnished with a thumb, which acts in a direction opposite to that of the fingers; and it is a curious characteristic that one of the finger's or "digits" on each of the hind limbs has a claw instead of a nail. These animals come forth in the forests at night, and feed on fruits, insects, and young birds. The Ring-tailed Lemu (Fig. 230), one of the best known

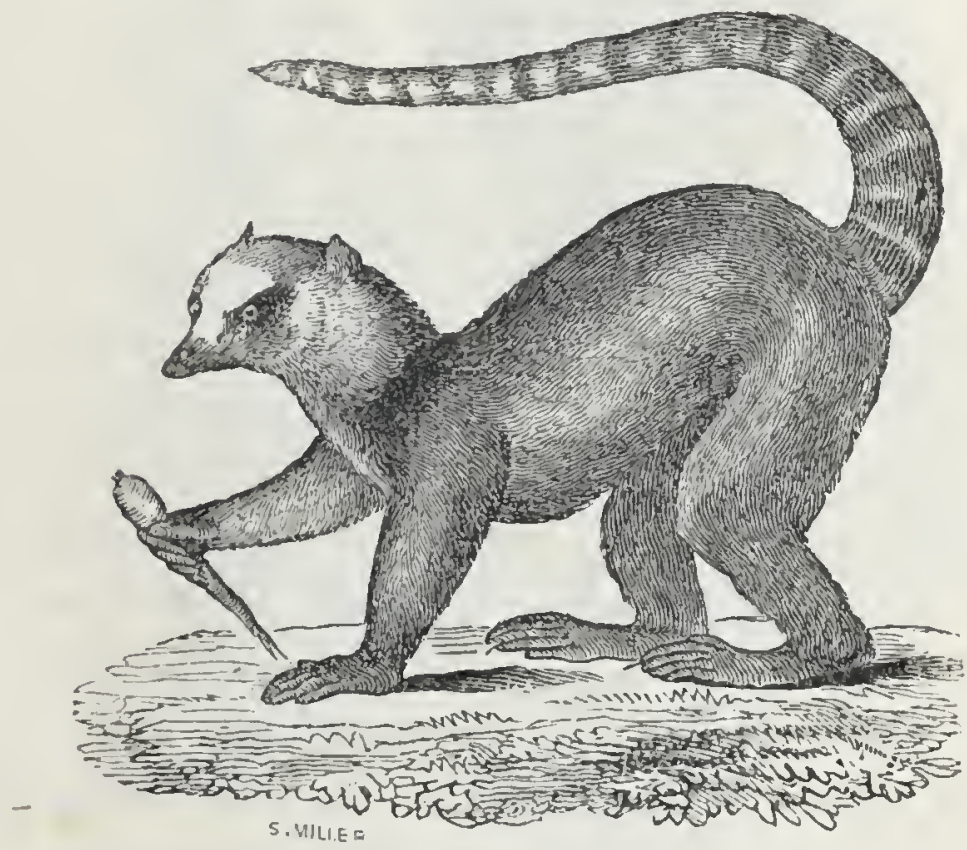

Fig. 230.-Ring-tailed Lejor.

species, is about the size of a large Cat, and is remarkable for its gentle and playful disposition.

The American Monkeys, unlike the Lemurs, can only use the thumb belonging to the fore paws in a line with the other fingers, and in several of then, as in the Coaita (Fig. 231), the thumb on the fore limbs or 
paws is altogether wanting. That on the feet can, however, be employed with the same ease and freedom as in any of the other tribes.

This Monkey is one

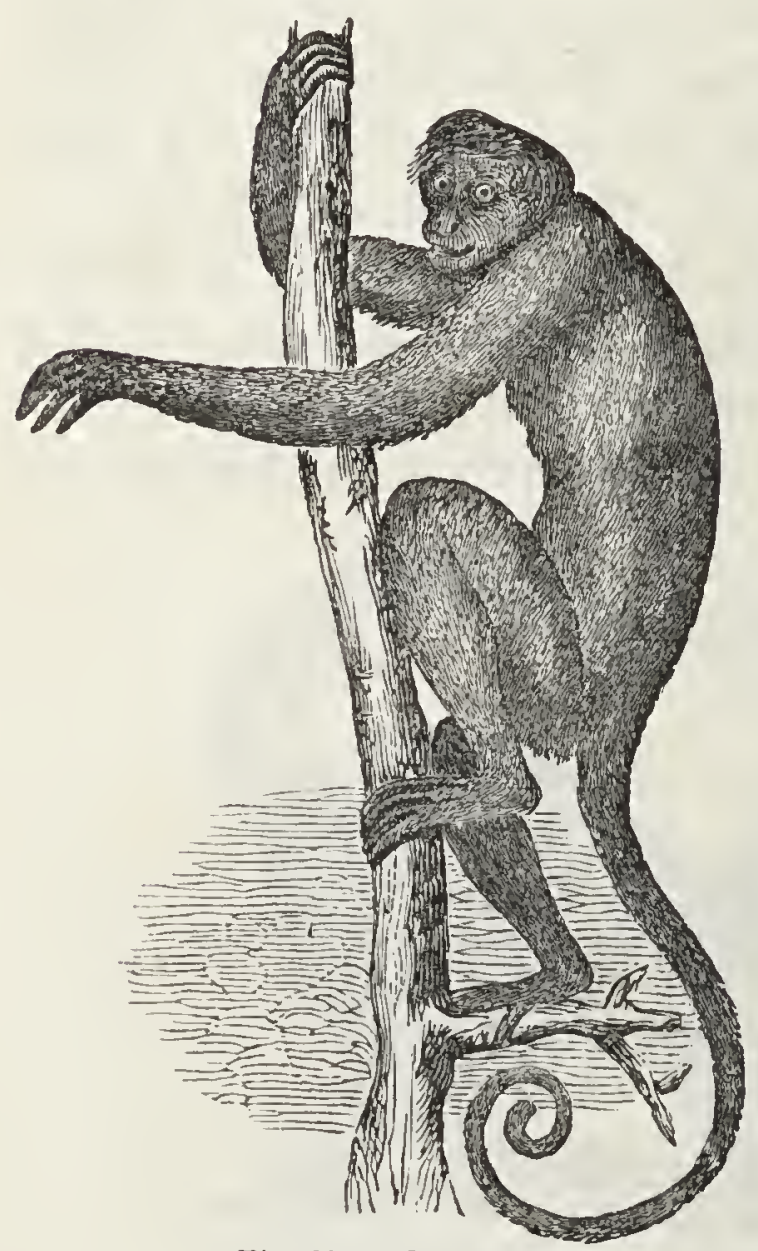

of those which from the length and slenderness of their limbs are called Spider Monkeys. Itis found over the greater part of the South American continent. The tail, like the limbs, is long, and is very muscular; by it they can swing suspended from the branches of trees, or they can use it as a fifth hand. One of these animals has been seen making off with three ears of Indian corn, one in its mouth, one under its arm, and the third in its tail! Their food is partly animal, such as insects, eggs, and fishes.

In the Quadrumana of the Old World, the thumb of the fore limb can be opposed to each of the fingers. They are distinguished in common language by the narres of Apes, Monkeys, and Baboons. In the most highly organized family the tail is absent. Like the Monkeys of the American continent, they are linited to the torrid regions, and are, therefore, natives of Asia 
and Africa. To this there is only one exception, the Barbary Baboon, a native of Northern Africa, which has established a colony on the Rock of Gibraltar.

Among the Apes there are two species of Orang,

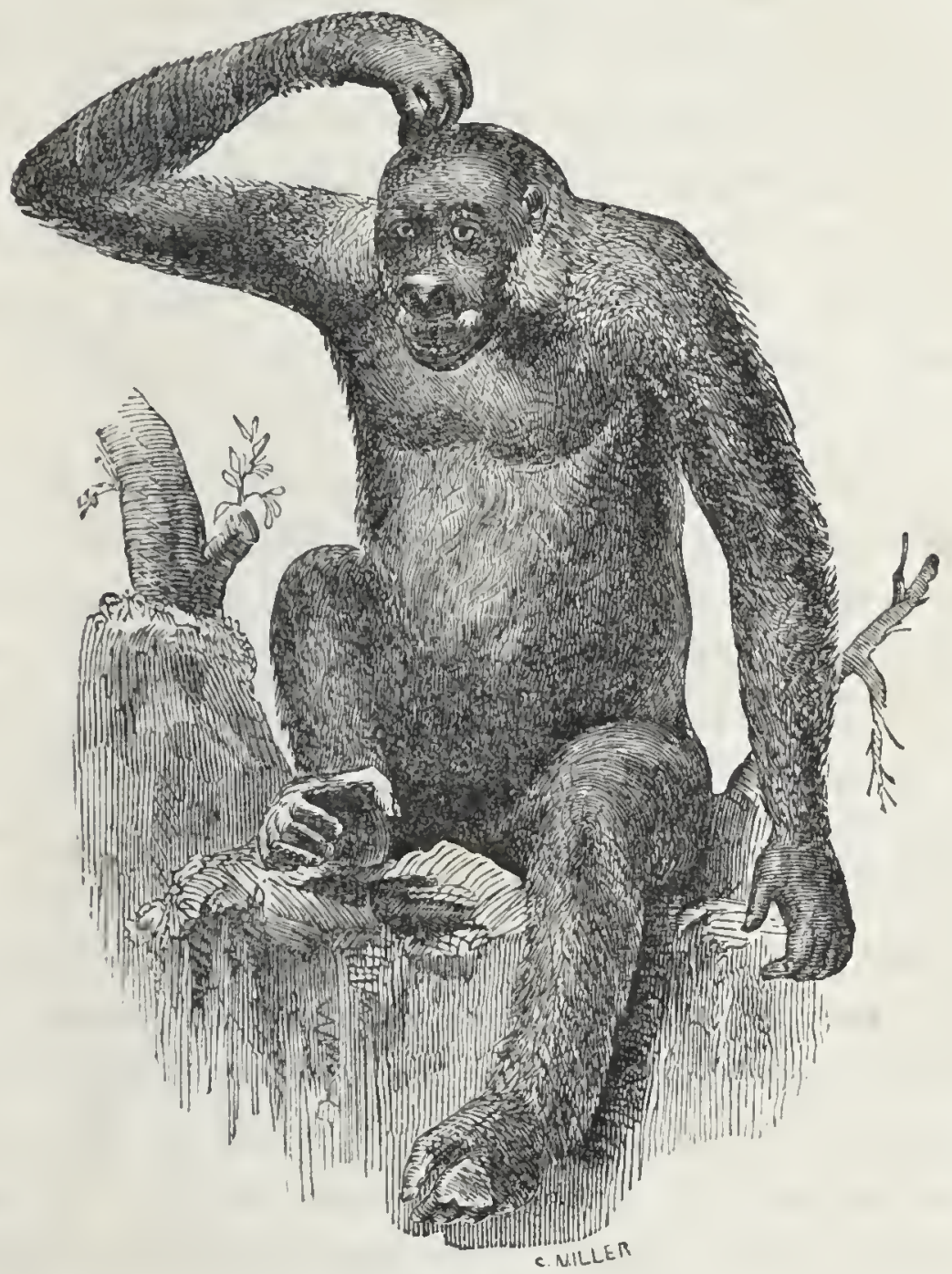

Fig. 232.-GORILLA.

which belong to Borneo and Sumatra, and two species of Chimpanzee, which are limited to Western Africa. Numberless anecdotes are related of them, which prove their intelligence and docility.

The existence of a larger and more powerful Ape, 
called the Gorilla (Fig. 232), which inhabits a part of Western Africa, has recently been made known, and specimens preserved in spirits have reached the museums of Paris, Vienna, and London. The height of the Gorilla, when full grown, is about five feet six inches, his breadth across the shoulders nearly three feet, and his strength is such as to make him a match for the lion, whose tusks his own almost rival.

Professor Owen gives us the following interesting particulars, which he considers the "most probable or least questionable" of the stories told of this extraordinary animal.

"The Gorilla makes a sleeping place like a hammock, connecting the branches of a sheltered and thickly leaved part of a tree by means of the loug tough slender stems of parasitic plants, and lining it with the broad dried fronds of palms, or with long grass. This hammock-like abode may be seen at different heights, from ten feet to forty feet from the ground, but there is never more than one such nest in a tree."

When the young men of the Gaboon tribe make annual excursions into the forests, the enemy they most dread is the Gorilla. He is described as coming rapidly to the attack, swinging down to the lower branches, and clutching at the nearest foe, his green eyes flashing with rage, "If fired at and not mortally hit, the Gorilla closes at once upon his assailant, and inflicts most dangerous, if not deadly wounds with his sharp and powerful tusks."

"Negroes, when stealing through the gloomy shades of the tropical forest, become sometimes aware of the proximity of one of these formidable Apes by the 
sudden disappearance of one of their companions, who is hoisted up into the tree, uttering perhaps a short choking cry. In a few minutes he falls to the ground a strangled corpse. The Gorilla, watching his opportunity, has let down his huge hind hand, seized the passing negro by the neck, with vice-like grip, has drawn him up to higher branches, and dropped him when his struggles had ceased."

\section{Order XII.-MAN.}

BIMANA.

"Two of far nobler shape, erect and tall, Godlike erect, with native honour clad, In naked majesty seemed lords of all; And worthy seem'd; for in their looks divine The image of their glorious Maker shone."

Paradise Lost.

Mutron, in these lines, has described one of the most striking external characteristics of Man : his erect gait. The zoologists point to the human hand as presenting another mark of distinction. In Man only can the thumb be applied with such precision and power to each of the fingers as to seize the most minute objects. So much superior is it to the anterior extremity in Monkeys, that Sir Charles Bell remarks,_- "We ought to define the hand as belonging exclusively to man." Of all animals, the term Bimana, or two-handed, is applicable to Man alone. He stands in the scale of the animal creation apart and unapproachable, gifted with 
dominion over the "beasts of the field, the fowl of the air, and the fish of the sea, and whatsoever passeth through the paths of the sea."

It is not intended in this little book to enter into the natural history of Man; but only to show the place he occupies in the classification of the animal kingdom, and the external peculiarities by which he is distinguished. Reference to his intellectual and moral faculties would here be out of place.

But ere I part with the youthful readers for whom this volume is intended, I would say to them, that if they have found it at times dull and unattractive, let them blame the author, and not the subject, and go forth and examine for themselves the happy tribes of the air, the earth, and the waters. Should they do so they will never find a "whole holiday" tedious, nor have cause to say that they feel dull or languid for want of something to do. The pursuits to which I would direct them give enjoyment to youth, relaxation to manhood, and occupation to age. They furnish pleasant thoughts and healthful exercise; and they teach us to read the volume of Nature with a constant reference to its great and beneficent AUTHOR,

"To us invisible, or dimly seen

In these his lowest works."

Note.-For fuller information on the Mammalia we would refer our young readers to a work published in 1860, entitled The Museum of Natural History, Mackenzie, Glasgow. From it we have copied, on a reduced scale, the three figures $230,231,232$. 

Prois25: 59

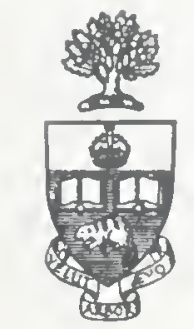

Library

$$
\text { of the }
$$

University of Toronto 


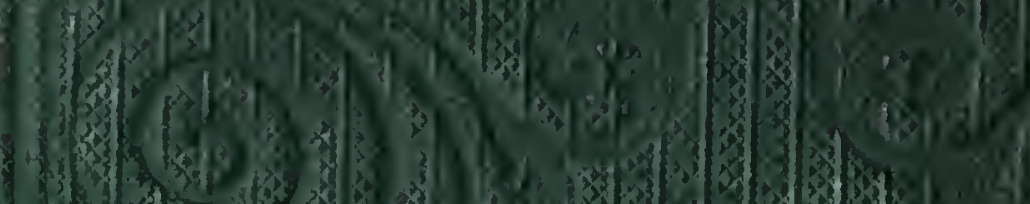

3.

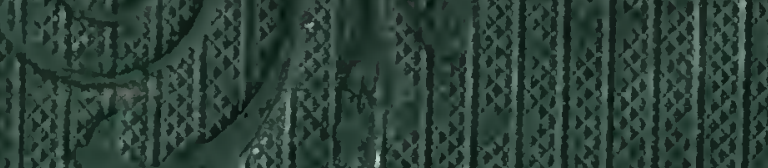

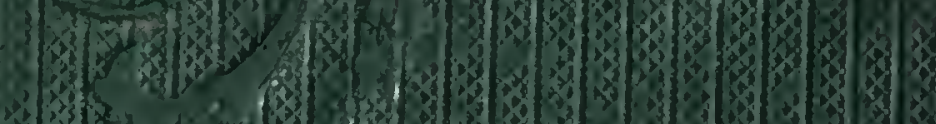

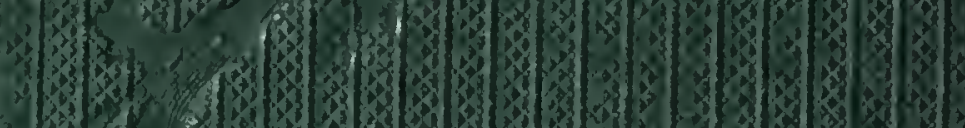

$3 \sqrt{13}$, 3

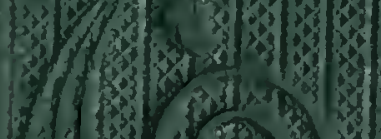

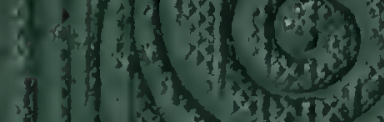

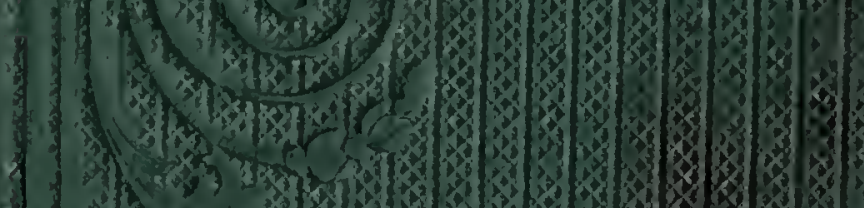

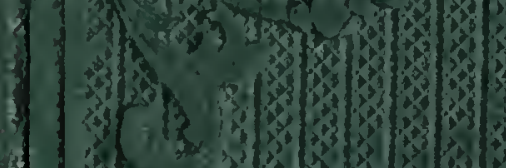

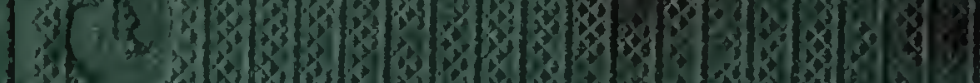

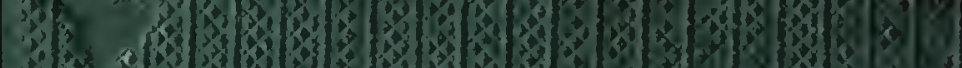

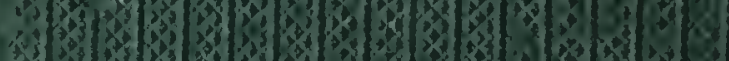

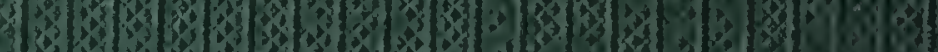

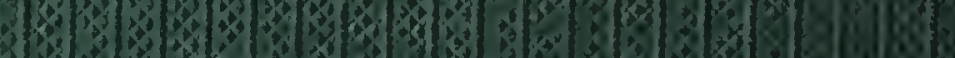

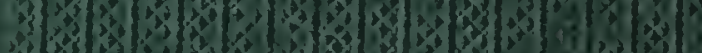

,

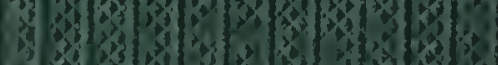

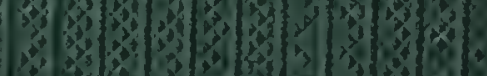

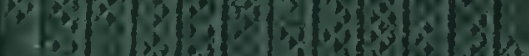

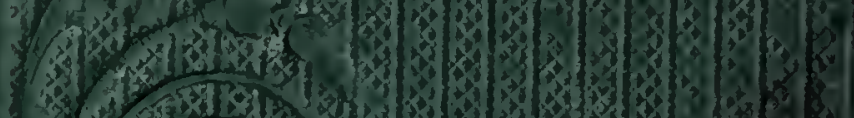

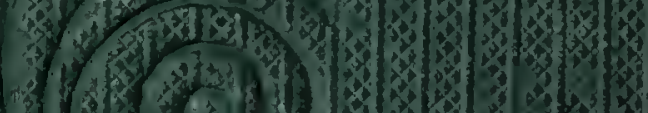

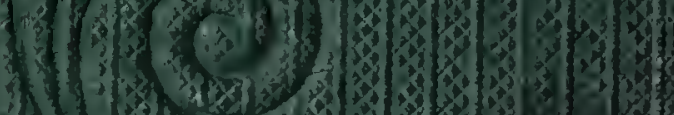

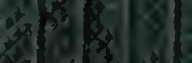

(n) $)(x+2)$

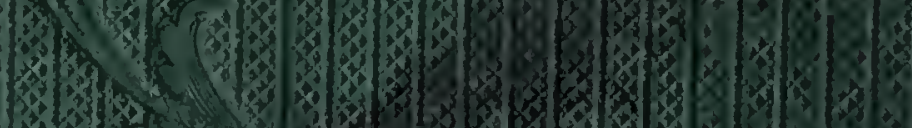

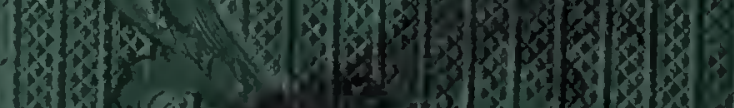

3 (n)

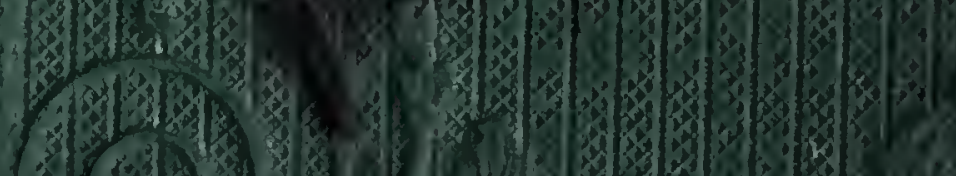

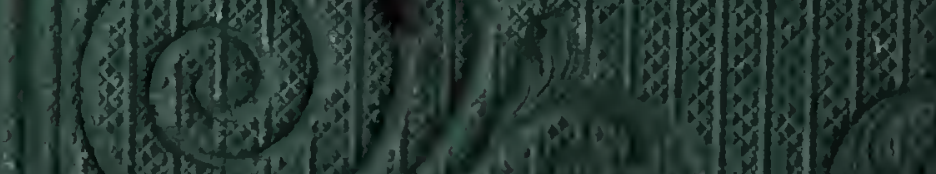

$3^{3}$ (h)

(1) 